\title{
Trender i idrettspsykologisk forskning i Skandinavia
}

Tommy Haugen og Rune Høigaard (red.)

CAPPELEN DAMM AKADEMISK 


\section{Trender i idrettspsykologisk forskning i Skandinavia}



Tommy Haugen og Rune Høigaard (red.)

Trender i

idrettspsykologisk

forskning i Skandinavia

CAPPELEN DAMM AKADEMISK 
(C) 2018 Frank E. Abrahamsen, Astrid Becker-Larsen, Martin Kjeøen Erikstad, Joar Gjerde, Rune Giske, Tommy Haugen, Kristoffer Henriksen, Jørgen Holmemo, Carsten Hvid Larsen, Rune Høigaard, Per-Mathias Høgmo, Harald S. Gaard, Kazuma Ishimatsu, Andreas Ivarsson, Bjørn Tore Johansen, Urban Johnson, Anders Meland, Yngvar Ommundsen, Anne Marte Pensgaard, Michael Sæther Reinboth, Knud Ryom, Kjetil M.U Salvesen, Sondre R. Solheim, Bård Erlend Solstad, Reinhard Stelter, Louise Kamuk Storm, Anthony Wagstaff, Bente Wold.

Dette verket omfattes av bestemmelsene i Lov om opphavsretten til åndsverk m.v. av 1961. Verket utgis Open Access under betingelsene i Creative Commons-lisensen CC-BY 4.0 (http://creativecommons.org/licenses/by/4.0/). Denne tillater tredjepart å kopiere, distribuere og spre verket $\mathrm{i}$ hvilket som helst medium eller format, og å remixe, endre, og bygge videre på materialet til et hvilket som helst formål, inkludert kommersielle, under betingelse av at korrekt kreditering og en lenke til lisensen er oppgitt, og at man indikerer om endringer er blitt gjort. Tredjepart kan gjøre dette på enhver rimelig måte, men uten at det kan forstås slik at lisensgiver bifaller tredjepart eller tredjeparts bruk av verket.

Boka er utgitt med støtte fra Universitetet i Agder.

ISBN PDF: 978-82-02-59690-3

ISBN EPUB: 978-82-02-60949-8

ISBN HTML: 978-82-02-60950-4

ISBN XML: 978-82-02-60951-1

DOI: https://doi.org/10.23865/noasp.39

Dette er en fagfellevurdert antologi.

Cover Design: Cappelen Damm AS

Cappelen Damm Akademisk/NOASP

www.noasp.no

noasp@cappelendamm.no 


\section{Innhold}

Forord Trender i idrettspsykologisk forskning i Skandinavia 7

Tommy Haugen \& Rune Høigaard Redaktører

Kapittel 1 Allvarliga idrottsskador hos svenska manliga akademifotbollsspelare: Är uppkomsten av dessa relaterade till upplevda stressymptom och samtalsklimatet med fotbollstränaren?

Urban Johnson \& Andreas Ivarsson

Kapittel 2 Med det danske U20 ishockeylandshold til VM:

Stress og genopladning under træningslejre og konkurrencer 29

Kristoffer Henriksen, Astrid Becker-Larsen \& Carsten Hvid Larsen

Kapittel 3 Mestrer jeg trenerrollen? Validitet og reliabilitet i en skala til måling av mestringstro $i$ et utvalg norske breddefotballtrenere. .47

Yngvar Ommundsen, Bård Erlend Solstad, Rune Høigaard \& Bente Wold

Kapittel 4 Profesjonelle fotballtreneres interaksjon med sine overordnede og assistenter: Bruk av orkestrering og mikropolitisk leseferdighet.

Jørgen Holmemo \& Frank Eirik Abrahamsen

Kapittel 5 Miljøets betydning i elitesport: Et holistisk økologisk case studie af det nationale træningscenter i badminton 103

Carsten Hvid Larsen, Louise Kamuk Storm \& Kristoffer Henriksen

Kapittel 6 Idrætspsykologi med et community psykologisk afsæt:

Erfaringer fra et socialt eksperiment i København, Danmark 121

Knud Ryom \& Reinhard Stelter

Kapittel 7 Hva sier de til seg selv? En kvasieksperimentell studie av triatlonutøveres selvsnakk under konkurranse.

Michael S. Reinboth, Tommy Haugen, Sondre R. Solheim \& Rune Høigaard

Kapittel 8 Felles mentale modeller i elitelagballspill: En kvalitativ analyse av spilleres opplevelse av medspillerkunnskap i fotball

Rune Giske, Harald Sylfest Gaard \& Joar Gjerde 
Kapittel 9 Sammenhengen mellom mindfulness og eksekutiv funksjon hos profesjonelle fotballspillere

Anders Meland, Per-Mathias Høgmo, Kazuma Ishimatsu,

Anthony Wagstaff \& Anne Marte Pensgaard

Kapittel 10 Når dommeren i fotball dømmer feil ... En videobasert analyse av straffesparksituasjoner i Tippeligaen der norske toppdommere og toppspillere har vurdert at dommerens avgjørelse er feil.

Bjørn Tore Johansen \& Martin K. Erikstad

Kapittel 11 Prinsipper ved test-retest-reliabilitet: Test av protokoll for maksimal innsats på sykkelrulle med ett minutts varighet .225

Tommy Haugen, Kjetil Marius Ulland Salvesen \& Rune Høigaard

Kapittel 12 Effekt av feedback på kollektiv mestringstro og sosial loffing i et sykkeleksperiment

Tommy Haugen, Kjetil Marius Ulland Salvesen \& Rune Høigaard

Om bidragsyterne. 257 


\title{
Trender i idrettspsykologisk forskning i Skandinavia
}

\author{
Tommy Haugen \& Rune Høigaard \\ Redaktører \\ Universitetet i Agder, Fakultet for helse- og idrettsvitenskap
}

\section{Om denne antologien}

Utgangspunktet for denne antologien var først og fremst et ønske om å illustrere dybden og mangfoldet i den idrettspsykologiske forskningen som gjøres av skandinaviske forskere. Idrett og fysisk aktivitet har en sentral plass i de skandinaviske landene, og vi har en lang og suksessrik historie av toppidrettsresultater, men også i forbindelse med barne- og ungdomsidrett, hvor man i stor grad fokuserer på aktivitet og bevegelsesglede. Både høgskoler og universiteter i de skandinaviske landene har vært sentrale kunnskapsutviklere innenfor idrettsvitenskap i over femti år. Dette gjelder også for faget idrettspsykologi. Selv om de ulike idrettspsykologiske fagmiljøene kanskje ikke er store sett i forhold til internasjonale aktører, er det høy kvalitet på den forskningen som gjøres, og det publiseres hyppig i anerkjente internasjonale tidsskrifter.

Vår grunnleggende idé med denne antologien er å formidle noe av den idrettspsykologiske forskningen som gjøres i Skandinavia, og samtidig gjøre det på et nordisk språk. Gjennom det skandinaviske dialektkontinuumet vil tekster på de tre språkene være gjensidig forståelige, og med det ha en teoretisk leserkrets på rundt 20 millioner mennesker. Ved å publisere forskningsbidragene i samlet form gjennom en Open Accessantologi vil forskningen bli mer tilgjengelig for andre fagfeller samt være til hjelp for idrettspsykologiske rådgivere og fagpersoner.

I forbindelse med planleggingen av en skandinavisk idrettspsykologisk antologi utfordret og inviterte vi sentrale og produktive forskere 
fra Sverige, Danmark og Norge til å bidra med originalt empirisk materiale. Det ble ikke lagt føringer for tematisk innhold eller spesielle metodiske tilnærminger. Den enkelte forsker eller forskergruppe kunneinnenfor rammen av forskningsfeltet idrettspsykologi - fritt utforme sitt vitenskapelige bidrag. Gjennom en omfattende fagfellevurdering ble til slutt tolv bidrag akseptert. Både tematisk innhold og forskningsmessige design og metoder har stor variasjon og gjenspeiler nok også den aktuelle idrettspsykologiske forskningen i Skandinavia: stor variasjon og bredde. Vi vil imidlertid presisere at antologien ikke fanger opp hele dette omfattende forskningsfeltet, men viser noen områder og trender som sentrale aktører er opptatt av. At hovedvekten av bidragene er fra norske forskere, er mer tilfeldig og reflekterer heller ikke noe styrkeforhold knyttet til idrettspsykologisk forskning. De ulike bidragene presenteres som selvstendige arbeid i artikkelform, og det er ikke gjort noe forsøk på tematisk organisering.

I kapittel én bidrar Urban Johnson og Andreas Ivarsson fra Högskolan i Halmstad med en artikkel hvor de undersøker om stressymptomer og samtaleklima (trener-utøver) er relatert til risiko for alvorlig idrettsskade blant unge mannlige akademifotballspillere. Studien finner en relasjon mellom opplevd kvalitet i kommunikasjonen med fotballtreneren og skaderisiko. Forfatterne diskuterer praktiske implikasjoner og peker på veien videre for fremtidig forskning.

Kapittel to er et bidrag fra Syddansk Universitet i Odense, hvor Kristoffer Henriksen, Astrid Becker-Larsen og Carsten Hvid Larsen sporer stress og restitusjon over tid i det danske U-20-landslaget i ishockey, gjennom treningsopphold og påfølgende VM. Forfatterne undersøker kilder til stress og restitusjon og samler empiri gjennom survey, intervjuer og dagbøker. Artikkelen presenterer og diskuterer organisatoriske, sosiale, personlige og sportslige kilder til optimal stress- og restitusjonsbalanse.

Et arbeid med forfattere fra Norges idrettshøgskole, Universitetet i Agder og Universitetet i Bergen utgjør kapittel tre, hvor Yngvar Ommundsen, Bård Erlend Solstad, Rune Høigaard og Bente Wold validerer en norsk versjon av Coaching Efficacy Scale. Forfatterne konkluderer med at skalaen er velegnet til undersøkelse av treneres 
mestringstro i barne- og ungdomsidrett, og etterlyser ytterligere validering før bruk i intervensjonsstudier.

Videre, i kapittel fire, undersøker Jørgen Holmemo og Frank Eirik Abrahamsen fra Norges idrettshøgskole bruk av orkestrering og mikropolitisk kompetanse i fotballtreneres interaksjon med sine overordnede og assistenter. Tre erfarne topptrenere intervjues, og funnene indikerer at ferdigheter innen orkestrering og mikropolitikk synes å være viktig i trenergjerningen. Forfatterne presenterer implikasjoner for trenere og trenerutdannere, og de foreslår retninger for fremtidig forskning på feltet.

Kapittel fem er bidrag nummer to fra miljøet ved Syddansk Universitet i Odense, hvor Carsten Hvid Larsen, Louise Kamuk Storm og Kristoffer Henriksen presenterer en holistisk økologisk case-studie av det nasjonale treningssenteret for badminton. Studiens funn støtter tidligere forskning på feltet, samtidig som det bidrar med ny kunnskap gjennom et unikt innblikk i miljøets betydning for eliteutøveres utvikling.

Kapittel seks fra Knud Ryom og Reinhard Stelter fra henholdsvis Aarhus Universitet og Københavns Universitet presenterer og diskuterer bruken av såkalt community-psykologisk tilnærming når en jobber med idrettspsykologi i sosialt utsatte bydeler. Arbeidet gir innblikk i utradisjonell forskningsmetodikk og diskuterer betydningen av en tydeligere økologisk tenkning og vektlegging av sosial kontekst innenfor rammene av idrettspsykologi.

Michael Reinboth fra Universitetet i Sørøst-Norge bidrar sammen med Tommy Haugen, Sondre R. Solheim og Rune Høigaard fra Universitetet i Agder med kapittel syv. Artikkelen er en kvasieksperimentell studie som kartlegger og sammenligner elite- og klubbutøveres bruk av selvsnakk i løpet av en triatlonkonkurranse. Studien presenterer utøveres selvsnakk underveis i selve konkurransen, og diskuterer både styrker og svakheter knyttet til design og funn.

Kapittel åtte er et bidrag fra Rune Giske (Universitetet i Stavanger), Harald Sylfest Gaard (Universitetet i Agder) og Joar Gjerde (Universitetet i Stavanger), hvor forfatterne undersøker elitespilleres opplevelse av medspillerkunnskap i fotball og håndball. Analyser av kvalitative intervjuer understøtter betydningen av medspillerkunnskap på elitenivå, og 
at trenere og spillere bør ha en tydelig strategi for hvordan denne kunnskapen kan fremmes.

I kapittel ni undersøker Anders Meland (Flymedisinsk institutt), Per-Mathias Høgmo (Universitetet i Tromsø), Kazuma Ishimatsu (Jikei Institute, Osaka), Anthony Wagstaff (Flymedisinsk institutt) og Anne Marte Pensgaard (Norges idrettshøgskole) sammenhengen mellom mindfulness og eksekutiv funksjon hos profesjonelle fotballspillere. Studien indikerer at de ulike mindfulness-fasettene er ulikt assosiert med eksekutiv funksjon, og forfatterne peker på at fremtidige studier må søke å maksimere fordelene og minimere ulempene ved mindfulness-intervensjoner.

Kapittel ti er et bidrag fra Bjørn Tore Johansen og Martin K. Erikstad fra Universitetet i Agder. Gjennom videoanalyse undersøker forfatterne hva som karakteriserer straffesparksituasjoner i norsk toppfotball hvor et ekspertpanel har vurdert dommeravgjørelsen som gal. Studien gir et innblikk i kompleksiteten rundt dommergjerningen og dommerens avgjørelser på elitenivå. Studiens funn blir diskutert i lys av teori om håndtering av feil og sosialt press.

Kapittel elleve er skrevet av Tommy Haugen, Kjetil M.U. Salvesen og Rune Høigaard fra Universitetet i Agder og tar for seg grunnleggende prinsipper ved test-retest-reliabilitet, samtidig som det gjennomføres en reliabilitetstest av en protokoll for maksimal innsats på sykkelrulle. Protokollen viser tilfredsstillende test-retest-reliabilitet, og den aktuelle protokollen brukes i et eksperiment presentert i kapittel tolv fra de samme forfatterne. Eksperimentet undersøker effekten av positiv og negativ feedback på kollektiv mestringstro og sosial loffing i en lagkonkurranse. Studien viser til effekt på kollektiv mestringstro, men ingen tegn til effekt på graden av sosial loffing.

Et kjerneelement i kunnskapsutvikling er åpen dialog og tett samarbeid. Vi utfordrer fagfeller, og oss selv, til å bygge videre på et solid fundament og videreutvikle den idrettspsykologiske forskningen i Skandinavia, blant annet ved å knytte enda tettere bånd på tvers av landegrenser og institusjoner. Til slutt ønsker vi å takke alle bidragsytere for deres vilje til å delta i arbeidet med antologien, og gjennom deres innsats håper vi å kunne presentere varierte stemmer og perspektiver 
innen idrettspsykologisk forskning i Skandinavia. En stor takk rettes også til de mange anonyme fagfellene som har vurdert bidragene gjennom flere runder.

God lesning!

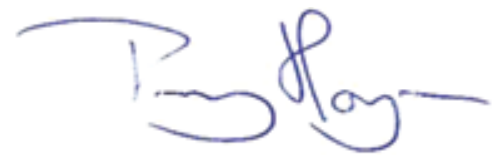

Tommy Haugen

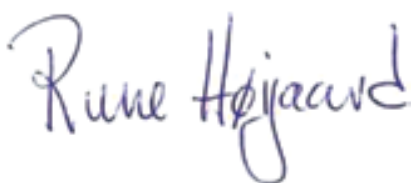

Rune Høigaard 



\title{
Allvarliga idrottsskador hos svenska manliga akademifotbollsspelare
}

\section{Är uppkomsten av dessa relaterade till upplevda stressymptom och samtalsklimatet med fotbollstränaren?}

\author{
Urban Johnson * \& Andreas Ivarsson
}

Högskolan i Halmstad, Centrum för forskning om välfärd, hälsa och idrott

\begin{abstract}
Sammanfattning: Studier visar att 50\% av idrottande ungdomar skadar sig minst en gång per säsong och att dessa medför såväl psykosocialt lidande som höga kostnader för samhället. Två psykosociala faktorer som kan påverka risken för skada är stress samt relationen med tränare. Studiens syfte var att undersöka om stressymptom samt det upplevda samtalsklimatet i relation till fotbollstränaren var relaterade till risken för allvarliga idrottsskador (frånvaro från full träning under minst en månad). Totalt deltog 89 manliga akademifotbollsspelare i Sverige i åldrarna 13-16 år i studien. Under det år som studien genomfördes rapporterade 27 spelare att de drabbades av en allvarlig skada. Resultatet från en logistisk regressionsanalys visade att upplevda stressymptom inte var statistiskt signifikant relaterade till risken att råka ut för allvarliga skada. Dock visade resultatet att upplevelsen av ett bra samtalsklimat i relation till fotbollstränaren var relaterat till en minskad risk för att råka ut för allvarlig skada.
\end{abstract}

Nyckelord: skada, kommunikation, stressymptom, akademifotbollsspelare, fotboll, psykologi.

\begin{abstract}
Studies shows that about $50 \%$ of youth sport athletes experience at least one injury during each athletic season and this brings psychosocial distress and elevated costs for society. Two psychosocial factors that might be associated with the risk of becoming injured are stress and the climate of dialogue (communication) with the coach. The purpose was to study if stress-symptoms and communication with soccer coach was related to the occurrence of severe injuries (absent from training for at least one month). In total 89 male players in Swedish youth soccer academies at age 13-16 years participated. During the study period, 27 players experienced severe injuries. The result showed that perceived stress-symptom was not statistically significant related to injury occurrence. Perceived high quality in the communication with soccer coaches was related to reduce injury risk.
\end{abstract}

Keywords: injury, sport, communication, stress symptoms, academy player, soccer, psychology

\footnotetext{
*Korresponerande författare: Urban Johnson, Centrum för forskning om välfärd, hälsa och idrott, Högskolan i Halmstad, Sverige, Box 823, S-301 18 Halmstad, Sverige, Telefon: (46) 3516710o, Fax: (46) 35167264, e-mail: urban.johnson@hh.se
}

Sitering av denne artikkelen: Johnson, U. \& Ivarsson, A. (2018). Allvarliga idrottsskador hos svenska manliga akademifotbollsspelare: Är uppkomsten av dessa relaterade till upplevda stressymptom och samtalsklimatet med fotbollstränaren? I T. Haugen \& R. Høigaard (Red). Trender i idrettspsykologisk forskning i Skandinavia (Kap. 1, s. 13-28). Oslo: Cappelen Damm Akademisk. DOI: https://doi.org/10.23865/noasp.39.ch1

Lisens CC-BY 4.0 


\section{Introduktion}

Skador är ett vanligt fenomen som de flesta idrottare upplever under sin karriär. Mer specifikt rapporterade Patel och Nelson (2000) att 50\% av idrottande ungdomar skadar sig minst en gång per säsong. Av dessa skador klassificeras ungefär $2 / 3$ som lättare (d.v.s. mindre än en vecka rehabilitering) och övriga i varierande grad som medelsvåra/allvarliga. Att drabbas av en idrottsskada, framförallt av allvarligare karaktär, har visat sig vara associerat med ett antal negativa konsekvenser. Ett exempel på en negativ konsekvens är att idrottsskador är en vanlig orsak till avslut från idrotten både bland vuxna (Drawer \& Fuller, 2001) och barnoch ungdomar (Crane \& Temple, 2015). Skador har även visat sig vara förknippade med negativa kognitiva och känslomässiga reaktioner (t.ex. upplevelse av smärta, känsla av förlust, sorg, ilska, rädsla) som i sin tur kan ha negativ inverkan på idrottarens välbefinnande (se t.ex. Hagger, Chatzisarantis, Griffin, \& Thatcher, 2005; Wiese-Bjornstal, 2010). Även på samhällsnivå är idrottsskador associerade med negativa konsekvenser då behandlingen av idrottsskador är förknippad med stora kostnader för hälso- och sjukvårdssystemet, inte minst i samband med barn- och ungdomsidrotten (Frisch, Croisier, Urhausen, Seil, \& Theisen, 2009). I Sverige har Myndigheten för samhällsskydd och beredskap (2010) uppskattat att kostnaden för behandling av idrottskador är 3-4 Miljarder SEK per år.

Givet de negativa konsekvenser, på både individ- och samhällsnivå, som kan vara associerade med idrottsskador är det av relevans att undersöka vilka faktorer som kan öka risken för att råka ut för en idrottsskada (Bahr, 2016). Denna typ av undersökning är speciellt angelägen att genomföra bland idrottande barn och ungdomar då dessa traditionellt har fått mindre uppmärksamhet inom forskningen, men framförallt därför att tidiga inträffade idrottsskador i många fall leder till tidigt avslut från föreningsidrotten (Wiese-Bjornstal, 2003). Tidigare studier kring riskfaktorer för idrottsskador har framförallt fokuserat på demografiska, fysiologiska samt biomekaniska faktorer (Almeida, Olmedilla, Rubio, \& Palou, 2014). Under de senaste åren har även psykologiska riskfaktorer för idrottsskador identifierats (Johnson, Tranaeus, \& Ivarsson, 2014). 
Med bakgrund i ovanstående aspekter är det därför av intresse att närmare studera om psykosociala faktorer kan öka risken för idrottsskador hos unga fotbollsspelare.

I samband med att forskare försökt att identifiera psykologiska riskfaktorer för idrottsskador har flera teoretiska modeller utvecklats (se t.ex. Meeuwisse, Tyreman, Hagel, \& Emery, 2007). Den kanske mest citerade och använda modellen är Williams och Andersens (1998) "stress- och skademodell”. I denna modell föreslås att en potentiellt stressfylld situation kommer att generera en stressrespons. Stressresponsen föreslås bestå av fysiologiska (t.ex. muskelanspänning) samt psykologiska (t.ex. försämrad uppmärksamhet) komponenter. En stark stressrespons är associerad med en ökad risk för att råka ut för en idrottsskada. Stressresponsens intensitet påverkas, enligt modellen, av hur idrottaren uppfattar den potentiellt stressfyllda situationen. Tre centrala psykologiska kategorier är i modellen föreslagna att påverka hur en idrottare uppfattar situationen som denne befinner sig i. Dessa tre kategorier är: (a) personlighet (t.ex. ångest, perfektionism, Typ A beteende); (b) tidigare stresshistorik (t.ex. omfattande stressfyllda händelser i livet, dagliga och frekventa stressmoment, tidigare skadehistorik) och (c) copingstrategier/resurser (t.ex. psykologiska bemästringsstrategier, socialt stöd). Eftersom dessa faktorer kan påverka intensiteten i stressresponsen föreslås de därför också att indirekt kunna öka eller minska risken för att en skada ska inträffa.

Den kategori av psykologiska riskfaktorer för idrottsskada som generellt fått starkast stöd i forskningen är tidigare stresshistorik (Ivarsson, Johnson, Andersen, Tranaeus, Stenling, \& Lindwall, 2017). Mer specifikt har flertalet studier funnit att höga nivåer av upplevd stress ökar risken för idrottsskada (t.ex. Ivarsson, Johnson, \& Podlog, 2013; Johnson \& Ivarsson, 2011). Exempelvis har studier visat att negativa livshändelser är relaterade till en försämrad koncentrationsförmåga, vilket i sin tur kan öka risken för skada (Rogers \& Landers, 2005).

Även om Williams och Andersens (1998) modell har använts frekvent och påvisats hålla i relation till prediktion av idrottsskador (se Ivarsson et al., 2017 för resultat från modelltestning) har ett antal tillkortakommanden diskuterats (se t.ex. Appaneal \& Perna, 2014). Ett av dessa tillkortakommanden är att modellen inte tar hänsyn till sociokulturella 
faktorer (t.ex. organisationsstress, relationer, kommunikationsmönster etc.) som alla kan påverka risken för idrottsskador (Wiese-Bjornstal, 2010). Därför har relativt sparsamt med forskning studerat hur idrottsledares (tränares) kommunikation med grupp/spelare kan påverka skadeuppkomsten. Denna relation är relevant att studera ur ett idrottsskadeperspektiv då tidigare studier visat att en bristfällig interaktion med tränaren dels kan öka risken för att en spelare fysiskt deltar i aktiviteten trots att denne upplever smärta (Roderick, Waddington, \& Parker, 200o) dels även öka risken för utmattnings- samt utbrändhetssymptom (Eklund \& Defreese, 2017). Både att idrotta med hög smärta och att uppleva utmattnings- och/eller utbrändhetssymptom i samband med fysisk aktivitet kan öka risken för skada (Soligard et al., 2016). Emellertid har studier även föreslagit hur ett bra samtalsklimat kan minska skaderisken (Ivarsson \& Andersen, 2017). Mer specifikt kan en god interaktion med t.ex. en tränare generera stressreducerande effekt (Umberson \& Montez, 2010), vilket i sin tur kan vara negativt relaterat till skadeuppkomst (Ivarsson et al., 2017). Men för att erhålla positiva effekter är det fördelaktigt att relationen mellan tränaren och spelaren bygger på empati och välvilja (Andersen \& Ivarsson, 2016; Siegel, 2010). Skapandet av ett klimat inom framförallt ungdomsidrotten där sådana förhållanden utvecklas mellan tränare/ledare och idrottare är därför viktiga att utveckla för att undvika ökade stresspåslag/bristande koncentrationsförmåga och därmed minskad risk för idrottsskador (jfr med stress- och skademodellen).

Med tanke på att idrottsskador innebär en omfattande fysiologisk och psykosocial belastning, inte minst för elitsatsande unga fotbollsspelare, och att skador medför stora samhällskostnader, är det centralt att närmare förstå psykosociala mekanismer som kan öka risken för skadeuppkomsten. Givet att både relationella samt psykologiska faktorer är föreslagna att påverka risken för skador, är fokus i denna studie att inkludera båda dessa aspekter.

Syftet med studien var därför att undersöka psykologiska stressymptom och om det upplevda samtalsklimatet i relation till fotbollstränaren var relaterade till risken för allvarliga idrottsskador hos manliga svenska akademifotbollsspelare. 


\section{Metod}

\section{Deltagare}

I urvalet ingick 93 akademifotbollsspelare i Sverige. Av dessa var det 4 spelare som inte hade rapporterat in kompletta data vid båda tidpunkterna (4.3\%). Dessa spelare var därför exkluderade från analyserna. Det slutgiltiga urvalet bestod därför av 89 manliga akademifotbollsspelare i åldrarna 13-16 år $(M=14.27, S D=0.98)$. Alla spelarna tillhörde svenska fotbollsakademier. Vid starten för studien rapporterade 24 spelare (27\%) att de under föregående år varit borta från fotbollen under minst en månad på grund av en allvarlig skada.

\section{Instrument}

\section{Demografiska data}

Bakgrundsfrågor gällande ålder samt träningsmängd samlades in vid det första mättillfället.

\section{Allvarliga skador}

Både vid starten av studien och ett år senare ombads spelarna att svara på frågeställningen "Har du under föregående säsong varit borta från spel minst 1 månad på grund av en skada?". De två svarsalternativ som fanns tillgängliga var "Ja" respektive "Nej”. En skada som håller idrottaren borta från full aktivitet minst 1 månad klassificeras som en allvarlig skada (Fuller et al., 2006).

\section{Stressymptom}

Frågeformuläret "General Health Questionnaire-12" (Goldberg et al., 1997) användes för att mäta stressymptom. Svaren angavs på en 4-gradig Likertskala som spänner mellan o (stämmer inte alls) till 3 (stämmer helt och hållet). Vid kodning av svaren följde vi Goldberg et al.s (1997) rekommendationer och använde den traditionella kodnyckeln GHQ-12 (o-0-1-1). Baserat på kodnyckeln kunde varje spelare få en totalsumma mellan o och 12 där höga nummer indikerade höga nivåer av stressymptom. 


\section{Kommunikation}

Delskalan "kommunikation" från frågeformuläret "Talent Development Environment Questionnaire" (TDEQ; Martindale et al., 2010) användes för att mäta spelarnas upplevelse av kvalitén på samtalsklimatet med tränaren. Delskalan består av sju frågeställningar och besvaras på en 6-gradig Likertskala som spänner mellan 1 (håller inte alls med) till 6 (håller med helt och hållet). Exempel på frågeställningar är: "Tillsammans med min tränare sätter jag upp mål som är kopplade till min personliga utveckling" samt "Jag och min tränare försöker förutse vad som blir min nästa stora utmaning."

\section{Procedur}

Studien är godkänd vid den regionala etiknämnden i Lund. I början av säsongen kontaktades tränare verksamma vid en av tre fotbollsakademier i Sverige, via telefon, för att undersöka intresset av att delta i studien. Vid denna telefonkontakt bestämdes tid för ett möte där tränarna fick information om syftet med studien. Om tränarna samtyckte till deltagande arrangerades en tid för datainsamling hos respektive lag. I god tid före det datum då datainsamlingen för respektive lag planerades fick alla föräldrar till spelarna i respektive lag ett mailutskick där de fick information kring studien samt att de, genom att sända ett mail till forskarna, kunde förhindra att deras barn deltog i studien. Vid datainsamlingstillfället informerades spelarna om studiens syfte samt etiska överväganden både skriftligt och muntligt från den medlem ur forskningsgruppen som deltog vid respektive tillfälle. De spelarna som samtyckte till att delta i studien ombads vid detta tillfälle fylla i frågeformulären. Datainsamlingen genomfördes via pappersenkäter. Ett år efter det första datainsamlingstillfället ombads spelarna att på nytt indikera ifall de under föregående säsong råkat ut för en allvarlig idrottsskada. Även vid denna tidpunkt användes pappersenkät.

\section{Dataanalys}

I det första steget av dataanalysen beräknade vi beskrivande statistik. Detta innebar att vi, för varje variabel som var av intresse för syftet, beräknade medelvärde och standardavvikelse. Vidare genomfördes korre- 
lationsanalyser för att analysera sambandet mellan de kontinuerliga variablerna som ingick i studien. För att undersöka om det fanns någon statistiskt signifikant skillnad i stressymptom eller upplevelsen av samtalsklimatet mellan de spelare som rapporterade att de haft en allvarlig skada säsongen innan studien startade och de spelare som inte rapporterade att de haft en allvarlig skada föregående säsong genomfördes två oberoende $t$-test.

I det andra steget genomfördes två logistiska regressionsanalyser. I den första regressionsanalysen inkluderade vi de två oberoende variablerna stressymptom och kommunikation samt den beroende variabeln allvarlig skada som inrapporterats under studieperioden. I den andra regressionsanalysen inkluderade vi, förutom de variabler som fanns med i den första logistiska regressionsanalysen, även de två oberoende variablerna tidigare allvarliga skador samt timmar träning/vecka. Anledningen till att vi valde att inkludera dessa två variabler är att tidigare forskning har föreslagit att både tidigare skador och antal timmar träning är riskfaktorer för nya skador (Hägglund, Waldén, Til, \& Pruna, 2010; Steffen, Pensgaard, \& Bahr, 2009). Vi ville därför statistiskt kontrollera för dessa i vår analys. För att utvärdera vilken av de två regressionsanalyserna som hade bäst anpassning till insamlade data använde vi oss av -2 Log Likelihood (-2 LL) -värdet. Ett lägre -2 LL-värde innebär att den statistiska modellen passar data bättre jämfört med en statistisk modell med ett högre -2 LL-värde. Vi valde därför att diskutera resultatet från den av de två regressionsanalyser som hade det lägsta -2 LL värdet.

För alla analyser ansågs $p<0.05$ indikera att resultatet var statistiskt signifikant. För att bestämma storleken på effekten för samband i korrelationsanalysen beräknades Pearsons korrelationskoefficient $r$. Som effektstorlekar för skillnaderna i de två oberoende t-testen beräknandes Cohens $d$. Effektstorlekarna som beräknades för den logistiska regressionsanalysen var Odds Ratios (OR).

\section{Resultat}

\section{Deskriptiva data}

Av de deltagande spelarna rapporterade $29 \%(n=27)$ att de hade råkat ut för minst en allvarlig skada under studieperioden. Vidare rapporterade 
spelarna, i genomsnitt, låga nivåer av stressymptom $(M=0.97, S D=1.34)$. Det fanns ett svagt negativt, men inte statistiskt signifikant, samband mellan stressymptom och den upplevda kvalitén av samtalsklimatet mellan spelaren och fotbollstränaren $(r=-.15, p=.17)$. Det fanns en statistiskt signifikant skillnad i upplevd kvalité av samtalsklimatet med fotbollstränaren mellan de spelare som hade haft en allvarlig skada under förgående säsong (d.v.s. säsongen innan första datainsamlingen genomfördes) och dem som inte hade haft en sådan skada $(t(1,87)=-2.31$, $p=0.02$, Cohens $d=-0.59$ ). Närmare bestämt skattade spelare som haft en allvarlig skada högre värden på kvalitén vid samtalsklimatet mellan spelaren och tränaren i jämförelse med spelare som inte varit skadade under föregående säsong. Det fanns ingen statistiskt signifikant skillnad i stressymptom mellan de spelare som haft en allvarlig skada säsongen innan studien påbörjades och dem som inte varit allvarligt skadade $(t(1,87)=-0.01, p=.92$, Cohe's $d=-0.02)$. För mer beskrivande statistiskt se Tabell 1 .

Tabell 1. Medelvärde och standardavvikelse för studiens variabler.

\begin{tabular}{|l|c|c|c|}
\hline Variabel & M (SD) & Potentiella värden & Faktiska värden \\
\hline Ålder & $14.27(0.98)$ & NA & $13-16$ \\
\hline Stressymptom & $0.98(1.34)$ & $0-12$ & $0-7$ \\
\hline Antal träningstimmar/vecka & $8.08(3.30)$ & NA & $3-24$ \\
\hline Kommunikation & $4.13(1.08)$ & $1-6$ & $1-6$ \\
\hline
\end{tabular}

\section{Logistisk regressionsanalys}

Resultatet från den logistiska regressionsanalysen visade att den modell där vi kontrollerade för tidigare allvarliga skador samt träningstid passade data bättre $(-2 L L=90.75)$ i jämförelse med den modell där de två variablerna inte var inkluderade $(-2 L L=109.35)$. Baserat på resultatet från modelltestningsproceduren valde vi därför att diskutera den modell som visade bäst anpassning till data. I den valda modellen kunde de inkluderade prediktorvariablerna (d.v.s. kvalitén av kommunikation med fotbollstränarna, stressymptom, tidigare allvarliga skador, träningstid) klassificera $71.9 \%$ av deltagarna i rätt kategori 
(ej skada vs. skada). Resultatet visade att ett upplevt bra samtalsklimat mellan spelare och fotbollstränaren minskar risken för skada under studieperioden $(O R=0.54,95 \% C I=[0.32,0.90])$. Vidare visade resultatet att de spelare som tidigare haft en allvarlig skada löpte större risk för att råka ut för en allvarlig skada under studieperioden $(O R=10.61,95 \%$ $C I[3.09,36.38])$. Varken stressymptom $(O R=0.95,95 \% C I[0.66,1.39])$ eller träningstid $(O R=1.0895 \% C I[0.92,1.26])$ hade någon statistiskt signifikant effekt på risken för att råka ut för en allvarlig skada under studieperioden.

\section{Diskussion}

Syftet med studien var att undersöka om psykologiska stressymptom och om det upplevda samtalsklimatet i relation till fotbollstränaren var relaterade till risken för allvarliga idrottsskador hos manliga svenska akademifotbollsspelare. De sammanfattande resultaten visar att upplevda stressymptom inte var relaterade till risken att råka ut för allvarliga idrottsskador bland akademifotbollsspelare. Emellertid visade resultaten att upplevelsen av ett bra samtalsklimat med fotbollstränaren var relaterat till en minskad risk för att råka ut för allvarliga skador.

Med utgångspunkt från Williams och Andersens "stress- och skademodell" (1998) och tidigare presenterad forskning (t.ex. Ivarsson et al., 2017) var vårt antagande att det skulle finnas ett positivt samband mellan upplevda stressympton och risken för allvarliga skador bland akademifotbollsspelare. Resultatet från studien bekräftade inte detta antagande. En möjlig förklaring till resultatet kan vara att spelarna generellt rapporterade låga värden av stressymptom vilket, i sin tur, kan innebära att de inte påverkades av några starkare stressresponser under idrottsutövande. En annan tänkbar förklaring till de låga värdena av upplevda stressymptom bland akademifotbollsspelarna kan vara att deltagande i idrottsaktiviteter är relaterat till ökade nivåer av hälsa och välmående. Vid ett kontinuerligt idrottsutövande får idrottande ungdomar möjlighet att umgås med både kompisar och tränare samt känna tillhörighet till ett lag (Jewett et al., 2014). Både att ha möjlighet till social interaktion samt känna tillhörighet är grundläggande sociala behov som har ett positivt 
samband med upplevd hälsa (Baumeister \& Leary, 1995; Umberson \& Montez, 2010).

Resultatet visade också att upplevelsen av ett bra samtalsklimat med fotbollstränaren var relaterat till lägre risk för allvarliga idrottsskador hos manliga svenska akademifotbollsspelare. Detta resultat är i linje med den relativt sparsamma forskning som finns presenterad kring detta forskningsområde och som har påvisat att ett sämre samtalsklimat bland annat kan vara relaterat till ökad skadeuppkomst (Roderick et al., 2000; Tranaeus, Johnson, Engström, Skillgate, \& Werner, 2014). Inom den idrottssociologiska litteraturen diskuteras bland annat begreppet riskkultur i samband med tävlingsidrott. När idrottare för första gången kommer i kontakt med idrotten börjar de skolas in i en kultur kännetecknad av bestämda värderingar, kommunikationsmönster, normer, roller och förväntningar. Idrottarna lär sig det som har kallats "idrottsetik" av tränare, lagkamrater, föräldrar och media och internaliserar ofta detta värdesystem. Enligt Hughes och Coakley (1991) förmedlar den här etiken kriterier för vem som är "riktiga idrottare". "Riktiga idrottare" är sådana som gör uppoffringar för sin idrott, anstränger sig för att bli framgångsrika inom idrott, accepterar risker, fortsätter spela trots smärta och vägrar "att acceptera sina begränsningar". Idrottare som upplever att de kan prata med tränaren kring aspekter som rör dessa förväntningar och normer samt upplever att tränaren lyssnar och är intresserad av deras upplevda psykiska såväl som fysiska välbefinnande är generellt exponerade för en mindre risk för att skada sig trots negativa kontextuella aspekter som nämnts ovan (Roderick et al., 200o). Eftersom tränaren har makt över idrottarnas speltid och ställning i laget, och i samband med detta kan tvinga spelare att riskera sin hälsa genom att spela (Nixon, 1992), förefaller det vara särskilt viktigt med en god kommunikation i relation till skadeutveckling. En ytterligare förklaring till varför ett bra samtalsklimat med tränaren kan minska risken för skada är att bra relationer (t.ex. mellan tränare och spelare) är relaterat till en minskad risk för stress (Andersen \& Ivarsson, 2016), vilket i sin tur minskar risken för skada (Ivarsson et al., 2017).

Resultaten från studien visar också att de spelare som tidigare haft en allvarlig skada löpte större risk att råka ut för en allvarlig skada under studieperioden jämfört med de som under föregående säsong inte varit 
exponerade för allvarlig skada. Liknande resultat har tidigare rapporterats i snarlika populationer (Steffen et al., 2009). En av anledningarna till detta positiva samband är att många av de skador som inträffar i ungdomsfotboll är återfallsskador (Steffen et al., 2009). Ett ytterligare resultat som framkom var att spelare som haft en skada säsongen innan första datainsamlingen genomfördes skattade högre värden på kvalitén vid samtalsklimatet mellan spelaren och tränaren i jämförelse med spelare som inte varit skadade under den tidigare säsongen. En möjlig förklaring till detta resultat kan vara att en spelare ges mer individuell uppmärksamhet då denne är skadad än om han är i full träning. Fortsatt forskning krävs dock för att säkerställa detta resultat.

\section{Metodologiska överväganden}

Baserat på vald forskningsdesign och procedur återfinns några begränsningar som bör uppmärksammas. En första potentiell begränsning handlar om det relativt låga antalet rapporterade och allvarliga skador under studieperioden $(n=27)$. Detta begränsade urval gör att resultatens generaliserbarhet möjligen minskar. Å andra sidan överensstämmer skaderapporteringen med tidigare identifierad skadestatistik för idrottande ungdomar (Patel \& Nelson, 200o) vilket stärker studiens validitet.

En annan potentiell begränsning har att göra med trovärdigheten vid självrapportering av skador. För att minska risken för problematik vid rapportering (t.ex. problem att minnas frånvaro vid mindre skador) av skador beslutade forskarna att enbart be spelarna rapportera allvarliga skador. Detta innebär att vi inte har någon information om lättare skador (rehabiliteringstid under 1 månad) som kan ha inträffat under studiens genomförande. Givet att allvarliga skador troligtvis har störst negativ påverkan på idrottarens välbefinnande är det dock ett meningsfullt urval av skador. Flera studier har kritiskt diskuterat trovärdigheten vid självrapportering av idrottsskador, speciellt när dessa inträffat vid tidsmässigt utsträckta perioder (se t.ex. Gabbe, Finch, Bennell, \& Wajswelner, 2004).

En påtaglig metodologisk förtjänst med studiens resultat är den potential som denna ger att vidareutveckla Williams och Andersens "stressoch skademodell" (1998) med kompletterande kunskap kring vikten av 
att inkludera kontextuella faktorer, t.ex. riskkultur och dess relation till upplevd kvalitativ kontakt med ledarteamet, som sannolikt påverkar skadeuppkomsten inom ungdomsidrotten.

\section{Praktiska implikationer}

Studiens resultat tyder på att fotbollstränare har en viktig funktion i det skadeförebyggande arbetet för ungdomar i fotbollsakademier. I detta sammanhang är det därför viktigt att uppmuntra tränare att säkerställa att de etablerar bra samtalsklimat med sina spelare. För att främja ett bra samtalsklimat är det viktigt att tränarna först reflekterar över hur de beter sig i olika situationer och varför de beter sig på detta speciella sätt (Allan, Vierimaa, Gainforth, \& Coté, 2017). Efter reflektioner kring deras faktiska beteenden är det betydelsefullt för tränaren att tänka igenom hur detta beteende passar med dennes tankar och normer för att skapa en konstruktiv och icke dömande kommunikation, och därmed minska den potentiella skaderisken i samband med fotbollspelandet. Vid en sådan reflektion kan det också vara till nytta för tränaren att formulera sin ledarfilosofi i relation till de beteenden som manifesterar dennes filosofi (se också Johnson \& Ivarsson, 2018).

\section{Framtida forskning}

I Sverige har projektet "Knäkontroll", initierat av bl.a. Svenska fotbollförbundet, generellt lett till färre idrottsrelaterade skador inom ungdoms- och seniorfotbollen (Waldén, Atroshi, Magnusson, Wagner, \& Hägglund, 2012). Detta preventionsprogram är lovvärt men har i marginell utsträckning applicerats ur ett biopsykosocialt perspektiv, d.v.s. kombinerade forskningsinsatser från medicinare, beteendevetare och andra angränsande ämnesdiscipliner. Ett förslag på framtida forskningsstrategi är därför att utgå från multidisciplinära forskningsteam för att beforska hur ett preventionsprogram som baseras både på fysiologiska och neuromuskulära övningar samt ledarskapsutbildning med fokus på interpersonella relationer kan minska risken för idrottsskador bland unga fotbollsspelare. Detta upplägg kan förslagsvis utgå från en mixad 
metod, t.ex.via en beskrivande och sekventiell design (Sparkes, 2015), där kvalitativa resultat används för att underlätta och expandera initialt identifierade kvantitativa resultat med målet att på sikt minska andelen (allvarliga) skador bland fotbollsspelande ungdomar.

\section{Referenser}

Allan, V., Vierimaa, M., Gainforth, H.L., \& Coté, J. (2017). The use of behavior change theories and techniques in research-informed coach development programmes: a systematic review. International Review of Sport and Exercise Psychology. Advances online publication, DOI: 10.1080/1750984X.2017.1286514

Almeida, P.L., Olmedilla, A., Rubio, V.J., \& Palou, P. (2014). Psychology in the realm of sport injury: What it is all about. Revista de Psicologia del Deporte, 23, 395-400.

Andersen M.B. \& Ivarsson, A. (2016). A methodology of loving kindness: how interpersonal neurobiology, compassion and transference can inform researcher-participant encounters and storytelling. Qualitative Research in Sport, Exercise and Health, 8, 1-20.

Appaneal, R.N. \& Perna, F.M. (2014). Biopsychosocial Model of Injury. I: R. Eklund, G. Tenenbaum (Eds.), Encyclopedia of Sport and Exercise Psychology (pp. 74-77). Thousand Oaks, CA: SAGE.

Bahr, R. (2016). Why screening tests to predict injury do not work-and probably never will ...: a critical review. British Journal of Sports Medicine, 50, 776-780.

Baumeister, R.F. \& Leary, M.R. (1995). The need to belong: desire for interpersonal attachments as a fundamental human motivation. Psychological Bulletin, 117, 497-529.

Crane, J. \& Temple, V. (2015). A systematic review of dropout from organized sport among children and youth. European Physical Education Review, 21, 114-131.

Drawer, S. \& Fuller, C.W. (2001). Propensity for osteoarthritis and lower limb joint pain in retired professional soccer players. British Journal of Sports Medicine, 35(6), 402-408.

Eklund, R.C. \& Defreese, J.D. (2017). Burnout in sport and performance. Oxford Research Encyclopedia of Psychology. Advances online publication. doi: 10.1093/ acrefore/9780190236557.013.165

Frisch, A., Croisier, J.L., Urhausen, A., Seil, R., \& Theisen, D. (2009). Injuries, risk factors and prevention initiatives in youth sport. British Medical Bulletin, 92(1), 95-121.

Fuller, C.W., Ekstrand, J., Junge, A., Andersen, T.E., Bahr, R., Dvorak, J, Hägglund, M., McCrory, P., \& Meeuwisse, W.H. (2006). Consensus statement on injury definitions and data collection procedures in studies of football (soccer) injuries. British Journal of Sports Medicine, 40(3), 193-201. 
Gabbe, B.J., Finch, C.F., Bennell, K., \& Wajswelner, H. (2004). How valid is a self reported 12 month sports injury history? British Journal of Sports Medicine, 37, 545-547.

Goldberg, D.P., Gater, R., Sartorius, N., Ustun, T.B., Piccinelli, M., Gureje, O., \& Rutter, C. (1997). The validity of two versions of the GHQ in the WHO study of mental illness in general health care. Psychological Medicine, 27, 191-197.

Hagger, M.S., \& Chatzisarantis, N.L.D., Griffin, M., \& Thatcher, J. (2005). Injury representations, coping, emotions, and functional outcomes in athletes with sports-related injuries: a test of self-regulation theory. Journal of Applied Social Psychology, 35(11), 2345-2374.

Hughes, R.H. \& Coakley, J. (1991). Positive deviance among athletes: The implications of overconformity to the sport ethic. Sociology of Sport Journal, 8, 307-325.

Hägglund, M., Waldén, M., Til, L., \& Pruna, R. (2010). The importance of epidemiological research in sports medicine. Apunts Medicina de l'Espor, 45, 57-59.

Ivarsson, A., Johnson, U., \& Podlog, L. (2013). Psychological predictors of injury occurrence: A prospective investigation of professional Swedish soccer players. Journal of Sport Rehabilitation, 22, 19-26.

Ivarsson, A. \& Andersen, M.B. (2017). The researcher in loving care: Interrelatedness behind a mindfulness and sport injury prevention efficacy study. I: S.J. Zizzi \& M.B. Andersen (Eds.), Being mindful in sport and exercise psychology: Pathways for practitioners and students (pp. 215-230). Morgantown, WV: Fitness Information Technology.

Ivarsson, A., Johnson, U., Andersen, M.B., Tranaeus, U., Stenling, A., \& Lindwall, M. (2017). Psychosocial Factors and Sport Injuries: Meta-analyses for Prediction and Prevention. Sports Medicine, 47, 353-365. doi:10.1007/s40279-016-0578-x

Jewett, R., Sabiston, C.M., Brunet, J., O’Loughlin, E.K., Scarapicchia, T., O’Loughlin, J. (2014). School sport participation during adolescence and mental health in early adulthood. Journal of Adolescent Health, 55, 640-644.

Johnson, U. \& Ivarsson, A. (2011). Psychological predictors of sport injuries among junior soccer players. Scandinavian Journal of Medicine and Science in Sports, 21, 129-136.

Johnson, U., Tranaeus, U., \& Ivarsson, A. (2014). Current status and future challenges in psychological research of sport injury prediction and prevention: A methodological perspective. Revista de Psicología del Deporte, 23, 401-409.

Johnson, U. \& Ivarsson, A. (2018). Managing injuries among young athletes. In: C.J. Knight, C.G. Harwood \& D. Gould (Eds.) Sport Psychology for Young Athletes (pp. 174-184). Routledge Taylor \& Francis Group. 
Martindale, R.J., Collins, D., Wang, J.C., McNeill, M., Lee, K.S., Sproule, J., \& Westbury, T. (2010). Development of the Talent Development Environment Questionnaire for sport. Journal of Sports Sciences, 28, 1209-1221.

Meeuwisse, W.H., Tyreman, H., Hagel, B., \& Emery, C. (2007). A dynamic model of etiology in sport injury: The recursive nature of risk and causation. Clinical Journal of Sport Medicine, 17, 215-219.

Myndigheten för samhällsskydd och beredskap. (2010). Fysisk aktivitet och skador. https://www.msb.se/RibData/Filer/pdf/25550.pdf

Nixon, H.L., II. (1992). A social network analysis of influences on athletes to play with pain and injuries. Journal of Sport \& Social Issues, 16, 127-135.

Patel, D.R. \& Nelson, T.L. (2000). Sport injuries in adolescents. Medical Clinics of North America, 84, 983-1007.

Roderick, M., Waddington, I., \& Parker, G. (2000). Playing hurt - Managing injuries in English professional football. International Review for the Sociology of Sport, 35, 165-180.

Rogers, T.M. \& Landers, D.M. (2005). Mediating effects of peripheral vision in the life event stress/athletic injury relationship. Journal of Sport Exercise Psychology, $27,271-288$.

Siegel, D.J. (2010). The mindful therapist: a clinician's guide to mindsight and neural integration. New York, NY: Norton.

Soligard, T., Schwellnus, M., Alonso, J.M., Bahr, R., Clarsen, B., Dijkstra, P., ... Engebretsen, L. (2016). How much is too much? (Part 1) International Olympic Committee consensus statement on load in sport and risk of injury. British Journal of Sports Medicine, 50, 1030-1041.

Sparkes, A.C. (2015). Developing mixed methods research in sport and exercise psychology: Critical reflections on five points of controversy. Psychology of Sport and Exercise, 16, 49-59.

Steffen, K., Pensgaard, A.M., \& Bahr, R. (2009). Self-reported psychological characteristics as risk factors for injuries in female youth football. Scandinavian Journal of Medicine and Science in Sport, 19, 442-451.

Tranaeus, U., Johnson, U., Engström, B., Skillgate, E., \& Werner, S. (2014). Psychological antecedents of overuse injuries in Swedish elite floorball players. Athletic Insight, 6, 155-172.

Umberson, D. \& Montez, J.K. (2010). Social relationships and health: A flashpoint for health policy. Journal of Health and Social Behavior, 51, 54-66.

Waldén, M., Atroshi, I., Magnusson, H., Wagner, P., \& Hägglund, M. (2012). Prevention of acute knee injuries in adolescent female football players: cluster randomized controlled trial. BMJ, 344, e3042. 
Wiese-Bjornstal, D.M. (2003). From skinned knees and Pee Wees to menisci and masters: Developmental sport injury psychology. I: M.R. Weiss (Ed.), Developmental sport and exercise psychology: A lifespan perspective (pp. 525-568). Morgantown, WV: Fitness Information Technology.

Wiese-Bjornstal, D.M. (2010). Psychology and socioculture affect injury risk, response, and recovery in high-intensity athletes: A consensus statement. Scandinavian Journal of Medicine and Science in Sport, 20, 103-110.

Williams, J.M. \& Andersen, M.B. (1998). Psychosocial antecedents of sport injury: Review and critique of the stress and injury model. Journal of Applied Sport Psychology, 10, 5-25. 


\title{
KAPITTEL 2
}

\section{Med det danske U20 ishockeylandshold til VM}

\section{Stress og genopladning under træningslejre og konkurrencer}

\author{
Kristoffer Henriksen ${ }^{\star}$, Astrid Becker-Larsen \& Carsten Hvid Larsen \\ Institut for Idræt og Biomekanik, Syddansk Universitet, Odense, Denmark
}

Resumé: I dette studie undersøgte vi de danske U-20 ishockeyspilleres stress og genopladning under en længerevarende træningslejr og det efterfølgende verdensmesterskab. Formålet var at følge udviklingen i spillernes stress-og genopladningsbalance samt at kortlægge deres oplevede kilder til stress og genopladning. Vi foretog dataindsamling via et spørgeskema, kvalitative interviews og en trænerdagbog. Resultaterne viste, at spillerne var i positiv stressgenopladningsbalance, hvilket i deres oplevelse havde en positiv indvirkning på deres trivsel og præstationer. Vi kunne inddele spillernes oplevede kilder til stress og genopladning i organisatoriske, sociale, personlige og sportslige, hvor beslutninger og strategier på organisatorisk niveau viste sig at spille en afgørende rolle i at reducere unødig stress og skabe gode rammer for genopladning. Med baggrund i resultaterne anbefaler vi, at trænere og sportschefer nøje overvejer, hvordan deres beslutninger og planlægning af træningslejre og konkurrencer potentielt har stor indflydelse på deres atleters stress og genopladning.

Nøgleord: RESTQ-sport, anvendt sportspsykologi, organisationspsykologi i sport

\begin{abstract}
The present case study investigates stress and recovery of the Danish national under20 ice hockey players during a training camp and the following World Championship. The aims were to track their stress-recovery states longitudinally, and to map their main sources of stress and recovery. Methods included a survey, qualitative interviews and a coach diary. Results showed well-balanced stress-recovery states during the entire period, and the athletes stated that this positively affected their well-being, and performance. The athletes' perceived sources of stress and recovery were classified into organizational, social, personal and athletic, with the organizational decisions and strategies playing a major role in reducing unnecessary stress and providing a good setting for engaging in recovery. The results lead us to suggest that coaches and managers be very mindful of the potential influence of their decisions on the athletes' stress and recovery when preparing training camps and participation in major competitions.
\end{abstract}

Keywords: RESTQ-sport, applied sport psychology, organizational psychology in sport

\footnotetext{
${ }^{\star}$ Korresponderende forfatter: Kristoffer Henriksen, Institut for Idræt og Biomekanik, Sundhedsvidenskabelig fakultet, Syddansk Universitet, Danmark. Epost: khenriksen@health.sdu.dk

Sitering av denne artikkelen: Henriksen, K., Becker-Larsen, A., \& Larsen, C.H. (2018). Med det danske U2O ishockeylandshold til VM: Stress og genopladning under træningslejre og konkurrencer. I T. Haugen \& R. Høigaard (Red). Trender i idrettspsykologisk forskning i Skandinavia (Kap. 2, s. 29-46). Oslo: Cappelen Damm Akademisk. DOI: https://doi.org/10.23865/noasp.39.ch2

Lisens CC-BY 4.0
} 


\section{Introduktion}

I jagten på toppræstationer presser eliteatleter deres fysik og psyke til det yderste. Samtidig har de ofte en stresset hverdag med krav om både træning og uddannelse. Genopladning en vigtig faktor for, at atleterne kan bibeholde engagement og fokus i træningen. Da Team Danmark i 2014 udviklede et "restitutionskoncept" (Hansen, Henriksen, Johansen, \& Jørgensen, 2014), fremgik det, at der manglede forskningsbaseret viden om stress og genopladning $\mathrm{i}$ et psykologisk perspektiv i elitesport. Samtidig havde flere danske forbund bemærket, hvordan deres atleters engagement, motivation og præstation kunne falde mod slutningen af en længerevarende træningslejr eller konkurrence. Derfor iværksatte man et forskningsprojekt med tre formål: at monitorere stress- og genopladningsniveauerne hos danske eliteatleter under længerevarende træningslejre og konkurrencer, at forstå hvilke kilder til stress atleterne oplever og at afdække deres genopladningsstrategier. I projektet indgik fire danske landshold: kvindelandsholdet i fodbold, orienteringslandsholdet, sejllandsholdet og U2o herre ishockeylandsholdet. Denne artikel præsenterer data fra undersøgelsen af det danske U2o ishockeylandshold.

I nærværende sammenhæng forstås begrebet stress i tråd med sportspsykologisk forskning som en reaktion på belastning (ikke som en sygdom) (Kellmann, 2002). Når atleter oplever ubalance mellem krav og ressourcer, opstår en stresstilstand. Positiv her-og-nu-stress er oplevelsen af øget spænding med følgende øget energi. Negativ her-ognu-stress kommer til udtryk som en tvivlende tro på at kunne lykkes, flakkende koncentration og nedbrydende indre tale. Varig stress opstår, når atleter over længere tid ikke oplever sig i stand til at håndtere de krav, de møder. Selvom sportspsykologien primært har behandlet stress som et individuelt anliggende, har sportspsykologisk forskning identificeret, at atleter oplever belastninger (stressorer) fra flere forskellige sider (Sarkar \& Fletcher, 2014). Disse inkluderer belastninger knyttet til selve konkurrencen ( $\mathrm{fx}$ forberedelse, skader, forventninger og modstandere), organisationen (fx selektion, træningsmiljø, rollekonflikter) og personlige forhold udenfor sporten (fx skole/uddannelse, familie og $ø$ konomi). Nyere forskning har påvist, at en stor del af den stress, som 
eliteatleter oplever, stammer fra organisatoriske forhold såsom manglende kommunikation fra ledelsen, uretfærdige selektionsprocedurer, utilstrækkelig økonomisk støtte, manglende forståelse fra træneren eller dårlige logistiske forhold (Fletcher \& Wagstaff, 2009; Sarkar \& Fletcher, 2014).

Genopladning defineres som "an inter-individual and intra-individual multi-level (e.g., psychological, physiological, social) process in time for the re-establishment of performance abilities" (Kellmann \& Kallus, 2001, s. 22). Genopladning er ikke bare passiv (fysisk afslapning, massage), men involverer aktiviteter, der har til formål at genetablere atletens evne til at præstere. Selvom genopladning involverer både en fysisk, psykologisk og social komponent, har forskningen hidtil langt overvejende haft fokus på fysiologisk restitution (herunder udstrækning, ernæring, massage, hydroterapi og kompressionsbeklædning) (Bishop, Jones, \& Woods, 2008). Forskning i psykologiske aspekter af genopladning har primært fremhævet individuelle strategier som selvregulering, positiv indre dialog og mindfulness (Beckmann \& Kellmann, 2004; Gustafsson, Skoog, Davis, Kenttä, \& Haberl, 2015; Sarkar \& Fletcher, 2014).

Stress og genopladning er uafhængige men forbundne størrelser (Kellmann, 2010). Jo større grad af belastning, desto større behov for genopladning. Atleter kan håndtere en relativ stor fysisk og mental belastning, hvis de formår at genoplade nok og med kvalitet (Kellmann, 2010). En god stress-genopladningsbalance skaber øget træningskvalitet og præstationsevne. Omvendt inkluderer konsekvenserne af manglende genopladning (underrecovery) (Kellmann, 2002) koncentrationsbesvær, småskader, søvnbesvær, træthed, nedsat præstation, dårligt humør, manglende motivation og på længere sigt overtræning, udbrændthed og dropout (Gustafsson, Hassmén, Kenttä, \& Johansson, 2008; Jurimae, Maestu, Purge, \& Jurimae, 2004).

Undersøgelser i atletik, roning og cykling har ligeledes påvist, at atleter med en hensigtsmæssig stress-genopladningsbalance har bedre forudsætninger for at toppræstere (Brink, Visscher, Coutts, \& Lemmink, 2012; Kalda, Jurimae, \& Jurimae, 2004).

Træningslejre og konkurrencer udgør en særlig udfordring i atleternes liv (Elbe \& Kellmann, 2007). De er ofte kendetegnet ved intenst og 
ensidigt fokus på træning og præstation, høje forventninger, store træningsmængder, ændrede bo-, sove-, spiseforhold og ændrede relationer. Tidligere forskning har fundet, at stress og genopladning fluktuerer over en konkurrenceperiode (fx Filho et al., 2013) med højere niveauer af træthed og mindsket energi i slutningen af konkurrenceperioden (King, Clark, \& Kellmann, 2010).

Forskningsspørgsmålene, vi vil besvare, er: (1) hvordan udviklede de danske U2O ishockeyspilleres stress- og genopladningsbalance sig over en træningslejr og under det efterfølgende VM, (2) hvilke kilder til stress oplevede atleterne i løbet af perioden, og (3) hvilke strategier til genopladning benyttede de.

\section{Metode}

Kontekstualisering er en stærk trend i sportspsykologisk forskning (Schinke \& Stambulova, 2017). I tråd med denne trend er denne undersøgelse designet som et case-studie, der er defineret som en "strategi til empirisk udforskning af et udvalgt nutidigt fænomen, i dets naturlige sammenhæng ved anvendelse af forskellige datakilder" (Ramian, 2012, s. 16). Datakilderne var en survey (RESTQ-sport), semistrukturerede interviews med atleter og en trænerdagbog.

Casen er det danske U2o herre ishockeylandshold. Til trods for at Danmark er en lille ishockeynation, har vi igennem flere år deltaget ved det årlige U2o-VM i ishockey. Turneringen er højt prioriteret og kun de 10 bedste lande kan deltage. Her tester nuværende og kommende NHLspillere hinanden. I slutningen af december 2015 drog det danske U2O herre ishockeylandshold på træningslejr i Sverige for at forberede sig på årets VM. Bruttotruppen bestod af 28 spillere (16-19 år) og blev løbende skåret ned til den endelige trup på 23 spillere. Efter træningslejren tog holdet direkte til VM i Finland. Trods en vanskelig pulje kvalificerede holdet sig til kvartfinalen, hvor de tabte til storfavoritten Rusland. Både trænere og spillere indvilgede $i$ at indgå i projektet. Vi blev enige om, at selve casen ville blive navngivet, men at individuelle spillere ville blive anonymiseret. Vi oplyste spillerne om, at de kunne trække sig fra projektet uden sanktioner. 


\section{Dataindsamling}

Vi anvendte spørgeskemaet Recovery-Stress Questionnaire for Athletes (RESTQ-sport) i en dansk udgave (Elbe, 2008) til kvantitativt at belyse atleternes stress-genopladningsbalance. RESTQ består af 76 spørgsmål, hvor atleten skal indikere, i hvor høj grad han/hun har oplevet stress-symptomer eller engageret sig i genopladningsaktiviteter i løbet af de sidste tre dage. Hvert spørgsmål besvares på en likert-skala fra o (aldrig) til 6 (altid). De 76 spørgsmål relaterer til fire hovedkategorier (generel og sportsspecifik stress, samt generel og sportsspecifik genopladning) og 19 subkategorier. Ishockeyspillere udfyldte RESTQ to dage inden afrejse, to gange under træningslejren og tre gange under VM (i alt seks gange) svarende til hver fjerde dag.

Vi foretog kvalitative interviews med tre spillere under træningslejren og igen umiddelbart efter VM, med det formål at nuancere de kvantitative resultater og at afdække kilder til stress og strategier til genopladning. $\mathrm{Vi}$ anvendte en semistruktureret interviewguide med fire overordnede temaer. Først bad vi atleten beskrive en normal dag under rejseperioden og sammenligne denne med en dag derhjemme ( $\mathrm{fx}$ træningsmængde, mad, søvn og sociale aktiviteter). Med brug af en batterimetafor spurgte vi dernæst atleterne "hvad dræner dine batterier?" og "hvad genoplader dine batterier?" I fjerde del bad vi spillerne beskrive, hvordan de oplevede balancen mellem stress og genopladning, og hvordan den påvirkede deres velbefindende og præstation. For at forstyrre mindst muligt blev interviews under træningslejren udført af den medrejsende sportspsykolog (denne artikels tredjeforfatter), mens interviews efter VM blev foretaget af en af projektets forskningsmedarbejdere (artiklens andenforfatter). Sportspsykologens samtaler med spillerne blev ikke transskriberet, kodet og brugt som data, men blev i anonymiseret form bragt ind i teamets diskussioner af resultater med henblik på at understøtte og udfordre konklusioner.

Træneren udfyldte dagligt en dagbog, der bestod af to dele. Først vurderede træneren dagens trænings-/konkurrencebelastning på en skala fra 1 (en dag med lav belastning) til 5 (en dag med høj belastning). Dernæst noterede træneren øvrige faktorer, han mente kunne influere på atleternes stress-genopladningsniveau (lang transport, rejsedag, ændringer i planen m.m.). 
Hver datakilde har specifikke fordele og tilsammen danner de basis for en dyb og hel analyse af casen. Figur 1 viser et overblik over dataindsamlingen.

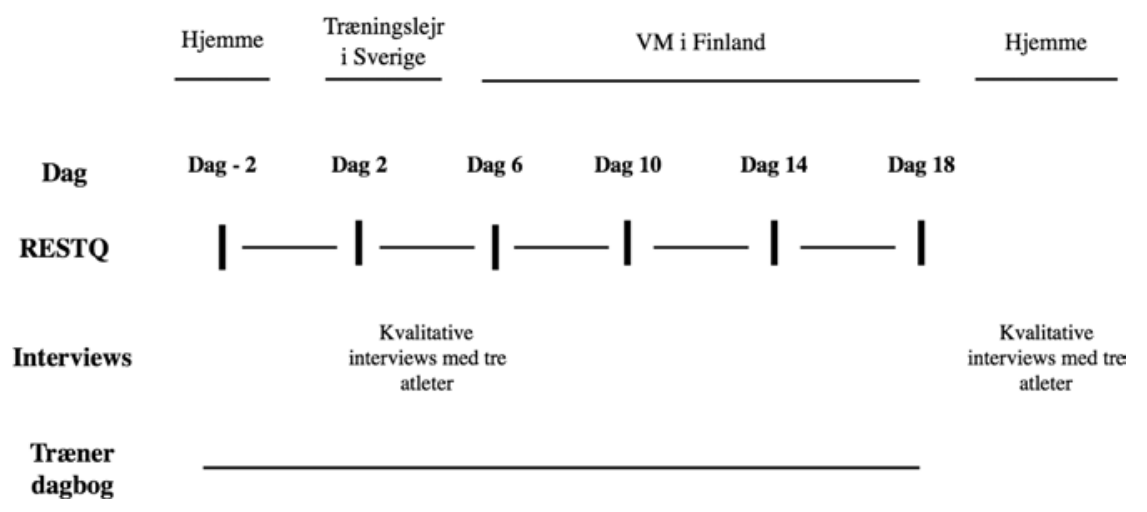

Figur 1. Overblik over dataindsamlingsperioden og de tre datakilder.

\section{Dataanalyse}

Baseret på de statistiske data lavede vi individuelle profiler for hver enkelt spillers udvikling på alle 19 subskalaer over tid. Dernæst beregnede vi gennemsnit for de to total-skalaer (total stress og total genopladning) og for de fire overordnede skalaer (generel og sportsspecifik stress samt generel og sportsspecifik genopladning) og for hele holdet. Vi sammenlignede gennemsnitsværdierne for de overordnede skalaer under træningslejre og konkurrence ved hjælp af en parret T-test (konfidensinterval 95\%) for at undersøge, om der var signifikant forskel mellem træningslejr og konkurrence.

For at styrke validiteten (da der var to interviewere) blev interviewguiden udviklet i fællesskab, og interviewer to transskriberede de første interviews. De transskriberede interviews blev analyseret via Braun, Clarke \& Weates seks skridt (Braun, Clarke, \& Weate, 2017): (1) Vi læste materialet grundigt i sammenhæng; (2) Vi kodede materialet deduktivt i overordnede temaer (kilder til stress, strategier til genopladning osv.) og induktivt (det nærmere indhold i hvert tema); (3) Vi arrangerede de induktivt udviklede koder i højere ordens koder (fx "organisatoriske", "sociale", "personlige" og "sportslige" kilder til stress); (4) Vi diskuterede, 
reviderede og afgrænsede temaerne; (5) Vi kondenserede beskrivelserne af hver undertema; (6) Vi skrev resultaterne sammen til et samlet afsnit. Vi brugte trænerens dagbog til at perspektivere analyserne af de kvantitative og kvalitative data.

\section{Resultater - et Landshold i Balance Stress-genopladningsbalancen og dens udvikling}

Figur 2 viser udviklingen i gennemsnittet af spillernes samlede stress og genopladning baseret på besvarelserne fra RESTQ. Resultaterne viser lave niveauer af stress og høje niveauer af genopladning blandt alle spillere. En nærmere analyse viser, at de enkelte underskalaer indenfor stress og genopladning ikke afviger fra det generelle billede. De individuelle profiler viser desuden, at gennemsnittet ikke skjuler store individuelle forskelle. Samtlige spilleres profiler viser en hensigtsmæssig balance mellem stress og genopladning.

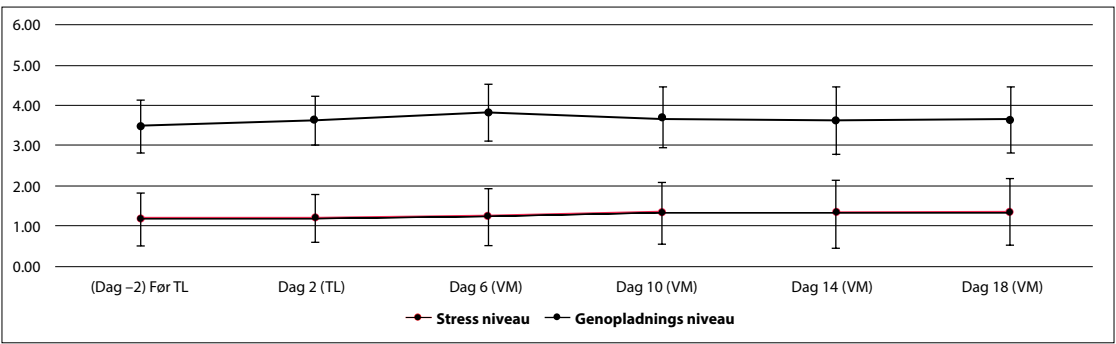

Figur 2. Total stress og total genopladning med standardafvigelse under træningslejren (TL) og VM.

Figuren viser også, at der ikke er nogen signifikant udvikling over tid. Dette mønster går igen i hver enkelt individuelle profil, således at manglende udvikling i gennemsnittet for gruppen ikke dækker over store individuelle forskelle. På baggrund af den parrede t-test finder vi ingen statistisk signifikant forskel mellem den totale stress og genopladning under træningslejren og under VM. På baggrund af de statistiske data kan vi konkludere, at hver enkelt spillers totale stressniveau var lavt og det totale genopladningsniveau højere i hele perioden. 
Data fra interviews og trænerdagbog både bekræfter og nuancerer de kvantitative data. Helt generelt beskriver spillerne et velafbalanceret niveau af stress og genopladning både under træningslejren og VM. Eksempelvis opsummerer Sebastian sin oplevelse efter VM: "Jeg synes egentlig, at jeg havde god energi både under troningslejren og VM, selvom der var dage, hvor jeg var trcet. Sarligt på kampdagene under VM havde jeg en god energi." De spillere, der kom fra vigtige klubkampe, oplevede rejsedagen og de første dage med landsholdet som særligt hårde.

Til trods for at de kvantitative data ikke viser forskel mellem træningslejr og VM, beskriver spillerne i interviewene, at stemningen under de to begivenheder var forskellig. Det hang især sammen med det øgede fokus på resultater under konkurrencen. Sebastian beskrev stemningen under VM som "mere intens" og holdkammeraterne som "mere koncentrerede og seriøse" end under træningslejren. Netop derfor var spillerne bevidste om at prioritere genopladning. Som Troels eksempelvis sagde: "Der bliver krovet meget af os, både under troningslejren og VM. Stor troningsmoengde og mange kampe. Det er hårdt. Så jeg sørger for at slappe meget af, både mentalt og fysisk." Samtidig beskrev de to spillere, at de trivedes, var glade og oplevede et stærkt fællesskab både under træningslejren og VM.

\section{Kilder til Stress og Genopladning}

Tabel 1 viser de kilder til stress og genopladning, der fremgår af spillerinterviews og trænerdagbog. Som et resultat af analysen er kilderne til stress og genopladning opdelt i fire hovedkategorier: organisatoriske, sociale, personlige og sportslige.

\section{Organisatoriske kilder til stress og genopladning}

Organisatoriske kilder til stress beskriver de organisatoriske rammer eller set-up, som spillerne oplever som stressende, og som dræner deres batterier. Under træningslejren bestod programmet af faste møde-, trænings-, testkampe- og spisetidspunkter samt en længere pause efter frokost på ca. tre timer. Af interviews og trænerdagbog fremgik det, at denne pause nogle dage blev inddraget til møder, hvilket betød, at spillerne havde for korte pauser. Sebastian beskrev, hvordan møder i middagspausen gjorde det svært at nå at slappe ordentlig af: "Man ved hele tiden, at man snart 
Tabel 1. Kilder til stress og genopladning fremhævet af de danske ishockeyspillere.

\begin{tabular}{|c|c|c|c|c|}
\hline & Organisatoriske & Sociale & Personlige & Sportslige \\
\hline $\begin{array}{l}\text { Kilder til } \\
\text { stress }\end{array}$ & $\begin{array}{l}\text { For korte pauser } \\
\text { Stor træningsmængde } \\
\text { og hårde testkampe } \\
\text { AEndringer i } \\
\text { dagsprogrammet }\end{array}$ & $\begin{array}{l}\text { Afsavn ift. } \\
\text { familie og venner } \\
\text { For meget socialt } \\
\text { samvær }\end{array}$ & $\begin{array}{l}\text { Tankemylder } \\
\text { efter en } \\
\text { præstation }\end{array}$ & $\begin{array}{l}\text { Fejl og dårlige } \\
\text { præstationer } \\
\text { i træning og } \\
\text { konkurrence } \\
\text { Usikkerhed om } \\
\text { udvælgelse } \\
\text { Spilleragenter }\end{array}$ \\
\hline $\begin{array}{l}\text { Kilder til } \\
\text { genopladning }\end{array}$ & $\begin{array}{l}\text { Struktureret og } \\
\text { rutinepræget program } \\
\text { Skemalagt tid til } \\
\text { genopladning } \\
\text { Fælles måltider } \\
\text { Feedback fra trænere } \\
\text { og samtaler med } \\
\text { sportspsykolog }\end{array}$ & $\begin{array}{l}\text { Sociale } \\
\text { aktiviteter med } \\
\text { holdkammerater } \\
\text { Dialog med } \\
\text { familie og venner } \\
\text { i Danmark } \\
\text { Besøg af } \\
\text { familien }\end{array}$ & $\begin{array}{l}\text { Alenetid } \\
\text { Have ryddet } \\
\text { bordet } \\
\text { hjemmefra } \\
\text { Positiv medie- } \\
\text { opmærksomhed }\end{array}$ & $\begin{array}{l}\text { Succes i } \\
\text { sporten }\end{array}$ \\
\hline
\end{tabular}

skal til møde, så man kan ikke logge sig til at sove - og bagefter er der også for kort tid til at slappe af, før vi skal videre til det noeste." Dage med mange aktiviteter og korte pauser tog mere energi end dage med få aktiviteter og længere pauser.

Spillerne nævnte, at træningslejrens store træningsmongde og hårde testkampe var en kilde til stress. Eksempelvis sagde Troels: "I går var hård. Først morgentroning, derefter kamp mod Sverige. Og så skulle jeg til fysioterapeut for at blive klar til dagen efter. Det tager bare meget energi." Trænerdagbogen bekræfter billedet. Eksempelvis er tre dage i træk markeret med 3-taller (stor belastning), og træneren har noteret: "Spillerne virker mentalt trotte."

Som en sidste organisatorisk kilde til stress nævner spillerne andringer i dagsprogrammet, der ellers var velstruktureret. Troels beskriver:

"Det er stressende, når der dukker uventede ting op. Forleden blev der lagt et ekstra fysisk troningspas, hvor jeg havde planlagt at slappe af. Jeg vil jo gerne vore en del af holdet, men jeg havde også brug for at slappe af. Det kan godt ødelogge mit energiniveau."

Organisatoriske kilder til genopladning er de overordnede rammer samt de initiativer og beslutninger fra ledelsen (trænere og forbund), 
som hjalp spillerne med at genoplade. Spillerne indikerede, at det strukturerede og rutinepreegede program skabte forudsigelighed og ro. Til de daglige informationsmøder blev spillerne informeret om dagens og den kommende dags program, således at de hele tiden var orienteret om, hvad der skulle ske. Jonathan sagde: "Det giver mig ro i maven, at der er et skema. Hvornår skal vi op om morgenen? Hvornår har vi pauser? Hvornår skal vi spise? osv. Så skal jeg ikke hele tiden troefe beslutninger." Samtidig indeholdt programmet skemalagt tid til genopladning, der bestod af kortere eller længere pauser i løbet af dagen, som spillerne selv rådede over. Sebastian beskrev, hvordan de skemalagte pauser gav ham mulighed for at slappe af eller være sammen med de andre spillere. Han pointerede: "Pauserne var godt planlagt. De kom som regel, når vi havde brug for dem."

Spillerne boede sammen, og Troels beskrev, hvordan et godt set-up omkring indkvartering skabte gode rammer for genopladning. Som et eksempel beskrev han, hvordan frelles måltider havde stor betydning for hans genopladning:

"Det er virkelig fedt, at der er buffet tre gange om dagen. Jeg kan spise, lige hvad jeg vil, og så meget, jeg vil. Men isæer er det hyggeligt, at vi spiser samlet som hold. Vi snakker og griner, og foellesskabet udenfor banen giver energi."

Både under træningslejren og VM gav alle spillerne udtryk for, at feedback fra træneren og samtaler med sportspsykologen var afgørende ift. at håndtere tanker og forventninger. Træneren gav ros, konstruktiv kritik eller satte specifikke krav. Jonathan beskriver, hvad det betød for ham:

"Jeg får meget energi af at få både ros og kritik fra træneren. Når jeg ved, hvad træneren gerne vil have, og hvad jeg skal gøre bedre, så bruger jeg ikke energi på at tonke over, om jeg nu gjorde det rigtigt, og hvad han nu tonker om mig. Det betyder virkelig meget for mit overskud og fokus."

Sportspsykologen tilbød individuelle samtaler om mentale strategier før, under og efter kamp. Disse samtaler fulgte op på længerevarende individuelle forløb afholdt i Danmark. Efterfølgende evaluerede spilleren og sportspsykologen, hvordan det var gået med strategien under kampen. De interviewede spillere beskrev dette som en genopladningsstrategi, fordi samtalerne hjalp med at sætte udfordringer i perspektiv 
og acceptere nervøsitet. Det reducerede unødig stress og gjorde det lettere at få ny energi. Generelt gav spillerne udtryk for, at de oplevede en positiv dialog med staben (trænere, sportspsykolog, fysioterapeut) under træningslejren og VM, og at denne gode dialog var vigtig for at bevare fokus.

\section{Sociale kilder til stress og genopladning}

Sociale kilder til stress refererer til spillernes sociale relationer til andre på og udenfor holdet, som dræner deres energi. Træningslejren og VM blev afviklet midt i julehøjtiden, hvilket betød, at enkelte spillere oplevede afsavn ift. familie og venner derhjemme. Som Troels beskrev: "Lige midt $i$ juleferien, så savner man dem derhjemme. Det tager ind imellem energi og fokus. Når jeg tonker på det, så gloeder jeg mig til at komme hjem." At afsavnet ift. venner og familie oplevedes som en kilde til stress, skyldtes ifølge spillerne, at de var væk i en længere periode og i julen, hvor familien derhjemme var samlet.

Under hele perioden boede spillerne på værelse to og to og var sammen omkring træning, kampe, måltider, møder m.m. I samtaler med sportspsykologen gav nogle spillere udtryk for, at de oplevede, at for meget socialt samvar var en kilde til stress. Det kom for eksempel til udtryk, når de kom med negative bemærkninger i træningen rettet mod specifikke medspillere.

Men det sociale blev også beskrevet som en meget vigtig kilde til genopladning. Sociale kilder til genopladning beskriver spillerne som sociale relationer til andre på og udenfor holdet, som spillerne oplevede gav dem energi. De interviewede spillere beskrev, at sociale aktiviteter med holdkammerater var en essentiel kilde til genopladning. Under træningslejren og VM engagerede spillerne sig i forskellige aktiviteter, herunder samtaler på værelset, så film på computeren eller spillede PlayStation og Xbox i "Players Lounge”. Under lejren fremhævede Jonathan, hvordan den sociale interaktion påvirkede hans trivsel og præstation positivt: "Det giver meget energi at vore sammen med de andre. Vi fungerer godt sammen på holdet. Alle kan snakke med alle, og folk er glade. Det giver godt humør, hvilket helt sikkert har en effekt på troning og kamp." 
Foruden relationerne internt på holdet beskrev spillerne også, hvordan dialog med familie og venner i Danmark kunne bidrage til genopladning. Denne dialog handlede både om sporten og om forhold udenfor sporten, hvilket Troels beskrev vigtigheden af: "Det giver positiv energi at få en besked hjemmefra, at vide det går godt, og at kunne følge lidt med i deres hverdag." Dialogen med venner og familie gav en pause fra ishockey og mindede om, at der er andet og mere i livet end sport. Flere spillere fik under VM besøg affamilien, som de ofte mødtes med ude i byen, hvilket gav et brud på rutinerne og blev fremhævet som en kilde til genopladning. Kontakten med centrale nøglepersoner åbnede mulighed for at søge støtte, når der var udfordringer.

\section{Personlige kilder til stress og genopladning}

Personlige kilder til stress beskrives som personlige situationer og forhold i og udenfor sporten, som dræner spillernes ressourcer. Under træningslejren og særligt under VM beskrev spillere, at de oplevede tankemylder efter en prostation. Tankemylderet var særlig problematisk under VM, da flere af kampene blev afviklet sent om aftenen, og spillerne havde svært ved at falde til ro og sove. Sebastian fortæller: "De aftener pumpede adrenalinen rundt $i$ kroppen og tankerne $i$ hovedet. Jeg lå og tonkte på, om jeg havde spillet godt eller dårligt. Jeg var trat, men havde svoert ved at falde i søvn." Når kampene lå sent, fik spillerne hverken evalueret med holdet eller træneren. De oplevede, at de ikke fik "lukket kampen ned", og at den derfor blev ved med at forstyrre.

Personlige kilder til genopladning er personlige strategier eller aktiviteter i og udenfor sporten, som spillerne engagerede sig i for at få energi. Alenetid var beskrevet som en kilde til genopladning blandt alle spillerne. Jonathan beskrev det således: "Nogle gange gik jeg lidt rundt udenfor alene. Andre gange tog jeg mine hovedtelefoner på. Jeg hørte ikke altid musik, men når jeg havde dem på, forstyrrede de andre mig ikke." Alenetiden blev brugt på forskellige aktiviteter såsom at høre musik, se film/serier, surfe på internettet, slappe af eller sove.

Flere spillere havde ryddet bordet hjemmefra ved at have afklaret skole og arbejdsopgaver, inden de tog af sted. Det betød, at de kunne koncentrere sig fuldstændig om træningslejren og VM, og at opgaver udefra ikke 
stjal deres opmærksomhed. Sebastian understregede, at "Det har voret en lettelse kun at skulle fokusere på hockey."

Endelig beskrev de interviewede spillere, at medieopmorksomhed gav dem energi. Som Jonathan fortæller: "Det er sjovt at loese, når medier udtaler sig om en. Det giver energi og motivation til at kompe videre." Mesterskabet var en succes, og det betød, at medieopmærksomheden oftest var positiv. Spillerne oplevede ikke at skulle håndtere kritik og dårlige evalueringer. De oplevede positiv omtale på de sociale medier som en stor anerkendelse.

\section{Sportslige kilder til stress og genopladning}

Som en sidste kategori beskriver flere spillere i interviews og samtaler med sportspsykologen kilder til stress, der er specifikt relateret til trænings- eller konkurrencesituationer. Spillere fremhævede, at fejl og dårlige prostationer i troning og konkurrence stjal energi. Oplevelsen af ikke at lykkes påvirkede både den enkeltes humør og holdets energi, og som Jonathan beskrev det: "Vi ved, at vi ikke er det bedste hold, men det er stadig hårdt at spille to kampe uden at score. Det påvirker alles humør, når vi taber." Han beskriver videre, hvordan det at lave fejl fjernede hans fokus fra opgaven.

"Jeg lavede en del fejl under kampen, og så blev jeg irriteret på mig selv. Jeg slog $i$ boenken. Jeg ved, at jeg egentlig ikke burde toenke på mine fejl, men jeg kan ikke lade vore. Iscer under og lige efter kampene bliver jeg ved med at toenke på, hvorfor jeg gjorde sådan og sådan."

Under træningslejren kæmpede spillerne om at få en plads på holdet til VM, hvilket betød, at de i træningssituationerne og testkampene brugte meget energi på at overveje, om de ville blive udvalgt eller ej. Jonathan beskrev, hvad usikkerheden om udvolgelse betød for ham: "Jeg skulle hele tiden prostere. Jeg frygtede jo, hvad der ville ske, hvis jeg spillede dårligt. Den der uvished. Det brugte jeg meget energi på at tonke over." Sebastian supplerede: "Jeg er allerede udtaget, men jeg kan se, at de spillere, som komper om en plads, er mere stressede og bliver hurtigere irriterede." Spillerne beskrev dog samtidig, at kampen om pladserne betød, at de ydede deres maksimale. 
Også spilleragenter og tanker om at blive spottet under VM tog fokus og energi. Sebastian beskrev, hvordan det kunne stjæle hans opmærksomhed under kampene:

"VM er det bedste udstillingsvindue $i$ hele verden. Der var altid folk fra andre klubber ude og kigge. Måske var det derfor, man blev irriteret, når man lavede en fejl. Man tonker for meget på det og glemmer at leve i nuet og 'spille kampen'."

Sportslige kilder til genopladning refererer til oplevelser i træning eller konkurrence, der gav energi. Spillerne fremhævede især succes $i$ sporten, her med Sebastians ord: "At vinde en kamp, det er jo selvfølgeligt kampe stort. Det giver så meget energi at have succes med holdet. Men også når jeg personligt lykkes med at spille godt."

\section{Diskussion}

Kontekstualisering er en væsentlig trend i moderne sportspsykologi. Det gælder i den anvendte sportspsykologis fokus på kulturelt tilpassede interventioner og på konsulentens kulturelle kompetence. Det gælder også i anvendelsesorienteret forskning, der oftere og oftere udføres med ambitionen om at udvikle situeret og kulturelt forankret viden (Ryba, Stambulova, Si, \& Schinke, 2013; Schinke \& Stambulova, 2017). Dette casestudie undersøgte det danske ishockeylandsholds stress og genoppladning under årets vigtigste konkurrence, nemlig VM. Resultaterne kan have relevans bredt i sport, men de har fundet direkte anvendelse blandt trænere og ledere i ishockeyforbundet, der benytter resultaterne $\mathrm{i}$ planlægning af deres aktiviteter. På den måde har lokalt forankret viden haft direkte indvirkning på praksis.

Undersøgelsen er ikke uden metodiske udfordringer. For det første er validiteten af RESTQ-sport kritiseret (Davis, Orzeck, \& Keelan, 2007). For det andet er alle former for selvrapport problematisk, særligt midt under et mesterskab, hvor spillerne kan nedtone udfordringer for ikke at virke svage, hvis de er bange for, at trænerne får indblik i deres svar. Sidst kan trænernes involvering i projektet allerede inden træningslejren have skabt øget fokus på genopladning, hvilket kan være kan en af grundene til, at vi finder spillerne i god balance. Især de to sidste problemer er svære 
at undgå, når man gerne vil udvikle kontekstspecifik og relevant viden under et reelt mesterskab. Vi mener, at data-triangulering (spørgeskema, interview og dagbog), forskertriangulering (fælles datakodning) og en tydelig oplysning om, at data vil blive anonymiseret, har reduceret disse udfordringer.

Holdets sportspsykolog har været involveret i projektet ved at foretage interviews under træningslejren. Man kan argumentere for, at dette skaber udfordringer, både for sportspsykologen (hvis jeg finder, at en spiller er stresset, er jeg så forsker eller sportspsykolog?) og for spillerne (er han forsker eller min hjælper?). Det var aftalt på forhånd, at hvis en spiller viste højt stressniveau, ville sportspsykologen hjælpe vedkommende, og denne spiller ville udgå af forskningsprojektet. Det blev ikke nødvendigt. Samtidig var sportspsykologens deltagelse en fordel. Spillerne var vant til, at han behandlede deres bekymringer fortroligt (tavshedspligt), og sportspsykologen fik en ekstra indsigt i holdets stresstilstand.

I undersøgelsen fandt vi en god balance mellem stress og genopladning hos de danske U2o ishockeylandsholdsspillere under en længerevarende træningslejr og et efterfølgende VM. Det overraskede os. På baggrund af tidligere forskning (Elbe \& Kellmann, 2007; Filho et al., 2013; King et al., 2010) forventede vi at se øgede stressniveauer og faldende genopladning i løbet af perioden, fordi træningslejre og konkurrencer er kendetegnet ved stor træningsbelastning, høje forventninger, uvante omgivelser osv. Der kan være mange forklaringer på, at det var muligt for de danske spillere at opretholde en positiv balance mellem stress og genopladning. Hele perioden var velplanlagt, og det strukturerede og rutineprægede program med skemalagt tid til genopladning gjorde det muligt for spillerne at balancere mellem alenetid og sociale aktiviteter. Samtidig havde forbundet prioriteret at have en medrejsende sportspsykolog, der hjalp spillerne med at håndtere forventninger, acceptere nervøsitet og sætte præstationer i perspektiv.

Flere kilder til stress var samtidig kilder til genopladning. Socialt samvær var en væsentlig kilde til genopladning, mens for meget socialt samvær kunne opleves som stressende. Alenetid blev brugt som strategi til genopladning, men for meget tid alene, særligt efter en kamp, skabte tankemylder og søvnbesvær. Det viser, at optimale rammer for genopladning 
er individuelle og ikke et spørgsmål om enten eller, men om hvor meget og hvornår.

En anden væsentlig trend i moderne sportspsykologisk forskning er fokus på organisationen eller miljøet, som atleterne befinder sig i. Eksempler er forskning i talentmiljøer (Henriksen, Stambulova, \& Roessler, 2010) og organisationskultur og ledelse (Fletcher \& Wagstaff, 2009). Som et resultat af analysen kunne vi inddele atleternes oplevede kilder til stress og genopladning i fire overordnede kategorier: organisatoriske, sociale, personlige og sportslige. Faktisk var organisatoriske kilder til stress og genopladning dominerende i atleternes beskrivelser. Et nøglefund var således, at beslutninger på organisatorisk niveau (indkvarteringsform, madordning, lokaler, program, medrejsende eksperter m.m.) kan medvirke til at reducere unødig stress og skabe rammer for optimal genopladning. Hvis trænere ser genopladning som en individuel opgave, misser de deres egen rolle i at skabe sådanne rammer. Disse resultater bekræfter forskning i organisatorisk stress, nemlig at en stor del af den stress, som atleter oplever under mesterskaber, ikke alene stammer fra sportens krav, men fra "alt det udenom" (Fletcher \& Wagstaff, 2009; Sarkar \& Fletcher, 2014). Samtidig viser de, at gode organisatoriske beslutninger og rammer $\mathrm{kan}^{1}$ modvirke stress og styrke genopladning.

I forbindelse med forskningsprojektet har vi præsenteret resultaterne for de deltagende og flere andre forbund, været i dialog med atleter, trænere og ledere om resultaterne og igangsat sportspsykologiske forløb med fokus på stress og genopladning. På baggrund af litteraturen, de konkrete resultater fra dette projekt og vores dialoger i dansk elitesport har vi udviklet en række anbefalinger. Vi anbefaler, at den sportslige ledelse og trænerne (1) skaber rammer, hvori unødig stress undgås, herunder god indkvartering, god mad og gode træningsmuligheder, (2) inddrager atleterne i planlægning og giver dem indflydelse, (3) prioriterer tid til genopladning og inkluderer det i programmet, (4) prioriterer medrejsende fysioterapeut og sportspsykolog, (5) hjælper atleterne med at "rydde bordet" hjemmefra og derved holde fokus og (6) evaluerer træning og konkurrence med atleterne for at reducere usikkerhed og tankemylder. Vi 
anbefaler sportspsykologer, at de (1) hjælper atleterne med at kortlægge individuelle stressorer og hensigtsmæssige genopladningsstrategier i god tid inden mesterskaber, (2) overvåger atleterne stress-genopladningsbalance under træningslejre og mesterskaber med henblik på at kunne intervenere tidligt ved uhensigtsmæssigheder og (3) hjælper atleterne med at være til stede i nuet, acceptere svære følelser og sætte præstationer i perspektiv. Vi anbefaler atleterne, at de (1) forholder sig nysgerrigt til deres individuelle stressorer og til hvilke genopladningsstrategier, der virker for dem, (2) laver en bevidst plan for genopladning under træningslejre og konkurrencer og prioriterer den, særligt når de oplever, der ikke er tid, og (3) suger energi fra fællesskabet og fra deres successer. Vores ønske er at fremtidige interventionsprojekter systematisk tester disse anbefalinger med henblik på at validere, forkaste eller udvikle dem yderligere.

\section{Litteratur}

Beckmann, J., \& Kellmann, M. (2004). Self-regulation and recovery: Approaching an understanding of the process of recovery from stress. Psychological Reports, 95, 1135-1153.

Bishop, P.A., Jones, E., \& Woods, A.K. (2008). Recovery from training: A brief review. Journal of Strength \& Conditioning Research, 22(3), 1015-1024.

Braun, V., Clarke, V., \& Weate, P. (2017). Using thematic analysis in sport and exercise research. I B. Smith \& A. Sparkes C. (Eds.), Routledge handbook of qualitative research in sport and exercise (pp. 191-205): Routledge.

Brink, M.S., Visscher, C., Coutts, A.J., \& Lemmink, K.A.P.M. (2012). Changes in perceived stress and recovery in overreached young elite soccer players. Scandinavian Journal of Medicine \& Science in Sports, 22(2), 285-292.

Davis, H., Orzeck, T., \& Keelan, P. (2007). Psychometric item evaluations of the recovery-stress questionnaire for athletes. Psychology of Sport \& Exercise, 8(6), 917-938.

Elbe, A.-M. (2008). The Danish version of the recovery-stress questionnaire for athletes. Unpublished Manuscript, University of Copenhagen, Denmark.

Elbe, A.-M., \& Kellmann, M. (2007). Recovery following training and competition. I B. Blumenstein, R. Lidor, \& G. Tenenbaum (Eds.), Psychology of sport training: Perspectives on sport and exercise psychology, 2 (pp. 162-185). Aachen: Meyer \& Meyer. Filho, E., di Fronso, S., Forzini, F., Agostini, T., Bortoli, L., Robazza, C., \& Bertollo, M. (2013). Stress/recovery balance during the Girobio: Profile of highly trained road cyclists. Sport Sciences for Health, 9(3), 107-112. 
Fletcher, D., \& Wagstaff, C. (2009). Organizational psychology in elite sport: Its emergence, application and future. Psychology of Sport and Exercise, 1o(4), 427-434.

Gustafsson, H., Hassmén, P., Kenttä, G., \& Johansson, M. (2008). A qualitative analysis of burnout in elite Swedish athletes. Psychology of Sport \& Exercise, 9(6), $800-816$.

Gustafsson, H., Skoog, T., Davis, P., Kenttä, G., \& Haberl, P. (2015). Mindfulness and its relationship with perceived stress, affect, and burnout in elite junior athletes. Journal of Clinical Sport Psychology, 9(3), 263-281.

Hansen, M.B., Henriksen, K., Johansen, L., \& Jørgensen, M. (2014). Team Danmark Restitutionskoncept. Retrieved from http://www.teamdanmark.dk/Eksperter/ Fysisk-traening/Restitutionskoncept.aspx

Henriksen, K., Stambulova, N., \& Roessler, K.K. (2010). Holistic approach to athletic talent development enviroments: A successful sailing milieu. Psychology of Sport \& Exercise, 11, 212-222.

Jurimae, J., Maestu, J., Purge, P., \& Jurimae, T. (2004). Changes in stress and recovery after heavy training in rowers. Journal of Science \& Medicine in Sport, 7(3), 334-339.

Kalda, J., Jurimae, T., \& Jurimae, J. (2004). Relationship between recovery-stress state and performance in sprint and jumpers. Perceptual \& Motor Skills, 99, 12-16.

Kellmann, M. (2002). Underrecovery and overtraining: Different concepts - similar impact? I M. Kellmann (Ed.), Enhancing recovery: preventing underperformance in athletes (pp. 3-24). Champaign, IL: Human Kinetics.

Kellmann, M. (2010). Preventing overtraining in athletes in high-intensity sports and stress/recovery monitoring. Scandinavian Journal of Medicine \& Science in Sports, 20(2), 95-102.

Kellmann, M., \& Kallus, K.W. (2001). Recovery-stress questionnaire for athletes: User manual. Champaign, IL: Human Kinetics.

King, D., Clark, T., \& Kellmann, M. (2010). Changes in stress and recovery as a result of participating in a premier rugby league representative competition. International Journal of Sports Science \& Coaching, 5(2), 223-237.

Ramian, K. (2012). Casestudiet i praksis: Hans Reitzels Forlag.

Ryba, T.V., Stambulova, N.B., Si, G., \& Schinke, R.J. (2013). ISSP Position Stand: Culturally competent research and practice in sport and exercise psychology. International Journal of Sport and Exercise Psychology, 11(2), 123-142.

Sarkar, M., \& Fletcher, D. (2014). Psychological resilience in sport performers: A review of stressors and protective factors. Journal of Sports Sciences, 32(15), 1419-1434.

Schinke, R.J., \& Stambulova, N.B. (2017). Context-driven sport and exercise psychology practice [Special issue]. Journal of Sport Psychology in Action, 8(2), 5. 


\title{
KAPITTEL 3
}

\section{Mestrer jeg trenerrollen?}

\section{Validitet og reliabilitet i en skala til måling av mestringstro i et utvalg norske breddefotballtrenere}

\author{
Yngvar Ommundsen ${ }^{1,2 \star}$, Bård Erlend Solstad', \\ Rune Høigaard ${ }^{2} \&$ Bente Wold ${ }^{3}$ \\ ${ }^{1}$ Norges idrettshøgskole, Seksjon for coaching og psykologi; ${ }^{2}$ Universitetet \\ i Agder, Institutt for folkehelse, idrett og ernæring; ${ }^{3}$ Universitetet i Bergen, \\ HEMIL-senteret, Det psykologiske fakultet
}

\begin{abstract}
Sammendrag: Formålet med denne studien var å teste dimensjons-, konvergens -, diskriminant- og kriterievaliditet for en norsk versjon av Feltz, Chase, Moritz og Sullivan (1999) Coaching Efficacy Scale. Invarians over tid og mellom grupper ble også inkludert med tanke på prospektiv bruk av skalaen i form av lengdesnittstudier og effektstudier. Utvalget omfattet 281 norske breddefotballtrenere i tre norske fotballkretser. Disse deltok i datainnsamlinger før (T1) og etter sesong (T2) i den norske delen (Solstad, 2017) av det internasjonale PAPA-prosjektet (Quested et al., 2013). Innledende eksplorativ faktoranalyse i Mplus støttet en forventet 4-faktors mestringstromodell som reflekterte henholdsvis: Motivasjon, Kampstrategi, Teknikk og Karakterbygging. To utsagn viste høy residualvarians og ble eliminert. En oppfølgende analyse basert på 22 utsagn gav tilfredsstillende tilpasningsindekser (S-B $\chi^{2}=[d f=149, n=222]$ $=312.901, p<.001 ;$ RMSEA $=.070 ; 90 \%$ konfidensintervall $(\mathrm{CI}=.059-.081)$; CFI $=.94$; SRMR $=.025$ ). Ved parselleringsteknikk (Kline, 2011; Little, Rhemtulla, Gibson, \& Schoemann, 2013) ble 22 utsagn konvertert til elleve parseller som basis for sjekk av faktorvaliditet og invarians over tid og mellom grupper ved hjelp av latent variabelanalyse. De elleve parsellene gav svært gode tilpasningsindekser; (S-B $\chi 2=[d f=29, n=222]=38.622, p<.011$ (ns.); RMSEA = .039; $90 \%(\mathrm{CI}=.000-.068)$; CFI $=.99$; SRMR $=.023)$. I tillegg fant vi entydig støtte for sterk skaleringsinvarians over tid (fotballsesongen; T1-T2) for intervensjons- og kontrollgruppe samlet. Invarians splittet på intervensjons-/kontrollgruppe kunne derimot ikke påvises. Vi observerte også god konvergent og diskriminerende validitet. Kriterievaliditet ble også bekreftet. I sum synes skalaen å være velegnet til undersøkelse av tverrsnitt- og lengdesnittstudier av treneres mestringstro i barne- og ungdomsidrett. Skalaen trenger ytterligere validering før bruk i intervensjonsstudier.
\end{abstract}

Nøkkelord: treneres mestringstro, skalavalidering, breddefotball

\footnotetext{
${ }^{*}$ Korresponderende forfatter: Yngvar Ommundsen, Norges idrettshøgskole, Seksjon for coaching og psykologi, Postboks 4014 Ullevål stadion, 0806 Oslo. Epost: yngvar.ommundsen@nih.no

Sitering av denne artikkelen: Ommundsen, Y., Solstad, B.E., Høigaard, R. \& Wold, B. (2018). Mestrer jeg trenerrollen? Validitet og reliabilitet i en skala til måling av mestringstro i et utvalg norske breddefotballtrenere. I T. Haugen \& R. Høigaard (red). Trender i idrettspsykologisk forskning i Skandinavia (Kap. 3, s. 47-72). Oslo: Cappelen Damm Akademisk. DOI: https://doi.org/10.23865/noasp.39.ch3

Lisens CC-BY 4.0
} 


\begin{abstract}
The purpose of this study was to examine factorial, convergent, discriminant, and criteria validity of a multi-dimensional scale measuring coaching efficacy (Feltz, Chase, Moritz, \& Sullivan, 1999). The sample consisted of 281 Norwegian grassroot football coaches taking part in two data collections (across the football season) within the Norwegian arm of the international PAPA project (intervention group, $n=193$ ) and control group, $n=88$ ). Latent variable modeling supported a 4-factor model reflecting Motivation efficacy, Strategy efficacy, Technique efficacy and Character efficacy. An introductory ESEM analysis of the 24-item coaching efficacy scale yielded an acceptable solution after omitting two items. A parceling approach of the twenty-two items were then converted into eleven parcels to examine factorial validity and time and group invariance. The four-factor model based on parcels obtained good fit indices: $\left(\mathrm{S}-\mathrm{B} \chi^{2}=[d f=29, n=222]=38.622, p<.011\right.$ (ns.); RMSEA $=.039 ; 90 \%(\mathrm{CI}=.000-.068)$; $\mathrm{CFI}=.99$; SRMR $=.023)$. Moreover, we obtained strong support for time invariance for a merged solution of the two groups of coaches. Invariance across time for the intervention and control group separately was supported at time 1 , but not at time 2 . Satisfactorily convergent, discriminant, and criteria validity were also supported. The scale needs further validation before use in intervention studies.
\end{abstract}

Keywords: coaching efficacy, scale validation, grassroot football

\title{
Introduksjon
}

Mestringstro (efficacy) har vært definert som en persons tro på egne ferdigheter i å planlegge og gjennomføre ulike typer handlinger for å nå mål (Bandura, 1997). Mestringstro genereres via sosial læring gjennom individets interaksjon med seg selv og sine sosiale og fysiske omgivelser (Bandura, 1997). Forskning har vist at mestringstro bidrar til økt motivasjon, høyere målsettinger, økt anstrengelse og dermed bedre resultater (Benight \& Bandura, 2004; Feltz, Short, \& Sullivan, 2008). Teorien om mestringstro har blitt applisert spesifikt på ulike individuelle roller, områder og grupper (dvs. studenters mestringstro, mestringstro blant lærere og kollektiv mestringstro; Bandura, 1997; Feltz et al., 2008).

Feltz et al. (1999) utviklet en skala til måling av mestringstro i rollen som trener. Den er integrert i en modell hvor innholdet i mestringstro spesifiseres, samt forløpere og konsekvenser. Skalaen måler fire dimensjoner: Motivasjon, Kampstrategi, Teknikk og Karakterbygging. «Motivasjon» inkluderer tillit til at man kan motivere og influere på psykologiske ferdigheter og tilstander blant egne utøvere. «Kampstrategi» er knyttet til strategisk tenkning og valg, og innebærer tiltro til at man i konkurranser evner å lede egne utøvere til gode prestasjoner. «Teknikk» er troen på at en har tiltro til egne ferdigheter som trener, og det er knyttet til å instruere, diagnostisere og veilede samt demonstrere gode ferdighetsbilder i egen idrett. Og «Karakterbygging» er å 
ha tiltro til egen evne til å få utøverne til å tenke og handle i tråd med gode etiske retningslinjer (f.eks. fair play) når de utøver idretten sin.

Trenere som har sterk tiltro til det å kunne motivere, foreta taktiske valg, formidle tekniske ferdigheter samt formidle betydningen av god sportsånd, vil merke påvirkning på egen motivasjon og atferd, noe som i sin tur påvirker utøvernes tankemønstre, følelser og atferd (Feltz et al., 1999; Mageau \& Vallerand, 2003). Forskning har vist at trenere som opplever høy mestringstro i rollen som trenere, synes å være mer tilbøyelige til å lede på en måte som er til beste for utøverne (Feltz et al., 1999; Sullivan, Paquette, Holt, \& Bloom, 2012; Sullivan \& Kent, 2003). Det er for eksempel vist at lederskap preget av mestringstro evner å skape indre motivasjon blant utøverne og forebygge frafallet i organisert idrett (Hollembeak \& Amorose, 2005; Pelletier, Fortier, Vallerand, \& Briere, 2001).

\section{En skala om treneres mestringstro - psykometriske kvaliteter}

I de senere årene har skalaen for måling av mestringstro for trenere gjennomgått utstrakt psykometrisk testing (for en oversikt, se Myers, Chase, Pierce, \& Martin, 2011). Tidlige tester av skalaens modelltilpasning viste i flere tilfeller uakseptable verdier; eksempelvis .87-.89 for CFI og .o8-.09 for RMSEA. Spesielt så man dette i studier blant idrettsutøvere innen amerikansk idrett på videregående/gymnasnivå (Feltz et al., 1999). Samtidig viser senere valideringsforsøk på tilsvarende utvalg noe bedre resultater (for en oversikt, se Myers, Feltz, \& Wolfe, 2008; Myers et al., 2011).

Mestringstro i trenerrollen har fått overraskende lite oppmerksomhet blant trenere i barne- og ungdomsidretten (Feltz, Hepler, Roman \& Paiement, 2009; Myers et al., 2008). Feltz et al. (2009) undersøkte psykometriske egenskaper ved skalaen på et utvalg amerikanske ungdomsidrettstrenere, hvor de fant blandet støtte for skalaens faktorvaliditet ved bruk av latent variabelanalyse (bekreftende faktoranalyse, CFA). En mer nylig kanadisk studie innen barne- og ungdomsidretten undersøkte betydningen av idretts-/veiledningskonteksten og trenernes formelle utdanning for deres mestringstro, og hvordan en slik forventning var forbundet med deres opplevelse av hvordan de veiledet og ledet utøverne sine (Sullivan et al., 2012). Resultatene viste at formell trenerutdanning 
er av betydning for deres tro på det å motivere, foreta taktiske valg, formidle tekniske ferdigheter samt formidle betydningen av god sportsånd. I den studien målte man imidlertid mestringstro overordnet, ikke på de respektive fire nevnte dimensjonene. Dermed får man liten innsikt i hvordan trenerutdanning eksplisitt påvirker for eksempel tiltro til å motivere versus tiltro til ferdighet i å foreta taktiske valg i møte med utøverne.

\section{Mestringstroskalaen for trenere behøver ytterligere validering}

Horn (2002) har pekt på at utvidet validering av skalaen innenfor rammen av barne- og ungdomsidrett åpner opp for en mer inngående undersøkelse av psykologiske faktorer og prosesser som kan påvirke idrettsdeltakelsen, sett både fra utøvernes ståsted og fra trenerne selv. Uavhengig av nylige forsøk på bruk av skalaen og testing av dens psykometriske egenskaper i andre kulturelle kontekster (Malete, Chow, \& Feltz, 2013) synes det viktig å validere skalaen til bruk her i landet. Det finnes i det hele tatt lite validering og bruk av skalaen i en europeisk idrettskontekst, og formålet med denne studien er derfor å undersøke den psykometriske kvaliteten ved den norske versjonen av Feltz et al. (1999) - Coaching Efficacy Scale.

Innen psykologisk forskning pågår det en debatt vedrørende metodikk i forbindelse med språklig og kulturell oversettelse av denne type skalaer. Dette er problemstillinger som ofte underkommuniseres blant forskere (Segall, Lonner, \& Berry, 1998). I denne studien har vi forsøkt å vise transparens med hensyn til slike problemstillinger, og vi har fulgt anbefalte anvisninger i forbindelse med oversettelse og psykometrisk testing av skalaen i en norsk idrettskontekst (Byrne, 2012). Det innbefatter bl.a. stringent oversettelse og re-oversettelse fra engelsk til norsk (Epstein, Santo, \& Guillemin, 2015), samt bruk av ulike analyseformer for å undersøke validitet og reliabilitet.

\section{Invarians over tid og mellom grupper}

Undersøkelse av psykometrisk kvalitet innebærer også hvorvidt skalaen egner seg ved prospektive analyser og analyse av intervensjonseffekter. 
Følgelig tok vi et steg lenger enn hva tidligere forskning har gjort ved å teste den norske versjonen med hensyn til invarians over tid, samt invarians mellom to grupper (en intervensjonsgruppe og en kontrollgruppe) blant trenere som inngikk i den norske delen av det internasjonale PAPA-prosjektet (se utvalgskarakteristika for nærmere omtale).

Invarians i et måleinstrument er avgjørende ved test av endring i skårer over tid og/eller mellom grupper. Gjennomsnittsverdiene til latente faktorer kan ikke sammenliknes dersom måleinstrumentene ikke oppfyller kravene til faktorinvarians (Little et al., 2013; Sass, 2011). Tidligere studier har undersøkt i hvilken grad utdanningsprogrammer for trenere påvirker deres mestringstro (Campbell \& Sullivan, 2005; Malete \& Feltz, 200o), men så vidt oss bekjent testet ikke disse eller andre studier mestringstrodimensjonene for invarians over tid og/eller mellom grupper. Oppnår man invarians, kan man være rimelig sikker på at enhver påvist forskjell i skår på skalaen over tid og/eller mellom grupper er reell, og ikke en artefakt av manglende invarians. Rent overordnet innebærer invarians at utsagnene (observert nivå) som er underliggende for de fire latente dimensjonene i mestringstro, er homogene og stabile over tid og/ eller mellom grupper (Geiser, 2013; se statistisk analyse for ytterligere detaljer). Bare under slike betingelser kan man ha tiltro til resultatenes validitet (for en oversikt, se Geiser, 2013).

\section{Kriterievaliditet}

Kriterievaliditet ble sjekket ved å undersøke de fire dimensjonene av mestringstro opp mot trenernes positive emosjonelle tilstand i forbindelse med trenergjerningen. Rasjonalet for dette er basert på tidligere forskning, som har vist at eksperimentelt indusert økt mestringstro relatert til gjennomføring av fysisk aktivitet er assosiert med en økning i positive følelser etter å ha trent (Jerome et al., 2002; McAuley, Talbot, \& Martinez, 1999). I og med at selvrapportert vitalitet i dagliglivet kan tilsløre forholdet mellom mestringstro i rollen som trener og trenerens positive emosjonelle tilstand i trenerrollen, kontrollerte vi for vitalitet i dagliglivet. 


\section{Metode}

\section{Deltakere}

Utvalget bestod av 281 norske trenere innen breddefotball fra tre norske fotballkretser (menn $n=258$, kvinner $n=23$ ). Gjennomsnittsalder var 42 år $(S D=6,1$ år); aldersintervall fra 16 til 60 år. De var hovedsakelig etnisk norske (94\%). Trenerne hadde ulike roller i eget fotballag; hovedtrenere $(n=44)$, assistenttrenere $(n=86)$, trenere med delt ansvar $(n=71)$ og 19 trenere som rapporterte andre varianter av ansvarsfordeling, samt 61 trenere som ikke oppgav noe vedrørende egen rollefunksjon i laget. Gjennomsnittlig erfaring som trener var 7 år ( $S D=4,9$ år); og gjennomsnittlig antall år som trener for nåværende lag var 4,3 år $(S D=2,1$ år). Når det gjaldt formell trenerutdanning, rapporterte $48 \%$ av totalutvalget en viss formell trenerutdanning (grovt rangert som lavt, medium og høyt nivå). $52 \%$ svarte ikke på dette spørsmålet. Utvalget ble randomisert delt inn i en intervensjonsgruppe $(n=193)$ og en kontrollgruppe $(n=88)$. Datainnsamlingen og utvalget var integrert i den norske delen av det internasjonale Promoting Adolescent Physical Activity-prosjektet (PAPA) (Duda et al., 2013). PAPA er et intervensjonsprosjekt med mål om å stimulere til økt motiverende lederskap blant trenere i den organiserte breddefotballen blant barn og unge (Quested et al., 2013; Solstad, Van Hoye, \& Ommundsen, 2015). Påvirkning av treneres mestringsforventning var ikke et formalisert formål med det internasjonale PAPA-prosjektet (Quested et al., 2013). I den norske delen av datainnsamlingen ble imidlertid treneres mestringstro i trenerrollen lagt til i spørreskjemaet med tanke på evaluering av måleinstrumentet på norsk, samt med tanke på en eventuell endring av slik mestringstro som følge av intervensjonen. Et teoretisk rasjonale for dette er dokumentert i tidligere forskning ved at kontekstuell stimulering kan gi næring til et mestringsfokusert målperspektiv med positive implikasjoner på egen tiltro til å mestre ulike oppgaver i rollen som trener (Duda \& Nicholls, 1992; Jourdan, Bandura, \& Banfield, 1991). En validering av instrumentet i en norsk idrettskontekst åpner også opp for bruk i eventuelle framtidige studier som ønsker å undersøke treneres mestringstro i rollen som trener. 


\section{Framgangsmåte}

Før rekruttering av fotballklubber til prosjektet ble datainnsamlingen blant trenere og spillere godkjent av NSD (Norsk senter for forskningsdata). Trenere i disse klubbene, som hadde lag i breddefotballen i aldersintervallet 11-14 år, ble invitert til å delta. Begge datainnsamlingene ( $\mathrm{T}_{1}$ og $\mathrm{T} 2$ ) ble gjennomført etter forhåndsavtale med trenerne før eller etter en trening med laget, eller på et annet passende tidspunkt for dem. Trenerne ble skriftlig og muntlig orientert om hva deltakelse i prosjektet innebar, og informert om at de når som helst kunne trekke seg. Datainnsamlingen foregikk ved at trenerne fylte ut standardiserte spørreskjemaer.

\section{Måleinstrumenter}

\section{Demografiske bakgrunnsdata}

Det ble innhentet data for alder, kjønn, etnisitet og fotballbakgrunn (trener og som spiller), og med spesifisert informasjon om trenergjerningen. Dette inkluderte trenererfaring (nåværende og tidligere lag), antall år som trener, type lag, formell trenerutdanning (kurs, sertifisering), samt ansvarsfunksjon i eget lag.

\section{Treneres mestringstro}

En norsk versjon av Coaching Efficacy Scale (Feltz, et al., 1999) ble benyttet for å måle treneres mestringsforventning. Skalaen består av 24 utsagn og skiller mellom fire ulike kategorier av mestringstro: Motivasjon (dvs. tro på egen evne til å motivere egne spillere), Kampstrategi (dvs. tro på egen evne til å foreta taktiske valg), Teknikk (dvs. tro på egen evne til utvikle tekniske ferdigheter) og Karakterbygging (dvs. tro på egen evne til å formidle betydningen av god sportsånd). Utsagnene fra den originale versjonen ble modifisert med sikte på å knytte mestringstro spesifikt til trenerrollen i breddefotballen for barn og unge. Således ble de fire aspektene ved mestringstro knyttet spesifikt til deres forventning om å mestre dette overfor spillere i eget fotballag. Det innebar at «utøvere» ble erstattet med «spillere» i alle utsagnene, og inngangen til utsagnene var følgende: Alle trenere er ulike med hensyn til hva de føler at de gjør bra eller dårlig sammen med laget 
sitt. Sett ring rundt det tallet som representerer hvor stor tro du har på dine evner med tanke på de ulike ferdighetene som står under, fulgt opp av: Hvor stor tro har du på at du kan. På linje med Feltz et al. (1999) ble alle utsagnene besvart på en responsskala fra o (ingen tro) til 9 (svoert stor tro). Da instrumentet ble brukt første gang i en norsk idrettskontekst, gjennomgikk det en engelsk-norsk oversettelse og re-oversettelse ved hjelp av kyndige tospråklige personer med innsikt i tematikken. Målet med oversettelsesprosedyren var å reflektere meningsinnholdet i den engelske versjonen (kilden), snarere enn å foreta en bokstavelig oversettelse av ordbruken i kildeversjonen (Epstein et al., 2015; Su \& Parham, 2002).

\section{Positiv affektiv tilstand}

En kortversjon (seks utsagn) av The Positive and Negative Affect Schedule (PANAS) ble benyttet (Watson, Clark, \& Tellegen, 1988). Skalaen ble tilpasset fotballkonteksten via inngangssetningen: Sett en ring rundt det svaret som passer best med hvor ofte de følgende følelsene har preget deg når du har trent dette laget $i$ løpet av den siste måneden, etterfulgt av: I løpet av den siste måneden mens jeg har trent dette laget, har jeg stort sett følt meg: (a) glad, (b) lykkelig, (c) oppstemt, (d) begeistret/frydefull, (e) entusiastisk, og (f) stolt. En syvpunkts responsskala fra 1 (sjelden/aldri) til 7 (alltid) ble benyttet.

\section{Vitalitet}

Vi anvendte en fempunkts utsagnsskala basert på arbeidet til Ryan og Frederick (1997), som måler vitalitet i dagliglivet. Inngangen til skalaen var: Under står noen utsagn relatert til hverdagslivet ditt (alt du vanligvis gjør) og ikke bare til fotballgjerningen din. Sett en ring rundt svarene som passer best med hvordan du generelt har kjent deg den siste måneden, etterfulgt av: Den siste måneden har jeg stort sett: (a) følt meg opplagt, (b) vært i godt humør, (c) gledet meg til hver dag, (d) følt meg kvikk og våken, og (e) hatt masse energi.

\section{Statistiske analyser}

I tråd med anbefalinger (Kline, 2011) anvendte vi eksplorativ faktoranalyse (ESEM; Mplus versjon 8.o) i en innledende fase på den opprinnelige 
24-punkts utsagnskalaen med mål om avklaring av beste tilpasning (en faktor versus 2-, 3- eller 4-faktorløsning), etterfulgt av sjekk av faktorladninger samt residualvarians. Vi anvendte deretter bekreftende faktoranalyse (CFA) med estimering av maksimal sannsynlighet (robust maximum likelihood estimation; MLR-estimator) på en utsagnsløsning med tilfredsstillende estimater avdekket i ESEM-analysen.

\section{Parsellering}

Vi tok i bruk parsellering ved måling av faktorvaliditet og invarians. Dette innebærer at hvert enkelt utsagn deles opp i ikke-overlappende enheter, eller sett av utsagn (Kline, 2011). Det skjer via en totrinnsprosess (total disaggregering; Bagozzi \& Edwards, 1998) hvor utsagnene først aggregeres til parseller som hver består av to eller flere utsagn. Deretter anvendes de aggregerte utsagnene som manifeste indikatorer for et latent begrep i en flerdimensjonal målemodell (delvis disaggregering; Bagozzi \& Edwards, 1998). I motsetning til å operere med enkelt-utsagn som manifeste variabler, har bruk av parseller som manifeste variabler følgende fortrinn: (a) færre parametere som skal estimeres, (b) lavere indikator-til-deltaker-ratio, (c) mindre sannsynlighet for korrelerte restledd (residualer), og (d) doble faktorladninger samt færre kilder som kan forårsake utvalgsfeil (for en oversikt, se Little et al., 2013). Parsellering bidrar til å redusere kompleksiteten i målemodeller og strukturmodeller som inkluderer flere latente begreper; modeller som ellers kan vise seg for komplekse til at de lar seg estimere. Dette krever imidlertid at man innen hver parsell opererer med endimensjonale begrep (Kline, 2011, Little et al., 2013). Av den grunn brukte vi som nevnt først ESEM-analyse for å bekrefte grunnstrukturen (4-faktorløsning) i mestringstroskalaen. Little et al. (2013) har argumentert for en tilnærming ved opprettelse av parseller hvor disse forsøkes balansert (dvs. the balancing approach). Hovedhensikten er å få en mest mulig balansert representasjon av de ulike utsagnenes styrke til å representere det latente begrepet. Operativt gjøres det ved at man lager par av utsagn som har henholdsvis høyest og lavest faktorladning, nest høyest og nest lavest osv. (Little et al., 2013). 
Modelltilpasningen for de fire dimensjonene ved mestringstro Motivasjon, Kampstrategi, Teknikk og Karakterbygging - ble undersøkt ved hjelp av en kji-kvadrattest (Satorra-Bentler chi-square test; S-B $\chi^{2}$ difference test; for en oversikt, se Satorra \& Bentler, 2001), sammenliknende tilpasningsindeks (CFI, Bentler, 1990), standardisert kvadratrot-residual (SRMR; Bentler, 1995), tilnærmet kvadratrot-basert feilestimat (RMSEA; Browne \& Cudek, 1993), med tilhørende 90\% konfidensintervall rundt RMSEA. Generelt reflekterer RMSEA verdier nært opp til .o6 (Hu \& Bentler, 1999) akseptabel tilpasning, og verdier lik eller mindre enn .05 god tilpasning (Browne \& Cudek, 1993). CFI-verdier lik .95 eller over, og SRMR verdier mindre enn eller lik .08 speiler en tilstrekkelig modelltilpasning til data (Hu \& Bentler, 1999; Marsh, Wen, \& Hau, 2004).

\section{Invarians over tid og/eller mellom grupper}

Prospektive analyser (endringsanalyser) av mestringstro betinger invarians over tid av de målingene som gjøres. Invarians innebærer sammenlikning av en serie nestete modeller, hvor man suksessivt pålegger dem flere restriksjoner (Dimitrov, 2010). Konfigurativ invarians reflekterer at det er konsistens over tid og/eller mellom grupper i antallet indikatorer tilhørende et latent begrep, samt at korrespondansen mellom indikator og latent begrep er lik over tid. Metrisk invarians speiler hvorvidt ladningene som tilhører de respektive indikatorene for et latent begrep, er like over tid og/eller mellom grupper. Skaleringsinvarians speiler hvorvidt innslags-/avskjæringspunktet (intercept) for de respektive indikatorene er likt over tid og/eller mellom grupper. Serien av nestete modeller med suksessivt flere restriksjoner blir så sammenliknet for tilpasning. Endringer i tilpasningsindekser over de tre nivåene konfigurativ, metrisk og skaleringsinvarians anses akseptabel og indikerer invarians ved ikke-signifikant endring i kji-kvadrat, samt $\Delta \mathrm{CFI} \leq$.o1 og $\triangle \mathrm{RMSEA} \leq$.015) ved å sammenlikne tilpasningsindeksene mellom de ulike invariansnivåene (for en oversikt, se Chen, 2007; Cheung \& Rensvold, 2002). 


\section{Konvergent og diskriminant validitet samt kriterievaliditet}

Vi testet konvergent validitet gjennom å sjekke størrelse og signifikansnivå for koeffisientene på de respektive observerte parsellene under de fire latente begrepene for mestringstro (Cole, 1987). Signifikante verdier på de parselleringsbaserte koeffisientene indikerer god konvergent validitet. I tillegg så vi også på størrelsen på koeffisientene (dvs. faktorladningene). Vi testet diskriminantvaliditet ved inspeksjon av korrelasjoner mellom de fire ulike dimensjonene av mestringsforventning. Korrelasjonsstørrelse $<.85$ er tegn på tilstrekkelig diskriminerende validitet (Kline, 2011). Test av diskriminerende validitet ble supplert ved hjelp av en mer sofistikert tilnærming (Fornell \& Larker, 1981; se resultatdel for en mer utfyllende beskrivelse). Kriterievaliditet ble testet ved hjelp av partiell korrelasjonsanalyse av enkle sumskårer i SPSS.

\section{Reliabilitet}

Reliabilitetskår av skalaen ble estimert ved hjelp av sammensatt reliabilitet (Composite reliability; Raikovs Rho) i Mplus. Fordelen med denne er at den ikke betinger at alle utsagnene bidrar likt til faktorvarians. Samtidig tar Raikovs Rho høyde for korrelert feilvarians (Yang \& Green, 2010).

\section{Manglende data}

Av 281 trenere fylte 222 ut spørreskjemaet ved T1 og 204 ved T2. Vi fikk data fra 145 både ved $\mathrm{T}_{1} \mathrm{og}$ ved $\mathrm{T} 2$, mens 77 trenere fylte ut spørreskjemaet kun ved $\mathrm{T}_{1}$ og 59 trenere kun ved T2. Imidlertid aksepterte alle trenerne i utvalget vår invitasjon om å delta både ved $\mathrm{T}_{1}$ og ved $\mathrm{T}_{2}$, og det var ingen som trakk seg fra studien. Ingenting tyder på at manglende data (dvs. missing data analysis) skyldes annet enn organisasjonsmessige forhold knyttet til datainnsamlingene, som f.eks. lang reiseavstand for de som hadde ansvaret for datainnsamlingen, samt at trenere i flere tilfeller ikke så seg i stand til å tilpasse endrede tidspunkter initiert 
av de som samlet inn data, eller at de selv - grunnet uforutsette faktorer ikke kunne møte til avtalt tid for datainnsamling med laget sitt. Av den grunn anså vi data som manglende ved tilfeldighet (missing at random; MAR), og vi anvendte derfor analysen Full Information Maximum Likelihood (FIML). Den betraktes som overlegen andre tradisjonelle teknikker ved at den tar i bruk alle datapunkter og genererer fullverdig informasjon for tilpasning til en statistisk modell basert på alle tilgjengelige data (Little et al., 2013). FIML betraktes dessuten som effektiv med hensyn til å redusere skjevhet grunnet ikke-tilfeldig oppstått manglende data (missing not at random; MNAR), og den evner å gi reliable analyseresultater selv ved en sats på 60\% manglende data (for en oversikt, se Dong \& Peng, 2013).

\section{Resultater}

\section{Beskrivende statistikk}

Gjennomsnittsverdier, standardavvik og estimater for sammensatt reliabilitet for de fire dimensjonene av mestringstro, positive følelsestilstander og vitalitet i dagliglivet er gjengitt i Tabell 1.

Tabell 1. Beskrivende statistikk, reliabilitetsestimater og estimater vedrørende diskriminerende validitet (AVE).

\begin{tabular}{|l|c|c|c|c|}
\hline & Gj.snitt & SD & composite RHO\# & AVE skår \\
\hline MT: Motivasjon & 7.14 & 0.92 & .92 & 0.64 \\
\hline MT: Karakterbygging & 7.73 & 0.93 & .90 & 0.70 \\
\hline MT: Kampstrategi & 6.30 & 1.20 & .90 & 0.58 \\
\hline MT: Teknikk & 6.81 & 1.17 & .92 & 0.67 \\
\hline Positive følelser & 5.66 & 0.79 & .88 & * \\
\hline Vitalitet & 3.89 & 0.63 & .92 & $*$ \\
\hline
\end{tabular}

Note. *ikke relevant; \#utsagnsbasert RHO; MT = mestringstro.

Sammensatt reliabilitet var tilfredsstillende med Raikovs Rhokoeffisienter i størrelsesorden fra .9o til .92. Trenerne rapporterte relativt høy mestringstro, høyest for Karakterbygging og lavest for Kampstrategi. 
En enveis variansanalyse i SPSS med oppfølgende Tukey-b post-hoc-test viste signifikant høyere skår på teknisk mestringstro blant trenere med middels $(M=7.04)$ eller høyere nivå av formell trenerutdanning $(M=7.08)$, sammenliknet med gruppen lav $(M=6.05)$. Ingen forskjeller kunne påvises for de andre dimensjonene. En t-test for uavhengige utvalg ble brukt for å undersøke forskjeller i mestringstro mellom trenere som oppgav ulike roller i eget lag (dvs. hovedtrener og likt ansvar versus assistenttrener). Resultatene viste at trenere med hovedansvar eller delt ansvar skåret signifikant høyere på mestringstro relatert til Teknikk $(t=4.40, p<.001)$, Motivasjon $(t=2.34, p<.01)$ og Kampstrategi $(t=2.71, p<.01)$ enn assistenttrenere (alle disse analysene ble foretatt i SPSS i en innledende fase basert på enkle summerte skårer på de fire dimensjonene av mestringstro).

Den 24-utsagnsbaserte 4-faktormodellen som bygget på ESEM-analyse, gav akseptabel tilpasning til data, men to utsagn - (a) finne ut av motstanderlagets sterke sider $i$ kamp, og (b) forberede spillerne mentalt på kamp ble tatt ut grunnet høy residual varians (se vedlegg, og se diskusjonsdel for legitimering). En modifisert ESEM-versjon basert på de gjenværende 22 utsagnene gav klart akseptabel tilpasning til data: $\left(\mathrm{S}-\mathrm{B} \chi^{2}=[d f=149, n=222]\right.$ $=312.901, p<.001 ; \mathrm{RMSEA}=.070 ; 90 \%$ (CI = 0.059-0.081); CFI = .94; SRMR $=.0025)$. GEOMIN-roterte faktorladninger var høye og signifikante; $\mathrm{i}$ størrelsesorden fra .46 til .89 på de respektive forventende utsagnene.

En CFA-versjon basert på den samme 22-utsagnsversjonen gav en akseptabel tilpasning til data: $\left(\mathrm{S}-\mathrm{B} \chi^{2}=[d f=203, n=222]=458.425\right.$, $p<.001 ;$ RMSEA $=.080 ; 90 \%(\mathrm{CI}=.066-.084)$; CFI $=.91 ; \mathrm{SRMR}=.066)$. Standardiserte faktorladninger var høye og signifikante, i størrelsesorden fra .70 til .89, og residualvarians var overveiende lav. Resultatene fra de innledende ESEM-analysene, og CFA-analysene, styrker konklusjonen om en samlet sett klart akseptabel tilpasning for 22-utsagnsmodellen, og kriteriet for å gå videre med en parselleringstilnærming synes å være til stede (Kline, 2011).

De elleve parsellene tilhørende henholdsvis dimensjonene mestringstro knyttet til å: (a) motivere, (b) foreta taktiske valg, (c) utvikle tekniske ferdigheter, samt (d) formidle betydningen av god sportsånd, basert på 22-utsagnsskalaen, gav svært gode tilpasningsindekser: $\left(S-B \chi^{2}=[d f=29\right.$, $n=222]=38.622, p<.011$ (ns.); RMSEA = .039; 90\% (CI = .000-.068); 
CFI $=$.99; SRMR $=$.023). Standardiserte faktorladninger for de ulike observerte skårene (parsellene) for den enkelte dimensjon ladet signifikant, sterkt og entydig på de respektive fire latente dimensjonene uten indikasjoner på bedre modelltilpasning ved tillegg av kryssladninger. Dette indikerer god begreps- eller dimensjonsvaliditet for skalaene. Det er også en indikator på god konvergerende validitet (Cole, 1987). Som vist i Figur 1 er de standardiserte vektene i størrelsesorden fra .81 til .96.

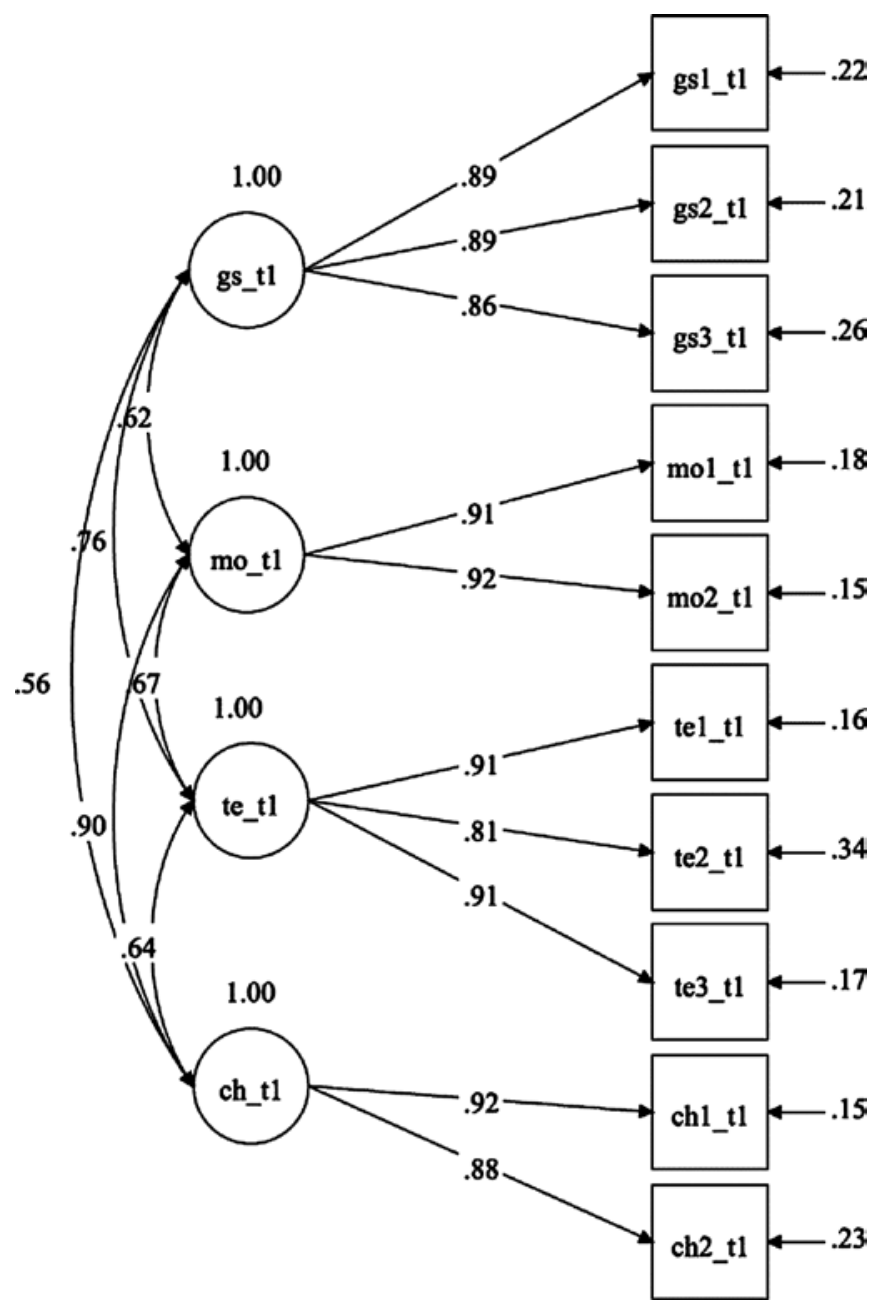

Figur 1. 22-utsagnsskala for mestringstro - faktorladninger, residualer og inter-korrelasjoner mellom dimensjoner.

Note. gs $=$ Kampstrategi; $\mathrm{mo}=$ Motivasjon; te $=$ Teknikk; $\mathrm{ch}=$ Karakterbygging . 
Videre viste resultatene at minst 50\% av variansen (69-93\%) for hver av de ti parsellbaserte observerte indikatorene forklares av modellen. Restleddene (residualene) er svært små - og størrelsesmessig jevnt fordelt. Sammen med tilpasningsindeksene og de standardiserte faktorladningene indikerer disse funnene at den teoretiske målemodellen har god tilpasning til data, og at de elleve parsellene dermed uttrykker god dimensjonsvaliditet og konvergerende validitet for de fire latente begrepene: Motivasjon, Kampstrategi, Teknikk og Karakterbygging (Anderson \& Gerbing, 1988; Cole, 1987; Kline, 2011).

Reliabilitetsestimater vises både via reliabilitetskårer og sammensatt reliabilitet (Raikovs Rho) i Tabell 1. Som også vist i Tabell 1 er estimatene for Raikovs Rho på mellom .90 og .92, med noe lavere verdier for reliabilitetskårene. I sum er det støtte for god relabilitet i de fire dimensjonene av mestringstro.

\section{Invarians over tid og gruppe}

Ifølge Tabell 2 viste resultatene entydig støtte til Konfigurativ invarians, Metrisk invarians og Skaleringsinvarians fra $\mathrm{T}_{1}$ til T2 for intervensjonsog kontrollgruppen samlet. Ingen endring i kji-kvadratverdier ble observert, CFI-verdiene forholdt seg høye, og RMSEA-verdiene forholdt seg lave, med kun marginale justeringer fra Konfigurativ invarians til Skaleringsinvarians $(\triangle \mathrm{CFI} \leq$.01, $\triangle \mathrm{RMSEA} \leq$.015).

Samlet indikerer dette invarians ved sammenlikning av de respektive nestete modellene (Chen, 2007; Cheung og Rensvold, 2002), og således støtte til Skaleringsinvarians. Det åpner dermed opp for at skalaen kan brukes til sammenlikning av gjennomsnittsverdier på skårer over tid (Dimitrov, 2010). Vi testet også gruppeinvarians (intervensjon/kontrollgruppe) på henholdsvis $\mathrm{T} 1$ og $\mathrm{T} 2$ (data ikke vist). I sum fant vi støtte for Skaleringsinvarians på $\mathrm{T} 1(\Delta \mathrm{CFI} \leq$.01, $\triangle \mathrm{RMSEA} \leq$.015), men ikke på T2, ifølge anbefalte retningslinjer, ved at CFI-verdien (.11) oversteg disse retningslinjene allerede i basismodellen (Chen, 2007; Cheung \& Rensvold, 2002). 


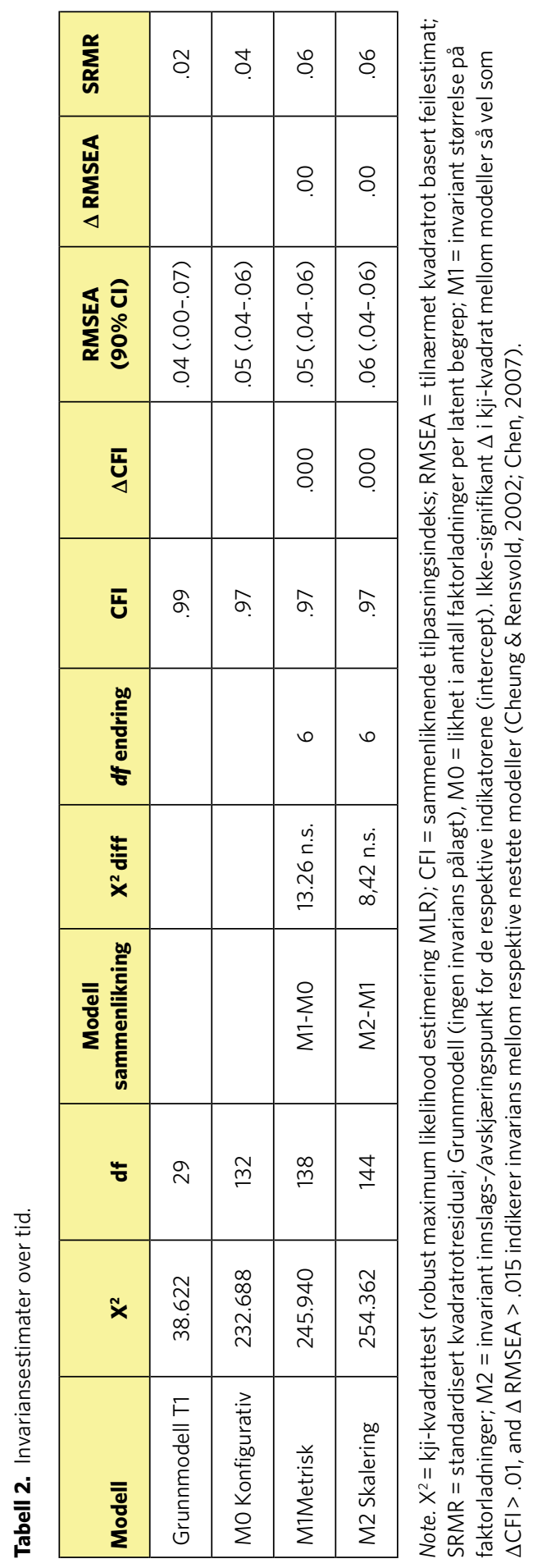




\section{Diskriminantvaliditet}

Som vist i Figur 1 er korrelasjonene mellom de fire latente dimensjonene i størrelsesorden fra .56 til .90. Med unntak av korrelasjonen mellom mestringstro vedrørende Motivasjon og Karakterbygging $(r=.90)$ er det ingen av de andre dimensjonene som overstiger grensekriteriet $(<.85)$ for tilfredsstillende diskriminerende validitet (Kline, 2011). Fornell og Larker (1981) beskrev imidlertid en mer stringent test for avklaring av dette. For at et begrepspar skal ha diskriminerende validitet, må gjennomsnittlig ekstrahert varians (AVE) for hver dimensjon i paret være større enn kvadratet av faktorkoeffisienten for de respektive dimensjonene. Kvadratet av faktorkoeffisienten for de respektive dimensjonene var i størrelsesorden fra 33 til .77. Bare kvadratet av koeffisienten til dimensjonene mestringsforventning om Motivasjon og Karakterbygging (.77) var større enn AVE for hver av de fire dimensjonene i Tabell 1 (område .64-.70). Oppsummert, selv ved bruk av denne mer sofistikerte tilnærmingen til måling av diskriminerende validitet, finner vi støtte for diskriminerende validitet mellom alle dimensjonene så nær som mellom mestringstro med henblikk på Motivasjon og Karakterbygging.

\section{Kriterievaliditet}

Pearsons korrelasjonsanalyse viste en positiv sammenheng mellom positiv affekt og alle de fire dimensjonene av mestringstro: Motivasjon $(r=.49$, $(r=.41), p<.001)$, Kampstrategi $(r=.34,(r=.31), p<.001)$, Teknikk $(r=.31,(r=.24), p<.001)$, og Karakterbygging $(r=.46,(r=.38), p<.001)$. Partiell korrelasjonsanalyse med kontroll for vitalitet i dagliglivet endret lite på korrelasjonsmønsteret (partielle korrelasjoner i parentes). Summert står de positive sammenhengene seg mellom alle de fire dimensjonene av mestringstro og positiv affekt i rollen som trener, også ved kontroll for egenrapportert følt vitalitet i dagliglivet blant trenerne.

\section{Diskusjon}

Formålet med denne studien var å undersøke måleegenskapene til den norske versjonen av skalaen til måling av mestringstro i rollen som trener 
(Feltz et al., 1999; 2009; Myers et al., 2008; Sullivan et al., 2012). Vi benyttet ESEM, etterfulgt av flere CFA-er på et utvalg norske trenere i organisert breddefotball. Vi testet måleegenskaper i form av dimensjons-, konvergens-, diskriminant- og kriterievaliditet for skalaen. I tillegg undersøkte vi skalaens reliabilitet.

ESEM-analysene viste høye residualer på utsagn 2 og 3. Byrne (2012) og Kline (2011) legitimerer modifiseringer av en teoretisk basert skala ved oversettelse dersom det kan gis et rasjonale for modifiseringene. I vårt tilfelle grunngis dette på et primært empirisk grunnlag gjennom høye residualer på de to utsagnene. For øvrig er vi av den oppfatning at utsagnene (a) finne ut av motstanderlagets sterke sider i kamp, og (b) forberede spillerne mentalt på kamp, med stor sannsynlighet oppfattes som relativt marginale blant de rolleforventninger som skal mestres for en trener med spillere i aldersklassen 11-14 år i norsk breddefotball. Slike utsagn har større relevans om man tenker seg at kampresultater og prestasjonsfokus står sentralt blant trenere i dette segmentet. Lite tyder på det, snarere synes det å være motsatt. En nylig studie viste at trenere i norsk breddefotball fokuserer på å ivareta mestring og sosial inklusjon i trenergjerningen (for en oversikt, se Solstad, 2017).

De innledende ESEM-analysene som er basert på 22 utsagn, viste god tilpasning til data: $\left(\mathrm{S}-\mathrm{B} \chi^{2}=[d f=149, n=222]=312.901, p<.001\right.$; RMSEA $=.070 ; 90 \%(C I=.059-.081) ; \mathrm{CFI}=.94 ;$ SRMR $=.025)$. Selv om tilpasningen ble noe moderert i CFA-modellen, ble den betydelig bedre der ved bruk av parseller. Det er vanskelig å sammenlikne våre funn med tidligere relevante studier (se for eksempel Feltz et al., 2009), da det er forskjeller i analysetilnærminger, responsskalering og i hva som oppgis av tilpasningsindekser. Men uavhengig av dette gir våre funn støtte til at bruk av skalaen basert på parsellering synes fruktbar ved studier av treneres mestringstro. Vi fant også at tilpasningen av modellen til data var invariant over tid. Det betyr at skalaen også er egnet ved måling av endringer i mestringstro blant trenere over tid. Invarians testet mellom grupper (dvs. intervensjons og kontrollgruppe) ble imidlertid ikke oppnådd. Det betyr at skalaen i vårt tilfelle ikke kan brukes til å undersøke eventuelle effekter av tiltak hvor man prøver å påvirke treneres mestringstro. 
Analysene støtter samlet opp under uttalte fordeler ved bruk av parselleringsteknikk, ved at denne skaper mer robuste forutsetninger ved tilpasning av en målemodell til data. Little (2013) peker i den forbindelse på følgende: «Parceling reduces both the sampling variability of the selected sample and the amount of incorrectness of my model in the population. The benefits of reducing the likelihood of correlated residuals and dualfactor loadings are both aspects of how parcels reduce sampling variability or population misfit» (s. 24-25). Vi vil anbefale at andre som måtte ta i bruk skalaen i en eventuelt framtidig undersøkelse, sørger for å sjekke mønsteret i faktorladningene med tanke på balansert oppsett av parseller, da mønsteret i faktorladningene rimeligvis vil endre seg i studier basert på andre utvalg (Kline, 2011).

I tråd med anbefalinger (Byrne, 2012) undersøkte vi også konvergerende og diskriminerende validitet på de fire mestringstrodimensjonene. Estimatene var gjennomgående gode, og bedre enn hva som er funnet tidligere innenfor tilsvarende trenerutvalg (Feltz et al., 2009). Et klart unntak var manglende diskriminerende validitet mellom mestringstrodimensjonene: Motivasjon og Karakterbygging $(r=.90)$. Feltz et al. (2009) har argumentert for at man ikke nødvendigvis vil finne at ulike aspekter ved dimensjonsvaliditeten i en skala for trenere i barne- og ungdomsidrett evner å skille like klart som blant trenere i mer elitepreget voksenidrett. Det er mulig at det å motivere til å bygge laget blant spillerne veves inn i det å bygge karakter og lagånd i moralsk forstand. Dermed vil trenerne lettere kunne komme til å anse motivering til å opptre på en respektfull måte overfor andre lags spillere og det å motivere til å bygge laget som to sider av samme sak.

Diskriminerende validitet var også marginal (.76) mellom mestringstrodimensjonene Kampstrategi og Teknikk. Én grunn til dette kan være at opplæringskulturen i norsk barne- og ungdomsfotball i stor grad vektlegger treningsformer knyttet til ulike varianter av spill, hvor teknikk og taktikk flyter over i hverandre i trenernes veiledning.

Med hensyn til kriterievaliditet tilknyttet treneres mestringstro, har to tidligere studier undersøkt dette innenfor rammen av barne- og ungdomsidrett. Feltz et al. (2009) og Sullivan et al. (2012) undersøkte mestringsdimensjonene i relasjon til spiller- og trenererfaring, samt lederskapserfaring. Man fant at disse gav støtte til kriterievaliditeten i 
studien. Slike funn kan man dra paralleller til i vår studie, hvor vi finner at en høy skår for mestringstro er positivt forbundet med positive følelsestilstander i trenerrollen. Vitalitetsnivå i dagliglivet forkludrer i marginal grad disse funnene og underbygger at slike sammenhenger ikke er spuriøse. Funnene er i tråd med Banduras sosial-kognitive teori (Bandura, 1997) og empiriske funn (Hu, Motl, McAuley, \& Konopack, 2007) som viser at mestringstro utløser glede og andre positive følelsestilstander under utøvelse av idrett. Man finner tilsvarende sammenhenger innen konteksten skole, hvor mestringstro i rollen som lærer (motivere elever, samarbeide med kolleger, håndtere utfordringer osv.) er relatert til tilfredshet i lærergjerningen (Skaalvik \& Skaalvik, 2010). Vi analyserte også forholdet mellom mestringstro og nivå av formell trenerutdanning, og dette viste at trenere med middels eller høyt nivå av trenerutdanning skåret høyere på mestringstrodimensjonen Teknikk enn de med lite formell utdanning. Resultatet er i tråd med funn blant trenere i Singapore, som viste paralleller blant henholdsvis sertifiserte og ikke-sertifiserte trenere (Lee, Malete, \& Feltz, 2002). Erfaring og kompetanse er gjerne sammenvevd, og Kavussanu og medarbeidere (Kavussanu et al., 2008) fant at antall år med erfaring som trener predikerte mestringstro med henblikk på å utvikle tekniske ferdigheter. Ut fra premisset om at trenere med mer erfaring og formell kompetanse påtar seg mer ansvar, viser jo også våre analyser at mestringstroen gjennomgående er høyere blant trenere som tar hovedansvar for laget, eller som deler dette med en annen person.

\section{Styrker og begrensninger}

Styrker ved denne studien inkluderer grundig analyse av dimensjonsvaliditet, diskriminerende validitet, konvergerende validitet samt kriterievaliditet ved hjelp av flere psykometriske indikatorer. Analyse av invarians over tid bidrar dessuten med kunnskap om muligheten for å ta i bruk instrumentet i måling av endringer over tid i treneres mestringstro (Byrne, 2012). Denne studien legger til grunn bruk av samme utvalg ved ESEM-analyse, innledende CFA-analyse og påfølgende bruk av parsellering. Det vil kunne være innsigelser mot en slik tilnærming, 
da studier ved bruk av CFA ofte gjør bruk av et utvalg i ESEM-fasen, for så å bruke et nytt utvalg i CFA-fasen. Dette var det ikke mulighet til i vårt tilfelle, og det kan ses som en begrensning ved studien. For øvrig ble to utsagn fra den opprinnelige 24-utsagnsskalaen tatt bort (Feltz et al., 1999, 2009). Dette gjorde vi ved hjelp av ESEM-analyser i en eksplorativ fase, mens vi ikke foretok ytterligere «inngrep» i skalaen i den bekreftende fasen (CFA). Vi mener dermed at vi har et akseptabelt grunnlag for bruk av parsellering som endelig analysestrategi. For øvrig har vi empirisk og teoretisk søkt å grunngi at de to utsagnene (a) finne ut av motstanderlagets sterke sider $i$ kamp, og (b) forberede spillerne mentalt på kamp, ble tatt ut i ESEM-analysen.

Feltz og medarbeidere (Feltz et al., 2009) anvendte en responsskala med fem kategorier basert på anbefalinger fra Myers og medarbeidere (Myers, Wolfe, \& Feltz, 2005). Disse observerte at bare en prosent av trenerne tok i bruk de laveste responskategoriene mellom o og 4. Gjennomsnittsverdier over de 22 utsagnene i vårt materiale lå mellom 6.7 og 7.8, og kun rundt $3 \%$ av trenerne tok i bruk responskategoriene mellom o og 4. Dette kan tyde på at man i nye studier med skalaen bør kunne ta i bruk en responsskala med syv kategorier (Zimet, Dahlem, Zimet, \& Farley, 1988).

\section{Konklusjon}

Studien viser at en 22-utsagnsbasert, firedimensjonal målemodell av treneres mestringstro i rollen som trener i breddefotballen gir god tilpasning til data. Parselleringstilnærmingen gav betydelig støtte til god dimensjonsvaliditet for de fire parsellbaserte dimensjonene. Invarians over tid ble bekreftet for intervensjons- og kontrollgruppen samlet. Invarians mellom intervensjons- og kontrollgruppe over tid ble ikke oppnådd. Vi observerte god konvergerende og diskriminerende validitet. Kriterievaliditet ble også bekreftet. I sum synes skalaen å være velegnet til undersøkelse av tverrsnitts- og lengdesnittstudier av mestringstro som trener i barne- og ungdomsidrett. Framtidige studier må bekrefte invarians mellom undergrupper i et materiale. Dette kan for eksempel være grupper som har fått, eventuelt ikke fått et tiltak, før disse sammenliknes på relevante utfallsvariabler. 


\section{Referanser}

Anderson, J.C. \& Gerbing, D.W. (1988). Structural equation modeling in practice: A review and recommended two-step approach. Psychological Bulletin, 103, 411-423.

Bandura, A. (1997). Self-efficacy: The exercise of control. New York: Freeman.

Bagozzi, R.P. \& Edwards, J.R. (1998). A general approach for representing constructs in organizational research. Organizational Research Methods,1, 45-87.

Benight, C.C. \& Bandura, A. (2004). Social cognitive theory of posttraumatic recovery: the role of perceived self-efficacy. Behaviour Research and Therapy, 42, 1129-1148.

Bentler, P.M. (1990). Comparative fit indexes in structural models. Psychological Bulletin, 107, 238-246.

Bentler, P.M. (1995). EQS structural equations programs manual. Encino, CA: Multivariate Software, Inc.

Browne, M.W. \& Cudeck, R. (1993). Alternative ways of assessing model fit. I: K.A. Bollen \& J.S. Long (red.), Testing structural equation models (s. 136-162). Thousand Oaks, CA: Sage.

Byrne, B.M. (2012). Structural equation modeling with Mplus. Basic concepts, applications, and programming. NY: Routledge.

Campbell, T. \& Sullivan, P.J. (2005). The effect of a standardized coaching education program on the efficacy of novice coaches. Avante, 11, 38-45.

Cheung, G.W. \& Rensvold, R.B. (2002). Evaluating goodness-of-fit indexes for testing measurement invariance. Structural Equation Modeling, 9, 233-255.

Chen, F.F. (2007). Sensitivity of Goodness of Fit Indexes to Lack of Measurement Invariance. Structural Equation Modeling: A Multidisciplinary Journal, 14, 464-504.

Cole, D.A. (1987). Utility of confirmatory factor analysis in test validation research. Consulting and Clinical Psychology, 55, 584-594.

Dimitrov, D.M. (2010). Testing for factorial invariance in the context of construct validation. Measurement and Evaluation in Counseling and Development, 43, 121-149.

Dong, Y. \& Peng, C.-Y.J. (2013). Principled missing data methods for researchers. SpringerPlus, 2, 1-17.

Duda, J.L. \& Nicholls, J.G. (1992). Dimensions of achievement motivation in schoolwork and sport. Journal of Educational Psychology, 84, 290-299.

Epstein, J., Santo, R.M., \& Guillemin, F. (2015). A review of guidelines for crosscultural adaptation of questionnaires could not bring out consensus. Journal of Clinical Epidemiology, 68, 435-441. 
Feltz, D.L., Chase, M.A., Moritz, S.E., \& Sullivan, P.J. (1999). Development of the multi-dimensional coaching efficacy scale. Journal of Educational Psychology, 91, 765-776.

Feltz, D.L., Short, S.E., \& Sullivan, P.J. (2008). Self-efficacy in sport. Champaign, IL: Human Kinetics.

Feltz, D.L., Hepler, T.J., Roman, N., \& Paiement, C.A. (2009). Coaching efficacy and youthsport coaches. The Sport Psychologist, 23, 24-41.

Fornell, C., Larker, D.F. (1981). Evaluating structural equation models with unobservable variables and measurement error. Journal of Marketing Research 18 , 39-50.

Geiser, C. (2013). Data analysis with Mplus. New York, The Guilford Press.

Hollembeak, J. \& Amorose, A.J. (2005). Perceived coaching behaviors and college athletes' intrinsic motivation: A test of self-determination theory. Journal of Applied Sport Psychology, 17, 20-36.

Horn, T.S. (2002). Coaching effectiveness in the sport domain. I T.S. Horn (red.), Advances sport psychology (s. 309-354). Champaign, IL: Human Kinetics.

Hu, L. \& Bentler, P.M. (1999). Cutoff criteria for fit indexes in covariance structure analysis: Conventional criteria versus new alternatives. Structural Equation Modeling, 6, 1-55.

Hu, L., Motl, R.W., McAuley, E., \& Konopack, J.F. (2007). Effects of self-efficacy on physical activity enjoyment in college-aged women. International Journal of Behavioural Medicine, 14, 92-96.

Jerome, G.J., Marquez, D.X., McAuley, E., Canaclisova, S., Snook, E., \& Vickers, M. (2002). Self-efficacy effects on feeling states in women. International Journal of Behavioral Medicine, 9, 139-154.

Jourden, F.J., Bandura, A., \& Banfield, J.T. (1991). The impact of conceptions of ability on self-regulatory factors and motor skill acquisition. Journal of Sport \& Exercise Psychology, 8, 213-226.

Kavussanu, M., Boardley, I.D., Jutkiewicz, N., Vincent, S., \& Ring, C. (2008). Coaching efficacy and coaching effectiveness: examining their predictors and comparing coaches' and athletes' reports. The Sport Psychologist, 22, 383-404.

Kline, R.B. (2011). Principles and practice of structural equation modeling. NY: The Guilford Press.

Lee, K.S., Malete, L., \& Feltz, D.L. (2002).The strength of coaching efficacy between certified and noncertified Singapore coaches. International Journal of Applied Sport Sciences, 14, 55-67.

Little, T.D. (2013). Longitudinal structural equation modeling. New York, NY: Guilford Press. 
Little, T.D., Jorgensen, T.D., Lang, K.M., Whitney G., \& Moore, E. (2014). On the joys of missing data. Journal of Pediatric Psychology, 39, 151-162.

Little, T.D., Rhemtulla, M., Gibson, K., \& Schoemann, A.M. (2013). Why the item versus parcels controversy needn't be one. Psychological Methods, 18, 285-300.

Malete, L. \& Feltz, D. (2000). The effect of a coaching education program on coaching efficacy. The Sport psychologist, 14, 410-417.

Malete, L., Chow, G.M., \& Feltz, D. (2013). Influence of coaching efficacy and coaching competency on athlete-level moral variables in Botswana youth soccer. Journal of Applied Social Psychology, 43, 2107-2119.

Mageau, G.A., \& Vallerand, R.J. (2003). The coach-athlete relationship: A motivational model. Journal of Sport Sciences, 21, 883-904.

McAuley, E., Talbot, H.M., \& Martinez, S. (1999). Manipulating self-efficacy in the exercise environment in women: Influences on affective responses. Health Psychology, 18, 288-294.

Marsh, H.W., Wen, Z., \& Hau, K.-T. (2004). Structural equation models of latent interactions: Evaluation of alternative estimation strategies and indicator construction. Psychological Methods, 9, 275-300.

Myers, N.D., Feltz, D.L., \& Wolfe, E.W. (2008). A confirmatory study of rating scale category effectiveness for the coaching efficacy scale. Research Quarterly for Exercise and Sport, 79, 300-311.

Myers, N.D., Chase, M.A., Pierce, S.W., \& Martin, E. (2011). Coaching efficacy and exploratory structural equation modeling: a substantive-methodological synergy. Journal of Sport \& Exercise Psychology, 33, 779-806.

Pelletier, L.G., Fortier, M.S., Vallerand, R.J., \& Briere, N.M. (2001). Associations among perceived autonomy support, forms of self-regulation, and persistence: A prospective study. Motivation and Emotion, 25, 279-306.

Quested, E., Ntoumanis, N., Viladrich, C., Haug, E., Ommundsen, Y., Van Hoye, A., \& Duda, J.L. (2013). Intentions to drop-out of youth soccer: a test of the basic needs theory among European youth from five countries. International Journal of Sport and Exercise Psychology, 11, 395-407.

Ryan, R.M. \& Frederick, C.M. (1997). On energy, personality and health: Subjective vitality as a dynamic reflection of well-being. Journal of Personality, 65, 529-565.

Satorra, A. \& Bentler, P.M. (2001). A scaled difference chi-square test statistic for moment structure analysis. Psychometrica, 66, 507-512.

Segal, M.H., Lonner, W.J., \& Berry, J.W. (1998). Cross-cultural psychology as a scholarly discipline. American Psychologist, 53, 1101-1110.

Skaalvik, E. \& Skaalvik, S. (2010). Teacher self-efficacy and teacher burnout: A study of relations. Teaching and Teacher Education, 26, 1059-1069. 
Solstad, B.E. (2017).Towards a better understanding of the dynamics of sports coaching at the youth level: The coach's perspective. A study of the Youth Football Coaches participation in the Norwegian Arm of the promoting Adolescent Physical Activity (PAPA) project. Oslo: Norges idrettshøgskole. Doktorgradsavhandling.

Solstad, B.E., Van Hoye, A., \& Ommundsen, Y. (2015). Social-contextual and intrapersonal antecedents of coaches' basic need satisfaction: The intervening variable effect of providing autonomy-supportive coaching. Psychology of Sport and Exercise, 20, 84-93.

Su, C.T. \& Parham, L.D. (2002). Case report: Generating a valid questionnaire translation for cross-cultural use. American Journal of Occupational Therapy, 56, 581-585.

Sullivan, P. \& Kent, A. (2003). Coaching efficacy as a predictor of leadership style in intercollegiate athletics. Journal of Applied Sport Psychology,15, 1-11.

Sullivan, P., Paquette, K.J., Holt, N.L., \& Bloom, G.A. (2012). The relation of coaching context and coach education to coaching efficacy and perceived leadership behaviors in youth sport. The Sport Psychologist, 26, 122-134.

Watson, D., Clark, L.A., \& Tellegen, A. (1988). Development and validation of brief measures of positive and negative affect: The PANAS scales. Journal of Personality and Social Psychology, 54, 1063-1070.

Wiersma, L.D. \& Sherman, C.P. (2005). Volunteer youth sport coaches' perspectives of coaching education/certification and parental codes of conduct. Research Quarterly for Exercise and Sport, 76, 324-338.

Yang, Y. \& Green, S.B. (2010). A note on structural equation modeling estimates of reliability. Structural Equation Modeling: A Multidisciplinary Journal, 17, 66-81.

Zimet, G.D., Dahlem, N.W., Zimet, S.G., \& Farley, G.K. (1988). The multidimensional scale of perceived social support. Journal of Personality Assessment, 52, 30-41. 
Vedlegg. Treneres mestringsforventning, norsk versjon.

\section{Hvor stor tro har du på at du kan:}

1. (M) bidra til at spillere bevarer troen på seg selv

2. (KS\#) finne ut av motstanderlagets sterke sider i kamp

3. (M\#) forberede spillerne mentalt på kamp

4. (KS) anvende ulik taktikk i kamp

5. (K) oppmuntre til gode moralske holdninger

6. (M) bygge et positivt selvbilde hos spillerne

7. ( $T$ ) demonstrere ferdigheter/øvelser innen fotball

8. (KS) endre eget spill / egen taktikk slik at det/den tilpasses ulike kampsituasjoner

9. (KS) finne ut av motstanderes svakheter i kampsituasjoner

10. (M) motivere spillerne

11. (KS) ta viktige avgjørelser under kamp

12. (M) utvikle/bygge samhold i laget

13. (K) fremme en fair play-holdning hos spillerne

14. ( $T$ ) veilede spillerne når det gjelder teknikk/ ferdigheter

15. (M) utvikle spillernes tro på seg selv

16. ( $T$ ) utvikle spillernes talent

17. (KS) fremme spillernes/lagets sterke sider under kamp

18. ( $\mathrm{T}$ ) identifisere spillernes talent

19. (K) fremme god sportsånd

20. (T) oppdage tekniske/ferdighetsmessige feil

21. (KS) tilpasse kampstrategier med utgangspunkt i lagets ferdighetsnivå

22. ( $T$ ) lære bort ferdigheter i fotball

23. (M) bygge lagets tro på seg selv

24. (K) fremme en holdning om å respektere hverandre

Note. \#utsagn 2 og 3 ble tatt ut grunnet høy residual varians.

$\mathrm{M}=$ Motivasjon; $\mathrm{KS}=$ Kampstrategi, $\mathrm{T}=$ Teknikk; $\mathrm{K}=$ Karakterbygging. 


\title{
Profesjonelle fotballtreneres interaksjon med sine overordnede og assistenter
}

\section{Bruk av orkestrering og mikropolitisk leseferdighet}

\author{
Jørgen Holmemo \& Frank Eirik Abrahamsen* \\ Norges idrettshøgskole, Seksjon for coaching og psykologi
}

\begin{abstract}
Sammendrag: Forskning på coaching i idrett har lenge vært opptatt av hvordan trenere samhandler med sine spillere. De siste årene har det blitt utført mer idrettspsykologisk forskning på trenerrollen, men treneres samhandling med overordnede og ansatte i klubbene har fått lite oppmerksomhet. Det er grunn til å hevde at måten trenere håndterer denne delen av sitt yrke på, kan ha stor innvirkning på hvor godt de er i stand til å utføre jobben sin. Denne studien går i dybden på hvordan tre erfarne norske elitefotballtrenere (gjennomsnittlig 25 års erfaring på elitenivå) samhandler med andre i klubbene for å skape handlingsrom for seg selv og for å nå sine mål gjennom mikropolitisk virksomhet og orkestrering, som kort fortalt handler om treneres handlinger for å øke sin egen innflytelse og påvirkningsmulighet i organisasjonen. Vi samlet data gjennom semi-strukturerte intervjuer. Deretter brukte vi innholdsanalyse basert på et teoretisk rammeverk bestående av orkestreringsmetaforen og studier på mikropolitikk og de tre aspektene av mikropolitiske ferdigheter. Resultatene og diskusjonen beskriver hvordan trenerne håndterer forhandlingsprosessen før de blir ansatt av en klubb, hvordan de håndterer overordnede og ansatte, og hvordan de har utviklet sin mikropolitiske kompetanse gjennom karrieren. Trenernes kunnskap og oppmerksomhet om disse prosessene var integrerte deler av deres coaching- og ledelsesutfordringer. Kunnskap om orkestrering og mikropolitikk syntes å være viktig for dem i den nåværende studien. Vi gir derfor noen forslag til hvordan trenere kan forbedre sin evne til å håndtere disse elementene i trenerutdanningen, og foreslår mulig fremtidig forskning og anvendte implikasjoner for trenere.
\end{abstract}

Nøkkelord: coaching, orkestrering, mikropolitikk, mikropolitisk kompetanse

\begin{abstract}
Research on coaching in sports has long been concerned with how coaches interact with their players. In recent years, more research in sports psychology has been conducted on the coach's role. However, research on coaches' co-operation with leaders and staff in the clubs has received little attention. There is reason to argue that the way coaches handle this part of their profession can have a huge impact on how well they are able to do their job. This study explores how three experienced Norwegian elite football coaches (average 25 years of elite experience) interact with others in their clubs creating room for themselves and achieving
\end{abstract}

\footnotetext{
${ }^{\star}$ Korresponderende forfatter: Frank Abrahamsen, Seksjon for Coaching og Psykologi, Norges idrettshøgskole, 0806 Oslo. E-post: f.e.abrahamsen@nih.no

Sitering av denne artikkelen: Holmemo, J. \& Abrahamsen, F.E. (2018). Profesjonelle fotballtreneres interaksjon med sine overordnede og assistenter: Bruk av orkestrering og mikropolitisk leseferdighet. I T. Haugen \& R. Høigaard (red). Trender i idrettspsykologisk forskning i Skandinavia (Kap. 4, s. 73-102). Oslo: Cappelen Damm Akademisk. DOI: https://doi.org/10.23865/noasp.39.ch4

Lisens CC-BY 4.0
} 
their goals through micro-political activity and orchestration, i.e. coaches' actions to increase their own influence and power within the organization. We collected data through semi-structured interviews. Then we used content analysis based on a theoretical framework consisting of the orchestration metaphor and studies on micropolitics and the three aspects of micropolitical proficiency. The results and discussion describe how the coaches handle the negotiation process before joining a club, how they handle managers and employees, and how they have developed their micropolitical skills through their careers. Their knowledge about and attention to these processes were integral parts of their coaching and leadership challenges. Knowledge of orchestration and micropolitics seemed to be important for the coaches in the current study. We therefore provide some suggestions as to how coaches can improve their ability to handle these elements in coach education and suggest possible future research and applied implications for coaches.

Keywords: coaching, orchestration, micro-policies, micro-political literacy

\section{Introduksjon}

Å være fotballtrener på høyt nivå kan være en svært vanskelig og stressende jobb (Chroni, Abrahamsen, \& Hemmestad, 2016; Knight, Reade, Selzler, \& Rodgers, 2013). Når laget vinner, betraktes treneren ofte som et geni, men når det taper, kan trenerens avgang bli etterspurt. I en resultatbasert virksomhet, slik som profesjonell fotball, vet trenere at selv en kort periode med dårlige resultater kan koste dem jobben. Av de 119 hovedtrenerne som forlot sine stillinger i den norske eliteserien for herrer i perioden 1995-2006, måtte hele 86 gå av ufrivillig (Arnulf, Mathisen, \& Hærem, 2012). Lignende tall finner man på De britiske øyer: Ifølge foreningen The League Managers Association (sesongen 2015/2016) måtte 70 hovedtrenere forlate sine stillinger i de 92 klubbene i de fire øverste divisjonene, og av disse fikk 56 stykker sparken. Det er tydelig at dette ikke er et yrke som gir høy jobbsikkerhet.

Selv om elitetrenere først og fremst bedømmes etter resultater, er ikke det den eneste avgjørende faktoren for om de får beholde jobben sin eller ikke. Et godt forhold til innflytelsesrike personer i klubben er også viktig (Jones, Wells, Peters, \& Johnson, 1993). En treners evne til å påvirke mektige personer i klubben og holde dem på sin side kan ha betydning for hvor stort handlingsrom treneren har, og dermed påvirke hvor godt han eller hun kan utføre jobben (f.eks. Allen \& Shaw, 2013, Cruickshank \& Collins, 2012a, 2012b; Jones et al., 1993; Relvas, Littlewood, Nesti, Gilbourne, \& Richardson, 2010). Mye har blitt skrevet om hvordan trenere bør samhandle med spillerne (f.eks. Jones, 2009; Zourbanos, Haznadar, Papaioannou, 
Tzioumakis, Krommidas, \& Hatzigeorgiadis, 2016), men svært få studier har sett på deres forhold til sine medarbeidere og overordnede.

Den siste tiden har trenere fått mer oppmerksomhet som subjekt - og ikke kun som en faktor for å påvirke utøvere på best mulig måte. Blant annet finnes det en del forskning på trenere og stress (f.eks. Bird, 2003; Capel, Sisley, \& Desertrain, 1987; Wu, 1991), mellommenneskelige forhold med eksempelvis fans og foreldre (Wegge, 2002; Wu, 1991) samt forholdet mellom trener og utøvere (Kroll \& Gundersheim, 1982; Theobald, 1991). Sullivan og Nasham (1993) rapporterte om spillerrekruttering, manglende tid, fravær fra familie og trykk fra media som stresskilder blant olympiske trenere. Nyere studier som er basert på kvalitative data, har gitt oss dypere forståelse for treneres stressopplevelse (f.eks. Chroni et al., 2013; Frey, 2007; Knight et al., 2013; Levy, Nicholls, Marchant, \& Polman, 2009; Olusoga, Butt, Hays, \& Maynard, 2009; Olusoga, Butt, Maynard, \& Hays, 2010; Olusoga, Maynard, Hays, \& Butt, 2012; Thelwell, Weston, Greenlees, \& Hutchings, 2008). Felles for disse studiene er at de identifiserer mange stressorer som kan påvirke jobben trenerne utfører, og noen av disse er: manglende kontroll over hva utøvere presterer, kommunikasjon, uklare forventninger samt forventningspress, organisasjonsutfordringer, lange dager, manglende sosial støtte, administrasjon, konflikter etc. I tillegg har flere studier på trenere (f.eks. McNeill, Durand-Bush, \& Lemyre, 2016), også i Norge og Skandinavia (Bentzen, Lemyre \& Kenttä, 2014, 2016a, 2016b, 2017), undersøkt utbrenthet i sammenheng med yrkesutførelsen.

Til tross for slik forskning vet vi lite om hva trenere faktisk gjør for å «overleve» i yrket, og som Chroni og kolleger (2016) etterlyser, trenger vi mer forskning om hvordan trenere håndterer en krevende jobb over tid. Temaer som det å bygge gode relasjoner og påvirke sentrale personer i en profesjonell klubb synes å være en integrert del av trenerjobben i fotball, og derfor er dette et forskningsområde som fortjener mer oppmerksomhet. Orkestreringsmetaforen (f.eks. Jones \& Wallace, 2005, 2006; Wallace \& Poclington, 2002) og rammen av mikropolitisk kompetanse (f.eks. McCalla \& Fitzpatrick, 2016; Thompson, Potrac, \& Jones, 2015) vil kunne gi et godt ståsted for å studere dette oversette området av elitecoaching. 


\section{Teoretisk rammeverk}

Orkestrering ble opprinnelig utviklet av Wallace og Pocklington (2002) som et konsept for å forstå hvordan skoleledere håndterte kompliserte utdanningsendringer. Modellen presenterer en fleksibel strategi for å takle tvetydigheter og kompleksitet i flere organisasjonssystemer. Det siste tiåret har det vært argumentert at coaching også er en komplisert og tvetydig aktivitet (Jones \& Wallace, 2005, 2006). Trenere har sjelden fullstendig oversikt og kontroll over hva som skjer i klubben, i tillegg til at andre personer kan ha motstridende mål og verdier, og derfor kan ikke coaching sies å være en fullstendig rasjonell aktivitet (Jones \& Wallace, 2005, 2006). Orkestrering foreslås som en strategi for å forstå og håndtere tvetydighet og kompleksitet $\mathrm{i}$ trenergjerningen, og $\mathrm{i}$ coaching blir metaforen definert slik: «Coordinated activity within set parameters expressed by coaches to instigate, plan, organize, monitor and respond to evolving circumstances in order to bring about improvement in the individual and collective performance of those being coached» (Jones \& Wallace, 2005, s. 128).

Kortfattet innebærer orkestrering i idrett at det er grenser for en treners påvirkning i en klubb, og trenere prøver derfor å lede på de områdene hvor de opplever å ha mest innvirkning (Jones \& Wallace, 2005, 2006). Det innebærer styring, bruk av belønninger samt å skape insentivordninger i stedet for å kontrollere og gi ordre for å skape innflytelse. Orkestrering innebærer også å holde øye med hva som foregår i teamet, og prøve å innhente så mye informasjon som mulig for å kunne ta informerte beslutninger (Jones, Bailey, \& Thompson, 2013). Metaforen om orkestrering ble introdusert som en måte å beskrive tvetydigheten og kompleksiteten som er typisk i coaching-prosessen på (Jones \& Wallace, 2005). Jones og Wallace (2005) hevdet at mange modeller og teorier i og for coaching er altfor enkle, og at de gir en uproblematisk og mekanisk representasjon av en svært kompleks virkelighet. En del av grunnen til dette er at vi fortsatt ikke fullt ut forstår alle aspekter av coaching, men vi er ivrige etter å lage skisser for hvordan trenergjerningen skal utføres. Å forsøke å gi løsninger på et problem som vi ikke forstår fullt ut, skaper fort en omstendighet med overforenklede løsninger (Jones \& Wallace, 2005). Kort sagt antas orkestrering å være et mer subtilt og fleksibelt 
alternativ til tradisjonelle ledelsesteorier (for en mer fullstendig beskrivelse av orkestreringsmetaforen og dens innhold, se Jones et al., 2013 eller Jones \& Wallace, 2005, 2006).

Det meste av litteraturen om orkestrering i coaching har fokusert på hvordan trenere samhandler med spillere og, i mindre grad, assisterende trenere. Den siste tiden har trenere fått mer oppmerksomhet som subjekt og ikke kun som en faktor for å påvirke utøvere på best mulig måte. Blant annet finnes det en del forskning på trenere og stress (f.eks. Bird, 2003; Capel, Sisley, \& Desertrain, 1987; Wu, 1991) samt treneres opplevelse av mellommenneskelige forhold til eksempelvis fans og foreldre (Wegge, 2002; Wu, 1991) samt idrettsutøvere (Kroll \& Gundersheim, 1982; Theobald, 1991). Hvordan trenere samhandler med sine overordnede, har derimot $i$ stor grad blitt ignorert. For å forbedre orkestreringsmetaforen burde aspekter som omhandler kompleksiteten ved trenerrollen vies mer oppmerksomhet. Blant annet nevner Nelson, Cushion og Potrac (2013) at litteraturen på trenerutdanning viser at denne utdanningen har hatt liten påvirkning på læringen og utviklingen av trenere. De anbefaler flere pedagogiske tilnærminger for å løse dette problemet, men større grad av erfaringsutveksling blir sett på som nyttig av trenerne, for å gjøre dem bedre forberedt på den faktiske jobben (f.eks. Nelson, Cushion \& Potrac, 2013). Slik kunnskap kan fremskaffes blant annet gjennom å bruke studiet av mikropolitikk under orkestreringsmetaforen, slik det nylig ble foreslått av Jones et al. (2013).

\section{Mikropolitikk og mikropolitisk litteratur}

Studiet av mikropolitikk har fått økende oppmerksomhet innenfor idrettsforskning de siste årene (f.eks. McCalla \& Fitzpatrick, 2016; Thompsonet al et al.., 2015). En mye brukt definisjon av begrepet er som følger: «Micropolitics refers to the use of formal and informal power by individuals and groups to achieve their goals» (Blase, 1991, s. 11). Potrac og Jones (2009b) etterlyste mer forskning på mikropolitikk i coaching ved å peke på hvor krevende trenergjerningen kan være fordi den krever konstant informasjonsinnsamling og vurdering, samt strategisk tenkning for å få andres støtte og tillit. Siden da har flere casestudier beskrevet hvordan trenere engasjerer seg i mikropolitisk aktivitet for å forbedre arbeidsforholdene i 
sine respektive klubber (Potrac \& Jones, 2009a; Potrac, Jones, Gilbourne \& Nelson, 2012; Thompson et al., 2015).

Et kjennetegn ved denne litteraturen er at den, i likhet med mye annen forskning, primært har diskutert trenernes metoder overfor spillerne. De mikropolitiske tiltakene som en trener gjør for å påvirke sine overordnede og sine assisterende trenere, har ikke vært grundig undersøkt. Med tanke på alle stressorene som trenere har rapportert i tidligere forskning (f.eks. Chroni et al., 2013; Frey, 2007; Knight et al., 2013; Levy et al., 2009; Olusoga et al., 2009, 2010, 2012; Thelwell et al., 2008), er det naturlig å anta at trenere som har forblitt i dette yrket over tid, også håndterer mikropolitikk på en annen måte enn det uerfarne trenere eller trenere som blir presset ut av yrket, gjør.

I en studie av unge læreres mikropolitiske aktivitet kom Kelchtermans og Ballet (2002b) opp med begrepet «mikropolitisk kompetanse» for å beskrive lærernes evne til å forstå og takle skolens mikropolitiske landskap. Begrepet består av tre forskjellige aspekter: Kunnskapsaspektet refererer til personens evne til å lese og forstå det mikropolitiske landskapet, samt forstå de politiske implikasjonene av både ord og handlinger. Det instrumentelle aspektet består av bredden til personens repertoar av politiske strategier, evnen til å velge riktige strategier til rett tid og til å bruke disse strategiene riktig. Hvis kunnskapsaspektet beskriver en persons evne til å lese det mikropolitiske landskapet, refererer det instrumentelle aspektet til hans eller hennes evne til å skrive seg inn i det (Kelchtermans \& Ballet, 2002a). Til slutt refererer erfaringsaspektet til hva en person føler om sine egne mikropolitiske kompetanser, inkludert tilfredshet med egen mikropolitisk kunnskap og eget repertoar, og eventuelle følelser av skyld, frustrasjon eller glede etter bruk av slike strategier.

Mikropolitisk kompetanse er blitt foreslått som et nyttig rammeverk for å teoretisere den politiske siden av coaching (Potrac \& Jones, 2009b), og er blitt brukt på denne måten $\mathrm{i}$ casestudie av hvordan en trener var involvert $\mathrm{i}$ politisk aktivitet for å påvirke sine spillere og sin assisterende trener (Potrac \& Jones, 2009a). Andre casestudier har vist at en dårlig utviklet mikropolitisk kompetanse kan skape store utfordringer for en trener (Purdy \& Jones, 2011; Purdy, Potrac \& Jones, 2008; Thompson et al., 2013). Personer høyt oppe på rangstigen i en klubb (f.eks. eier eller styreleder) kan uomtvistelig 
påvirke treneres arbeidsforhold (Cruickshank \& Collins, 2012a, 2012b; Relvas et al., 2010), og det er derfor fruktbart å undersøke treneres samspill med sentrale personer i klubben ut ifra et mikropolitisk perspektiv. Ved å undersøke disse temaene tar denne studien sikte på å utvide konseptene for orkestrering og mikropolitisk kompetanse innen coaching, samt få en bedre forståelse av de indre arbeidene til eliteklubber.

\section{Studiens hensikt}

Formålet med denne studien er å undersøke hvordan erfarne trenere på elitenivå samhandler med sine ansatte og overordnede for å skaffe seg gode arbeidsforhold som trenere - for dermed å kunne maksimere sin innflytelse i klubben.

\section{Metode}

\section{Deltakere}

Tre elitetrenere i fotball ble selektert for deltakelse i studien på bakgrunn av sin erfaring. De hadde alle UEFA PRO-lisens og mer enn tjue års erfaring på høyt nivå (gjennomsnitt = 25 år), hovedsakelig som hovedtrener. To av dem hadde også litt erfaring som assisterende trener. De hadde tilbrakt mesteparten av tiden i de to toppnivåene i norsk fotball, mens to av dem også hadde noe trenererfaring fra utlandet. Samlet har de en sjelden bakgrunn som kan gi et innblikk i hvordan topptrenere «overlever» i et resultatorientert miljø.

\section{Prosedyrer}

Etter å ha fătt godkjenning fra NSD startet vi prosessen med å velge ut deltakere til studien. Vi kontaktet nesten tjue høyt anerkjente og erfarne trenere direkte via telefon eller e-post, basert på deres bakgrunn (Berg, 2007). Fem av dem takket ja til å være med i studien, men vi valgte å bruke data fra de tre mest erfarne kandidatene.

Deretter samlet førsteforfatteren dataene gjennom kvalitative semistrukturerte intervjuer. To pilotintervjuer med mindre erfarne trenere ble 
så gjennomført for at vi skulle kunne forberede oss best mulig samt teste og forbedre intervjuguiden (Sparkes \& Smith, 2013). Intervjuguiden inneholdt hovedtemaer med spørsmål samt flere mulige oppfølgingsspørsmål for disse emnene. Hovedtemaene var som følger: håndtering av styret og andre overordnede, arbeidet med de ansatte, implementering av endringer, håndtering av motgang og til slutt hvordan trenere hadde utviklet sin forståelse av disse emnene gjennom hele karrieren.

Til sammen utgjorde de tre intervjuene rundt 200 minutter innspilt lyd. Opptakene ble deretter transkribert til 57 sider med tekst (1,5 mellomrom, Times New Roman, 12 pt). Vi har valgt å rettskrive teksten for leserens skyld, men har kontrollert at essensen av hvert sitat ble opprettholdt i denne prosessen.

\section{Dataanalyse}

Intervjuutskriften ble analysert gjennom deduktiv innholdsanalyse (Elo \& Kyngäs, 2008). Her leser forskeren gjennom hver transkripsjon flere ganger for å få så komplett forståelse av konteksten som mulig. Vi brukte Balls (1987) konseptuelle rammeverk for mikropolitisk analyse som struktur i den første delen av analysen, fordi dette gir en ordnet fremstilling av hvordan informanten opplever det mikropolitiske landskapet. Dette var en del av forskernes arbeid med å få full oversikt og forståelse av materialet.

Vi fulgte deretter retningslinjene som blant annet Hsieh og Shannon (2005) anbefaler for analyseprosessen. Kodekategorier ble forhåndsbestemt ut fra teoretisk rammeverk om orkestrering og mikropolitisk kompetanse. Induktive koder ble benyttet for å fange emner som ble tatt opp av informantene dersom svarene ikke passet inn i noen av de forhåndsbestemte kategoriene. Deretter gjorde vi en dybdeanalyse av hvert intervju, før vi så på alle intervjuene samlet for å søke etter mønstre og fellestrekk i deltakernes erfaringer og opplevelser.

\section{Resultater og diskusjon}

Resultatene har, som nevnt tidligere, blitt analysert med bakgrunn i teorigrunnlaget og i diskusjon mellom forfatterne og tredjepersoner som har 
gitt gode innspill. På bakgrunn av mønstre og fellestrekk som ble funnet i intervjudataene gjennom dette arbeidet, har presentasjonen av dataene blitt delt inn i fem kategorier, rettet mot fem forskjellige aspekter av trenernes erfaringer: (1) forhandlingsprosessen før de ansettes av klubben; (2) håndtering av overordnede og andre mektige personer i klubben; (3) arbeidet med egne assistenter og ansatte; (4) hva som skjer når laget spiller dårlig; og (5) hvordan de har utviklet sin forståelse av det mikropolitiske landskapet i fotballklubber gjennom hele karrieren. På de neste sidene diskuterer vi funnene i hver kategori på bakgrunn av de teoretiske rammene.

\section{Tiden før ansettelse}

Det første møtet mellom en trener og en fotballklubb skjer før treneren blir ansatt. Unntaket er når treneren blir forfremmet fra en annen stilling i samme klubb. I den forstand representerer forhandlingsprosessen trenerens første reelle mulighet for politisk aktivitet. Alle de tre trenerne understreket viktigheten av å lytte til klubbens representanter og stille spørsmål under disse samtalene. Deres mål var alltid å finne ut så mye som mulig om klubbens behov og forventninger, og om klubbens nåværende situasjon med tanke på økonomi, organisasjon og støttepersonell. Det var en klar konsensus om at jo mer informasjon de kunne få av klubben under de første forhandlingene, jo bedre var det:

Jeg tenker jo at det viktigste i en sånn innledende prosess er å lytte mest mulig, og prove å danne seg et bilde av hva de er ute etter. Og man bør jo absolutt spørre om «hvorfor er dere interessert i meg?» (trener 2).

Jeg forankrer alltid min filosofi til dem som spør etter mine tjenester. Da vet jeg at jeg fär en trygghet for at de aksepterer måten min å jobbe på og hva jeg vil forsøke å få til med laget og enkeltspillere. (...) Og da er det liksom åpent for å stille spørsmål rundt det, og da får vi ofte en diskusjon om hvordan vi kan gjennomføre $\operatorname{det}$ (trener 3).

Ved å engasjere seg i grundige diskusjoner før de signerte en kontrakt, trodde trenerne at potensielle problemer kunne unngås før de oppsto. Alle trenerne hadde opplevd vanskeligheter mellom dem selv og sentrale 
personer i klubben, slik som styre/styreleder, daglig leder, supportleder og sponsorer. Det kunne være forskjellige meninger om sportslige målsettinger og ambisjoner, sportslig vurdering om treningsopplegg og spillestil samt uenighet om hvordan klubbenes økonomiske ressurser skulle forvaltes. Ved å ta opp slike bekymringer på et tidlig stadium trodde trenerne at de kunne redusere risikoen for at ulikhetene ville forårsake problemer i fremtiden.

Dette er ikke nødvendigvis alltid like lett. En av trenerne beskrev hvordan han hadde blitt forledet av en klubbs representanter til å tro at klubben hadde langt bedre økonomi enn den i virkeligheten hadde. Han understreket betydningen av å «stille de riktige spørsmålene» under innledende forhandlinger for å unngå situasjoner som dette. Evnen til å stille gode og kritiske spørsmål under diskusjoner med klubbens ledelse bør betraktes som en del av en treners mikropolitiske kompetanse.

Et tilbakevendende tema blant alle trenerne var villigheten til å være fleksibel. De hevdet alle å tilpasse sin filosofi og sine mål for å passe inn i klubben. Trenere uttrykte imidlertid en klar bevissthet om at det fantes en grense for deres fleksibilitet. De ville ikke godta en jobb hvis de følte at det var for stort gap mellom det de ønsket å oppnå og hva klubben forventet av dem.

Jeg tror man må avklare i detalj hvor mye vi skal trene og hvordan vi skal spille. Slik at klubben kan si «åh, vil du trene så mye? Det passer sannsynligvis ikke vår gruppe». (...) Og når du da kommer i møte med en klubb som sier at «nei, vi vil hvile veldig mye, for vi har veldig trua på at vi skal vere fresh til kampene», så må jeg bare si nei. For da er det veldig sannsynlig at den gruppa her kommer til å hate meg før vi kommer til seriestart (trener 2).

Da trener 2 oppdaget at han og spillerne hadde diametralt motsatte meninger om hvor mye laget skulle trene, innså han at konflikter ville være uunngåelig - og besluttet å ikke ta jobben hos klubben. Ifølge denne treneren var hans villighet til å avslå et jobbtilbud mye større nå enn det var tidligere i karrieren, delvis fordi han var bedre i stand til å se potensielle problemer før de oppsto, slik eksempelet over viser. Dette synspunktet markerte at kunnskapsaspektet i hans mikropolitiske kompetanse hadde forbedret seg gjennom mange års erfaring. 
De tre trenerne var enige om en annen positiv effekt av å gjøre en god jobb under forhandlingsprosessen. Når de signerte en kontrakt etter å ha gjennomgått lange og detaljerte diskusjoner med klubbens representanter, følte trenerne alltid at klubben aksepterte deres måte å jobbe på. I tidlige arbeid med orkestrering understreket Wallace (2003) betydningen av å skape en akseptkultur blant interessenter i en organisasjon for å sørge for at det ikke oppsto misnøye og konflikt på bakgrunn av avgjørelser som ble tatt. Selv om det ikke finnes noen åpenbar, rask og enkel måte å oppnå dette på, trodde trenerne at å engasjere seg i en konstruktiv samtale med klubben før de tok en jobb, var en god start for å bygge en slik akseptkultur:

Jeg har alltid trodd at $i$ det øyeblikket du signerer, er du førstevalget. Det spiller ingen rolle hvor mange mennesker de har avvist før de kommer til deg. I det sekundet du signerer kontrakten, var du den beste personen som klubben kunne få tak i akkurat da (trener 2).

Og så føler jeg at klubben har akseptert filosofien min om hvordan jeg vil bruke støtteapparatet, hvordan jeg vil jobbe med spillerne, hvordan jeg vil implementere filosofien min i klubben (trener 3).

\section{Håndtering av overordnede}

Den neste delen av analysen ser på hvordan trenerne samhandler med sine overordnede for å skape og forsvare sine foretrukne arbeidsmetoder, og for å maksimere sitt eget innflytelsesnivå i klubben. I denne sammenheng omfatter begrepet «overordnede» styret, eierne eller de store aksjonærene, sportsdirektøren og andre som står over treneren i organisasjonshierarkiet.

De tre trenerne nevnte alle at ulike mål hos de overordnede var en stor kilde til tvetydighet i profesjonelle fotballklubber. For eksempel rapporterte de at styremedlemmene ofte har svært forskjellige ambisjoner for hva klubben skal oppnå eller gjøre. Noen personer bryr seg bare om økonomi og profitt, noen ønsker å beskytte klubbens tradisjoner, noen vil at klubben skal vinne Champions League, mens andre bare vil at klubben skal gi et godt sosialt miljø for sine barn: 
Mange av styremedlemmene var foreldre som hadde barna sine $i$ ungdomslaget. De ønsket alltid å prioritere sine barns utvikling (trener 1).

I styret sitter mer den økonomiske kompetansen, og de måler vel mer resultater ut ifra økonomi enn ut ifra kvalifikasjoner i forhold til det å ha tro på folk over lengre tid, selv om resultatene går imot. Så der er jo den blandingen mellom forening og forretning, den er jo veldig komplisert der. Og da får man jo også mange forskjellige meninger, og det fører ofte til forvirring og til strid, og ofte til oppløsning av kontrakter (trener 3).

Slike ulike målsettinger blant sentrale personer i klubben gjør det vanskelig å tilfredsstille alle. De tre trenerne var enige om at det er viktig å identifisere personene som har mest makt i klubben, og deretter prøve å bygge gode relasjoner med dem. Under videre diskusjon av dette emnet hevdet de alle at makten vanligvis er der pengene er. Dette betyr at de mektigste menneskene er de som bidrar mest til klubbenes økonomi vanligvis eieren, store investorer eller store sponsorer. I noen tilfeller kan det også være andre mennesker som er høyt respekterte, og som av en eller annen grunn synes å ha stor innflytelse over folk i klubben:

I en klubb kan du jo ha både formelle og uformelle ledere. Spesielt kan du ha uformelle ledere med mye penger. Og jeg tror at som trener må du finne ut hvor den reelle makten sitter. Så som trener, for å se litt sånn kynisk på det, så må du finne ut hvor den reelle makten sitter, og så må du sørge for å ha kort vei dit og veldig åpen kanal, og bygge relasjoner der (trener 2).

Dette sitatet oppsummerer de tre trenernes tanker om å påvirke overordnede. De var alle enige om at å ha gode relasjoner og tydelig kommunikasjon med de mektigste folkene i klubben var viktig for å øke sin egen innflytelse. Som sitatet antyder, kan det være nødvendig å omgå de offisielle kanalene og kommunisere direkte med personer med den reelle påvirkningskraften, enten det er en ekstern investor eller eieren av klubben. Dette er et eksempel på at trenerne bevisst engasjerer seg i politisk aktivitet for å forbedre arbeidsforholdene sine. Å kunne identifisere de mest innflytelsesrike menneskene i klubben, og deretter bygge gode relasjoner med dem, ser ut til å være en viktig del av en treners mikropolitiske kompetanse, både som en ferdighet og som et instrument for god resultatoppnåelse. 
Til slutt antydet alle informantene at en treners grad av respekt og handlefrihet er avhengig av deres rykte og erfaring. De tre trenerne følte alle at de fikk langt mer ansvar og tillit nå enn tidligere i karrieren:

Da jeg kom til klubben, med alle mine referanser og alt jeg hadde gjort før, hadde jeg automatisk ganske stor gjennomslagskraft. Jeg tror den forrige treneren denne klubben var hans første jobb på toppnivå - han hadde sikkert mange av de samme ideene, men han hadde vanskelig for å få det gjennom. Det har jeg merket selv, fra det å voere fersk topptrener til det å ha fått noen år under beltet. Du får større respekt og det er lettere å få til ting da (trener 1$)$.

Dette indikerer at trenernes tidligere prestasjoner og rykte kan påvirke hvordan folk i klubben behandler dem. Når folk vet hvilken respekt og hvilke meritter trenerne har oppnådd i andre klubber, endres deres oppfatning av dem på en positiv måte. Unge trenere må være oppmerksomme på dette, fordi de må bevise for sine overordnede at de er kompetente og kvalifiserte - til tross for deres begrensede erfaring for å oppnå samme mengde respekt og makt som en mer erfaren trener ville ha fått.

\section{Håndtering av medarbeiderne}

Dette kapittelet tar for seg hvordan trenerne samhandler med andre personer i klubben som ikke er deres overordnede. Det inkluderer assistenttrener, det medisinske personalet, utstyrsforvaltere og enkelte medlemmer av administrasjonen.

Når de snakket om sine viktigste medarbeidere, slik som assistenttreneren, den fysiske treneren og målvaktstreneren, uttalte de tydelig at de alltid foretrekker å ta inn «sine egne folk» når de blir ansatt i en ny klubb. Hvis det er mulig å ta med assistenter som treneren har jobbet med før og ser på som pålitelige, er det deres foretrukne alternativ. På grunn av økonomiske begrensninger er det imidlertid sjelden de får lov til å gjøre dette. I mange tilfeller har trenerne blitt tvunget til å jobbe med assistenter som allerede var i klubben. De tre trenerne var enige om at når dette skjer, er hovedprioriteten å forsikre seg om at de kan stole på dem:

I Norge kan du ikke forvente at klubben lar deg velge 4 assistenter til å bli med deg. Så det er en av utfordringene du har som leder. Det første jeg gjør da, er å 
sitte ned med den aktuelle assistenten og vore veldig direkte om hvordan jeg vil jobbe (trener 2).

De viktigste støttespillerne her er assistenttreneren og målvaktstreneren. Det er de du jobber noermest med. Assistenttreneren var her før jeg kom hit, han var allerede under kontrakt. Jeg måtte sette meg flere ganger ned med ham og forsikre meg om at jeg kunne stole på ham, at jeg hadde full lojalitet. Men det var ikke noe problem i det hele tatt. (...) Og den lojaliteten er ekstremt viktig. Du kan ikke ha en assisterende trener som går bak ryggen din, og snakker til spillerne som sier at «treneren er en idiot» og slike ting (trener 1).

Ifølge de tre trenerne ender forholdet med assisterende trenere vanligvis opp ganske bra. De har imidlertid alle opplevd vanskeligheter når de skal jobbe med en allerede ansatt assistent. Igjen vektla de verdien av å oppdage slike vanskeligheter på et tidlig stadium, før de utvikler seg til store konflikter. En assisterende trener kan i noen tilfeller også ha ambisjoner om å overta hovedtrenerjobben på et visst tidspunkt. I verste fall kan dette få dem til å jobbe mot hovedtreneren i stedet for å støtte ham/ henne, slik det ble beskrevet i en casestudie om det mikropolitiske arbeidet til en semi-profesjonell fotballklubb (Potrac \& Jones, 2009a). Det å være bevisst på denne muligheten kan sees på som en vesentlig del av trenernes mikropolitiske kompetanse. Når de blir spurt om hvordan de opptrer når de tror at assisterende trener er illojal eller ikke til å stole på, var trenerne samstemte i svarene sine:

Når du kommer til et lag hvor det allerede er en assistenttrener, må du finne ut hvor lojaliteten hans ligger. Vil han voere trofast mot deg og klubben, uansett hva, eller er hans lojalitet fortsatt med den tidligere treneren? Og hva betyr det for meg? Vil han akseptere å ha meg som sin nye sjef? Og det kan til tider voere vanskelig. (...) og så blir det en prosess der du til slutt må løse dem fra kontraktene sine. Og det er alltid en forferdelig ting å måtte takle, og det kan påvirke stemningen i laget, men noen ganger er det bare nødvendig (trener 3).

Noen ganger oppdager $d u$ at en assistent ikke er lojal mot deg. Og i disse situasjonene er jeg veldig kynisk. Da blir du «kjegleflytter» resten av kontraktstiden din. (...) Hvis jeg ikke stoler på folk, vil jeg ikke inkludere dem $i$ arbeidet mitt (trener 2). 
Som disse sitatene indikerer, er det første disse trenerne gjør når de føler at de ikke kan stole på en av sine assisterende trenere, å prøve å få dem fjernet fra stillingen. Hvis dette ikke er mulig, vil de forsøke å marginalisere assistenten ved å involvere ham/henne mindre i beslutningsprosessene og holde ham/henne opptatt med mindre fremtredende oppgaver. Formålet er å redusere assistentens innflytelsesnivå. En av trenerne påpekte at det også er viktig å vurdere hvordan samspillet med en medarbeider kommer til å påvirke det generelle humøret til de ansatte. Hvis hovedtreneren sparker en assisterende trener som er godt likt i klubben, risikerer han å bli upopulær blant de øvrige ansatte. Dette illustrerer hvor vanskelig og kompleks denne siden av trenergjerningen kan være. Å kunne forstå og håndtere slike situasjoner krever stor sosial bevissthet og mikropolitisk kompetanse.

Et annet tema som kom opp under intervjuene, var bemyndigelsen av assistenter. Alle trenerne trodde at det var nødvendig å stole på medarbeiderne gjennom å gi dem ansvar og underbygge autonomien for å holde dem tilfredse. De snakket også om å lytte til de ansatte og la dem ta del i beslutningsprosessene:

Og det handler veldig mye om involvering, $d a$. At du fär alle spillere involvert $i$ deres egen utvikling og lagets utvikling, og at du får staben til å tenke på det også. Samtidig som alle rundt deg får sine arbeidsoppgaver som du overlater til dem. At de tar det ansvaret og viser at de kan håndtere det. Så kan du egentlig bare kontrollere og se om ting blir gjort, og så få rapportering ut fra det (trener 3).

Min filosofi er at tre trenere tenker klokere enn én trener. Jeg tror på å involvere medarbeiderne i beslutninger. Det er viktig for å skape eierskap til prosessen. Du må styre dem i den retningen du vil, men du kan ikke bare gå rundt og ta hver eneste beslutning selv (trener 1).

Ifølge de tre trenerne bidrar denne typen demokratisk ledelsesstil til å holde medarbeiderne fornøyde, og får dem til å føle seg som en del av laget. De gjorde det veldig klart at alle vet hvem sjefen er, men de engasjerer seg ikke i unødvendig detaljstyring eller autoritært lederskap. Demokratisk ledelse synes å være veldig kompatibel med orkestreringsmetaforen, da det innebærer diskret organisering og styring i stedet for at man leder på 
en kontrollerende måte. En tidligere studie viste at erfarne fotballtrenere ga sine assistenter stor frihet som en bevisst sosial strategi for å gi dem større eierskap til treningsprosessen, og dermed sikre seg større lojalitet fra dem (Santos, Jones, \& Mesquita, 2013). Det er sannsynlig at denne typen ledelsesstil kan hjelpe trenerne til å skape en akseptkultur blant medarbeiderne (Wallace, 2003).

Videre snakket trenerne om hva de gjør for å få de ansatte til å trekke i samme retning. Som litteraturen om orkestringsmetaforen sier, handler dette i stor grad om å skape insentiver for den enkelte (Jones \& Wallace, 2005; Wallace, 2003). Alle de tre trenerne snakket om å skape insentiver gjennom å forklare til hver av medarbeiderne at deres arbeidssikkerhet og arbeidsforhold avhenger av førstelagets prestasjoner.

Det handler om å få hele klubben til å bry seg om førstelaget. (...) Hvis førstelaget rykker ned, har vi ikke lenger en jobb. Så det er til alles beste å hjelpe førstelaget. Hjelpe dem med å unngå nedrykk (trener 2).

Førstelaget er klubbens hovedprodukt. Det er hva sponsorene vil støtte, det er grunnen til at fansen kommer for å se på. Så alle i klubben bør tenke «hva kan jeg gjøre for å hjelpe førstelaget?» (trener 1).

Her ser vi at trenerne prøver å formidle til sine underordnede at det er $\mathrm{i}$ alles interesse at førstelaget presterer bra, fordi lagets resultater er det viktigste i klubben og har betydning for alles arbeidsforhold. Dette er i stor grad i tråd med filosofien om å bruke belønninger og incitamenter for å påvirke folks handlinger, noe som er sentralt i orkestreringsmetaforen. I et miljø som er fullt av motstridende interesser, kan det å skape insentiver for mennesker være en effektiv måte å styre deres handlinger i ønsket retning på.

Også her understreket alle trenerne igjen betydningen av god kommunikasjon. Å kommunisere tydelig og direkte med de ansatte og sørge for at de forstår hva som blir sagt, synes å være kritisk. Ifølge trenerne oppstår konflikter ofte på grunn av dårlig kommunikasjon:

Du må ha et lag som ønsker å trekke i samme retning. Og man må også kommunisere på samme måte. Svort ofte er en klubbs største problem kommunikasjonen. 
Spillerne hører forskjellige ting fra forskjellige mennesker, noe som fører til forvirring, og til slutt bryter det ned tilliten (trener 3 ).

\section{Dårlige resultater}

Denne delen handler om hva som skjer når førstelaget spiller verre enn forventet over lengre tid, og om hvordan dårlig resultatoppnåelse kan påvirke de ansatte i klubben - slik trenerne opplever det. Ifølge trenerne som deltok i denne studien, syntes to ting å være vanlige når lagene opplever en langvarig periode med dårlige resultater: Det første er at enkelte personer i klubben prøver å distansere seg fra hovedtreneren og førstelaget, og ikke ønsker å være nært forbundet med «fiaskoen»:

Du kan føle det. Folk opptrer svort forskjellig i gode og dårlige tider. Ta for eksempel visse styremedlemmer. I gode tider stopper de og snakker med deg om alt. I dårlige tider holder de avstand. De snakker ikke så mye lenger (trener 1).

Dette kan være en subtil form for politisk aktivitet som folk i klubben engasjerer seg $\mathrm{i}$ - for å kunne distansere seg fra et førstelag som sliter og fra hovedtreneren. I en studie med norske trenere som jobbet under Sochi-OL (2014) og som også har produsert seire over mange år, rapporterte noen av dem at forbundet deres i første omgang prøver å hjelpe landslaget tilbake på vinnersporet før avvikling av jobbforholdet skjer (Chroni et al., 2016). Med andre ord kan ny forskning også se på kulturforskjeller mellom idretter med tanke på det som skjer når resultatene uteblir over tid. Den andre effekten som alle trenerne hadde opplevd under dårlige perioder, var økt involvering av styremedlemmer og andre ledere i klubben. Dette kan sees på som en motsetning fra avstanden enkeltpersoner typisk tar i motgang. Med andre ord opplever treneren at medarbeidere distanserer seg, mens overordnede vil «hjelpe til»:

Det er veldig rart. Du er ansatt fordi administrasjonen tror på din filosofi og på deg som person. Når resultatene er dårlige, foler du at de ikke tror på deg. Og de vil komme opp med mange tiltak som skal hjelpe laget. Og de fleste administratorer og styremedlemmer $i$ et fotballag har ikke peiling på det å lede et fotballag. Og 
plutselig får du alle disse rådene fra folk som aldri har voert på treningsbanen eller trent et lag. Det er veldig rart (trener 3 ).

Ifølge de tre trenerne er økt involvering av overordnede en av de vanligste hendelsene i dårlige perioder. Engasjementet deres kan være velmenende, eller det kan komme fra en mistillit til treneren og hans/hennes metoder. Når de stod overfor tøffe spørsmål fra overordnede i tider med dårlige resultater, understreket alle trenerne viktigheten av å overbevise folk om at du er den rette personen til å snu resultatene. Det å lese miljøet rundt seg er noe som kommer med erfaring og utvikling av mikropolitisk kompetanse. Ifølge trenerne er det viktig å ikke fremstå som overmannet, men heller gi inntrykk av å ha kontroll over og løsninger på det som må gjøres for å snu situasjonen:

Først og fremst, ikke hopp $i$ skyttergraven. Ikke ta det som kritikk og gå rett $i$ defensiv modus. Du må vere rolig, analysere spørsmålet og gi dem et analytisk svar (trener 2).

Noen ganger, hvis laget sliter, vil de hente deg inn for et møte med styret og si «vi sliter, hvordan skal du fikse det?». Og så må du fortelle dem hva planen er. Og du må virke overbevisende. Og når du er ferdig, bestemmer de hva som skjer. «Vi tror på denne fyren, han hadde et selvsikkert kroppsspråk. Han virker ikke påvirket av situasjonen i det hele tatt.» Men hvis du går inn der og det ikke virker som du vet hva du skal gjøre, vil du bli fjernet fra stillingen din. Og da fortjener du å bli fjernet. Jeg vet ikke, men jeg tror det er en del av forskjellen mellom de som sparkes med en gang, og de som får mer tid (trener 1).

Handlingene som trenerne gjennomfører over, ved å uttrykke seg selv som selvsikre og i kontroll, kan på engelsk karakteriseres som «face work» eller «impression management» (Goffman, 1955, 1959).

Ifølge to av trenerne er evnen til å virke trygg i motgang en av faktorene som skiller dem som blir sparket raskt når de møter en periode med dårlige resultater, fra dem som får tid og mulighet til å snu tingene rundt. Betydningen av å handle med selvsikkerhet foran spillere og ansatte har blitt diskutert i tidligere studier (f.eks. Santos et al., 2013), men funnene i den foreliggende studien indikerer at det også er viktig når trenerne håndterer sine overordnede. Å være sikker på sine egne evner samt evnen til 
å holde på tilliten hos de sterke aktørene i klubben, kan i noen tilfeller hjelpe treneren til å kjøpe litt mer tid. Det finnes etter hvert mange studier som også ser på mestringsforventninger (coaching efficacy) hos trenere og virkningen disse har på elementer som lederskap, utdanning og treneres effektivitet (f.eks. Feltz, Chase, Moritz, Sullivan, \& Pressley, 1999; Gearity \& Murray, 2011; Kavussanu, Boardley, Jutkiewicz, Vincent, \& Ring, 2008; Malete \& Feltz, 200o; Sullivan \& Kent, 2003). Trenerne i denne studien lager et poeng av at det er viktig å vise at de tror på det som skal gjennomføres, men fremtidig forskning bør se på sammenhengen mellom reell mestringstro og det som handler om hvordan andre opplever trenerne.

Det er viktig å ha tillit fra styret og andre overhoder, men trenerne var enige om at dette ikke er den eneste faktoren som bestemmer deres skjebne. Ledelsen i en klubb er vanligvis under press fra grupper som supportere, sponsorer og media (Cruickshank \& Collins, 2012a, 2012b). Trenerne trodde at selv når styret mener du er den rette personen for jobben, kan de bestemme seg for å sparke deg ved dårlig resultatoppnåelse for å vise besluttsomhet overfor disse eksterne partene:

La oss si at du er i en av de beste klubbene i Norge. De forventer åpenbart gode resultater. Hvis du sliter, kan ledere i klubben fortsatt tro på deg som trener, men støy fra fansen, innflytelsen fra media - det blir en sånn massesuggesjon. Etter en stund er støynivået så høyt at klubben må ofre deg for å roe alle sammen, og så bare finne en ny trener (trener 1).

Dette funnet indikerer at når laget presterer dårlig, kan trenerens forhold til fansen bidra til om vedkommende forblir ansatt eller ikke. En av trenerne snakket eksplisitt om å bygge opp et godt forhold til supporterne i gode tider - for å sikre noe mer tålmodighet og goodwill til det som ofte er uunngåelige dårlige perioder. Dette ble gjort ved å takke supporterne etter spill, rose dem i medieintervjuer og til og med uttale seg om at «vi har de beste fansene i Europa». Dette kan betraktes som en del av trenerens arsenal av mikropolitiske strategier. Lignende strategier kan også brukes overfor andre eksterne interessenter, som sponsorer og media. Trening i hvordan en skal fremstå i ulike grupper (som media og foran styret ved ansettelser), er en del av utdanningen i dagens UEFA PRO i Norge. Kristiansen, Abrahamsen og Pedersen (2017) anbefaler at trenere utdannes 
og øves i sitt samvirke med blant annet media. For å utøve mikropolitikk på en hensiktsmessig måte anbefales det en bevisst strategi på budskapet en vil fremføre, og dette er - som Kristiansen og kolleger tidvis skriver veldig forskjellig avhengig av hvilken gruppe en kommuniserer med.

Trenerne tenker også at perioder med dårlige resultater kan være mye lettere å håndtere om de har forberedt seg i forkant. Dette inkluderer at de har et velfungerende team av dyktige assistenter som bidrar til å finne ut hva som må gjøres for å forbedre lagets prestasjoner:

Og det er jo der, scerlig, at den sterke gruppa som du prøver å bygge opp, den må jo fungere optimalt når ting butter imot, slik at du slipper å bli isolert. For det er veldig sjelden at du kan komme på noe ultrasmart når ting ikke har fungert før (trener 3).

Men jeg tror at det blir viktig å finne ut hva det er du må holde på, og holde stø kurs, prøve å ikke lytte på alt trøkket som kommer fra forskjellige retninger. Samtidig som du innad, med dine folk, med medisin, med assistentene dine, må snakke mye om hva vi kan gjøre for å få det lille kneppet til høyre som gjør at ting begynner å gå lettere for oss. Så det er håndverk, det er fingerspissfølelse, det er jo det som gjør at du aldri blir utloert, på en måte (trener 2).

Som diskutert tidligere foretrekker trenerne å styrke sine assistenter og til en viss grad utøve en demokratisk lederstil. Dette gir de ansatte autonomi og økt eierskap i lagets prestasjoner, noe som muligens kan gjøre dem bedre egnet til å håndtere de ekstra utfordringene som følger med dårlige resultater (Thompson et al., 2015).

\section{Utvikling av mikropolitisk kompetanse}

Vi har så langt i resultatavsnittet sett hvordan trenerne håndterer forhandlinger i forkant av kontraktsinngåelse og deres tanker om å håndtere overordnede og medarbeidere. Som sitatene har vist, har de klare tanker om den mer politiske delen av yrket sitt, og vi vil i denne delen se hvordan de tre trenerne har utviklet sin mikropolitiske kompetanse gjennom hele karrieren. Det meste av kunnskapen deres om fotballklubbers indre liv er oppnådd gjennom egen erfaring. De hadde alle gått 
gjennom flere trenerkurs og seminarer (både kurs som gir formalkompetanse (eks. UEFA PRO), og mindre formelle kurs som helgekurs m.m.), men den mikropolitiske siden av coaching var knapt blitt diskutert i slike settinger. I løpet av intervjuene ble det også tydelig at de hadde fătt mindre trening i hvordan de skulle orkestrere ulike interessenter under utdanningen. Det er en trend internasjonalt at de «mykere» kommunikasjonsferdighetene vektlegges i trenerutdanningen (f.eks. Gould, Carson, \& Blanton, 2013). Både orkestrering (f.eks. Jones \& Wallace, 2005, 2006; Wallace \& Pocklington, 2002), mikropolitiske ferdigheter (f.eks. McCalla \& Fitzpatrick, 2016; Potrac \& Jones, 2009a; Potrac et al., 2012; Thompson et al., 2013), og kommunikasjon (f.eks. Fletcher \& Hanton, 2003; Kristiansen, Tomten, Hanstad, \& Roberts, 2012; Olusoga, Butt, Hays, \& Maynard, 2009) er egenskaper som kan utvikles både gjennom utdanning og erfaring. Ut fra funnene i denne studien bør disse temaene være en del av trenerutdanningen og ikke fortsette å basere seg kun på at dette er noe trenere erfarer. Som neste sitat viser, ble trenerne i denne studien kastet ut i verden uten å være helt klar for det i starten av karrieren:

Vel ... Noen ganger blir jeg flau når jeg tenker på ting jeg gjorde tidligere, da jeg begynte som trener. Men sånn er livet. Det handler om livserfaring (trener 1 ).

Tidligere casestudier har beskrevet lignende funn, noe som indikerer at mange ferske trenere er uforberedt på maktkampene og konfliktene som kan eksistere i eliteidrett (Potrac et al., 2012; Thompson et al., 2015). I studien til Chroni og kolleger (2016) fortalte informantene om viktigheten av å ha et forbund som heller hjelper dem i arbeidet, og at ulike forventninger fra media og supportere er en del av totaliteten en må håndtere som elitetrener. Om det ikke finnes en klar strategi i miljøet, slik det kunne tyde på at trenerne i Chroni et al. sin studie hadde, blir andre trenere svekket ved å måtte å utvikle sin mikropolitiske kompetanse alene gjennom prøving og feiling uten støtte fra klubb eller forbund. Alle de tre trenerne i denne studien mener at utdanningen kunne forbedres ved å fokusere mer på «skjulte sider» av coaching, slik at unge trenere kan bli bedre til å forstå de uformelle kraftstrukturene i idretten og kommunisere mer effektivt med mennesker i disse settingene: 
Det som trenerutdanningen ville voert styrka på $i$ mitt hode, det er mye mer coaching én til én. Mye mer å forsøke å utvikle treneren til å bli flinkere til å se de uformelle strukturene, flinkere til å kommunisere med folk. For det er jo menneske til menneske, og ikke organisasjonskartet som avgjør om dette blir en suksess eller ikke. Det er jo hvordan du som trener unngår å havne i skyttergropa, unngår å synes synd på deg selv, unngår å synes at verden er urettferdig, unngår å voere ute etter folk som du synes er for dårlige, altså finne måter som du kan leve med virkeligheten som den er, og så påvirke den der du kan påvirke den. Så jeg har mye mer tro på at man kan styrke treneren gjennom å gi ham verktøyene til å kommunisere med folk, eller til å loere seg ting i forhold til «man to man», heller enn å loere seg organisasjonsstrukturer (trener 2).

En annen måte for trenere å utvikle sin mikropolitiske kompetanse på er gjennom trening av kommunikasjon (se f.eks. Kristiansen, Abrahamsen, \& Pedersen, 2017), bruk av veiledning og mentoring. Som tidligere nevnt er dette den internasjonale trenden i moderne trenerutdanning (f.eks. Gould, Carson, \& Blanton, 2013). Som Gould og kolleger skriver, er de «myke» ferdighetene på vei tilbake i trenerutdanningen. Dette går ikke på bekostning av tradisjonelle fag (som fysiologi, anatomi og treningslære), men kommer i tillegg til eksisterende fag. Igjen er kommunikasjon, veiledning og mentoring alle en del av UEFA PRO-utdanningen i Norge, men det kan kanskje være et fag som må prioriteres sterkere tidligere i utdanningen. De tre trenerne i denne studien hadde alle en person som de ofte diskuterte sine problemer med, enten erfarne kolleger eller høyt utdannede «ledere». De trodde alle at diskusjoner med kyndige, kunnskapsrike mennesker kunne bidra til å forbedre dem som trenere. En av trenerne vurderte at mangelen på troverdige og uavhengige diskusjonspartnere potensielt kan være et stort problem for trenere. Han hevdet at du som en trener kan snakke med assistentene dine, men de er ofte partiske og ser på ting fra samme perspektiv som deg, i motsetning til eksterne diskusjonspartnere - som kan utfordre deg med andre synspunkter og se din situasjon fra utsiden.

Et annet funn var at alle de tre trenerne hevdet å ha lært mye om det interne arbeidet $\mathrm{i}$ en klubb med andre trenere under pauser mellom sesjoner på trenerseminarer. Disse «kaffepausene» ga trenerne gode muligheter til å diskutere problemer og lære av hverandre i en uformell setting: 
Jeg har loert mye på trenerseminarer, hvor jeg har loert mest av den sosiale biten, snakket etterpå. Der har vi diskutert hvordan vi holder på, hva vi driver med, hvordan vi prioriterer. Så lytter $d u$, og så tar du med deg ting derfra som andre gjør som de kjenner på er bra, som du kanskje ikke har tenkt på selv. Så den biten der er veldig viktig i utviklinga av deg selv (trener 3 ).

Jeg husker UEFA PRO-lisenskurset mitt. Og det er loererikt - en ting er selve kurset, men det når vi sitter og prater sammen og deler erfaring og opplevelser, så er det utrolig loererikt (trener 1).

Resultatene som presenteres i denne delen, viser at trenerne har utviklet sin mikropolitiske kompetanse først og fremst gjennom egen erfaring og gjennom uformelle læringssituasjoner, nærmere bestemt ved å diskutere med kolleger og andre dyktige personer. Som tidligere nevnt bør dette inngå i trenerutdanningen tidligere enn det gjør nå, kanskje med spesiell vekt på trening, i en bevissthet om hva man skal kommunisere til hvem. I utdanningen til Norges idrettsforbund ligger dette inne i noe av den nyutviklede pensumslitteraturen (f.eks. Abrahamsen \& Gitsø, 2016), der trenere er tenkt å få mer kunnskap i hensiktsmessig kommunikasjon samt i å være mer bevisst rollen sin (f.eks. Wallinus-Rinne, 2016). Studier som følger trenere gjennom dette løpet og vurderer effekten av ulike oppfølgingsløp, vil kunne gi mer innsikt i hva slags trening som vil være mest effektiv også i utviklingen av mikropolitisk forståelse og evnen til orkestrering av deltakerne.

\section{Konklusjon og avsluttende tanker}

Denne undersøkelsen har sett nærmere på begrepet orkestrering og mikropolitisk kompetanse gjennom å søke kunnskap om hvordan erfarne trenere som har «overlevd» $\mathrm{i}$ bransjen over flere tiår har samhandlet med sine overordnede og medarbeiderne i klubbene de har vært i. Resultatene indikerer at orkestrering og mikropolitisk kompetanse er svært viktige deler av treneryrket, selv om det ikke har fått stor oppmerksomhet i tidligere forskning på coaching.

For det første syntes trenerne å være enige om at forskjeller i mål og verdier blant personene i og rundt klubbene kunne være en stor kilde til 
konflikt og tvetydighet i de forventningene partene har i utgangspunktet, og også for selve jobbutførelsen, noe som er i tråd med litteraturen rundt orkestringsmetaforen (Jones et al., 2013; Jones \& Wallace, 2005). Deltakerne ser ut til å oppleve treneryrket som en kompleks og utfordrende aktivitet, men kanskje ikke i like stor grad som noen av de tidligere studiene blant annet Jones og kolleger (2013) refererer til. Trenere i denne studien la stor vekt på å ha god kommunikasjon med både overordnede og medarbeidere fra dag én i klubben. Dette forhindret at mange potensielle problemer oppstod.

Et annet funn var at trenerne følte seg svært forpliktet til å gi hjelp til sine assistenter, og stolte på dem ved å delegere ansvar og fremme selvstyre. Ingen av trenerne forsøkte å skildre seg selv som karismatiske, allmektige ledere foran sine ansatte. I stedet valgte de en mer subtil og diskret tilnærming til egen rolle. Dette er helt i tråd med litteraturen om orkestrering, som fremmer det å styre, skape og styrke incitamenter for å påvirke folk til å gjøre det du vil at de skal gjøre (Jones et al., 2013, Jones \& Wallace, 2005, 2006).

Trenerne understreket også betydningen av å identifisere de mektigste interessentene i klubben og bygge gode relasjoner til dem. Dette inkluderte å finne ut hva disse menneskene forventet fra treneren samt tilpasse sin oppførsel til disse forventningene. Dette, blant mange andre funn, indikerer at de tre trenerne har godt utviklet mikropolitisk kompetanse, både i kunnskapsaspektet og i det instrumentelle aspektet (Kelchtermans \& Ballet, 2002a), noe man forventer av høyt meritterte trenere. Resultatene viser at trenerne bevisst engasjerer seg i mikropolitisk aktivitet for å bedre arbeidsforholdene og få det de ønsker ut av andre mennesker.

\section{Praktiske implikasjoner og begrensninger ved studien}

Det å se at trenerne i denne studien hevdet å ha lært mye av veiledning, kan være et godt råd for unge trenere. Å engasjere erfarne trenere og bruke dem som mentorer eller diskusjonspartnere for unge trenere vil kanskje være fruktbart for begge parter. En studie av Erickson, Bruner, MacDonald og Coté (2008) så på kanadiske treneres foretrukne og faktiske kilder 
til trenerkunnskap, og et av de viktigste funnene var at de 44 trenerne $ø$ nket langt mer veiledning enn de ville få i den fremtidige utdanningen sin. Basert på dette vil det virke fornuftig for nasjonale trenerforbund å legge til rette for mer veiledning gjennom mentorordninger. Alle får da muligheten til å lære av hverandres erfaringer. Denne typen av formelle vs. uformelle læringsmuligheter kan stimuleres ved å organisere det som kalles «praksisfellesskap» (Wenger, McDermott, \& Snyder, 2002). Det er et sted hvor folk som deler felles interesse eller yrke, møtes og diskuterer erfaringer og handlinger på en uformell, men strukturert måte. Som beskrevet av Culver og Trudel (2008) har studier vist at praksismiljøer kan være en god læringsplass for trenere, gitt at fellesskapsmøtene ledes av en kompetent tilrettelegger og at trenerne er villige til å dele sin kunnskap med hverandre. Organisering av slike miljøer kan være en god måte for fotballklubber eller trenerforbund å skape et utviklende miljø på - for å fremme sin mikropolitiske kompetanse.

Denne studien baserer seg på hvordan tre meget erfarne profesjonelle fotballtrenere beskrev arbeidet med sine overordnede og medarbeidere. En svakhet med denne studien er at det kun er tre trenere som danner grunnlaget for analysen, men på samme tid er dette noen av de mest erfarne trenerne i Norge og Skandinavia for øvrig. Selv om de har mye erfaring, er det vanskelig å generalisere ut over disse, og nye studier med lignende respondenter er derfor anbefalt. Siden studien også handler om disse trenernes opplevelser og erfaringer, er det vanskelig å si noe konkret om hva de faktisk gjør. Studier som undersøker flere topptrenere - gjerne gjennom observasjon, og over tid - er derfor anbefalt, selv om det etter vår erfaring kan være en gruppe det er vanskelig å få avtaler med på grunn av reiser og en tett kalender. Oppsummert har de fleste tidligere undersøkelser sett på hvordan trenere samhandler med spillerne, mens man har undersøkt viktigheten av å håndtere de politiske aspektene ved å være toppleder $\mathrm{i}$ idrett. Denne undersøkelsen baner derfor vei for fremtidig forskning på de måtene en elitetrener bereder jobben på, ikke bare på feltet, men også med tanke på hvordan man overlever på sikt i en resultatdrevet sektor.

Anerkjennelse: Vi ønsker å takke vår venn og kollega Øystein Røynesdal for verdifulle bidrag til denne studien. 


\section{Referanser}

Abrahamsen, F.E. \& Gitsø, E.O. (2016). Den coachende treneren - om å coache viderekomne. Oslo: Akilles.

Allen, J.B. \& Shaw, S. (2013). An Interdisciplinary Approach to Examining the Working Conditions of Women Coaches. International Journal of Sports Science and Coaching, 8(1), 1-18.

Arnulf, J.K., Mathisen, J.E. \& Hærem, T. (2012). Heroic leadership illusions in football teams: Rationality, decision making and noise-signal ratio in the firing of football managers. Leadership, 8(2), 169-185.

Ball, S.J. (1987). The micro-politics of the school: Towards a theory of school organization. London: Methuen.

Bentzen, M., Lemyre, P.-N. \& Kenttä, G. (2017). A Comparison of High-Performance Football Coaches Experiencing High- Versus Low-Burnout Symptoms Across a Season of Play: Quality of Motivation and Recovery Matters. International Sport Coaching Journal, 4(2), 133-146.

Bentzen, M., Lemyre, P.-N. \& Kenttä, G. (2014). The process of burnout among professional sport coaches through the lens of self-determination theory: a qualitative approach. Sports Coaching Review, 3(2), 101-116.

Bentzen, M., Lemyre, P.-N. \& Kenttä, G. (2016a). Changes in Motivation and Burnout Indices in High-Performance Coaches Over the Course of a Competitive Season. Journal of Applied Sport Psychology, 28(1), 28-48.

Bentzen, M., Lemyre, P.-N. \& Kenttä, G. (2016b). Development of exhaustion for high-performance coaches in association with workload and motivation: A person-centered approach. Psychology of Sport and Exercise, 22, 10-19.

Berg, B.L. (2007). Qualitative Research Methods for the Social Sciences. Pearson/Allyn \& Bacon.

Bird, M.L. (2003). High school football coaches and stress (Unpublished master's thesis). University of Wisconsin-Stout, Menomonie, WI.

Blase, J. (1991). The Politics of Life in Schools: Power, Conflict, and Cooperation. Newbury Park, CA.: Sage.

Capel, S.A., Sisley, B.L. \& Desertrain, G.S. (1987). The relationship of role conflict and role ambiguity to burnout in high school basketball coaches. Journal of Sport Psychology, 9, 106-117.

Chroni, S.A., Abrahamsen, F., \& Hemmestad, L. (2016). To Be the Eye Within the Storm, I Am Challenged Not Stressed. Journal of Applied Sport Psychology, 28(3), 257-273.

Chroni, S., Diakaki, E., Perkos, S., Hassandra, M. \& Schoen, C. (2013). What stresses coaches in competition and training? An exploratory inquiry. International Journal of Coaching Science, 7,25-39. 
Cruickshank, A. \& Collins, D. (2012a). "Change Management: The Case of the Elite Sport Performance Team”, Journal of Change Management, 12(2), 209-229.

Cruickshank, A. \& Collins, D. (2012b). Culture Change in Elite Sport Performance Teams: Examining and Advancing Effectiveness in the New Era. Journal of Applied Sport Psychology, 24(3), 338-355.

Culver, D. \& Trudel, P. (2008). Clarifying the Concept of Communities of Practice in Sport. International Journal of Sports Science and Coaching, 3(1), 1-10.

Elo, S. \& Kyngäs, H. (2008). The qualitative content analysis process. Journal of Advanced Nursing, 62(1), 107-115.

Erickson, K., Bruner, M.W., MacDonald, D.J. \& Coté, J. (2008). Gaining insight into actual and preferred sources of coaching knowledge. International Journal of Sports Science and Coaching, 3(4), 527-538.

Feltz, D.L., Chase, M.A., Moritz, S.E., Sullivan, P., \& Pressley, G.M. (1999). A Conceptual Model of Coaching Efficacy: Preliminary Investigation and Instrument Development. Journal of Educational Psychology, 91(4), 765-776.

Fletcher, D., \& Hanton, S. (2003). Sources of Organizational Stress in Elite Sports Performance. The Sport Psychologist, 17, 175-195.

Frey, M. (2007). College coaches' experiences with stress- "Problem solvers" have problems, too. The Sport Psychologist, 21, 38-57.

Gearity, B.T. \& Murray, M.A. (2011). Athletes' experiences of the psychological effects of poor coaching. Psychology of Sport and Exercise, 12(3), 213-221.

Goffman, E. (1955). On face-work: An analysis of ritual elements in social interaction. Psychiatry, 18(3), 213-231.

Goffman, E. (1959). The presentation of self in everyday life. New York: Doubleday.

Goffman, E. (1969). Strategic interaction. Philadelphia: University of Pennsylvania Press.

Gould, D., Carson, S., \& Blanton, J. (2013). Coaching Life Skills. I P. Potrac, W. Gilbert \& J. Denison (red.), Routledge Handbook of Sports Coaching (s. 259-270). London \& New York: Routledge.

Hsieh, H.-F. \& Shannon, S.E. (2005). Three approaches to qualitative content analysis. Qualitative health research, 15(9), 1277-1288.

Jones, B., Wells, L., Peters, R. \& Johnson, D. (1993). Guide to effective coaching: Principles and practice (3rd ed.). Boston: WCB McGraw-Hill.

Jones, R.L. (2009). Coaching as caring (the smiling gallery): accessing hidden knowledge. Physical Education \& Sport Pedagogy, 14(4), 377-390.

Jones, R.L., Bailey, J. \& Thompson, A. (2013). Ambiguity, noticing and orchestration. Further thoughts on managing the complex coaching context. I Potrac, P., Gilbert, W. \& Edison, J. (red.), Routledge handbook of sports coaching (s. 235-246). London: Routledge. 
Jones, R.L. \& Wallace, M. (2005). Another bad day at the training ground: Coping with ambiguity in the coaching context. Sport, Education and Society, 10(1), 119-134.

Jones, R.L. \& Wallace, M. (2006). The coach as 'orchestrator'. I Jones, R.L. (red.), The Sports Coach as Educator (s. 51-64). London: Routledge.

Kavussanu, M., Boardley, I.D., Jutkiewicz, N., Vincent, S. \& Ring, C. (2008). Coaching Efficacy and Coaching Effectiveness: Examining Their Predictors and Comparing Coaches' and Athletes' Reports. The Sport Psychologist, 22(4), 383-404.

Kelchtermans, G. \& Ballet, K. (2002a). Micropolitical literacy: reconstructing a neglected dimension in teacher development. International Journal of Educational Research, 37(8), 755-767.

Kelchtermans, G. \& Ballet, K. (2002b). The Micropolitics of Teacher Induction: A narrative-biographical study on teacher socialisation. Teaching and Teacher Education, 18(1), 105-120.

Knight, C.J., Reade, I.L., Selzler, A.M. \& Rodgers, W.M. (2013). Personal and situational factors influencing coaches' perceptions of stress. Journal of Sports Science, 31(10), 1054-1063.

Kristiansen, E., Abrahamsen, F.E., \& Pedersen, P.M. (2017). Media Behavior in Sport The Organizational Psychology of Sport: Key Issues and Practical Applications (s. 193-213): Routledge.

Kristiansen, E., Tomten, S., Hanstad, D.V. \& Roberts, G.C. (2012). Coaching communication issues with elite female athletes: Two Norwegian case studies. Scandinavian Journal of Medicine \& Science in Sports, In print.

Kroll, W. \& Gundersheim, J. (1982). Stress factors in coaching. Coaching Science Update, 23, 47-49.

League Managers Association (2016). End of Season Manager Statistics, 2015/16 season Retrieved from: http://www.leaguemanagers.com/documents/44/LMA_ End_of_Season_Report_and Statistics_2015-16.pdf Last retrieved: February $6^{\text {th }}$ 2017

Levy, A., Nicholls, A, Marchant, D. \& Polman, R. (2009). Organizational stressors, coping, and coping effectiveness: A longitudinal study with an elite coach. International Journal of Sports Science \& Coaching, 4, 31-45.

Malete, L. \& Feltz, D.L. (200o). The Effect of a Coaching Education Program on Coaching Efficacy. The Sport Psychologist, 14(4), 410-417.

McCalla, T. \& Fitzpatrick, S. (2016). Integrating sport psychology within a highperformance team: Potential stakeholders, micropolitics, and culture. Journal of Sport Psychology in Action, 7(1), 33-42.

McNeill, K., Durand-Bush, N. \& Lemyre, P.-N. (2016). Understanding coach burnout and underlying emotions: a narrative approach. Sports Coaching Review, $1-18$. 
Nelson, L., Cushion, C. \& Potrac, P. (2013). Enhancing the provision of coach education: the recommendations of UK coaching practitioners. Physical Education and Sport Pedagogy, 18(2), 204-218.

Olusoga, P., Butt, J., Hays, K. \& Maynard, I. (2009). Stress in elite sport coaching: Identifying stressors. Journal of Applied Sport Psychology, 21, 442-459.

Olusoga, P., Butt, J., Maynard, I. \& Hays, K. (2010). Stress and coping: A study of world class coaches. Journal of Applied Sport Psychology, 22, 274-293.

Olusoga, P., Maynard, I., Hays, K. \& Butt, J. (2012). Coaching under pressure: A study of Olympic coaches. Journal of Sport Sciences, 30, 229-239.

Potrac, P. \& Jones, R.L. (2009a). Micro-Political Workings in Semi-Professional Football. Sociology of Sport Journal, 26(4), 557-577.

Potrac, P. \& Jones, R.L. (2009b). Power, Conflict and Cooperation: Toward a Micropolitics of Coaching. Quest, 61(2), 223-236.

Potrac, P., Jones, R.L., Gilbourne, D. \& Nelson, L. (2012). 'Handshakes, BBQs, and bullets': self-interest, shame and regret in football coaching. Sports Coaching Review, 1(2), 79-92.

Purdy, L. \& Jones, R.L. (2011). Choppy Waters: Elite Rowers' Perceptions of Coaching. Sociology of Sport Journal, 28(3), 329-346.

Purdy, L., Potrac, P. \& Jones, R.L. (2008). Power, consent and resistance: an autoethnography of competitive rowing, Sport, Education and Society, 13(3), 319-336.

Relvas, H., Littlewood, M., Nesti, M., Gilbourne, D. \& Richardson, D. (2010). Organizational Structures and Working Practices in Elite European Professional Football Clubs: Understanding the Relationship between Youth and Professional Domains, European Sport Management Quarterly, 10(2), 165-187.

Santos, S., Jones, R.L. \& Mesquita, I. (2013). Do Coaches Orchestrate? The Working Practices of Elite Portuguese Coaches. Research Quarterly for Exercise and Sport, 84(2), 263-272.

Sparkes, A.C. \& Smith, B. (2013). Qualitative research methods in sport, exercise and health: From process to product: London: Routledge.

Sullivan, P. \& Kent, A. (2003). Coaching Efficacy as a Predictor of Leadership Style in Intercollegiate Athletics. Journal of Applied Sport Psychology, 15(1), $1-11$.

Sullivan, P.A. \& Nasham, H.W. (1993). The 1992 United States Olympic Team sport coaches: Satisfactions and concerns. Applied Research in Coaching and Athletics Annual, 8, 1-14.

Theobald, C.J. (1991). An investigation of stress factor as perceived by head high school basketball coaches in the state of Minnesota (Unpublished master's thesis). Minnesota State University. 
Thelwell, R.C., Weston, N.J.V., Greenlees, I.A. \& Hutchings, N.V. (2008). Stressors in elite sport: A coach perspective. Journal of Sports Sciences, 26, 905-918.

Thompson, A., Potrac, P. \& Jones, R. (2015). 'I found out the hard way': micropolitical workings in professional football, Sport, Education and Society, 2o(8), 976-994.

Wallace, M. (2003). Managing the Unmanageable?: Coping with Complex Educational Change. Educational Management Administration \& Leadership, 31(1), 9-29.

Wallace, M. \& Pocklington, K. (2002). Managing Complex Educational Change: Large scale Reorganisation of Schools. London: Routledge.

Wallinus-Rinne, A. (2016) (red.). Ungdomstreneren: rollen, lederen og fagpersonen Ungdomstreneren (s. 15-45): Akilles forlag.

Wegge, K.A. (2002). An examination of burnout among current high school head varsity girls' basketball coaches (Unpublished master's thesis). Bemidji State University, Bemidji, MN.

Wenger, E., McDermott, R.A. \& Snyder, W. (2002). Cultivating communities of practice: A guide to managing knowledge: Harvard Business Press.

$\mathrm{Wu}, \mathrm{Y}$. (1991). Role stress and secondary school teacher/coaches in the state of Washington (Unpublished master's thesis). Washington State University.

Zourbanos, N., Haznadar, A., Papaioannou, A., Tzioumakis, Y., Krommidas, C. \& Hatzigeorgiadis, A. (2016). The Relationships Between Athletes' Perceptions of Coach-Created Motivational Climate, Self-Talk, and Self-Efficacy in Youth Football. Journal of Applied Sport Psychology, 28(1), 97-112. 


\title{
KAPITTEL 5
}

\section{Miljøets betydning i elitesport}

\section{Et holistisk økologisk case studie af det nationale træningscenter i badminton}

\section{Carsten Hvid Larsen ${ }^{\star}$ Louise Kamuk Storm, \& Kristoffer Henriksen}

\author{
Institut for Idræt og Biomekanik, Syddansk Universitet, Odense, Denmark
}

\begin{abstract}
Resumé: De seneste år har der været stigende fokus på miljøets betydning for udvikling af eliteidrætsudøvere. Det er sket ud fra en erkendelse af, at hvis man ønsker at forstå de faktorer, der medvirker til eller begrænser en udøvers sportslige udvikling, er det ikke nok kun at studere den enkelte atlet, men hele miljøet, som udøveren udvikler sig i. Formålet med dette kapitel er at undersøge, hvad der karakteriserer et succesfuldt eliteidrætsmiljø $i$ dansk badminton, dvs. et eliteidrætsmiljø, der kontinuerligt formår at skabe seniorresultater på højeste internationale niveau og vinde medaljer ved EM, VM og OL. Undersøgelsen var et casestudie af eliteidrætsmiljøet i Badminton Danmark (BD). Der er indsamlet data fra interviews med spillere, trænere og ledere, observationer under træning og turneringer, interne møder og analyse af dokumenter. Miljøet var centreret omkring en selvforståelse baseret på "os mod resten af verden”, og en grundlæggende værdi i miljøet var at skabe intelligente spillere og samtidig have fokus på individuel udvikling igennem høj træningskvalitet. Organisationskulturen var konstrueret som: 1) et veldokumenteret, kvalitetsorienteret og dialogbaseret læringsmiljø, 2) et miljø med hård intern konkurrence og 3 ) et miljø med nære rollemodeller.
\end{abstract}

Nøgleord: badminton, sportspsykologi, elitesport, talentudvikling, organisationspsykologi

\begin{abstract}
In recent years there has been an increased focus on the importance of the environment for the development of elite athletes. In order to understand the factors that contribute to or limit an athlete's sporting development, it is not enough to study only the individual but the whole environment in which the athlete develops. The purpose of this chapter is to investigate what characterizes a successful elite sport environment in Danish badminton. An elite sports environment that continuously manages to create senior results at the highest international level and win medals at the European championships, the World championships and the Olympics. The study was organized as a case study of the national elite sports center in Badminton Denmark (BD). Data was based on interviews with players, coaches and managers, observations on training and in competitions, meetings and analysis of documents. The environment was centered on self-understanding based on "us against the rest of the world"
\end{abstract}

\footnotetext{
*Korresponderende forfatter: Carsten Hvid Larsen, Institut for Idræt og Biomekanik, Syddansk Universitet, Odense, Denmark, Campusvej 55, 5230 Odense, Denmark. Tel: 00453131 0111, Fax: 00456550 3480, E-mail: chlarsen@health.sdu.dk

Sitering av denne artikkelen: Larsen, C.H., Storm, L.K., \& Henriksen, K. (2018). Miljøets betydning i elitesport: Et holistisk økologisk casestudie af det nationale træningscenter i badminton. I T. Haugen \& R. Høigaard (Red), Trender i idrettspsykologisk forskning i Skandinavia (Kap. 5, s. 103-119). Oslo: Cappelen Damm Akademisk. DOI: https://doi.org/10.23865/noasp.39.ch5

Lisens CC-BY 4.0
} 
and a fundamental value in the environment was to create intelligent players while focusing on individual development through high training quality. The organizational culture was characterized by being: 1) a well documented, quality oriented and dialogue-based learning environment, 2) an environment with hard competition and 3) an environment with proximal role models.

Keywords: badminton, sport psychology, elite sport, talent development, organizational psychology

\section{Introduktion}

I de senere år er der kommet et øget fokus på at se på miljøets betydning for talentudvikling. At se på miljøet som en faktor i talentudvikling har dog ikke været en tilgang, der har præget forskningen. Forskningen har igennem årene været domineret af henholdsvis at se på talent som noget medfødt (nature) eller et spørgsmål om antallet af træningstimer som afgørende for udvikling (nurture). I forlængelse af disse tidligere trends indenfor talentforskning så er det i dag muligt at identificere tre sammenhængende, men forskellige perspektiver i forståelsen af talent, nemlig et biologisk, et psykologisk og et socialt perspektiv. Hvert af disse perspektiver angiver også en retning for, hvordan trænere eller andre praktikere (fx sportspsykologiske konsulenter) arbejder med den unge atlet i talentudviklingsprocessen (Stambulova, 2009). For det første er der det biologiske perspektiv, hvor talent refererer til en atlets medfødte potentiale eller begavelse ( $\mathrm{fx}$ antropometriske data, muskelstruktur) (Stambulova, 2009). I dette perspektiv arbejder trænere og praktikere med identifikation og udvælgelse af de atleter, der har størst potentiale for succes. For det andet er der et psykologisk perspektiv, der anser talent som atleternes erhvervede evner, kompetencer og færdigheder, der ligger til grund for atletens præstation og understøtter transitionen til eliteniveau (Stambulova, 2009). I det psykologiske perspektiv vil trænere og praktikere undersøge den optimale vej for en atlet til eliteniveau med hensyn til specialisering og forskellige typer træning. De to første perspektiver afspejler "nature versus nurture"-debatten i sportspsykologi (Stambulova, 2009). Endelig kan talent forstås i forhold til interaktioner i det specifikke talentudviklingsmiljø. Hvad kendetegner miljøer og programmer, der formår kontinuerligt at producere top-level-atleter (Henriksen, Stambulova, \& Roessler, 2011)? De seneste år har der været stigende fokus på miljøets betydning 
for udvikling af eliteidrætsudøvere. Det er sket ud fra en erkendelse af, at hvis man ønsker at forstå de faktorer, der medvirker til eller begrænser en atlets sportslige udvikling, er det ikke nok kun at studere den enkelte atlet isoleret, men hele miljøet, som atleten udvikler sig $\mathrm{i}$.

Formålet med dette kapitel er at undersøge, hvad der karakteriserer succesfulde eliteidrætsmiljøer, dvs. eliteidrætsmiljøer, der igen og igen formår at skabe seniorresultater på højeste internationale niveau og kontinuerligt vinde medaljer ved EM, VM og OL. Miljøet i denne undersøgelse afviger fra tidligere forskning, da fokus ikke kun er på at undersøge talenter, men også eliteatleter i miljøet. Undersøgelsen bygger på tidligere modeller for at beskrive miljøet (Henriksen, Roessler, \& Stambulova, 2010a; 2010b; 2011).

Henriksen og kollegaers (2010a; 2010b; 2011) holistiske økologiske tilgang beskriver miljøet som en række komponenter, der interagerer på forskellige niveauer eller lag, såkaldte mikro- og makromiljøer indenfor atletik, kajak og sejlads. I de senere år er der med udgangspunkt i den holistiske økologiske tilgang foretaget lignende studier indenfor håndbold (Storm, 2015) og fodbold (Larsen, Alfermann, Henriksen, \& Christensen, 2013). I den holistiske økologiske tilgang illustreres miljøet ved et centrum (mikromiljøet), der spreder ringe ud i omkringliggende og perifere miljøer, som i varierende grad og ofte indirekte påvirker atleten i centrum af mikromiljøet. Det handler om at se på atletens relation til træneren, skolen, familien og klubben. Disse miljøer har hver især en betydning i sig selv, men relationerne er også vigtige. Som et konkret eksempel kan nævnes, at et godt og fleksibelt samarbejde mellem skolen og klubben kan gøre hverdagen lettere for atleten og bidrage til øget fokus på træning i hverdagen. Derudover er der makromiljøet (sociale sammenhænge), som atleten ikke direkte indgår i, men som alligevel påvirker atleten. Det kan fx være uddannelsessystemet med fleksible eller rigide eksamensordninger. Miljø-modellen beskriver relationer og roller i det enkelte miljø, men ikke baggrunden for miljøets succes. Miljø-succesfaktormodellen beskriver, hvordan miljøets forskellige forudsætninger (økonomi, trænere, materiel) påvirker processen i miljøet (træning, træningslejre, konkurrence), som tilsammen påvirker individets udvikling og organisationskulturen. Disse faktorer er afgørende for miljøets succes. Den holistiske økologiske tilgang 
adskiller sig således fra den biologiske og psykologiske tilgang til talent og er baseret på hele miljøet. Miljøet som helhed spiller en afgørende rolle for udvikling og succes i miljøet. Det er med andre ord en nyere trend, hvor det ikke længere er nok at studere den enkelte atlet isoleret, men hele miljøet må medtages for at beskrive eliteidrætsmiljøer.

\section{Metode}

\section{Introduktion til miljøet}

Badminton Danmark (BD) har igennem 50 år formået at producere idrætsudøvere, der kunne gøre sig gældende på højeste internationale niveau i en meget kompetetiv idrætsgren, hvor især lande i Asien investerer massivt og har langt flere ressourcer, både befolkningsmæssigt og $ø$ konomisk, end Danmark. På trods heraf har Danmark formået at holde sin placering blandt de tre bedste lande i verden og har igennem de seneste 10 år vundet adskillige VM-medaljer og taget medaljer ved de olympiske lege i 1996, 2000, 2004 og 2012. BD lever derfor op til kriterierne for et succesfuldt eliteidrætsmiljø.

\section{Undersøgelsens baggrund}

Undersøgelsen blev foretaget som et kvalitativt orienteret casestudie. Maaløe (2004) definerer et casestudie som en "empirisk undersøgelse, der undersøger fænomener i sin virkelige kontekst" (s. 5). Casestudiet er en strategi til empirisk at udforske udvalgte nutidige fænomener i deres naturlige sammenhæng ved hjælp af flere datakilder (Robson, 2002). Et casestudie giver forskerne mulighed for at undersøge holistiske og meningsfulde begivenheder (Yin, 2009) og er brugbart i undersøgelser, hvor mange forskellige variabler kan påvirke resultaterne, og hvor det ikke er muligt at kontrollere disse variabler (Kruuse, 2008). Af disse grunde var casestudiet et passende metodologisk valg for denne undersøgelse. Undersøgelsen har været en "en kontinuerlig dialog mellem teorier, genererede data og vores fortolkning, hvilket forhåbentlig vil føre til en mere komplet forståelse af miljøet (Maaløe, 2004). Førsteforfatteren fik igennem Team Danmark kontakt til BD. En repræsentant fra Team Danmark, sportschefen og en landstræner 
fra $\mathrm{BD}$ og førsteforfatteren mødtes derefter og afklarede undersøgelsens formål. Efterfølgende aftalte førsteforfatteren med landstræneren, hvornår undersøgelsen ville starte og dens varighed. Undersøgelsen af BD er baseret på data fra flere forskellige områder: 1) 11 semi-strukturerede interviews med sportschef, landstrænere, unge talenter, elitespillere og en tidligere landsholdsspiller, 2) deltagerobservation under træning, interne møder (mellem sportschef og trænere), kamptræning, briefing før kamp (mellem træner og spiller), til turnering / kamp (Denmark Open) og opsamling og feedback efter kamp (mellem træner og spiller) (i alt 84 timer i miljøet) og 3) analyse af dokumenter, artikler, træningsplaner, sæsonplaner, live TV fra turneringer, elitestrategi og interne dokumenter i BD.

\section{Resultater}

\section{Beskrivelse af BD som elitemiljø}

Denne undersøgelse fokuserede på BD’s elitespillere og professionelle afdeling, som til daglig er i Idrættens hus i Brøndby, og er omdrejningspunkt for beskrivelse af den empiriske miljø-model af BD (figur 1, empirisk model af miljøet i BD). De empiriske modeller af BD, der bliver præsenteret i resultatafsnittet, bygger på Henriksen og kollegaers (2010a) holistiske økologiske arbejdsmodeller af henholdsvis relationer og roller i miljøet og de faktorer, der ligger til grund for succes i miljøet. I betragtning af at alle dele af miljøet er indbyrdes forbundne og påvirker hinanden, viser modellen de vigtigste komponenter og forbindelser såvel som strukturen af miljøet. Tykkelsen af pilene svarer til graden af forholdet, og overlap af komponenter (cirkler) viser tætte relationer og samarbejde i hverdagen, et eksempel kunne være forbindelsen mellem staben i Badminton Danmark og sportschef og team af trænere. Beskrivelsen af miljøet vil være centreret om det sportslige domæne i mikromiljøet. For at fremme læsevenligheden er begreber som 'elitetræningsmiljøet' forkortet til 'miljøet' og spillere, der er relativt 'nye' på træningen og med potentiale til på sigt at begå sig på internationalt topplan, som 'talenter'. Alle relevante medarbejdere i Badminton Danmark, der til hverdag har at gøre med atleterne, er beskrevet som 'Staben i Badminton Danmark', og alle ressourcepersoner udefra bliver betegnet som 'Eksperter'. 


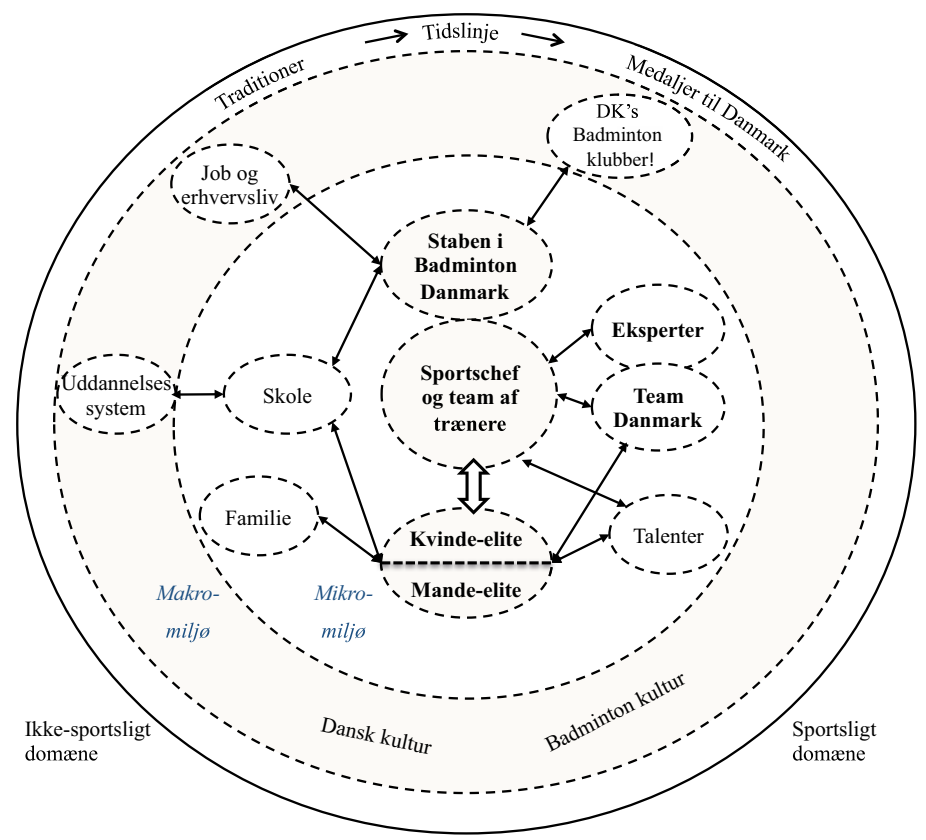

Figur 1. Empirisk model af $\mathrm{BD}$-elite.

I centrum i modellen er der en akse af relationer fra staben, sportschef og team af trænere til kvinde- og mandeelitespillere og repræsenterede tætte og vigtige relationer i mikromiljøet.

\section{Stab i Badminton Danmark}

Herunder var de organisatoriske kræfter placeret. De medarbejdere der sørgede for bookning af baner, bolde og andre praktiske gøremål. Staben var i dialog med sportschefen for at forsøge at få hverdagen til at glide så let som muligt. Træningsvejlederne, der er tilknyttet Badminton Danmark, var placeret her. Relationen mellem staben og sportschefen var meget tæt, hvilket gav en stærk forbindelse direkte til spillerne.

\section{Sportschef og team af trænere}

Omdrejningspunktet i miljøet var en meget stærk relation mellem trænerteamet og sportschefen i Badminton Danmark. Sportschefen havde været tilknyttet Badminton Danmark siden starten af 1990'erne og 
havde haft forskellige ansvarsområder bl.a. uddannelse af elitetrænere, talenttræner, landstræner, udenlandsk landstræner og sportschef og nu sportschef i DK. Trænerteamet bestod af to mandlige hovedtrænere på fuldtid og en kvindelig og en mandlig træner på deltid. To af de mandlige trænere havde tidligere spillet på divisionsniveau i Danmark, den tredje havde spillet nationale og internationale turneringer, og den kvindelige træner havde tidligere deltaget på højeste internationale niveau, herunder OL. De to hovedtrænere havde været tilknyttet Badminton Danmark som landstræner eller assistent i hhv. 21/2 og 6 år. På trods af position og anciennitet så fremstod trænerne som et team med et fladt hierarki. Sportschefen var af den opfattelse, at den enkelte træner skulle blive udfordret af de andre i gruppen og være nødt til at argumentere, hvilket ikke ville være tilfældet med en enerådig landstræner. Udover at den enkelte træner diskuterede beslutninger med de andre, gav det også mulighed for at dele viden og undgå indforståethed hos den enkelte træner, som sportschefen sagde:

"For det første bliver landstroneren skarp $i$, hvad det er, han kigger efter og hvorfor det er, at han dømmer, som han dømmer. De andre de fär at høre, hvad det er for nogle ting, der bliver langt til grund og de andre kan byde ind med, har du tonkt over det her, har du set det her. Så derfor så føler jeg, at man kan sige, at når man kommer til beslutningsfasen, så er det en velinformeret beslutning, eller en beslutning på et fornuftigt grundlag. Folk kan vore uenige, og vi kan også udvikle en indforståethed $i$ vores egen snak osv., men jeg synes, det bearbejder det på sådan en måde, at det er det bedste."

Trænerteamet arbejdede tæt sammen med Team Danmark, og gennem dette samarbejde modtog de bl.a. informationer om de aftaler, spillerne kunne have med eksperter udenom Team Danmark, herunder kan nævnes diætister, mentaltrænere, fysiske trænere, fysioterapeuter osv.

\section{Kvinde-/mandeelitegruppen}

Den primære målgruppe var spillere blandt eller med umiddelbart potentiale til at være blandt verdensranglistens 10 bedste spillere/par og 
spillere, der var relevante på Thomas- og Uber Cup-holdet. Andre spillere med internationalt potentiale, ambitioner og mod egen betaling, kunne efter nærmere aftale medvirke med det formål at skærpe konkurrencen, intensiteten og variationen i træningen. Selve antallet af spillere varierede fra dag til dag, da nogle spillere kunne være til turneringer rundt omkring i verden, mens andre var i træningslokalet.

Spillerne havde en tæt relation til trænerne, der mindede om en fladt hierarki. Trænerne beskrev også, at de prøvede at skabe et samarbejde, hvor trænerne ikke bare dikterede, men prøvede at skabe nogle rammer, hvori spilleren kunne få lov at reflektere over egen udvikling. Udover at den enkelte spiller eller par havde en hovedtræner tilknyttet (fx som singlespiller), så havde den enkelte spiller også en relation til de andre i trænerteamet. I flere tilfælde ville den enkelte spiller ikke have egen hovedtræner med til turneringer i udlandet og kunne således stadig få feedback fra en anden træner. Denne tætte kontakt med forskellige trænere i trænerteamet blev anset som er en styrke og havde en betydning for læring, som sportschefen beskrev:

"Vi er ydmyge omkring opgaven og ydmyge omkring, at der er ikke nogen, der har den endegyldige sandhed på det her (red. udvikling og resultater). Vi kan ikke skrive en bog, der siger, sådan bliver du verdensmester i badminton, fordi der kan vore forskellige veje. Det udvikler sig hele tiden, så når vi er fordige med bogen, så er det noget nyt, der er galdende."

Som figur 1 viser, så fremstod gruppen af elitespillere opdelt mellem mandeelite og kvindeelite, som også viste sig i interviews og observationer. Relationerne internt i mandeelitegruppen var på trods af hård intern konkurrence præget af en villighed til at dele viden og hiælpe hinanden i træningen uanset position i hierarkiet, hvor observationerne viste, at dygtigt spil blev anerkendt af den direkte modstander. Denne tilgang synes dog ikke entydigt at være gældende hos kvindeeliten, som flere af de interviewede kvindeelitespillere bemærkede, og trænerne bemærkede i uformelle samtaler med førsteforfatteren. En kvindeelitespiller beskrev, hvilken betydning det kan have for miljøet, når der ikke er fokus på læring og videndeling. Hun beskrev, at de interne konflikter skabte: "et dårligt træningsmiljø, at der er nogen af de her grupper blandt pigerne, der 
ikke kan trone sammen, og som skaber splid, og som lidt hader hinanden og på ingen måde gider at hjoelpe hinanden.”

\section{Talenter}

Miljøet omfattede også en gruppe af unge talenter, der havde potentiale til at indgå på lige fod med de etablerede spillere. Disse spillere indgik også i relationer, der omfattede trænerteamet, herunder sportschefen og Team Danmark, dog uden økonomisk støtte fra Team Danmark. Talenterne måtte som alle andre bevise og etablere deres position i miljøet igennem progression og resultater.

\section{Badmintonklubber i Danmark en central komponent i makromiljøet}

Klubnetværket i Danmark var enormt godt, og som en af hovedtrænerne beskriver: "en af grundpillerne i dansk badminton er, at der bliver gjort så stort et arbejde, og der er sådan et højt vidensniveau ude i klubberne, og at der er velfungerende klubber så mange steder rundt om i landet, at vi samler talenterne op.” Trænerteamet var også i dialog med klubberne, hvis træningsmængden skulle nedjusteres i klubberne op til en stor turnering, hvor forbundet havde store mål for den enkelte spiller. Udover et stærkt klubnetværk har sportschefen, grundet hans mange år med uddannelse af trænere i DK (se også under sportschef), også været med til at skabe badmintonkulturen i DK. Sportschefens historie i Dansk Badminton havde derfor også en central betydning for miljøet i BD, og han havde haft berøring med miljøet i forhold til træneruddannelse for mange år siden, som var grundlaget for talentudviklingen i klubberne, og derudover tidligere fungeret som landstræner i BD.

\section{Uddannelse, job og erhvervsliv}

Trænerteamet, som havde den daglige kontakt med spillerne, var som udgangspunkt ikke involverede i jobsituationen. De kunne dog være involverede i diskussionen omkring det økonomiske grundlag for at deltage på træningen. Derudover havde de fleste spillere et job ved siden af som adspredelse og understøttelse af karrieren. 


\section{Identifikation af succesfaktorer i BD}

Figur 2 (den empiriske udgave af miljø-succesfaktormodellen) opsummerer de faktorer, der påvirker BD's succes som miljø. Nedenfor præsenterer vi de vigtigste faktorer i forbindelse med forudsætninger, proces, spillernes individuelle udvikling og resultater og organisationskulturen og til sidst, hvordan det påvirker miljøets succes.

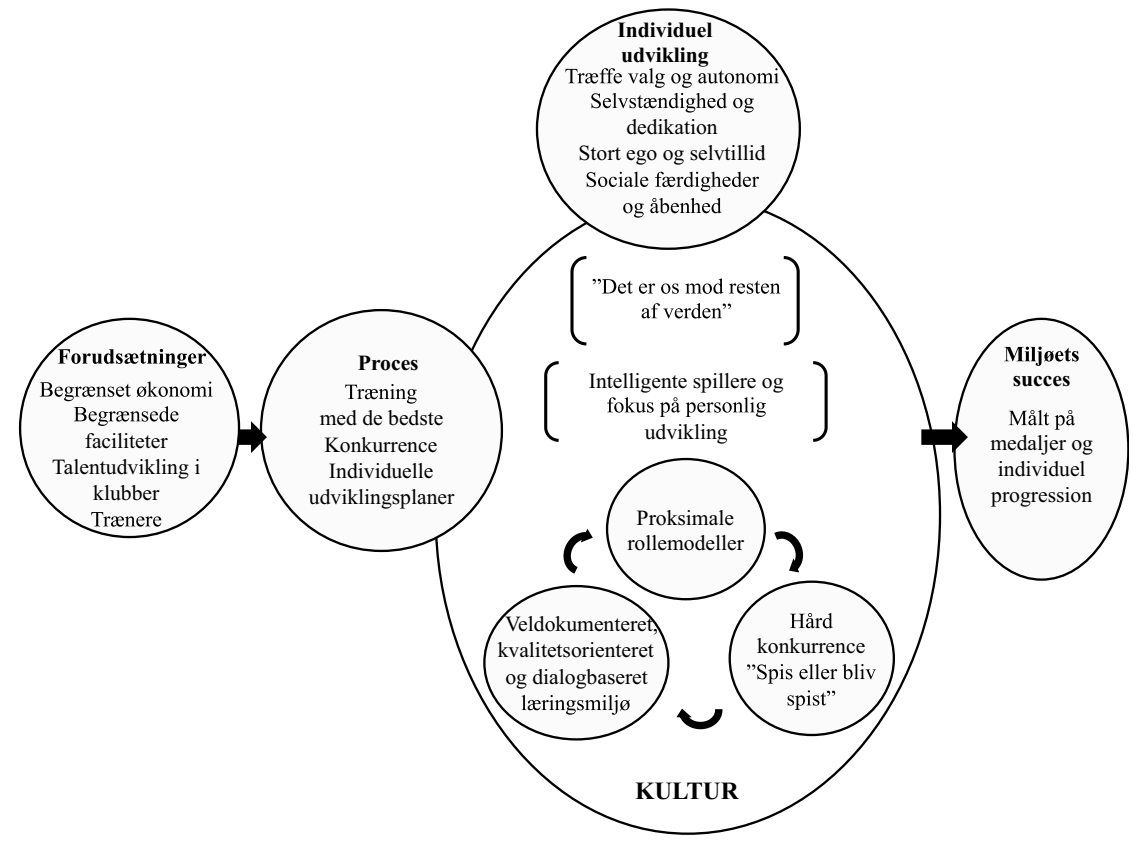

Figur 2. BD's succesfaktorer.

\section{Forudsætninger}

Trænere og sportschefen nævnte alle, at der var begrænset økonomi i $\mathrm{BD}$, og faciliteterne var heller ikke i top i forhold til konkurrenterne. Nogle af de mangler, der fremkom under interviews, var ifølge trænere og spillere basale ting som restitutionscenter, løbebane, træningscenter ved banerne, egen hal og dårligt underlag (på grund af at hallen også bliver brugt til andre idrætsgrene). Men på trods af at de dårlige faciliteter, som også ifølge ledelsen kunne være bedre, så beskrev spillerne ikke, at det havde en nævneværdig betydning i forhold til deres præstationer, 
som en ung spiller beskriver: "Vi har jo klaret os rigtig godt indtil nu[...] vi klarer os på en anden måde. Så det tror jeg faktisk også er en styrke. Vi prosterer bedre fordi det har vi bare altid gjort." Talentudviklingen $\mathrm{i}$ de danske badmintonklubber blev beskrevet som en stor resurse. Talentudviklingen foregik i klubberne, hvorefter spillerne centraliseredes i det nationale træningscenter Brøndby, så snart de nåede et vist niveau, som var landsholdsaktuelt. Dette betød, at de flyttede til København for at træne med de bedste spillere i landet. Trænerne blev ligeledes beskrevet som en væsentlig resurse. Sportschefen havde også bevidst sammensat trænerteamet ud fra forskellige kompetencer. Alle trænerne havde mange års erfaring som trænere, men forskellig baggrund. Én af dem havde en universitetsuddannelse, to af dem var tidligere spillere, og den sidste var træner-uddannet, hvilket tilsammen dannede et solidt grundlag og en bredere indsigt i de daglige udfordringer og udviklingen af den enkelte spiller.

\section{Proces}

Miljøet og træningen handler om andet end gentagelser og antal timer på træningsbanen for at nå verdenstoppen. Trænerne var dygtige til at motivere, skabe en positiv stemning og ønskede at skabe spillere, der kunne tænke og træffe valg på banen. Store dele af træningen foregik i dialog med spillerne. Spillerne er til mange nationale og internationale konkurrencer i løbet af året. I løbet af dagene i Brøndby var der ikke mange gange, hvor alle spillere var til stede, fordi spillerne på forskellige tidspunkter skulle deltage i turneringer i forskellige dele af verden. Dette påvirkede dog ikke kvaliteten i træningen, og udover træningskvalitet så beskrev en tidligere spiller noget om danske spilleres konkurrencementalitet som en central komponent i BD's succes:

"Når man spiller kamp mod hinanden, så er du ikke venner mere. Og det er ham derovre, der vil slå dig, og du vil gøre alt, selvom det er en almindelig onsdag aften $i$ Brøndby som alle andre, så vil du gøre alt. Og der kan godt komme diskussioner og skænderier, hvis du mener, han har snydt på linjen og så videre, og så er du måske sur fem ti minutter efter. Men dagen efter, så er alt glemt. Så er 
alt ved det gamle, og man troner mod det samme mål. Den ting er en ting, som mere eller mindre er umulig at skabe andre steder, fordi man ikke har forståelse for, at det er okay. Det er en klar forskel, som jeg har oplevet fra det system, jeg er $i$ u, hvor vi prøver at søge den intensitet, den villighed til at ville vinde ligegyldigt hvad."

\section{Kulturen}

Miljøets kultur bestod af tre lag: Artefakter, Skuevordier og Basale Antagelser. Artefakter var tydelige organisatoriske strukturer og processer, såsom fysiske elementer i træningslokalet, logoer, bygninger, materielle objekter. Voerdier er sociale principper, normer, mål og standarder, som organisationen viser til verden, de eksisterer i hovedet på dens medlemmer og tjener som synlige motivationer og begrundelser for handlinger. Basale antagelser er underliggende årsager til handlinger. De består af overbevisninger og antagelser, der ikke længere sættes spørgsmålstegn ved og tages for givet.

Artefakterne i BD var ikke altafgørende for kulturen. Dog kan det nævnes, at et fysisk artefakt i form af et stort banner kunne findes i en af træningshallerne med teksten: "Os mod resten af verden", som også anvendtes af en træner, som sagde: "vores store ordsprog, det er jo os mod verden. Det er at vi hele tiden udfordrer på, at det, vi skal gøre, skal vore målt med de bedste."

Skuevordierne i BD var et ønske om at udvikle intelligente spillere og samtidig have fokus på individuel udvikling igennem høj troningskvalitet. Sportschefen gav et indblik i, hvad han gerne ville frembringe i de danske spillere:

" [...] men vi vil også gerne udvikle dem til at voere selvstondige spillere, hvor man klarer sig selv og dermed det element, der er at udvikle sig selv, det ligger meget mere $i$ systemet, eller $i$ sagens natur, end hvis det er, vi tager os af dem[...] altså udviklingsmål[...] vi skal udvikle nogle spillere, der kan, tør og vil."

En anden træner beskrev yderligere om forståelsen for at udvikle intelligente spillere, der skulle kunne træffe uafhængige beslutninger: "Dem 
der tør at overraske til sidst $i$ kampene og så $i$ øvrigt har niveauet til at komme hen til sidst i kampene mod de bedste, det er dem, der vinder." Den individuelle udvikling var et centralt begreb i miljøet og lagde op til autonomi, selvstændighed, dedikation og sociale evner, i og med kommunikation var et vigtigt redskab for at have styr på præstationerne til træning og i konkurrence.

Der eksisterede tre indbyrdes afhængige basale antagelser i miljøet: 1) Veldokumenteret kvalitetsorienteret og dialogbaseret loringsmiljø, 2) Hård konkurrence -’spis eller bliv spist' og 3) Proksimale rollemodeller. Samspillet mellem de tre antagelser var med til at definere miljøet i BD.

1) Veldokumenteret kvalitetsorienteret og dialogbaseret loeringsmiljø var et omdrejningspunkt og knyttet til sportschefen og trænerteamet. For at opretholde et miljø i verdensklasse var der et solidt dokumenteret grundlag for de beslutninger, som blev taget og var kontrolleret af sportschefen. Informationerne blev skabt igennem dialog mellem træner og sportschef, og alle detaljer blev noteret og ført ind i profiler for den enkelte spiller, såsom skader, spilkoncept, kost/ernæring, teknisk/taktisk/fysisk/mental udvikling og mål. Dette grundlag kaldes af sportschefen 'systemiske virkemidler' og skulle, som navnet antyder, skabe et system til bedre og begrundede valg og handlinger i forhold til den enkelte spillers progression eller mangel derpå. De systemiske virkemidler var måden, hvorpå der blev truffet beslutninger.

'Hård konkurrence - spis eller bliv spist'var den anden basale antagelse, der lå til grund for miljøet. Hvis spilleren ikke kunne leve op til kravene sat af trænerne og sportschefen, så var de klar til at finde en erstatning eller lave om på konstellationer i double / mix. Igen var det klart fra den daglige ledelse, hvordan det forholdt sig med den hårde konkurrence, som en tidligere spiller beskrev:

"Jamen altså kulturen den er jo hård. Det er jo spis eller bliv spist-agtigt. Altså der er ikke plads til svaghed i løbet af de fem dage, du er i Brøndby. Så må du tage hjem og slikke dine sår $i$ weekenden. Men de dage der, så er der en kultur, der siger altså, det er de storkeste, der overlever." 


\section{'Proksimale rollemodeller'}

Træningen var præget af spillere med internationalt niveau, som var aktivt deltagende på træningen, og dermed var de indirekte og (u)bevidste med til at skabe idoler og rollemodeller i forhold til, hvordan der skulle trænes. Det blev underbygget af en af trænerne, som sagde: "en af vores storke ting er også, at vi hele tiden, i-gennem generationer, har haft rollemodeller $i$ vores system[...] Og det er vigtigt, at de rollemodeller også forstår deres roller. Og tager del i det ansvar, det er at vere rollemodel." Rollemodellerne i miljøet var også centrale for kvaliteten i træningen og havde været det i mange år, hvilket kan være en årsag til, at BD har været mange år i verdenseliten. Udover at talenter og yngre spillere dagligt så deres rollemodeller, så lærte de også, hvad det krævede at nå verdenseliten, men også omkring rollen som hjælper i træningsøvelser, og dermed lærte de unge spillere sociale færdigheder, som en spiller beskrev:

"Fx er Gade er rigtigt god til at få sin oploegger til at voere god, fordi man har en respekt om Gade. Det ville selvfølgelig vore perfekt, hvis man havde det for alle spillere på samme måde, men Gade han har voret herinde i, jeg ved ikke hvor mange år, og han har bare voret den bedste i rigtig lang tid, så hvis man skal ind og logge op på hans bane, så skal du bare se en forskel i oploeggeren. Den er virkelig klar, for hvis man laver en fejl, når man er sammen med Gade, så får man det at vide. Og når Gade så lægger op til én, så får man også bare sindssygt gode oplog, så det er sådan det der med, at man skal voere god til at logge op til de andre, dem der er bedre end en selv, det er faktisk det, man også selv bliver bedre af, så lige så snart man kommer herind, så har man sindssygt store forudsatninger for at blive rigtig god, men det er én selv, der skal gøre det sidste."

\section{Individuel udvikling}

Elitespillerne udviklede en lang række færdigheder, der var medvirkende til deres succes i badminton. Dataanalysen viste, at spillerne blev dygtige til 1) at træffe valg og autonomi (nødvendigt for at kunne træffe valg i kampen), 2) at være selvstændige (nødvendigt at vide hvordan du skal træne eller balancere fritid og sport), 3) at være dedikerede (der er ikke nødvendigvis mange penge i sporten, så som en træner siger, skal du "være pioner"), 4) at få et stort ego og selvtillid (nødvendigt hvis du skal 
overleve i miljøet og spille mod de bedste i verden), 5) at udvikle sociale færdigheder og åbenhed (for at kunne hjælpe hinanden i øvelser og give feedback selv om man er konkurrenter). I vores observationer viser der sig et billede af trænere, der er dygtige til at motivere, skabe en positiv stemning, og som ønsker at skabe spillere, der kan tænke og træffe valg på banen, som en af de observerede beskriver:

"Det er første dag, jeg er $i$ Brøndby og observere træningen $i$ BD. Jeg blev taget godt imod af tranerne, som kort introducerede mig for spillerne. Stemningen er afslappet, og der er godt humør, og trænerne griner og har det sjovt, før træeningen starter. På trods af den løse stemning er der seriøsitet, når trceningen starter. Der bliver varmet op med løb rundt $i$ hallen, hvorefter der spilles et opvarmningsspil, hvor også trænerne spiller med, hvis der mangler en spiller i træningsøvelsen. Spillerne og tronerne splitter herefter op i grupper i forhold til single og double med hver deres træner. I løbet af troningen er der meget dialog i øvelserne mellem troner og spiller. I en kampsituation har en af trcenerne fokus på en af de unge spillere. I løbet af en halv time er troneren henne og snakke med den unge spiller $i$ hvert spilstop. Måden de kommunikerer på er ikke instruerende, men proget af specifik, konstruktiv og anerkendende feedback efterfulgt at konstruktive kommentarer undervejs i øvelsen."

\section{Miljøets succes}

Når BD evaluerer sin succes, så var de primære dele af ligningen resultater og individuel progression. Resultaterne var vigtigst, og BD havde klare mål for mål og medaljer. Det var dog også vigtigt for $\mathrm{BD}$ at have spillere i verdenstoppen, og spillernes progression blev målt i resultatmål og deres evne til at rykke op på verdensranglisten.

\section{Refleksioner omkring den holistiske økologiske tilgang}

Formålet med dette kapitel var at undersøge, hvad der karakteriserede et succesfuldt eliteidrætsmiljø, der igen og igen formåede at skabe seniorresultater på højeste internationale niveau og kontinuerligt vinde medaljer ved EM, VM og OL. Når vi ser på resultaterne i dette kapitel, er der 
store ligheder med tidligere forskning indenfor succesfulde miljøer. I lighed med denne forskning besidder $\mathrm{BD}$ også støttende træningsgrupper, mulighed for at blive inkluderet i et træningsfællesskab, læringsmiljø, konstruktiv kommunikation fra trænere og det omgivende nærmiljø, nære rollemodeller og træningsgrupper med både unge og eliteatleter og en stærk og sammenhængende organisationskultur. BD afviger dog fra tidligere forskning i succesmiljøer ved at være et miljø, der inkluderer både talenter og eliteatleter - altså et decideret elitemiljø. Der, hvor BD afviger fra anden forskning er ved fokusset på resultater og individuel progression, nødvendigheden af et netværk af talentudviklingsmiljøer og et veldokumenteret, kvalitetsorienteret grundlag for interne beslutninger og opfyldelse af mål for spillere og ledere i organisationen.

At arbejde ud fra en holistisk økologisk tilgang adskiller sig fra en klassisk sportspsykologisk tilgang. Den økologisk tilgang åbner nye muligheder og inspirerer trænere og praktikere, ikke kun til at arbejde med den enkelte atlets sportslige udvikling, men at være opmærksom på, analysere og arbejde for at skabe et miljø, der støtter atleters udvikling. At skabe og fastholde en stærk og sammenhængende organisationskultur og behandle atleter som hele mennesker kan skabe grundlag for udvikling af en pakke af psykosociale færdigheder, som vil være til nytte for atleter ikke kun i deres sport, men også i deres liv uden for sporten. En træner eller praktiker, der arbejder fra et økologisk perspektiv, arbejder ikke kun med de individuelle atleter, men har til formål at optimere hele miljøet omkring atleten eller teamet og styrke relationerne og dialogen mellem de forskellige dele af miljøet: mellem de unge spillere, de professionelle spillere og den sportspsykologiske konsulent og træneren.

\section{Litteratur}

Henriksen, K., Stambulova, N., \& Roessler, K.K. (2010a). A Holistic approach to athletic talent development environments: A successful sailing milieu. Psychology of Sport and Exercise, 11, 212-222.

Henriksen, K., Stambulova, N., \& Roessler, K.K. (2010b). Succesful talent development in track and field: Considering the role of environment. Scandinavian Journal of Medicine \& Science in Sports, 20, 122-132. 
Henriksen, K., Stambulova, N., \& Roessler, K.K. (2011). Riding the Wave of an Expert: A Successful Talent Development Environment in Kayaking. The Sport Psychologist, 25, 341-362.

Kruuse, E. (2008). Kvalitative forskningsmetoder[Qualitative Research Methods]. (6 ed.) Copenhagen: Dansk Psykologisk Forlag.

Larsen, C.H., Alfermann, D., Henriksen, K., \& Christensen, M.K., (2013). Successful talent development in soccer: The characteristics of the environment. Sport, Exercise and Performance Psychology, 13, 2157-3905.

Maaloe, E. (2004). In Case of Case Research. (Working paper 2004-9 ed.) Aarhus, Denmark: Department of Organization and Management, Aarhus University.

Patton, M.Q. (2002). Qualitative evaluation and research methods. Newsbury Pard, CA: Sage Publications.

Robson, C. (2002). Real World Research. Oxford: Blackwell.

Stambulova, N. (2009). Talent development in sport: A career transitions perspective. I E. Tsung-Min Hung, R. Lidor, \& D. Hackfort (Eds.), Psychology of sport excellence (pp. 63-74). Morgantown, WV: Fitness Information Technology.

Storm, L.K. (2015). Coloured by Culture: Talent Development in Scandinavian Elite Sport as seen from a Cultural Perspective. PhD afhandling. Institut for idræt og biomekanik, Syddansk Universitet, Odense.

Yin, R.K. (2009). Case Study Research: Design and Methods. (4 ed.) Thousands Oaks, California: Sage Publications. 



\title{
KAPITTEL 6
}

\section{Idrætspsykologi med et community psykologisk afsæt}

\section{Erfaringer fra et socialt eksperiment i København, Danmark}

\author{
Knud Ryom ${ }^{\star} \&$ Reinhard Stelter \\ Københavns Universitet, Institut for Idræt og Ernæring
}

\begin{abstract}
Resumé: Det overordnede formål med dette studie var at undersøge, hvordan en handlingsrettet og community psykologisk tilgang påvirkede et socialt udsat boligområde og deltagernes opfattelse af sig selv og hinanden (unge drenge, 12-16 år). I den forbindelse blev der samskabt (co-created) et socialt eksperiment over en toårig periode imellem forsker, praktikere og deltagere. En multi-method tilgang blev anvendt for at sikre socialt robust viden. Metoderne omfattede spørgeskemaer, interviews, feltarbejde og observationer. Gennem interventionsperioden blev der rapporteret flere resultater på baggrund af projektet, men vigtigst synes at være den community psykologiske tilgangs betydning for disse resultater. Den valgte tilgang kan anses for at have været det centrale fundament for projektets succes i forhold til at engagere unge drenge på kanten af samfundet i en fælles skabelsesproces. I denne artikel fokuseres på fordelene ved at benytte en community psykologisk tilgang, når man ønsker at arbejde med idrætspsykologi i et socialt udsat boligområde.
\end{abstract}

Nøgleord. aktionsforskning, community psykologi, samskabelse, socialt eksperiment

\begin{abstract}
The overall purpose of this study was to examine how a transformative and community psychological approach could affect a socially challenged neighbourhood and participants' perceptions of involvement (young boys, 12-16 years). A social research experiment lasting 2 years was co-created between researchers, practitioners and participants. A multi-method approach was used to ensure that thorough and socially robust knowledge was produced. Methods used included questionnaires, interviews, fieldwork and observations. Although several notable results emerged throughout the intervention period, the most important results were related to the significance of the overall approach regarding these results. Despite the challenges faced by researchers, when engaging youth at the margins of society in a co-creation process, the approach seemed valuable. Giving the participants the possibility to engage themselves, through empowerment initiatives, seems to be a confounding reason for the success of the project. Hence, this article will focus upon the benefits of using a community psychological approach when working with exercise psychology in a socially deprived community.
\end{abstract}

Keywords. action research, community psychology, co-creation, social experiment *Korresponderende forfatter: Knud Ryom, Knud Ryom, Institut for Folkesundhed, Sektion for Idræt, Aar-
hus Universitet, Dalgas Avenue 4, 8000 Aarhus C, Danmark, E-mail: knudryom@ph.au.dk

Sitering av denne artikkelen: Ryom, K. \& Stelter, R. (2018). Idrætspsykologi med et community psykologisk afsæt: Erfaringer fra et socialt eksperiment i København, Danmark. I T. Haugen \& R. Høigaard (Red), Trender i idrettspsykologisk forskning i Skandinavia (Kap. 6, s. 121-143). Oslo: Cappelen Damm Akademisk. DOI: https://doi.org/10.23865/noasp.39.ch6

Lisens CC-BY 4.0 


\section{indledning}

Idrætspsykologi, såvel som psykologi i almindelighed, er fagdiscipliner hovedsagligt præget af et individuelt fokus (personen sættes i centrum). Dermed er det i hovedreglen klienten, som er omdrejningspunktet, medførende at indsatser, forløb og interventioner tager udgangspunkt $i$ at løse individets udfordringer eller problemer med afsæt i dets opfattelse af verden. Desforuden bygger en række psykologiske teorier og megen forskning på en positivistisk videnskabsforståelse, hvorved sandheder og idealer opstilles som almengyldige (Reason \& Bradbury, 2008). Det kan fx påpeges, at moderne psykologiske tilgange, såsom dele af kognitionspsykologien, reelt inspireres af positivistisk videnskabsforståelse, især fordi der har været en tendens til at foretrække kvantitative undersøgelser og videnskabelse frem for andre undersøgelsestilgange (Berliner, Høffding, \& Hakesberg, 2005). Samlet set peger det på psykologien som en forskningstradition præget af et individuelt fokus (Orford, 2008).

Til nogen grad er idrætspsykologien i Skandinavien også præget af et individuelt fokus, hvor fx atleters life skills (planlægning, indre dialog etc.) ofte søges trænet gennem individuelle teknikker (Henriksen, Larsen, Storm, \& Ryom, 2014). Med amerikansk inspiration fra Mental Skills Training programmes (MST) (Danish, Taylor, Hodge, \& Heke,2004; Gould \& Carson, 2008), har life skills således haft en stor indflydelse på sportspsykologien igennem de senere år (Hardcastle, Glassey, Hagger, \& Tye, 2015). I modsætning til dette er en holistisk og økologisk bølge vokset frem i bl.a. Danmark og Sverige (Henriksen \& Stambulova, 2017), hvor fokus har været på kultur og miljø.

Som forfattere af denne artikel søger vi at supplere med en tilgang, der udvider bredden i den skandinaviske idrætspsykologi, ved at fremlægge et perspektiv, der sætter fokus på fællesskabet som dynamisk faktor til social forandring. Denne artikel tager derfor udgangspunkt i community psykologi ${ }^{1}(\mathrm{CP})$, som sætter fokus på personen i konteksten (Orford, 2008), hvorved vi mener at undgå en individualisering af sociale

Omtales også i nogle kredse som samfundspsykologi og i England undertiden som social therapy (Orford, 2008). Det ses som en tilgang associeret med og udsprunget af økologisk psykologi og aktionsforskning (Berliner, Høffding \& Hakesberg, 2005). 
problemstillinger. I CP søges det at placere dynamikker og fænomener, som traditionelt placeres 'indeni' personen, igennem en forståelse af en helhed af person og omgivelser (Berliner et al., 2005). Derfor lægges der vægt på den eller de livssituationer, en eller flere personer eller communities eller fællesskaber befinder sig i, som afgørende for udvikling.

Til trods for at de skandinaviske lande er kendetegnet ved et stærkt velfærdssystem, øges den sociale ulighed (især i Danmark), drevet af stigende indkomstforskelle imellem toppen og bunden af samfundet (Danmarks Statistik, 2015). Den øgede afstand medfører, at samfundets borgere i ringere grad interagerer med hinanden, hvorved det kan risikeres, at medlemmer i samfundet bliver fremmede for hinanden (Putnam, 2000). Samtidig viser undersøgelser, at især børn, unge og voksne med migrationsbaggrund har store vanskeligheder med uddannelse, job og aktiv deltagelse i samfundet (Danmarks Statistik, 2015).

Samfundsmæssige og lokale udfordringer, som de her beskrevne, er særligt interessante i et CP-perspektiv. CP tager udgangspunkt i bæredygtige og inddragende interventioner igennem praktisk arbejde i lokalmiljø og med deltagerne og er inspireret af aktionsforskning. En tilgang som synes at få stigende betydning for at løse bestemte samfundsbetingede udfordringer og mindske den sociale skævhed.

\section{Aktionsforskning}

For at forstå CP, er det mest befordrende at starte ved at give læseren en forståelse af aktionsforskning ${ }^{2}$. Målet med CP er nemlig at øge livskvalitet igennem kollaborativ forskning og handlinger, aktionsforskning er således fundamentet for denne type forskning (Orford, 2008).

At definere hvad aktionsforskning indebærer, og hvordan den bedrives, er en kompleks udfordring ${ }^{3}$, da tilgangen er opstået og sammensat af flere forskellige forskningsretninger (Brydon-Miller, Greenwood, \&

2 Aktionsforskning trækker på det deltagende forskningsparadigme (Heron \& Reason, 1997), hvilket dog ikke vil blive yderligere beskrevet i denne artikel.

3 En større uddybning af aktionsforskning vil ikke forefindes i denne artikel, da fokus vil blive lagt på CP. For mere uddybende information om aktionsforskning, kan henvises til SAGE Handbook of Action Research. 
Maguire, 2003; Duus, Husted, Kildedal, Laursen, \& Tofteng, 2014). Som en alment accepteret grundpræmis for denne forskningsretning kan følgende pointeres: Hvis et individ skal forandre sig, er sandsynligheden for dette større, hvis individet oplever (demokratisk) medbestemmelse og gøres ansvarlig i beslutningstagning (Nielsen \& Nielsen, 2015). En sådan grundpræmis medfører, at aktionsforskning beskæftiger sig med varig social forandring af en given lokal kontekst igennem fælles handlinger (Reason \& Bradbury, 2008). Handling, involvering og refleksion skal dermed forstås som centrale elementer i et handlingsrettet perspektiv, hvor processen støttes op omkring teori (bruges ofte som guidelines) og er indlejret i praksis i samarbejde med andre (Nielsen \& Nielsen, 2015). Det handler altså groft sagt om at involvere deltagerne i forskningsprocesser. Gennem forskellige former for samskabelse udvikler deltagere og forsker(e) fælles meninger og viden, der kan løse hverdagens udfordringer i fx et lokalmiljø. Aktions- og handlingsrettet forskning er fundamentet for $\mathrm{CP}$, fordi denne tilgang netop fokuserer på fællesskab, socialt samspil og et emancipatorisk perspektiv.

\section{Community psykologi}

Community psykologi (CP) som psykologisk tradition er udviklet med stærk inspiration fra og som en videreudvikling af aktionsforskning indenfor en psykologisk kontekst (Berliner et al., 2005; Orford, 2008). CP tilstræber teoretisk og praktisk at nå ud til de ofte "oversete" dele af befolkningen såsom marginaliserede, fattige og undertrykte (Berliner et al., 2005). Overordnet er ambitionen at udvikle en psykologisk forståelse på baggrund af de eksisterende sammenhænge, konstrueret af organisationsformer og forståelser/meninger, som gør sig gældende i lokalområde og samfund (Berliner et al., 2005). Vægten lægges på forståelse af helheden af individers livssituation med inspiration fra økologisk psykologi (Bronfenbrenner \& Morris, 2006). I CP bliver et fokus på relationen imellem individet og et eller flere miljøer særligt interessant. Denne relation er historisk influeret, det være sig gennem fx de værdier, meninger og handlemuligheder, som kendetegner det pågældende nær- eller lokalmiljø. I CP har lokalmiljøet således stor betydning for det enkelte individs 
muligheder og måder at handle på. Kloos og kolleger (2012) fremhæver dette ved at illustrere de mange og sammenvævede økologiske niveauer indenfor CP i figur 1. Hvert enkelt eller flere af disse niveauer kan være analyserammen for et studie, men det centrale er, at alle niveauer skal betragtes som indbyrdes afhængige og derfor må forstås som et hele.

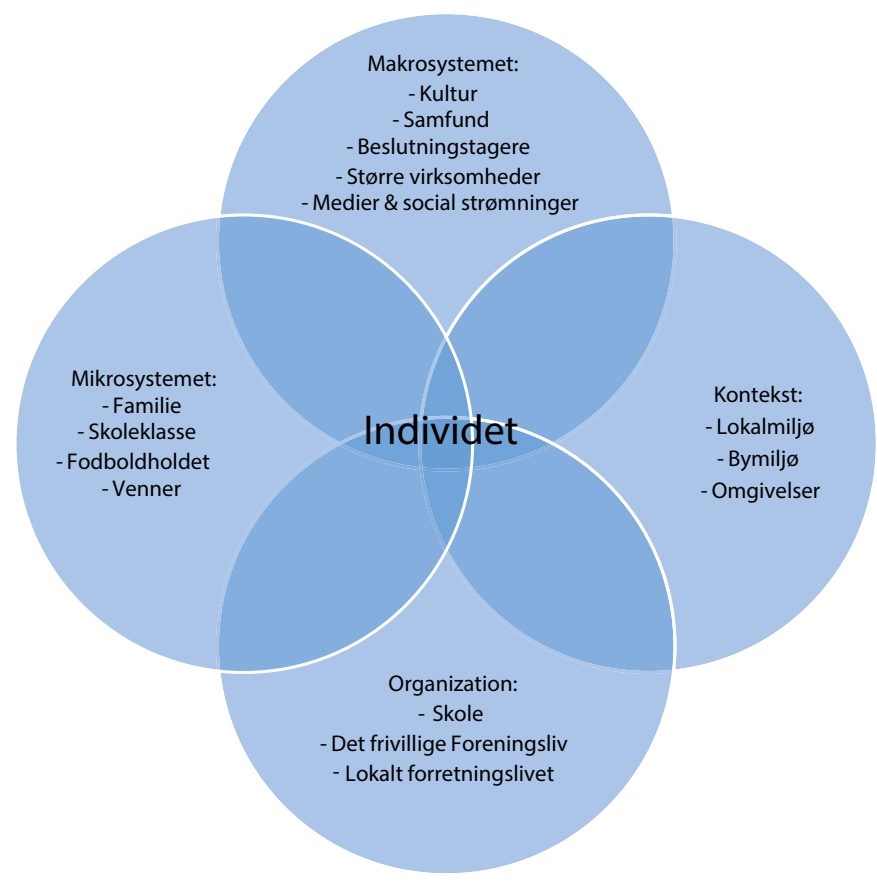

Figur 1. Illustration af de økologiske niveauer for analyse indenfor CP (Kloos et al., 2012, s. 19).

CP fjerner sig dermed fra et ensidigt fokus på individuelt niveau, som megen psykologisk teori og praksis som tidligere beskrevet er kendetegnet ved (Orford, 2008). Mange psykologiske traditioner anser det enkelte individ som centrum for psykologiske indsatser, mens CP ser lokalmiljøet og sociale faktorer som afgørende for psykologiske indsatser (Berliner et al., 2005) (jf. figur 1). Fra et psykologfagligt perspektiv søger CP således at gøre op med den stigende individualisering, som vi ser i samfundet i dag (Bauman, 2003; Beck, 2002; Giddens, 1997), blandt andet præget af en stigende psykologisering og indflydelse fra lægevidenskaben på 
samfundet (Berliner et al., 2005; Rose, 2000; Thualagant, 2011). Psykologien har sammen med lægevidenskaben til stadighed opnået stigende betydning i nutidens samfund (Rose, 2000). Denne betydning omtalte Foucault som den diagnostiske-terapeutiske relation, som er præget af det medicinske paradigme med sit fokus på at måle, veje og diagnosticere (Thualagant, 2011). Dette forhold beskrev Foucault med begrebet biomagt, som henviser til, hvordan viden bruges aktivt af beslutningstagere til (usynlig) magtanvendelse i det moderne menneskes liv. Det er bl.a. dette magtforhold, hvor borgere i stadig højere grad styres igennem usynlig magt, som CP forsøger at modarbejde ved at invitere deltagerne og lokalområdet ind i forskningsprojektet med fokus på empowerment ${ }^{4}$.

Rent formelt bedrives CP ideelt set med følgende forståelse (Orford, 2008):

a) Problemet ses som resultat af en udviklingsproces - en historisk proces, der påvirkes af den måde, social støtte og magt er udformet og fordelt på,

b) Analyseniveauet er person-i-kontekst, dvs., at den omfatter diskursive, sociale og materielle livsbetingelser,

c) Psykologisk indgriben skal placeres så tæt som muligt på de involverede brugeres dagligdag,

d) Indgriben er snarere forebyggelse og kompetenceopbygning end egentlig behandling,

e) Indgriben er pro-aktiv, dvs., at man går i dialog med nærmiljøet snarere end at afvente, at skaden er sket,

f) Indgriben baserer sig på, at den psykologiske fagviden stilles til disposition for alle involverede, og

g) Der ønskes samarbejde med forskellige faggrupper samt med ikkeprofessionelle.

Denne forståelse betyder, at community psykologen (forskeren) ofte agerer som supervisor og rådgiver med fokus på aktiv deltagelse i det

4 Empowerment kan forstås på følgende måde:"an intentional, ongoing process centered in the local community, involving mutual respect, critical reflection, caring, and group participation, through which people lacking an equal share of resources gain greater access to and control over those resources" (Kloos et al., 2012, s. 353). 
daglige miljø omkring det aktuelle projekt frem for som distanceret ekspert. Forsker(e) igangsætter sammen med deltagerne større sociale processer i et lokalområde ved at skabe ændringer, som i deres grundtanke giver det lokale fællesskab magt til at kontrollere beslutninger, politik og handleplaner, som det selv er involveret i. Kongstanken i CP er således, at individer og lokalområdet får mulighed for at udvikle færdigheder, som de selv efterspørger eller oplever at have behov for.

Det centrale omdrejningspunkt er altså personen-i-konteksten, og fra denne synsvinkel er det i konkrete livssammenhænge, hvor problemer og ressourcer reelt findes, også der, hvor praktiske perspektiver udvikles, og ressourcer inddrages. Derfor er community psykologer interesserede i ressourcer i form af måder, hvorpå der konstrueres løsninger, håb og sociale værdier i fællesskab (Berliner et al., 2005).

\section{Et eksempel på CP-forskning: Projekt unge, holdspil og medborgerskab}

I det følgende rettes fokus mod et konkret projekt, som forfatterne har været involveret i, og som bygger på en CP-tilgang. Denne introduktion skal give læseren en praktisk forståelse af tilgangen samt danne ramme om den efterfølgende diskussion af CP som mulig inspiration for idrætspsykologi i Skandinavien.

Mange bydele i Danmark har store sociale udfordringer med mandlige unge og deres evne til bl.a. at tage aktivt ansvar for deres egen livssituation. For at skabe nye perspektiver på unges liv tager projektgruppen afsæt i disse unge med henblik på at give dem mulighed for at opnå livskompetencer og gøre dem livsduelige gennem aktiv deltagelse i holdspil, forskellige sociale og faglige læringsaktiviteter samt coaching/mentoring. Dermed er der søgt konstrueret en arena for personlig og social udvikling i lokalmiljøet igennem et fælles tredjes.

5 Det fælles tredje refererer til produktet af et fælles forløb imellem forsker og deltagere, som udgør et nyt fælles vi. Det er således en arena, der er skabt i fællesskab mellem interessenter (Duus et al., 2014). 
Til forskel fra den gængse individfokuserede psykologiske forskning tages i dette projekt afstand fra top-down-processer. Projektet var rettet imod en deltagerorienteret forståelse, dialog og samskabelse af ny viden og byggede således på et samspil mellem forskere og aktører, hvor fokus var på arbejdet med menneskers livsnære problemer i deres konkrete hverdag (Reason \& Bradbury, 2008). Incitamentet bag tilgangen i dette projekt var at udvikle og udbygge empowerment i lokalmiljøet (med udgangspunkt i skolen og frivillige, lokale foreninger) og samtidig skabe rum for, at de enkelte deltagere oplevede at kunne tage vare på eget liv på nye måder (Cargo, 2003).

Med dette afsæt var det projektets formål at udvikle den enkelte deltagers livsduelighed, selvværd og personlige læringsevne (Cefai, 2009) samt at styrke den sociale sammenhængskraft blandt de involverede unge med tanke på på længere sigt at styrke den sociale kapital blandt de involverede og lokalmiljøet (Putnam, 200o). Det samlede forløb ansporede deltagerne til at udvikle nye fortællinger og refleksioner som en væsentlig støtte for dem i formuleringen af et fremadrettet livsprojekt (Berliner et al., 2005).

\section{Design af studiet}

Undersøgelsen og det samlede eksperiment ${ }^{6}$ var baseret på tre studier (figur 2), som alle blev afviklet over en 2-årig periode. De tre studier har været bearbejdet i en CP-ramme. På et værdiorienteret grundlag arbejdede forskere mod at udvikle eller øge udsatte gruppers autonomi igennem sociale handlinger (Orford, 2008). Målet var at skabe empowerment og sociale ændringer hos og omkring drengene. I praksis blev teoretisk viden sat i spil til udvikling af guidelines og idéer i en handlingsrettet tilgang, hvor samtlige deltagere har været en del af processen. Viden blev dannet i samspil mellem samtlige aktører, hvor oplevelsen og betydningen af eksperimentet blev vurderet med data fra flere metoder via multi-method-tilgangen (beskrives senere). Tabellen (tabel 1) giver indsigt i rammerne for de enkelte studier.

\footnotetext{
6 Ifølge Kurt Nielsen (2004) kan aktionsforskning forstås som den "moderne" afløser for eksperimentet i samfundsvidenskaben, dog uden sammenligning med klassiske eksperimenter. Derfor bruges betegnelsen eksperiment i denne artikel.
} 


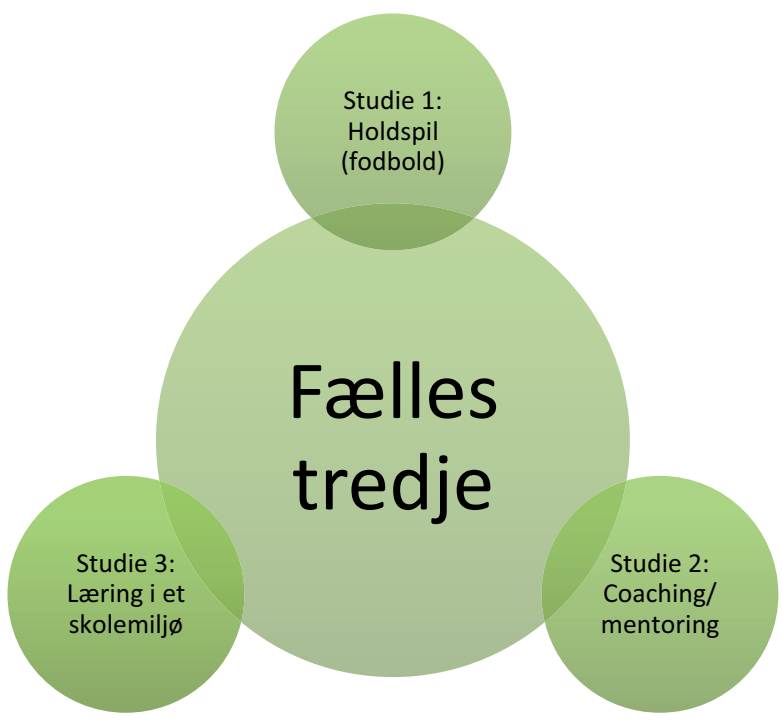

Figur 2. Illustration af de tre særskilt studier, som samlet dannede et fælles tredje for deltagerne.

Tabel 1. En uddybning af de tre studier i relation til antal deltagere, længde, involverede og metoder.

\begin{tabular}{|l|l|l|l|l|}
\hline Studie: & Holdspil/fodbold & $\begin{array}{l}\text { Coaching/ } \\
\text { mentoring }\end{array}$ & Læring & Partnerskole $^{7}$ \\
\hline Deltagere & $\mathrm{n}=45$ & $\mathrm{n}=80$ & $\begin{array}{l}\mathrm{n}=6 \\
\text { skoleklasser }\end{array}$ & $\mathrm{n}=49$ \\
\hline Længde & 2 år & 2 år & $\begin{array}{l}3 \times 1 \text { uge over } \\
2 \text { år }\end{array}$ & 2 år \\
\hline Involverede & $\begin{array}{l}\text { Klubleder og trænere } \\
\text { fra lokal fodboldklub, } \\
\text { elever, lærere, } \\
\text { skoleledelse (og } \\
\text { forældre) }\end{array}$ & $\begin{array}{l}26 \text { frivillige } \\
\text { coaches, } \\
\text { elever, lærere, } \\
\text { rollemodeller fra } \\
\text { lokalmiljøet og } \\
\text { skoleledelse }\end{array}$ & $\begin{array}{l}\text { Professionel } \\
\text { afvikler, elever } \\
\text { og lærere }\end{array}$ & Elever og lærere \\
\hline $\begin{array}{l}\text { Metoder til } \\
\text { monitorering } \\
\text { af proces og } \\
\text { rapportering }\end{array}$ & $\begin{array}{l}\text { Interviews, } \\
\text { observationer, } \\
\text { fokusgruppeinterviews } \\
\text { og spørgeskemaer }\end{array}$ & $\begin{array}{l}\text { Interviews, } \\
\text { observationer og } \\
\text { spørgeskemaer }\end{array}$ & $\begin{array}{l}\text { Interviews og } \\
\text { observationer }\end{array}$ & $\begin{array}{l}\text { Interviews og } \\
\text { spørgeskemaer }\end{array}$ \\
\hline
\end{tabular}

\section{Et fælles tredje}

I CP arbejdes der ofte med introduktion til aktiviteter, som kan udvikle sig til et fælles tredje for deltagerne. Det fælles tredje er et begreb hentet

7 Partnerskolen skal ikke forstås som et studie i sig selv, men som en art kontrolgruppe, som er med i tabellen, for at læseren kan danne sig et overblik over det samlede eksperiment. 
fra pædagogikken og hentyder til, at to eller flere mennesker mødes om en aktivitet, som alle involverede har interesse i (Husen, 1996). Ved at introducere en aktivitet, som har deltagernes interesse, opbygges et rum med muligheder, der over tid kan udvikle sig til et fællesskab. Den enkelte er i en sådan aktivitet i stand til at være individ i gruppen og har samtidig et tilhørsforhold, som kan udvikle sig til en fællesskabsfølelse blandt deltagerne (Husen, 1996).

I omtalte projekt med navnet "Unge, holdspil og medborgerskab" blev de to aktivitetsformer, ${ }^{8}$ fodbold og coaching, introduceret med henblik på at udvikle et fælles tredje. For fodbold gjaldt det, at et fysisk fællesskab kunne være rammen om sådan et fællesskab (Berliner et al., 2005). Imens coaching kunne være et reflekterende dialogisk fællesskab baseret på en 'ligeværdig' relation imellem coachene og deres unge samtalepartnere (Husen, 1996; Stelter, 2014).

At udvikle et fælles tredje er en central ambition for mange CP-projekter og et vigtigt værktøj i udviklingen af lokalmiljøer. Ved aktivt at arbejde med et nyt fælles tredje forsøgte projektet at frigøre sig fra den ekspertposition eller terapeutiske relation, som kan opstå i fx kvalitativ orienteret forskning (Kvale \& Brinkmann, 2009) Aktionsforskerne Ditte Tofteng og Mia Husted (2014) udtrykker det på følgende måde:

"Det foelles tredje er således et forsøg på ikke at efterstrcebe lighed $i$ roller og magt, hvilket noppe kan lade sig gøre, men i stedet arbejde med lighed som 'voice', dvs. lighed som det, at stemmer toeller" (Duus et al., 2014, s. 143).

\section{Deltagere og kontekst}

Skolen, som har været omdrejningspunkt for dette studie, er en dansk folkeskole, som ligger i lokalområdet Ydre Nørrebro, København. Ydre Nørrebro er efter danske forhold et spraglet område, karakteriseret af både velhavende, men også flere socioøkonomisk svagt stillede beboere (Hussain, 2014; Schmidt, 2016). I Danmark er socioøkonomisk status

8 Bemærk at den tredje intervention i projektet (jf. figur 2), læringsdelen, ikke blev igangsat som et fælles tredje, hvorfor det ikke beskrives her. 
defineret på baggrund af uddannelse, indkomst, bolig og arbejdsstatus. Området omkring Mjølnerparken, hvor hovedparten af deltagerne bor, defineres som et socioøkonomisk svagt lokalområde (Schmidt, 2011). Det er et område med meget socialt boligbyggeri og høj arbejdsløshed, især i Mjølnerparken. De deltagende drenges familiære baggrunde var hovedsageligt arabiske, som tegner sig for halvdelen af den samlede indvandrerbefolkning på Nørrebro (Schmidt, 2011). Nørrebro som lokalområde er kulturelt og demografisk meget blandet og er efter danske forhold meget tæt befolket (Schmidt, 2011). Området er kendt af vidt forskellige grunde: bandekriminalitet, socialt boligbyggeri, anarkister, religiøse fanatikere, højindkomstboliger, kunstnere og iværksættere (Schmidt, 2011; Schmidt, 2016).

\section{Processen}

Den praktiske proces er et essentielt perspektiv for ethvert CP-projekt. I $\mathrm{CP}$ arbejdes med levende faser i en dynamisk og kontinuerlig fremgangsmåde; kontinuerlig i den forstand, at processen i princippet aldrig har et fast defineret slutpunkt. ${ }^{9}$ Der igangsættes handlinger, som principielt kan fortsætte i det uendelige (Orford, 2008). På denne måde minder CP om participatory action research (PAR) i dens form (Reason \& Bradbury, 2008; Orford, 2008).

Der findes mange forskellige tilgange til proces i CP, og indenfor denne videnskabelige retning findes ingen gylden standard. Fremgangsmåden i projekt unge, holdspil og medborgerskab var inspireret af Bridget Somekhs (2008) arbejde med aktionsforskning indenfor læring. Baggrunden for dette valg var, at både Somekhs og det nærværende projekt tager udgangspunkt i en skole- og læringskontekst.

Figuren (figur 3) illustrerer processen, som overordnet deles i tre faser: 1) Forundersøgelse, 2) Socialt eksperiment og 3) Afrapportering. Bemærk at faserne ikke skal forstås som løsrevne, men dynamiske og sammenvævede.

9 Dette er et filosofisk grundprincip, men i realiteten har projekt unge, holdspil og medborgerskab af videnskabelige årsager været tidsbestemt. Dog fortsætter processen, efter projektteamet har forladt lokalmiljøet. 


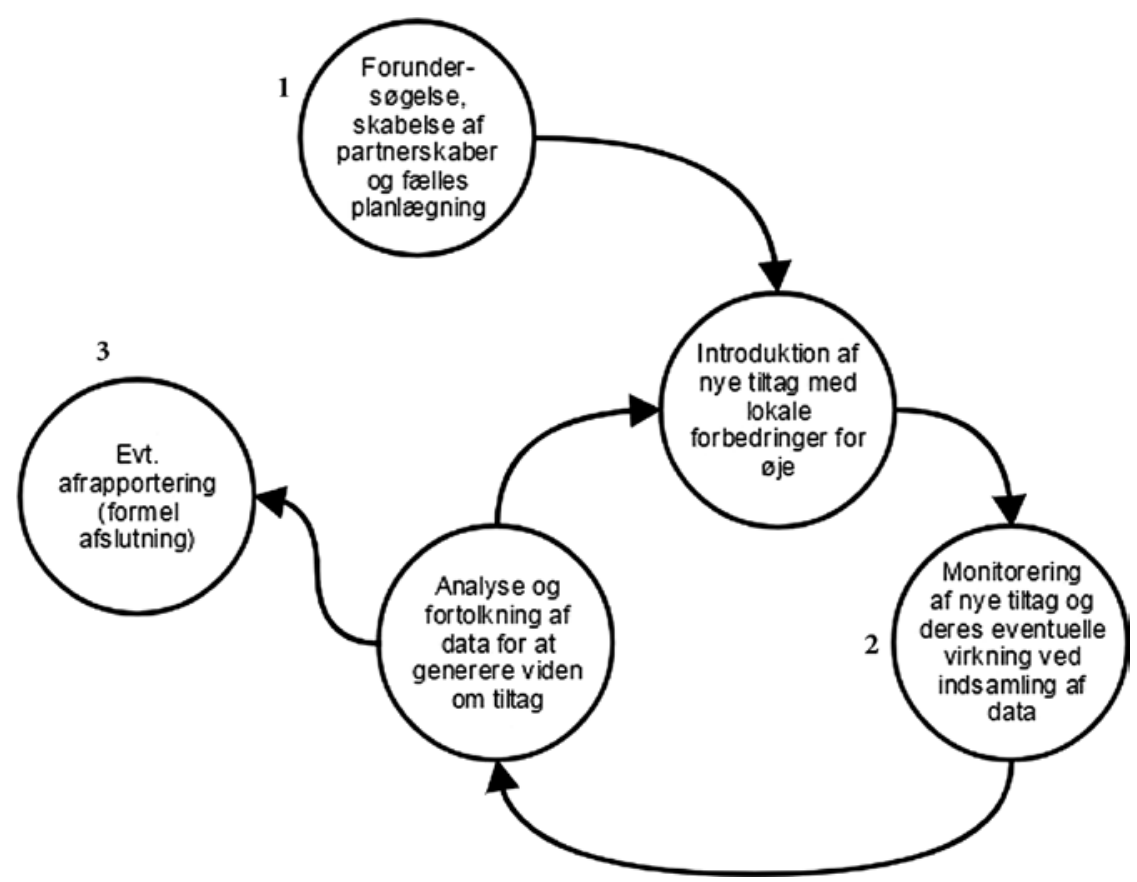

Figur 3. Illustration af processen i projekt unge, holdspil og medborgerskab.

Fase 1: Forundersøgelsen handler om det arbejde, som gik forud for det egentlige sociale eksperiment. I forbindelse med dette projekt fandt et større feltarbejde sted for at skabe et solidt kendskab til lokalmiljøet og for at få adgang til en for forskerne anden kultur (Thorpe, 2012; Willis, 1993). Til dette blev der lagt vægt på begrebet thick participation, som formuleret af den tyske antropolog Gerd Spittler (2001; 2014). Ifølge Spittler (2014) handler thick participation om at være i lære i praksis med naturlige samtaler og observationer, levede erfaringer og sansemættet forskning. Dermed søges kulturel viden registreret i forskerens egen krop og først senere eksternaliseret i form af data. Begrebet ligner thick description (Geertz, 1973) i kraft af fokus og vægt på detaljer, men søger i højere grad deltagelsen og deling af sociale oplevelser (Ryom, 2017). Efterfølgende blev partnerskaber dannet med relevante aktører i lokalmiljøet, og en fælles planlægning af forløbet blev udført med alle involverede inden opstart af selve eksperimentet (Reason \& Bradbury, 2008).

Fase 2: Det sociale eksperiment (Nielsen, 2004) og de enkelte studier (figur 2 og tabel 1) blev herefter igangsat, monitoreret via flerstrengede 
metodestrategier, efterfulgt af analyse og fortolkning for at generere ny viden om tiltaget. Herefter gentoges cyklussen med eventuelle tilpasninger af tiltaget på baggrund af ny viden og deltagernes redefinering i en kontinuerlig proces igennem en toårig periode.

Fase 3: Den formelle afslutning af projektet var i form af afrapportering, bl.a. via denne artikel, samt fælles produktion ${ }^{10}$ og øvrige videnskabelig publikationer (Ryom, 2017; Ryom, Andersen, \& Stelter, 2017; Ryom, Stelter, \& Plannthin, 2014).

\section{Metode}

I unge, holdspil og medborgerskab blev en multi-method-tilgang benyttet for at sikre en omfattende forståelse af et komplekst projekt, og det som Agergaard (2015) karakteriserede som et vildt problem. En sådan tilgang benyttes ofte inden for CP, sædvanligvis med udgangspunkt i 'gængse' kvalitative metoder (Berliner et al., 2005). Men CP behøver ikke udelukkende at anses som en kvalitativ disciplin. Derfor var en spørgeskemaundersøgelse en af de anvendte metoder i dette projekt ${ }^{11}$ (Greenwood \& Levin, 2011; Martí, 2016). Rationalet er, at hvis metoden bruges med respekt for værdierne i CP og i overensstemmelse med deltagernes ønsker og behov, kan den give flere nuancer og skabe relevans for andre projektinteresserede målgrupper ( $\mathrm{fx}$ beslutningstagere m.m.).

Anvendelsen af termen "multi-method" medfører, at metoderne ikke mikses eller integreres, som man fx ser i mixed method-forskning (Brewer $\&$ Hunter, 2006). Brugen af flere metoder indenfor multi-method er derimod begrundet $i$, at enkelte metoder kan supplere hinanden og styrke formodningen om resultaternes relevans (Brewer \& Hunter, 2006).

Når man i CP ofte gør brug af en multi-method-tilgang, er det med en ambition om at fremføre et socialt robust billede og dermed fremme troværdigheden af undersøgelsen. Det illustreres fx ved, at de inddragede metoder i unge, holdspil og medborgerskab er valgt med udgangspunkt $\mathrm{i}$ at kunne generere righoldig og supplerende data $\mathrm{i}$ et komplekst

10 Se mere på: http://www.holdspil.ku.dk/forskning/forskningsprojekter/projekt4/

11 For en argumentation for hvorfor og hvordan, henvises til afhandlingen for projekt unge, holdspil og medborgerskab (Ryom, 2017). 
undersøgelsesmiljø. Således har det været relevant at gøre brug af en række metoder som observation, interviews, fokusgrupper og spørgeskemaer.

For at sikre gennemsigtighed og troværdighed arbejdes der bl.a. i CP metodisk med sigte på stringent og relevant brug af metoder ${ }^{12}$ (Roth \& Bradbury, 2008). Denne ambition betyder, at metoderne ikke skal opleves som rigide eller ufleksible for deltagerne. Dermed fokuseres i høj grad på, hvordan metoder bliver brugt, så de kommer deltagerne til gode og opleves meningsfyldte. Overordnet skal ønsket om at bruge flere metoder også ses i relation til en ambition om, at den genererede viden skal kunne komme deltagerne til gode (Duus et al., 2014).

Som afsluttende kommentar omkring tilgangen CP og metodebrug heri er det en nødvendighed at påpege, at CP som tilgang ikke skal forstås som ringeagtelse for, hvad der kan karakteriseres som mere traditionelle tilgange. Respekt for og påskønnelse af de forskellige paradigmer og tilgange til forskning er nødvendig at have in mente, når en sådan pluralitet (som CP i realiteten repræsenterer) forsøges udført indenfor forskning (Ospina et al., 2008).

\section{Diskussion}

På baggrund af det hidtil præsenterede ønskes det nu at diskutere betydningen af en tilgang som CP indenfor idrætspsykologi. Spørgsmålet er: Hvordan kan denne tilgang give nytte og med hvilke perspektiver. I den forbindelse fremlægges væsentlige erfaringer med tilgangen, der er gjort på baggrund af det præsenterede eksempel. Diskussionen skal komme tættere på, hvilken værdi CP kan tilføre idrætspsykologi.

Det overstående eksempel fra det CP orienterede forskningsprojekt unge, holdspil og medborgerskab tydeliggør, hvordan CP kan bedrives som del af et idrætspsykologisk forløb. Selvom måden at arbejde på

12 Dette er kun et af Roth \& Bradburys (2008) validitetskriterier, som samlet dækker over: a) Hvordan giver projektet værdi, skaber det menneskelig trivsel? b) Engagerer projektet deltagerne, og supporterer det deltagelse og partnerskaber? c) Gør undersøgelsen brug af stringente metoder, som er kulturelt relevante? d) Efterlader projektet infrastruktur, som skaber empowerment for deltagerne, som rækker ud over projektet selv? (egen oversættelse). Disse kriterier har ageret guidelines for sikringen af kvaliteten af hele projektet. 
adskiller sig fra mere traditionelle tilgange, synes resultaterne fra dette studie at påpege en række nye muligheder.

Med tanke på det nærværende projekt, gør det sig især gældende, hvis målgruppen kan karakteriseres som marginaliseret, og/eller nærmiljøet er ressourcesvagt. I sådanne omgivelser synes CP især at komme til sin ret, da selve tilgangen betyder en bekymring om social retfærdighed, inklusion og deltagelse, værdien af diversitet, samarbejde og ressourcer (Kloos et al., 2012). Dertil bør det dog understreges, at et ensidigt fokus på idrætspsykologiske CP-projekter af denne karakter ikke bør forhindre projekter med andet sigte i udsatte boligområder. Det kunne ligeledes være interessant at se CP-studier udført i fx ressourcestærke miljøer, og hvilken betydning de får her.

Baseret på resultaterne af projekt unge, holdspil og medborgerskab (Ryom, 2017) synes projektet at have gavnet både individuelt og socialt/ lokalt. Gennem en bred indvirkning på både individ, grupper og hele miljøet synes $\mathrm{CP}$ at have nogle fordele frem for traditionelle psykologiske interventioner med fokus på den enkelte. Ved at tage udgangspunkt i lokalmiljøet kan et projekt komme flere aktører til gode, og med den rette tilgang kan ændringerne blive bæredygtige, dvs. blivende ændringer i lokalområdet, såfremt lokalmiljøet engageres, og der skabes empowerment.

Med udgangspunkt i dette projekt synes det evident, at man ved hjælp af et fælles tredje (in casu: fodbold og coaching/mentoring) kan opbygge arenaer, som kan påvirke, ændre og styrke lokalmiljøer og aktørerne heri. Her synes særligt fysisk aktivitet og coachingpsykologiske interventioner at skabe en synergi, som er baseret på vores erfaringer med holdsport/ fodbold og gruppecoaching (Ryom et al., 2017). For målgruppen og involverede aktører var det meningsfuldt, og betydningen af deres direkte involvering i projektet var udtalt.

Foruden at udvikle og styrke lokalområdet synes projektet at bidrage til psykosocial udvikling af samtlige deltagere i projektet (Cefei, 2009; Gledhill, Harwood \& Forsdyke, 2017). Herved kan et omfattende socialt projekt få stor betydning for personlig udvikling såsom resiliens/livsduelighed, kropslige kompetencer, motivation og selvopfattelse. Fire faktorer, som psykologisk anses som vigtige i psykosocial udvikling (Gledhill 
et al., 2017). Perspektiverne i en CP-tilgang er således mange og med erfaringen fra dette studie opnåelige. Samtidigt må det påpeges, at tilgangen er særdeles krævende for forskeren ift. en mere traditionel tilgang (mere om dette i et senere afsnit om praktiske implikationer som forsker).

Med erfaringerne fra dette projekt kan følgende fremhæves som særlige kendetegn ved anvendelse af CP (Orford, 2008):

- CP placerer mennesker i deres sociale kontekst

- Magt, empowerment og disempowerment er centrale koncepter i $\mathrm{CP}$

- Praksis i CP betyder, at man samarbejder, hovedsageligt med mennesker i miljøet og med grupper, som synes marginaliserede og disempowered

- CP fordrer brugen af forskellige forsknings- og handlingsrettede metoder.

Ved at bringe det sociale i spil bryder CP med den gængse individfokusering i psykologien, som også er fremtrædende indenfor idrætspsykologien. Dette synes at være en essentiel fordel, når forskning og udviklingsarbejde har marginaliserede eller udfordrede grupperinger i samfundet som målgruppe.

Endvidere er magt og empowerment centrale elementer i CP, hvilket tillægger CP en dybde i kraft af, at CP ikke kun skal forstås som praktiske handlinger og lokale ændringer, men også af større samfundsmæssig betydning. Der opereres således både på mikro- og makroniveau i CP, hvorved forskning af denne karakter berører både 1., 2. og 3. persons perspektiv ${ }^{13}$ (Reason \& Bradbury, 2008).

Praksis i CP omhandler som sagt involvering og samarbejde med fokus på at styrke marginaliserede mennesker eller grupperinger. Derved orienterer CP sig også mod den såkaldte modus 2-viden ${ }^{14}$, der kendetegnes

13 Indenfor aktionsforskning søger man aktivt at arbejde med alle tre perspektiver som et kendetegn ved sådanne projekter.

14 Modus 2-viden skal forstås som det modsatte af modus 1 viden, som groft kan karakteriseres som den traditionelle videnskabelige måde at producere viden på, med klar adskillelse mellem forsker og aftager af viden (Duus et al., 2014). 
ved at være kontekstorienteret, problemfokuseret og tværfaglig (Duus et al., 2014). Dermed har CP også et anvendelsesorienteret fokus, ved at søge løsninger på menneskers virkelige problemer i deres konkrete hverdag. Dette gør CP til ideel samfundsforskning, som giver mere end 'blot' data til forskerne.

CP som tilgang appellerer til en varieret metodebrug som grundlag for empiriindsamling. Det hænger også sammen med en ofte tværvidenskabelig tilgang. Således kan det påpeges at en af styrkerne ved CP er et fokus på metodiske, demokratiske tilgange (Toulmin, 1996), hvor de metodiske valg i højere grad skal samspille med den aktuelle kontekst end samstemmes med en snæver videnskabelig forståelse. Dette kan på den anden side også fremføres som en svaghed. CP-forskere bør derfor være omhyggelige med at sikre en høj grad af gennemsigtighed i deres forskning.

Således ønsker forfatterne bag denne artikel at understrege, at en CP-tilgang er en unik og innovativ tilgang i det idrætspsykologiske felt, men indeholder samtidig markante implikationer for arbejdet som forsker, som i flere henseende kræver en nyorientering i kraft af CP's værdiorienterede tilgang:

1. CP er ikke vardifri forskning, principielt bør det ses som det modsatte, idet det er politisk engageret forskning. $\mathrm{CP}$ fokuserer på idéen om det gode liv og et samfund, hvor fx retten til at blive hørt og udvidelsen af retten til ressourcer og livskvalitet er essentiel (Berliner et al., 2005).

2. CP forsøger at skabe lige adgang til ressourcer, muligheder, rettigheder og fordelingen af magt som helhed. Dette kan gøres ved at skabe samhørighed, fællesskab eller community-følelse til gavn for deltagerne. Eksemplerne er mange, såsom interessegrupper, ritualer, fester eller i vores tilfælde et fælles tredje omkring fodbold og coaching. Rationalet er at arbejde med en proces, hvor der skabes inkluderende fællesskaber, hvori individer har mulighed for aktiv deltagelse. Det centrale tema er mangfoldighed som et konstruktivt inkluderende fællesskab (Berliner et al., 2005).

3. Deltagelse anses som et grundelement for forskning i et CP-perspektiv. Det er i samspillet imellem community, individ og forsker, at 
barrierer for og mulighederne i en given udfordring forhandles og præciseres. Endvidere er det også i dette samspil, at beslutningen omkring et evt. forløb tages (Berliner et al., 2005).

Målet for CP-forskeren er at bidrage til empowerment af lokalmiljøer og deltagere igennem etablering af ligeværdig dialog for alle involverede. Denne forstålse bygger på et princip om at arbejde med respekt for menneskelig forskellighed. Det kan være fx alder, handicap eller socio$ø$ konomisk status. Fundamentet for CP rækker derfor ud til hele miljøet og bør forstås deri (Berliner et al., 2005).

\section{Praktiske implikationer i arbejdet som CP-forsker}

Community-psykologerne Grant, Nelson og Mitchell (2008) præsenterer fem udfordringer, som er nødvendige at være refleksiv omkring i rollen som CP forsker (egen oversættelse og tilpasning); opbygning af relation, anerkendelse og deling af magt, tilskyndelse til deltagelse, gennemførelse af forandringer og etablering af troverdige beretninger. Disse fem udfordringer har også været centrale at bearbejde og overveje i det føromtalte projekt. Til trods for italesættelsen som udfordringer bør de samtidig forstås som potentialet $\mathrm{i}$ arbejdet med CP.

\section{Opbygning af relation}

Den relation, der opstår i et CP-projekt, er af afgørende betydning for den mulige succes for et handlingsrettet forløb. I denne forbindelse er det vigtigt at fremhæve, at forskeren ofte vil være en outsider, som skal opbygge tillid i et lokalmiljø. Som forsker må man derfor lægge megen vægt på opbygning af relationer til og imellem de involverede. Det er relationerne, som sikrer de gode CP-projekter og samtidig styrker bæredygtigheden i denne forskningsform.

\section{Anerkendelse og deling af magt}

Magt er et af de centrale temaer i CP med særligt sigte på at påpege uligheder i samfundet. Forskeren vil som oftest have en relativt stor magt 
ift. deltagerne, hvilket kan medføre en mulighed for kontrol af deltager/ forløb. Dette aspekt bør forsker(e) og de involverede italesætte og reflektere over. At opgive kontrol og stræbe efter lighed i magt er således en væsentlig udfordring, som kan være kompliceret og udfordrende for forskeren. Som tilfældet var med opbygning af relationer, er det vigtigt i CP, at forskeren er reflekteret over denne magt og måder, hvorpå man kan dele magt.

\section{Tilskyndelse til deltagelse}

Deltagelse vil altid variere i et CP-projekt, og det er vigtigt for forskeren at være bevidst om, at forskellige grader af involvering vil kendetegne et projekt. Så til trods for ofte entusiastiske forskere mht. deltagelse fordres det at være refleksiv og bevidst om, at deltagelse ikke forankres i ublu forventninger fra forskerens side. Man bør således søge at forstå deltagernes interesse og ønske om at deltage, imens man søger at gøre deltagelse mulig på varierede måder, så flest mulige kan deltage ( $\mathrm{fx}$ med varieret metodebrug). Derfor er det også vigtigt at skabe en åben diskussion om deltagernes behov frem for at fremføre egen agenda som forsker. Grant og kollegerne (2008) præsenterede flere barrierer ift. deltagelsen, som er væsentlige at overveje: tidsforbrug, økonomi, sprogbarriere, intimidering og rovdrift på enkelte deltagere ledende til udbrondthed.

\section{Gennemførelse af forandringer}

$\mathrm{Da} \mathrm{CP}$ kendetegnes ved handling og dermed et ønske om at skabe forandringer, er det indenfor CP essentielt at forholde sig til og være reflekteret omkring dette. At gennemføre ændringer i et lokalmiljø er ikke nogen simpel opgave, hvilket bør tydeliggøres for alle involverede. Ligeledes vil sådanne forandringer ofte være en langsom proces, hvorfor det er de små succeser, som bør fejres, frem for en forventning om drastiske ændringer. Derfor må det også påpeges, at bæredygtighed er det centrale punkt i denne type af forskning, hvorved et projekt bør kunne leve videre efter eventuel afsluttende forskningsrapportering. 


\section{Etablering af troværdige beretninger}

Der findes kritiske røster, som fremhæver, at handlingsrettet forskning (og dermed CP), ikke er egentlig forskning, men snarere community-udvikling og praksis. En sådan kritik synes misforstået, da et handlingsrettet perspektiv i praksis er forskning, som leder til community-udvikling. Men for at imødekomme ovennævnte kritik, misforståelsen til trods, er det nødvendigt ikke kun at skele til de potentielle forandringer, men også skabe troværdige beretninger om forskningen. En sådan troværdighed må forstås med udgangspunkt i deltagernes oplevelser, hvorfor validiteten af et sådant forskningsprojekt med fordel kan bindes op på en ambition om at skabe social robust viden (Nielsen \& Nielsen, 2015).

\section{Konklusion}

I dette kapitel har vi præsenteret potentialet $\mathrm{i}$ en handlingsrettet forskningstilgang i form af community psykologi i et idrætspsykologisk projekt i København, Danmark. Denne unikke tilgang gav mulighed for en anden måde at arbejde med psykologi på indenfor fysisk aktivitet og sundhed. Tilgangen hjalp deltagerne til at udvikle fysisk og mentalt sunde liv på egne præmisser og skabte øget deltagelse i og glæde ved fysisk aktivitet og skolegang. Den involverende og medbestemmende tilgang syntes befordrende for deltagerne og fik stor betydning for deres oplevelse af projektet. Dette til trods for at deltagerne i dette studie ofte oplevedes som modborgere i samfundet af det omkringliggende samfund, frem for medborgere. Igennem studiet og tilgangen lykkedes det at skabe social og personlig udvikling samt at arbejde med medborgerskab på måder, der gav mening for deltagerne. På baggrund af erfaringer fra dette studie synes CP at være en spændende og anderledes tilgang indenfor idrætspsykologi, især når målgruppen er marginaliserede eller udsatte grupper.

\section{Tak til}

Dybfølt tak til skoleledelse, lærere, pædagoger og elever på skolen for at byde os velkommen og inkludere os i deres fællesskab og hverdag. Tak til 
coaches/mentorer, fodboldtrænere, fodboldklubben, kollegaer, fonde og lokalmiljø. Uden jeres åbenhed og deltagelse kunne vi aldrig have gennemført projektet.

\section{Litteraturliste}

Agergaard, S. (2015). Evalueringsforskning. I Thing, L.F., \& Ottesen, L.S., Metoder $i$ idrots- og fysioterapiforskning. Munksgaard, 2. udgave.

Bauman, Z. (2003). Foellesskab. Hans Reitzels forlag.

Beck, U. (2002). Risikosamfundet - På vej imod en ny modernitet. Hans Reitzels Forlag.

Berliner, P., Høffding, M.R., \& Hakesberg, S. (2005). At fare vild-sammen. Introduktion til community psykologi. Pozkal, Polen: Frydenlund.

Brewer, J. \& Hunter, A. (2006). The Multimethod Approach and Its Promise. I Brewer, J. \& Hunter, A., Foundations of Multimethod Research. Thousand Oaks, CA: SAGE Publications: 2-16.

Bronfenbrenner, U. \& Morris, P.A. (2006). The Bioecological Model of Human Development

(793-828). I: Lerner, R.M. (Ed.) Handbook of child psychology sixth edition. Vol 1

Theoretical models of human development. NJ: John Wiley and Sons.

Brydon-Miller, M., Greenwood, D., \& Maguire, P. (2003). Why Action Research? Action Research, 1(1): 9-28.

Cargo, M., Grams, G.D., Ottoson, J.M., Ward, P., \& Green, L.W. (2003).

Empowerment as fostering positive youth development and citizenship. American Journal of Health Behavior, 27(1), S66-S79.

Danish, S., Taylor, T., Hodge, K., \& Heke, I. (2004). Enhancing youth development through sport. World Leisure Journal, 46(3): 38-49.

Danmarks Statistik (2015). Uligheden i indkomst vokser. Tilgået d. 4.5.2018: https:// www.dst.dk/da/Statistik/nyt/NytHtml? cid=20653

Duus, G., Husted, M., Kildedal, K., Laursen, E. \& Tofteng, D. (2014). Aktions Forskning - En Grundbog. Frederiksberg: Samfundslitteratur.

Cefai, C. (2009). Frem elevens livsduelighed. Viborg: Dansk Psykologisk Forlag.

Geertz, C. (1973). The interpretation of Culture. New York: Basic Books.

Giddens, A. (1997). Modernitet og selvidentitet - Selvet og samfundet under senmoderniteten. Hans Reitzels Forlag.

Gledhill, A., Harwood, C., \& Forsdyke, D. (2017). Psychosocial factors associated with talent development in football: A systematic review. Psychology of Sport and Exercise, 31, 93-112.

Gould, D. \& Carson, S. (2008). Life skills development through sport: Current status and future directions. International Review of Sport and Exercise Psychology, 1(1): $58-78$. 
Grant, J., Nelson, G., \& Mitchell, T. (2008). Negotiating the Challenges of Participatory Action Research: Relationships, Power, Participation, Change and Credibility (589-601). I P. Reason, \& H. Bradbury. The SAGE Handbook of Action Reasearch - Participative Inquiry and Practice. UK: SAGE..

Greenwood, D.J. \& Levin, M. (2011). Introduction to Action Research. Thousand Oaks, CA: SAGE.

Hardcastle, S.J., Glassey, R.S., Hagger, M., \& Tye, M. (2015). Exploring the perceived effectiveness of a life skills development program for high-performance athletes. Psychology of Sport and Exercise, 16(3), 139-149.

Henriksen, K., Larsen, C.H., Storm, L.K., \& Ryom, K. (2014). Sport psychology interventions with young athletes: The perspective of the sport psychology practitioner. Journal of Clinical Sport Psychology, 8(3), 245-26o.

Heron, J. \& Reason, P. (1997). A Participatory Inquiry Paradigm. Qualitative Inquiry, 3(3), 274-294.

Husen, M. (1996). Det foelles tredje. from http://michaelhusen.dk/det-faelles-tredje/. Hussain, M. (2014). Muslims in Copenhagen: Social Cohesion or a Parallel Society? Results from an Empirical Survey 2008-09. Tidsskrift for Islamforskning, 8(1), 106-136.

Kloos, B., Hill, J., Thomas, E., Wandersmann, A., Elias, M.J., \& Dalton, J.H. (2012). Community Psychology. Linking Individuals and Communities. Wadsworth: Cengage Learning

Kvale, S. \& Brinkmann, S. (2009). InterView. Introduktion til et håndverk. Latvia: Hans Reitzels Forlag.

Martí, J. (2016). Measuring in action research: Four ways of integrating quantitative methods in participatory dynamics. Action Research, 14(2), 168-183.

Nielsen, K.A. (2004). Aktionsforskningens videnskabsteori. I Fuglsang, L. \& Olsen, P.B. (red.), Videnskabsteori i Samfundsvidenskaberne: På tvors af fagkulturer og paradigmer. Frederiksberg: Roskilde Universitetsforlag. 2: 517-547.

Nielsen, B.S. \& Nielsen, K.A. (2015). Aktionsforskning. Latvia: Hans Reitzels Forlag.

Ospina, S., Dodge, J., Foldy, E.G., \& Hofmann-Pinilla, A. (2008). Taking the Action Turn: Lessons from Bringing Participation. I Reason, P. \& Bradbury, H. SAGE Handbook of Action Reseach - Participative Inquiry. UK: SAGE.

Orford, J. (2008). Community Psychology. Challenges, Controversies and Emerging Consensus. West Sussex, England: Wiley.

Putnam, R.D. (200o). Bowling Alone - The Collapse and Revival of American Community. New York: Simon \& Schuster.

Reason, P., \& Bradbury, H. (2008). The SAGE Handbook of Action Research: Participative Inquiry and Practice. London: SAGE.

Rose, N. (2000). Government and control. The British Journal of Criminology, 40(2), 321-339. 
Roth, G. \& Bradbury, H. (2008). Learning History: An Action Research Practice in Support of Actionable Learning (350-365). I P. Reason, \& H.Bradbury, SAGE Handbook of Action Research - Participative Inquiry and Practice. UK: SAGE:

Ryom, K., Stelter, R., \& Plannthin, L. (2014). Gruppecoaching og inklusion af udsatte drenge i skolen. KvaN - et tidsskrift for loereruddannelsen og folkeskolen, 34(100), 78-90.

Ryom, K., Andersen, M.M., \& Stelter, R. (2017). Coaching at-risk youth in a school within a socially challenging environment, Improving Schools 2o(2), 143-160.

Ryom, K. (2017). Unge, holdspil og medborgerskab - Det dårlige selskab? Et lokalt aktionsforskningsprojekt på Ydre Nørrebro. Ph.D. afhandling.

Schmidt, G. (2011). 'Grounded' politics: Manifesting Muslim identity as a political factor and localized identity in Copenhagen. Ethnicities, 12, 603-622.

Schmidt, G. (2016). Space, politics and past-present diversities in a Copenhagen neighbourhood. Identities: Global Studies in Culture and Power, 23, 51-65.

Somekh, B. (2008). Action Research. I L.M. Given, The SAGE Encyclopedia of Qualitative Research Methods. SAGE publications.

Henriksen, K. \& Stambulova, N. (2017). Creating optimal environments for talent development: A holistic ecological approach (271-284). I J. Baker, S. Cobley, J. Schorer, \& N. Wattie, (red.). Handbook of Talent Identification and Development in Sport. Routledge.

Spittler, G. (2001). Participant observation as thick participation. Zeitschrift für Etnologie, 126, 1-25.

Spittler, G. (2014). Thick Participation and Beyond. Sociologus, 64(2), 207-230.

Stelter, R. (2014). A guide to third generation coaching: narrative-collaborative theory and practice. Dordrecht: Springer Science+Business Media B.V.

Stelter, R. (2016). Kunsten at dvele i dialogen. Dansk Psykologisk Forlag.

Thorpe, H. (2012). The ethnographic (i)nterview in the sports field: towards a postmodern sensibility (51-78). I K.A. Young, \& M. Bingley, Qualitative Research on Sport and Physical Culture. Emerald.

Thualagant, N. (2011). Kroppens disciplinering gennem idrætten: Foucault, subjektet og det diskursive (96-117). I L.F. Thing \& U. Wagner, Grundbog i idrcetssociologi. København: Munksgaard.

Toulmin, S. (1996). Concluding Methodological Reflections - Élitism and democracy among the sciences (203-225). I S.G. Toulmin, Beyond Theory. John Benjamins Publishing..

Willis, P. (1993). Learning to labour, how working class kids get working class jobs. Aldershot: Ashgate. 



\title{
KAPITTEL 7
}

\section{Hva sier de til seg selv?}

\section{En kvasieksperimentell studie av triatlonutøveres selvsnakk under konkurranse}

\author{
Michael S. Reinboth ${ }^{1 \star}$, Tommy Haugen ${ }^{2}$, Sondre R. Solheim ${ }^{2} \&$ \\ Rune Høigaard ${ }^{2}$
}

${ }^{1}$ Universitetet i Sørøst-Norge. Institutt for friluftsliv, idrett og kroppsøving, Fakultet for humaniora, idrett og utdanningsvitenskap; ${ }^{2}$ Universitetet i Agder, Fakultet for helse- og idrettsvitenskap

\begin{abstract}
Sammendrag: Hensikten med studien var å undersøke hva elitetriatleter sier til seg selv (selvsnakk, SS) under en konkurranse. Deretter ønsket vi å undersøke om det var forskjell og eventuelle endringer i innholdet i og frekvensen av SS hos eliteutøvere versus klubbutøvere under de ulike idrettsgrenene i konkurranse. Totalt deltok tjue triatleter i studien: ti landslagsutøvere og ti klubbutøvere. Konkurransen besto av en innendørs triatlon (750 m svømming i basseng, $20 \mathrm{~km}$ sykling på ergometersykkel og $5 \mathrm{~km}$ løp på tredemølle). For å kunne kartlegge SS under konkurransen besvarte deltakerne en norsk versjon av Automatic Self-Talk Questionnaire for Sports (ASTQS). ASTQS består av fire positive SS-kategorier: opp-psyking, instruksjoner, tillit og angstkontroll, og tre negative SS-kategorier: bekymring, mental frakopling, somatisk tretthet, samt en kategori benevnt som irrelevant SS. Resultatene viste at alle utøverne rapporterte mer positiv SS enn negativ SS under konkurranse. Videre rapporterte eliteutøverne signifikant oftere enn klubbutøvere utsagn i SS-kategorien tillit under svømmingen. Funnene tydet også på at eliteutøverne i større grad enn klubbutøverne opprettholdt positiv SS under den siste delen av konkurransen (løp). Tendensen var motsatt for negativ SS, der eliteutøverne rapporterte mindre negativ SS enn det klubbutøverne gjorde mot slutten av konkurransen / under siste distanse.
\end{abstract}

Nøkkelord: indre monolog, triatlon, landslag, klubbutøvere

\begin{abstract}
The purpose of this study was to examine the self-talk of elite triathletes during a competition. Furthermore, we wanted to investigate possible differences in content and frequency in self-talk during a triathlon competition among elite and club triathletes. Participants were ten members of the Norwegian triathlon national team as well as ten triathletes competing at Norwegian club level. The competition consisted of an indoor sprint-distance
\end{abstract}

\footnotetext{
${ }^{*}$ Korresponderende forfatter: Michael S. Reinboth, Institutt for friluftsliv, idrett og kroppsøving, Fakultet for humaniora, idrett og utdanningsvitenskap, Universitetet i Sørøst-Norge, Postboks 23, 3833 Bø i Telemark, tlf. 35952777 Michael.Reinboth@usn.no

Sitering av denne artikkelen: Reinboth, M.S., Haugen, T., Solheim, S.R. \& Høigaard, R. (2018). Hva sier de til seg selv? En kvasieksperimentell studie av elite- og klubbutøveres indre samtale under en triatlonkonkurranse. I T. Haugen \& R. Høigaard (red). Trender i idrettspsykologisk forskning i Skandinavia (Kap. 7, s. 145-161). Oslo: Cappelen Damm Akademisk. DOI: https://doi.org/10.23865/noasp.39.ch7 Lisens CC-BY 4.0
} 
triathlon (a $750 \mathrm{~m}$ pool swim leg, a $20 \mathrm{~km}$ ergometer cycling leg, and a $5 \mathrm{~km}$ treadmill run leg). Self-talk content and frequency were measured using a Norwegian version of the Automatic Self-Talk Questionnaire for Sports (ASTQS). Overall, results showed that all athletes reported more positive than negative self-talk during competition. Moreover, elite athletes reported more confidence-inducing self-talk compared to the club level athletes during the swim. The findings also indicated that elite athletes were more able than club athletes to maintain higher levels of positive self-talk during the latter stages of the competition ( $5 \mathrm{~km}$ run). This tendency was reversed regarding negative self-talk. Elite athletes reported less negative self-talk compared to club level athletes towards the end of the competition.

Keywords: self-talk, triathlon, national team, club athletes

\section{Introduksjon}

Triatlon er kategorisert som en multisport, og består av idrettsgrenene svømming, sykling og løping. Konkurransene har alltid fellesstart og går kontinuerlig fra starten av svømmingen til man er ferdig med løpingen. Tiden man bruker i skiftesonene mellom overgang fra svømming til sykling og fra sykling til løping, teller med i den totale tiden. De siste fem årene har Norge som triatlonnasjon vokst, og landslaget har flere medaljer og topprestasjoner fra EM og VM både hos junior-, U23- og seniorutøvere (http://triathlon.no/).

$\AA ̊$ gjennomføre en triatlondistanse gir som regel rikelig med tid for utøvere til å snakke til seg selv, enten det er ved å uttrykke følelser, stille spørsmål til seg selv eller ved å gi selv-instruksjoner. Innenfor idrett er det å snakke til seg selv en av de mest brukte og kanskje mest effektive psykologiske teknikkene for å øke eller opprettholde prestasjonen samt regulere ulike psykologiske tilstander - som for eksempel selvtillit, spenningsnivå og stemning (Shannon, Gentner, Patel, \& Muccio, 2012; Tod, Hardy, \& Oliver, 2011; Van Raalte, Vincent, \& Brewer, 2016). Det å snakke eller gi instruksjoner til seg selv er i litteraturen omtalt med ulike termer, som for eksempel indre samtale eller stemme, indre monolog eller dialog, automatiske tanker, selvinstruksjon, verbal tenkning og visualisering med lyder (Theodorakis, Hatzigeorgiadis, \& Zourbanos, 2012; Van Raalte et al., 2016). Utfordringen ved å benevne og beskrive «det å snakke til seg selv» på ulike måter er at det kan bli uklart hva som faktisk legges i begrepet. I denne studien tar vi utgangspunkt i det engelske begrepet «self-talk», som i den videre fremstillingen på norsk blir benevnt som «selvsnakk» (SS). Van Raalte et al. (2016, s.141) definerer fenomenet som 
«the syntactically recognizable articulation of an internal position that can be expressed internally or out loud, where the sender of the message is also the intended receiver». At fenomenet er syntaktisk gjenkjennbart, gjør at en ekskluderer verbaliseringer som frustrerte skrik (f.eks. «Ahhh») samt former for tankevirksomhet som ikke er basert på «formelt språk» (mentale bilder, tankeflyt, fornemmelser o.l.). I litteraturen kategoriseres SS på ulike måter. Hardy (2006) knytter det for eksempel til hvilken funksjon det har, og skiller mellom instruksjon-SS og motivasjon-SS, og hvordan de påvirker konsentrasjon, fokusering, selvtillit, regulering av innsats, kontroll over tanker og følelser samt automatisk utførelse av innlærte handlinger (Hardy, Gammage, \& Hall, 2001; Tod et al., 2011). Når det gjelder bruk av SS for instruksjon og motivasjon, finnes det forskning som støtter opp under en såkalt «matching-hypotese» som antar at instruerende SS er mer effektivt ved finmotoriske oppgaver, og at bruk av motiverende SS er bedre for å prestere bra på oppgaver som er av grovmotorisk art (Galanis, Hatzigeorgiadis, Zourbanos, \& Theodorakis, 2016). Samtidig viser en systematisk gjennomgang av 47 SS-studier (Tod et al., 2011) at både instruerende og motiverende SS hadde en positiv effekt på prestasjon ved grovmotoriske oppgaver. I triatlon, som kan sies å være en utpreget grovmotorisk aktivitet, vil en i så måte kunne anta å dra fordel av både instruerende og motiverende SS.

En annen, og mye benyttet kategorisering, er positiv og negativ SS (Hardy, Oliver \& Tod, 2009; Zourbanos, Hatzigeorgiadis, Chroni, Theodorakis, \& Papaioannou, 2009). Positiv SS er utsagn som har et positivt eller oppmuntrende innhold (f.eks. «Dette klarer jeg» eller «Ja»). Negativ SS innebærer uttalelser som har et negativt innhold og som kan reflektere sinne, frustrasjon eller motløshet (f.eks. «Jeg tar feil igjen» eller «Jeg er for treg»). Det er likevel viktig å påpeke at SS med negativ ordlyd i noen tilfeller antas å ha en positiv effekt på for eksempel motivasjon, mens positive utsagn også kan oppleves som distraherende og være med på å redusere idrettslig prestasjon (Van Raalte, Morrey, Brewer, \& Cornelius, 2015). Det som er avgjørende, er hvilken betydning eller mening SS har for utøveren. Flere forskere fremhever også betydningen av å skille mellom innholdet $\mathrm{i}$ SS og hva som er konsekvensen av det (Hatzigeorgiadis, Galanis, Zourbanos, \& Theodorakis, 2014; Theodorakis et al., 2012). Andre typer SS som 
ikke direkte kan kategoriseres som positive eller negative, er for eksempel assosiativ SS og dissosiativ SS. Det første refererer til at man fokuserer på kroppslige opplevelser (f.eks. «Nå binder jeg meg i overkroppen», eller «Jeg kjenner antydning til krampe i låra»), og den siste kategorien inkluderer irrelevante utsagn (repeterende mantraer) som å telle baklengs eller synge, men også at en for eksempel ikke vil bryte konkurransen (Van Raalte et al., 2016).

$\AA ̊$ undersøke utøveres SS er utfordrende, spesielt hvis en ønsker å kartlegge hva de sier til seg selv under selve treningen eller konkurransen. Ifølge Hatzigeorgiadis et al. (2014) kan en ikke måle SS objektivt fordi en må involvere utøveren og er avhengig av vedkommendes selvrapportering. Innenfor idrettspsykologien er de mest benyttede strategier og teknikker for å kartlegge SS-intervju «tenk høyt-teknikk» og spørreskjema hvor utøveren rapporterer retrospektivt (Zourbanos et al., 2009). Når det gjelder bruk av spørreskjema, er det to ulike typer instrumenter som er blitt utviklet. Den første typen fokuserer på bruken av og formålet med SS. For eksempel har Hardy, Hall og Hardy (2005) utviklet «The Self-Talk Use Questionnaire» som utforsker fire ulike dimensjoner (hvor, når, hva og hvorfor) knyttet til SS. Den andre tilnærmingen fokuserer mer på innholdet og strukturen i SS (Hatzigeorgiadis et al., 2014; Theodorakis et al., 2012). Når det gjelder innhold og struktur i SS, har Zourbanos et al. (2009) utviklet «Automatic Self-Talk Questionnaire for Sports» (ASTQS), hvor de identifiserer åtte ulike SS-komponenter i tre ulike kategorier: Positiv SS består av fire komponenter (opp-psyking, instruksjoner, tillit, angstkontroll), og negativ SS består av tre komponenter (bekymring, mental frakopling, somatisk tretthet). Den siste komponenten består av én kategori, irrelevant SS.

Generelt viser forskningen at SS har en positiv effekt på prestasjon innenfor en rekke idretter (for en oversikt, se Hatzigeorgiadis, Zourbanos, Galanis, \& Theodorakis, 2011; Tod et al., 2011). Samtidig påpeker Van Raalte et al. (2015) at majoriteten av forskning på SS er gjennomført i idretter som krever finmotoriske ferdigheter, og som er av kort varighet. Ifølge Van Raalte et al. (2015) vil utøvere i utholdenhetsidretter som varer relativt lenge, ha mer tid til SS, og sannsynligvis vil både bruk og opplevelse av SS være forskjellig fra det man ser hos utøvere som 
har kortere konkurransetid. I tillegg viser forskning at idrettsekspertise (elite- vs. mosjonsutøvere) også innvirker på typen SS som benyttes: I en studie fra Van Raalte et al. (2015) ble maratonløpere som benyttet SS i konkurranser, spurt om å komme med eksempler på hva de sa til seg selv. Resultatene viste at eliteløperne i større grad enn mosjonistene rapporterte SS som fokuserte på kroppen, løpssteg og teknikk (46\% av eliteløperne mot $18 \%$ av mosjonistene). Positivt motiverende SS ble også relativt hyppig benyttet av både eliteutøvere (43\%) og mosjonister (31\%). Videre viste studien at mosjonistene i større grad enn eliteutøverne brukte SS for å flytte oppmerksomheten bort fra selve maratonløpingen. En studie på ikke-profesjonelle maratonløpere (Schüler \& Langens, 2007) undersøkte de negative konsekvensene når løperne møtte «veggen» etter rundt $30 \mathrm{~km}$ under et maratonløp. Løpere som opplevde store utfordringer ved $30 \mathrm{~km}$, men som brukte SS for å takle dette, presterte bedre enn de som ikke brukte SS. Tilsvarende, i en studie på ultratriatleter (Baker, Côté, \& Deakin, 2005) hvor de undersøkte utøverens kognisjon under konkurranse, rapporterte eliteutøvere mer tanker knyttet til prestasjonsutførelse enn ikke-eksperter, som igjen rapporterte flere passive tanker (f.eks. følelse av nervøsitet, spenning eller forventning). Utøverens kognisjon under konkurranse ble undersøkt ved hjelp av en videomontasje fra en konkurranse de hadde deltatt i. Formålet med denne videomontasjen var å hjelpe utøverne med tilbakekalling av kognitiv informasjon.

Selv om de tidligere nevnte studiene undersøker sammenhengen mellom SS knyttet til konkurranse og prestasjon, ble rapportering av SS gjennomført enten i forkant eller i etterkant av konkurransen. Tod et al. (2011) og Hatzigeorgiadis et al. (2011) hevder derfor at en viktig begrensning $i$ forskningslitteraturen er mangelen på studier som undersøker eliteutøveres SS under selve konkurransen.

\section{Studiens forskningsspørsmål}

Som redegjort for innledningsvis er det grunnlag for å hevde at det er utført relativt lite forskning på utøveres SS innen utholdenhetsidretter (Van Raalte et al., 2015). Det er heller ikke, som vi vet om, gjennomført studier 
av SS (innhold og frekvens) under konkurranse hos utøvere på europa- og verdensnivå i triatlon. Studien ønsket av den grunn å få svar på følgende:

1. Hva kjennetegner triatleters SS (innhold og frekvens) under en triatlonkonkurranse?

Basert på forskningsfunn fra Baker et al. (2005) og Van Raalte et al. (2015) ønsket vi i tillegg å undersøke

2. likheter og eventuelle forskjeller i SS (innhold og frekvens) mellom eliteutøvere og klubbutøvere under en triatlonkonkurranse.

\section{Metode}

\section{Deltakere}

Ti utøvere fra det norske triatlonlandslaget (verdenscup, europacup og junior; sju menn og tre kvinner; $M$ alder $=17.9$; $S D=1.79)$ og ti klubbtriatleter (fem kvinner og fem menn; $M$ alder $=30.4 ; S D=13.55$ ) fra to triatlonklubber i Sør-Norge deltok i studien. Landslagsutøverne trente i gjennomsnitt 16.4 timer $(S D=2.80)$ pr. uke og klubbutøverne 6.2 timer $(S D=2.39)$ pr. uke. Studien ble godkjent av Etiske komité (FEK) ved Fakultetet for helse- og idrettsvitenskap ved Universitetet i Agder (UIA). Inklusjonskriteriene for studien var at deltakerne 1) var medlem av en triatlonklubb / et landslag, 2) hadde deltatt og gjennomført minst én triatlonkonkurranse i løpet av det siste året og 3) var skade- og sykdomsfrie. En av landslagsutøverne sto over løpedelen, da vedkommende hadde pådratt seg et stressbrudd i ankelen (ikke i forbindelse med studien).

\section{Prosedyrer og materiell}

I forkant av studien ble det sendt ut et infoskriv til deltakerne. Der ble de orientert om at de skulle gjennomføre en triatlonkonkurranse samt svare på et kort spørreskjema underveis. På selve testdagen fikk både klubbog landslagsutøverne beskjed om at konkurransen skulle bli omtalt i et tidsskrift om utholdenhetssport (Kondis) samt på nettsidene til Norges 
Triatlonforbund (NTF). I reportasjen ville det bli offentliggjort resultater fra den gjennomførte testen. Dette tiltaket ble utarbeidet i samarbeid med landslagssjefen, slik at testpersonene i større grad skulle kjenne et ønske om og et press til å yte sitt beste. I etterkant av studien ble deltakerne informert om at de hadde blitt misledet, og de fikk ny mulighet til å trekke seg fra studien. Ingen av dem benyttet seg av denne muligheten.

\section{Testprosedyrer}

Konkurransen ble gjennomført på forskjellige dager for de to gruppene. Det vil si at de to testgruppene (elite og klubb) aldri hadde kontakt med hverandre. Selve forsøket var utformet som en konkurranse, der de to gruppene gjennomførte den samme testen. Den besto av en innendørs triatlon på olympisk distanse; $750 \mathrm{~m}$ svømming i basseng, $20 \mathrm{~km}$ sykling på ergometersykkel og $5 \mathrm{~km}$ løp på tredemølle.

\section{Måling av SS}

For å kartlegge deltakernes SS ble en norsk versjon av ASTQS (Zourbanos et al., 2009) benyttet. ASTQS er i forbindelse med denne studien oversatt til norsk, basert på anbefalingene til Kvamme et al. (1998). Under konkurransen besvarte utøveren spørreskjemaet tre ganger: mellom svømming og sykkel, mellom sykkel og løp, og etter løp. For at dette skulle være mulig, ble det lagt inn en kort pause etter hver øvelse. Spørreskjemaet besto av til sammen 40 utsagn som målte fire positive (19 utsagn) og tre negative (17 utsagn) dimensjoner av SS, samt en kategori benevnt som irrelevant SS (4 utsagn). Positiv SS består av kategoriene opp-psyking ( (Gjør ditt beste»), angstkontroll («Slapp av»), tillit («Jeg har tro på meg selv») og instruksjoner («Fokuser på hva du trenger å gjøre akkurat nå»). Negativ SS består av kategoriene bekymring («Jeg kommer til å tape»), mental frakopling («jeg vil gi meg»), somatisk tretthet («I dag føler jeg meg dårlig») og en kategori irrelevant SS («Hva skal jeg gjøre senere i kveld?»). Deltakerne besvarte frekvensen av utsagnene på en fempunktsskala ( $1=$ aldri, 5 = veldig ofte). Tidligere studier (Zourbanos et al., 2009; Zourbanos, Hatzigeorgiadis, Tsiakaras, Chroni, \& Theodorakis, 2010; Zourbanos, Papaioannou, Argyropoulou, \& Hatzigeorgiadis, 2014) har vist at ASTQS har tilfredsstillende validitet og reliabilitet. Alpha-koeffisientene for alle sub-skalaene, med unntak av 
opp-psyking $(\alpha=.57)$, lå mellom .78 og .91 og ble ansett som akseptable basert på Nunallys (1978) kriterium på .70 innenfor det psykologiske fagfeltet. I tillegg til å presentere hver SS-kategori separat, ble de fire positive og de tre negative SS kategoriene slått sammen til annenordenskategorier (positiv SS og negativ SS, se figur 1 og 2). Alpha-koeffisientene for positiv SS var .85, og for negativ SS .90.

Testingen av klubbutøverne ble gjennomført ved Spicheren treningssenter i Kristiansand. Det ble her tatt i bruk et 25 meters basseng, spinningsykler av typen Body Bike Connect og tredemøller av typen LifeFitness 95T. Landslagsutøverne ble testet ved Elixia Røa Bad hvor det ble tatt i bruk et 25 meters basseng, spinningsykler av typen Qicraft bodybike og tredemøller av typen Precor. Konkurransedagen startet med at alle deltakerne fikk hver sin personlige tidtaker. Videre ble det gitt en grundig gjennomgang av løypa for både deltakere og tidtakere. Da dette var gjort, gjennomgikk alle deltakere en 10-15 minutters individuell oppvarming. Da konkurransen var over, ble alle spørreskjemaene samlet inn. Konkurransen med landslagsutøverne ble gjennomgått identisk med testen som ble kjørt på klubbutøverne.

\section{Statistiske analyser}

De statistiske analysene ble gjennomført i SPSS 24.o (SPSS, Chicago, IL, USA). Data ble - på bakgrunn av histogram, Q-Q-plot, skewness og kurtosis - vurdert som tilfredsstillende normalfordelt, og deskriptive data er følgelig presentert som gjennomsnittsverdi $(M)$ og standardavvik $(S D)$. Videre ble det benyttet uavhengige t-tester for å undersøke eventuelle forskjeller mellom de to gruppene (landslag vs. klubb) på de ulike kategoriene av SS. Repeated measures ANOVA (innad i grupper) ble gjennomført ved testing av endring i SS fra idrettsgren til idrettsgren. En $p$-verdi $<.05$ ble for alle analysene betraktet som statistisk signifikant.

\section{Resultat}

Som en manipulasjonssjekk ble alle utøverne før start spurt hvor seriøst de tok sin deltakelse i prosjektet på en fempunktskala fra 1 (lite seriøst) 
til 5 (veldig serøst). En gjennomsnittscore på $M=4.10(S D=0.72)$ tyder på at utøverne tok konkurransen på fullt alvor. Det var ingen forskjell i grad av seriøsitet knyttet til deltakelse mellom klubbutøvere og eliteutøvere. Det var også stor nivåforskjell på de to gruppene i prestasjon, med tanke på samlet gjennomsnittstid i minutter for hele konkurransen (elite $M=64.12, S D=5.90$; klubb $M=83.91, S D=9.12$ ). Gjennomsnittstidene for svømming (elite $M=9.28, S D=.86$; klubb $M=16.22, S D=3.10$ ) sykkel (elite $M=37.82, S D=1.96$; klubb $M=43.28, S D=3.67$ ) og løp (elite $M=17.11$, $S D=3.32$; klubb $M=24.41, S D=3.15)$ var også signifikant forskjellig.

Tabell 1. Deskriptive data for positive kategorier av SS, fordelt på idrettsgren og utøvernivå.

\begin{tabular}{|l|c|c|c|c|c|c|c|c|}
\hline & \multicolumn{2}{|c|}{ Opp-psyking } & \multicolumn{2}{c|}{ Angstkontroll } & \multicolumn{2}{c|}{ Tillit } & \multicolumn{2}{c|}{ Instruksjoner } \\
\hline & Elite & Klubb & Elite & Klubb & Elite & Klubb & Elite & Klubb \\
\hline Svøm & $4.1(0.46)$ & $4.0(0.78)$ & $3.3(0.91)$ & $3.4(0.99)$ & $4.3(0.42)^{\star}$ & $3.5(0.81)$ & $4.2(0.56)$ & $4.0(1.05)$ \\
\hline Sykkel & $4.2(0.48)$ & $4.2(0.60)$ & $2.8(0.93)$ & $2.6(1.47)$ & $3.9(0.81)$ & $3.3(1.21)$ & $4.2(0.65)$ & $3.9(0.91)$ \\
\hline Løp & $4.0(0.53)$ & $4.0(0.83)$ & $3.1(1.11)$ & $2.5(1.57)$ & $3.8(0.95)$ & $3.4(1.35)$ & $4.2(0.58)$ & $3.8(0.91)$ \\
\hline
\end{tabular}

Note. $\mathrm{N}=20$. Verdier oppgitt som gjennomsnitt (standardavvik), *statistisk signifikant forskjell mellom elite og klubb $(p<.05)$

Tabell 2. Deskriptive data for negative kategorier av SS, fordelt på idrettsgren og utøvernivå.

\begin{tabular}{|l|c|c|c|c|c|c|}
\hline & \multicolumn{2}{|c|}{ Bekymring } & \multicolumn{2}{c|}{ Frakopling } & \multicolumn{2}{c|}{ Somatisk tretthet } \\
\hline & Elite & Klubb & Elite & Klubb & Elite & Klubb \\
\hline Svøm & $1.6(0.59)$ & $1.6(0.62$ & $1.2(0.31)$ & $1.2(0.44)$ & $1.5(0.58)^{\mathrm{a}}$ & $1.5(0.49)^{\mathrm{c}}$ \\
\hline Sykkel & $1.7(0.78)$ & $1.7(0.66)$ & $1.6(0.85)$ & $1.7(0.79)$ & $2.3(0.97)^{\mathrm{ab}}$ & $2.3(1.00)^{\mathrm{c}}$ \\
\hline Løp & $1.6(0,58)$ & $1.5(0.81)$ & $1.5(0.61)$ & $1.8(0.99)$ & $1.7(0.90)^{\mathrm{b}}$ & $2.3(1.20)$ \\
\hline
\end{tabular}

Note. $\mathrm{N}=20$. Verdier oppgitt som gjennomsnitt (standardavvik), a-clik bokstav indikerer statistisk signifikant forskjell mellom idrettsgrener $(p<.05)$

Tabell 3. Deskriptive data for irrelevant SS, fordelt på idrettsgren og utøvernivå.

\begin{tabular}{|l|c|c|}
\hline & \multicolumn{2}{|c|}{ Irrelevant SS } \\
\hline & Elite & Klubb \\
\hline Svøm & $1.3(0.42)^{\mathrm{a}}$ & $1.4(0.72)^{\mathrm{b}}$ \\
\hline Sykkel & $1.6(0.51)^{\mathrm{a}}$ & $1.8(0.74)$ \\
\hline Løp & $1.4(0,45)$ & $2.0(1.16)^{\mathrm{b}}$ \\
\hline
\end{tabular}

Note. $\mathrm{N}=20$. Verdier oppgitt som gjennomsnitt (standardavvik), a-blik bokstav indikerer statistisk signifikant forskjell mellom idrettsgrener $(p<.05)$ 
Deskriptive data for alle komponentene av SS er vist i tabell 1-3. Triatletene (både elite- og klubbutøvere) rapporterte statistisk signifikant hyppigere positiv SS sammenlignet med negativ S.S $(p<.01$ for alle idrettsgrener). Verdiene i tabell 1 viser høyere angstkontroll-, tillit- og instruksjons-SS hos eliteutøvere enn hos klubbutøverne, og lavere verdi på bekymring-SS (tabell 2) gjennom hele konkurransen, men disse forskjellene var ikke statistisk signifikante. Det ble funnet en statistisk signifikant forskjell mellom elite- og klubbutøvere på rapportering av tillit-SS under svømmingen (tabell 1): eliteutøvere $(M=4.26, S D=0.42)$; klubbutøverne $(M=3.50, S D=0.81) ; t=(18)=2.63, p<.05$. Når det gjelder irrelevant SS (tabell 3 ), ble det identifisert en signifikant økning fra svømming til sykkel hos eliteutøvere $(p<.01)$, samt en signifikant $ø$ kning fra svømming til løp hos klubbutøvere $(p<.01)$.

Figur 1 og 2 illustrerer utviklingen av positiv SS (figur 1) og negativ SS (figur 2) gjennom konkurransen for henholdsvis elite- og klubbutøvere. Det ble ikke identifisert noen signifikante forskjeller mellom elite- og klubbutøvere. For positiv SS ble det identifisert en statistisk signifikant reduksjon for hele utvalget fra svømming til løp $(p<.05)$. Videre ble det identifisert en signifikant økning i negativ SS fra svømming til sykkel for hele gruppa $(p<.01)$.

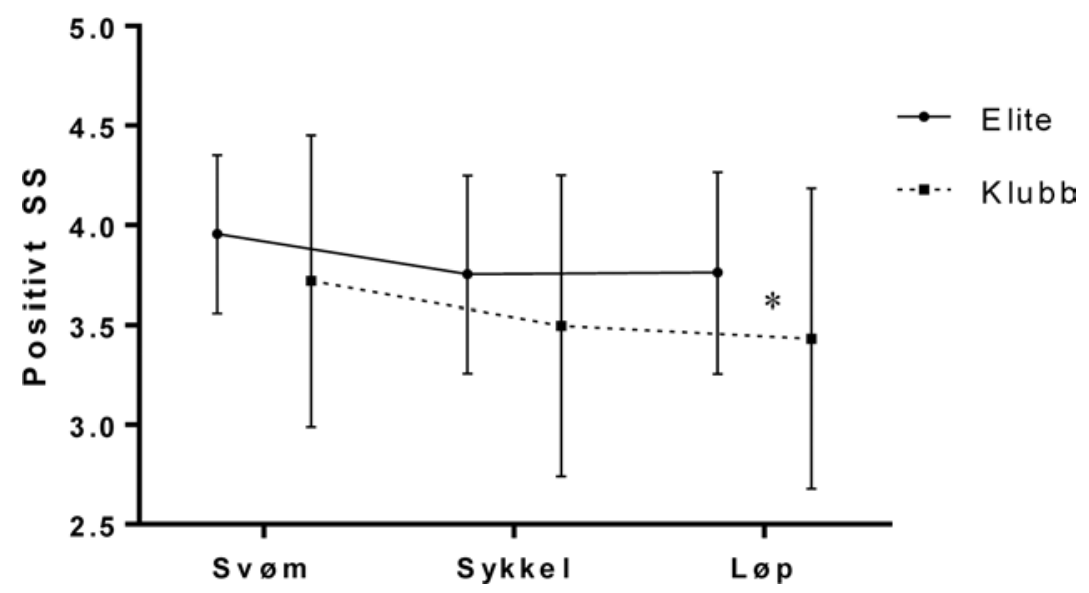

Figur 1. Gjennomsnittscore for positiv SS under svømming, sykkel og løp, på bakgrunn av utøvernivå.

Note. $\mathrm{N}=20$. ${ }^{\star}$ Statistisk signifikant reduksjon for hele utvalget fra svømming til løp. Ingen interaksjonseffekt (idrettsgren $x$ nivå). Ingen gruppeforskjeller ved noe tidspunkt. 


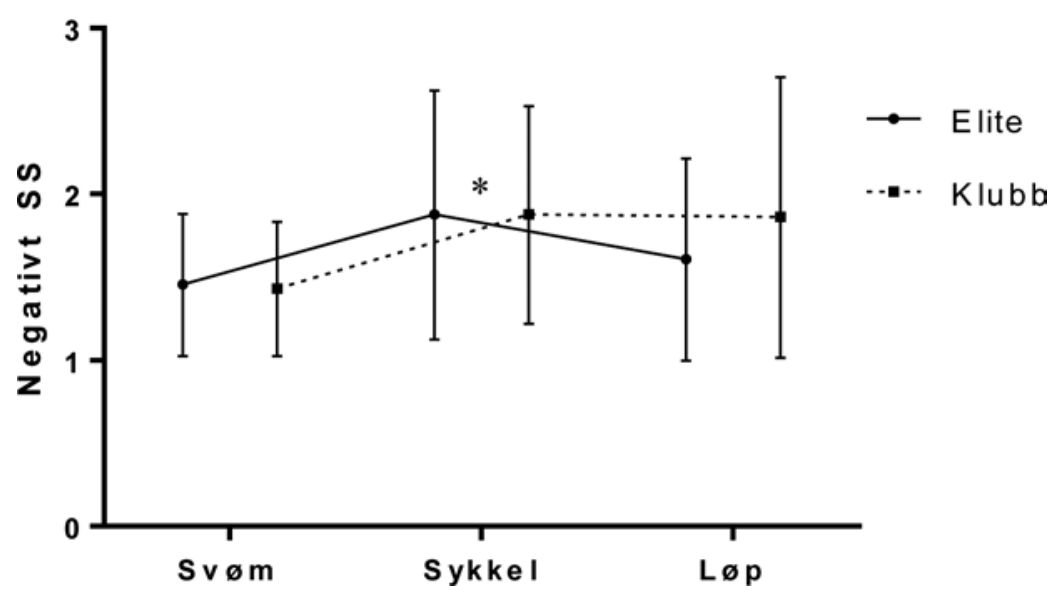

Figur 2. Gjennomsnittscore for negativ SS under svømming, sykkel og løp, på bakgrunn av utøvernivå.

Note. $N=20$. *Statistisk signifikant økning fra svømming til sykkel for hele utvalget. Ingen interaksjonseffekt (idrettsgren $x$ nivå). Ingen gruppeforskjeller ved noe tidspunkt.

Både elite- og klubbutøvere rapporterer generelt lite irrelevant SS under konkurransen (tabell 3). Forekomsten av irrelevant SS øker for eliteutøverne fra første (svømming) til andre (sykkel) idrettsgren, og fra første til siste (løp) for mosjonsutøverne. Til tross for at forekomsten av irrelevant SS ser ut til å bli hyppigere hos klubbutøverne enn hos eliteutøverne mot slutten av konkurransen, var det ingen statistisk signifikante forskjeller mellom gruppene.

\section{Diskusjon}

Formålet med denne studien var å undersøke hvilke typer SS triatleter rapporterer under en triatlonkonkurranse, og i tillegg undersøke hvorvidt det er forskjeller mellom eliteutøveres og klubbutøveres SS. Resultatene viste at det ble rapportert mest positivt motiverende SS (dvs. kategoriene: opp-psyking, angstkontroll, tillit og instruksjon), noe som er i tråd med tidligere studier (Tod et al., 2011; Van Raalte et al., 2015). Resultatene viste videre at utøverne rapporterte relativt lite negativ SS (dvs. kategoriene bekymring, mental frakopling og somatisk tretthet). I hvilken grad utøvernes negative SS er brukt strategisk, er usikkert. Dog indikerer resultatene at negativ SS forekommer, og at den er høyest under 
syklingen og løpingen. Imidlertid er det ikke klart om den relativt høye rapporteringen av positiv SS er det som bidrar til å undertrykke negativ SS. Samtidig kan en merke seg at forskere som Hardy, Hall og Aleksander (2001) og Van Raalte, Brewer, Rivera og Petipas (1994) hevder at negativ SS ikke nødvendigvis har uheldige konsekvenser eller en demotiverende effekt. I en studie på maratonløperne (Van Raalte et al., 2015) benyttet løperne SS med et negativt innhold som en motiverende faktor. Selv om vi med utgangspunkt i denne studien ikke kan avgjøre om negativ SS har en motiverende eller en demotiverende og prestasjonshemmende effekt, er det rimelig å anta at et stort omfang av negativ SS vil kunne prege en utøver og føre til dårligere prestasjoner. Videre studier bør derfor eksplisitt undersøke både omfanget av og innholdet i negativ SS i sammenheng med innsats og prestasjon innenfor ulike idretter og ut fra utøverkarakteristika som for eksempel kjønn, prestasjonsangst, personlighet og motivasjon, for å nevne noen.

Ser vi mer spesifikt på de ulike typene positiv SS (tabell 1), rapporteres kategorien opp-psyking ofte, av både elite- og klubbutøvere. Denne formen for SS er antatt å ha en klar motiverende funksjon (Zourbanos et al., 2009), hvor målet er energimobilisering og maksimering av innsats. Funnene i denne studien viste ingen forskjell i motiverende eller instruerende positiv SS, verken for elite- eller klubbutøvere. Triatlonøvelsene (svømming, sykkel og løp) kan karakteriseres som grovmotoriske, og resultatene støtter dermed ikke den tidligere nevnte «matching-hypotesen» (Galanis et al., 2016), men er i tråd med resultater i studien til Tod et al. (2011). Det ser dermed ut til at man som triatlonutøver må bruke motiverende SS for å holde intensiteten oppe, samtidig som man hele tiden må jobbe med å konsentrere seg om å løse de arbeidsoppgavene som kreves for å kunne utføre hver disiplin så effektivt som mulig (dvs. instruerende SS).

Som en kan se av tabell 1, ble både tillit-SS og instruerende SS rapportert relativt hyppig av alle deltakerne. Til tross for ingen signifikant forskjell i denne studien, tyder resultatene på at elitetriatletene rapporterer noe høyere absolutte verdier av begge disse formene for SS enn klubbtriatletene. Dette ble dokumentert i studien til Baker et al. (2005), hvor ekspert-triatleter (definert som de beste i en konkurranse) rapporterte 
større omfang av «aktive/instruerende tanker» (hvordan respondere i situasjonen nå) og "proaktive tanker» (planlegge neste steg for å forberede seg og optimalisere prestasjonen videre) enn de som presterte dårligere i konkurransen. Noe tilsvarende ble også rapportert i Van Raalte et al. (2015) sin studie på maratonløpere, hvor eliteutøvere benyttet mer assosiativ SS (dvs. fokusering på kroppen, løpssteg, frekvens og holdning) enn det løpere på lavere nivå gjorde. Ifølge Van Raalte et al. (2015) er denne type assosiativ SS ekvivalent til instruerende SS. Når det gjelder instruksjon-SS, handler det om å skape bevissthet og oppmerksomhet knyttet til bevegelser, teknikk og oppgaveløsning. Når eliteutøvere blir intervjuet av media om hvordan de skal klare neste utfordring eller snu en negativ trend, er svaret ofte: «fokusere mer på arbeidsoppgavene». En slik indre instruksjonsfokusering kan dermed være til hjelp for å optimalisere bevegelsesløsninger og arbeidsoppgaver knyttet til konkurransen. Instruksjon-SS kan også knyttes til Zimmermanns (2000) beskrivelse av selvregulering, hvor denne typen SS under konkurransen vil være en strategi for å fokusere på «nøkkel»-elementer knyttet til bevegelsesløsninger og arbeidsoppgaver.

Eliteutøverne rapporterte signifikant mer tillit-SS under svømmingen enn det klubbutøverne gjorde. I forståelsen av denne kategorien kan en ta utgangspunkt i Banduras (1997) mestringstroteori (Galanis et al., 2016). Der fremheves verbal overtalelse som en kilde til mestringstro, og Hardy, Jones og Gould (1996) argumenter for eksempel for at tillit-SS representerer slike egenproduserte verbale overtalelser. Det gir dermed teoretisk grunnlag for å hevde at tillit-SS kan bidra til økt innsats, økt vilje til å holde ut selv om en skulle møte hindringer eller motgang, samt redusert prestasjonsangst. At eliteutøvere oftere enn klubbutøvere rapporterer denne typen SS, kan fremstå som noe overraskende, da en kan anta at eliteutøveres motivasjon og mestringstro er grunnleggende høy og kanskje ikke trenger jevnlig påfyll under for eksempel en konkurranse. Samtidig fremhever Bandura (1997) at mestringstroen ikke er et stabilt trekk, men dynamisk og situasjonspåvirkelig, noe som gjør den sårbar for ytre hendelser og umiddelbare indre opplevelser. Tillit-SS kan derfor anses å være generelt viktig i en konkurranse fordi det kan virke «oppbyggende» og motiverende, og dermed bidra til å vedlikeholde eller øke innsatsen 
og troen på at det kommer til å gå bra. At elitetriatletene rapporterer mer tillit-SS under svømmingen enn det klubbutøverne gjør, er kanskje ikke overraskende, da de førstnevnte er bedre svømmere. Deres svømmetid var i gjennomsnitt nesten dobbelt så god som klubbutøvernes.

Resultatene (tabell 1-3) viser generelt liten variasjon i SS-kategoriene gjennom de ulike delene av konkurransen. Det er imidlertid en tendens til at omfanget av rapportering av kategorien somatisk tretthet øker fra første til andre øvelse. Videre viser resultatene at innslaget av somatisk tretthet opprettholdes under løpsøvelsen for klubbutøverne, men reduseres for eliteutøverne, noe også innslaget av irrelevant SS gjør (tabell 3). $\varnothing$ kningen i somatisk tretthet under syklingen kan oppfattes som naturlig, og kan være et resultat av at utøverne begynner å merke belastningen. Sykkeldelen er også den distansen som er mest tid- og energikrevende. Man bruker vanligvis fire ganger så lang tid på syklingen som på svømmedelen, og dobbelt så lang tid som på løpsdelen. At eliteutøveren rapporterer mindre somatisk tretthet-SS under siste øvelse, kan indikere at de muligens er bedre i stand til å undertrykke eller overstyre både fysiske og mentale tretthetssignaler, eller har mer hensiktsmessig positiv SS. Klubbutøveren, i motsetning til eliteutøveren, har et større innslag av irrelevant SS under løpingen, noe som kan tolkes som at motivasjonen og viljen til å holde på kanskje er redusert, og at oppmerksomheten i større grad er rettet mot «å bli ferdig». Samtidig kan en heller ikke se bort fra at dette brukes som en form for dissossiativ strategi, noe som ble rapportert av mosjonistmaratonløperne i Van Raalte et al. (2015) sin studie, som et bevisst forsøk på å holde ubehaget borte.

\section{Begrensninger og praktiske implikasjoner}

Alle studier må vurderes i lys av deres styrker og svakheter. Den kanskje mest åpenbare svakheten med denne studien er antallet utøvere som ble undersøkt $(\mathrm{N}=20)$. Lav utvalgsstørrelse får ofte betydelige konsekvenser innenfor et kvantitativt paradigme, spesielt knyttet til studiens evne til å generalisere. I tillegg er det verdt å bemerke en tydelig aldersforskjell mellom de relativt unge eliteutøverne og de eldre klubbutøverne. Hvorvidt alder er en faktor med tanke på SS, er per i dag uvisst. En 
annen viktig begrensing ved denne studien er at selv om man spør utøverne om deres SS under konkurransen, er responsen fortsatt å betrakte som retrospektiv. Det kan være vanskelig å huske nøyaktig hva og hvor ofte (under en konkurranse) SS forekommer, selv om det rapporteres umiddelbart etter at en aktivitet i konkurransen er gjennomført. Videre forskning bør derfor vurdere andre metoder som ikke bare baserer seg på retrospektiv innsamling. For eksempel kan en få utøvere til å verbalisere eget SS direkte under aktiviteten og registrere det ved hjelp av en lydopptaker. En slik tilnærming vil kunne gi ny og nyttig informasjon om både frekvens og innhold i SS under en konkurranse. En annen begrensning ved denne studien er at vi ikke kan si noe om intensiteten i SS, altså i hvilken grad det er de enkelte aktivitetene eller belastningen (mer sliten på slutten av konkurransen) som endrer SS, eller hvilken mening og betydning SS har for utøverne personlig. Kvalitative intervju hvor man undersøker utøvers forståelse, mening, bruk og betydning av eget SS, vil kunne være en annen hensiktsmessig tilnærming. Selv om det ble brukt mye tid og krefter på å skape en mest mulig naturtro konkurransesituasjon, er den økologiske validiteten under sykkel og løp naturligvis svekket i og med at utøverne konkurrerte innendørs på spinningsykler og tredemøller, noe som gjorde at den ellers naturlige tilbakemeldingen på hvordan de lå an i forhold til hverandre, uteble. For å øke den økologiske validiteten bør en derfor gjennomføre studier hvor en er i en reell konkurransekontekst.

Triatleters SS under konkurranse bærer i stor grad preg av å være positivt ladet, og fokuserer på motivasjon og instruksjon. Negativ SS rapporteres relativt sett $\mathrm{i}$ liten grad. Resultatene fra denne studien understøttes av tidligere teori og forskning (Tod et al., 2011) og det er derfor grunnlag for å tilråde utøvere å etablere eller vedlikeholde og automatisere positiv SS som en (kognitiv) strategi under konkurranse. Samtidig vil vi presisere at enkelte utøvere motiveres og skjerpes av negativ SS, og derfor bør en nøye vurdere og avklare omfanget av denne samt hvilken effekt den har for den enkelte utøver. Avslutningsvis vil vi hevde at i den grad en som trener vil bidra til å endre eller utvikle en utøvers SS, er det viktig at et slikt arbeid gjøres i nært samarbeid med utøveren selv, for å sikre at innholdet i SS er i tråd med utøvers preferanser. 


\section{Referanser}

Bandura, A. (1997). Self-efficacy: The exercise of control. New York: Freeman.

Baker, J., Côté, J., \& Deakin, J. (2005). Expertise in ultra-endurance triathletes early sport involvement, training structure, and the theory of deliberate practice. Journal of Applied Sport Psychology, 17, 64-78.

Galanis, E., Hatzigeorgiadis, A., Zourbanos, N., \& Theodorakis, Y. (2016). Why SelfTalk Is Effective? Perspectives on Self-Talk Mechanisms in Sport. I: M. Raab, P. Wylleman, R. Seiler, A.M. Elbe \& A. Hatzigeorgiadis (red.), Sport and Exercise Psychology Research. From Theory to Practice (s. 181-200). London: Academic Press Elsevier.

Hardy, J. (2006). Speaking clearly: a critical review of the self-talk literature. Psychology of Sport and Exercise, 7, 81-97.

Hardy, J., Gammage, K., \& Hall, C. (2001). A descriptive study of athlete self-talk. The Sport Psychologist, 15, 306-318.

Hardy, J. Hall, C.R., \& Alexander, M.R. (2001). Exploring self-talk and affective states in sport. Journal of Sport Sciences, 19, 469-475.

Hardy, J., Hall, C.R., \& Hardy, L. (2005). Quantifying athlete self-talk. Journal of Sports Sciences, 23, 905-917.

Hardy, J., Oliver, E., \& Tod, D. (2009). A framework for the study and application of self-talk within sport. I: S.D. Mellalieu \& S. Hanton (red.), Advances in Applied Sport Psychology (s. 37-74). London: Routledge.

Hardy, L. Jones, G., \& Gould, D. (1996). Understanding psychological preparation for sport: Theory and practice of elite performers. Chichester, England: Wiley.

Hatzigeorgiadis, A. \& Biddle, S. (2001). Negative self-talk during sport performance: relationships with pre-competition anxiety and goal-performance discrepancies. Journal of Sport Behaviour, 31, 237-253.

Hatzigeorgiadis, A., Galanis, E., Zourbanos, N., \& Theodorakis, Y. (2014). Self-talk and competitive sport performance. Journal of Applied Sport Psychology, 26, $82-95$.

Hatzigeorgiadis, A., Zourbanos, N., Galanis, E., \& Theodorakis, Y. (2011). Self-talk and sport performance: a meta-analysis. Perspectives on Psychological Science, 6, 348-356.

Kvamme, O.J., Mainz, J., Helin, A., Ribacke, M., Olesen, F., \& Hjortdahl, P. (1998). Interpretation of Questionnaires. A Translation Method Problem, Nordic Medicine, 113, 363-366.

Nunally, J.C. (1978). Psychometric theory. New York: McGraw-Hill.

Schüler, J., \& Langens, T.A. (2007). Psychological crisis in a marathon and the buffering effects of self-verbalizations. Journal of Applied Social Psychology, 37, 2319-2344. 
Shannon, V., Gentner, N., Patel, A., \& Muccio. D. (2012). Striking Gold: Mental Techniques and Preparation Strategies used by Olympic Gold Medalists. Athletic Insight, 4, 1-12.

Theodorakis, Y., Hatzigeorgiadis, A., \& Zourbanos, N . (2012). Cognitions: Self-Talk and Performance. I: S.M. Murphy (red.), The Oxford Handbook of Sport and Performance Psychology, New York, Oxford University Press.

Tod, D., Hardy, J. \& Oliver, E. (2011). Effects of Self-Talk: A Systematic Review. Journal of Sport \& Exercise Psychology, 33, 666-687.

Van Raalte, J.L., Brewer, B.W., Rivera, P.M., \& Petipas, A.J. (1994). The Relationship between Observable Self-Talk and Competitive Junior Tennis Players' Match Performances. Journal of Sport \& Exercise Psychology, 16, 400-415.

Van Raalte, J.L, Vincent, A. \& Brewer, B.W. (2016). Self-talk: Review and sport specific model. Psychology of Sport and Exercise, 22, 139-148.

Van Raalte, J.L., Morrey, R.B., Brewer, B.W., \& Cornelius, A.E. (2015). Self-talk of marathon runners. The Sport Psychologist, 29, 3, 258-260.

Zimmerman, B.J. (200o). Attaining self-regulation: A social cognitive perspective. I: M. Boekaerts, P.R. Pintrich \& M. Zeidner (red.), Handbook of self-regulation (s. 13-39). New York: Academic Press.

Zourbanos, N., Hatzigeorgiadis, A., Chroni, S., Theodorakis, Y., \& Papaioannou, A. (2009). Automatic Self-Talk Questionnaire for Sports (ASTQS): Development and preliminary validation of a measure identifying the structure of athletes' selftalk. The Sport Psychologist, 23, 233-251.

Zourbanos, N., Hatzigeorgiadis, A., Tsiakaras, N., Chroni, S., \& Theodorakis, Y. (2010). A multimethod examination of the relationship between coaching behavior and athletes' inherent self-talk. Journal of Sport and Exercise Psychology, $32,764-85$.

Zourbanos, N., Papaioannou, A., Argyropoulou E., \& Hatzigeorgiadis A. (2014). Achievement goals and self-talk in physical education: The moderating role of perceived competence. Motivation and Emotion, 38, 235-251. 



\title{
KAPITTEL 8
}

\section{Felles mentale modeller i elitelagballspill}

\section{En kvalitativ analyse av spilleres opplevelse av medspillerkunnskap i fotball og håndball}

\author{
Rune Giske ${ }^{1 \star}$, Harald Sylfest Gaard ${ }^{2} \&$ Joar Gjerde ${ }^{1}$ \\ ${ }^{1}$ Universitetet i Stavanger, Institutt for grunnskolelærerutdanning, idrett og \\ spesialpedagogikk ${ }^{2}$ Universitetet i Agder, Fakultet for helse- og idrettsvitenskap
}

\begin{abstract}
Sammendrag: Hensikten med denne undersøkelsen er å utforske medspillerkunnskap (team member knowledge) på elitenivå i lagballspill - teoretisk forankret i felles mentale modeller. Medspillerkunnskapen er teamspesifikk og ikke en type kunnskap som spilleren kan transportere med seg fra lag til lag. Eksisterende forskningslitteratur forteller svært lite om spillernes kunnskap om medspillere og betydningen av denne i spillet. Følgende forskningsspørsmål skal derfor belyses: Hvordan beskriver elitespillere sin kjennskap til medspillere? Hvordan opplever spillerne at kunnskap om medspillere utvikles? Undersøkelsen følger et ideografisk forskningsdesign, og det empiriske materialet består av intervjuer med fire elitespillere i fotball og håndball. Analysen viser at sterke og svake sider, preferanser og prediksjon, kompenserende atferd samt medspillers valør fremstår som tema som utdyper medspillerkunnskapen. Spillernes opplevelse av utvikling av medspillerkunnskap indikerer at dette følger implisitte læringsbaner. Resultatene fra den foreliggende spillerundersøkelsen understøtter betydningen av medspillerkunnskap i håndball og fotball på elitenivå. Trenere og spillere bør derfor reflektere over hvordan den skal fremmes.
\end{abstract}

Nøkkelord: gruppedynamikk, teamkognisjon, koordinering, eliteprestasjoner

\begin{abstract}
The purpose of this inquiry is to explore team member knowledge among elite players in team ballgames - theoretically anchored in shared mental models. Team member knowledge is team specific and not a type of knowledge that players can transport from team to team. Current research literature has only to a limited extent been concerned about team member knowledge and the importance of this in team ball games. The following research questions will therefore be addressed in the present study: How do elite players describe their knowledge of co-players? How do players experience the knowledge development of co-players? The inquiry follows an ideographic research design, and the empirical material consists of interviews with four elite players in football and team handball. The analysis reveals that the following themes elaborate team member knowledge: Strengths and weaknesses, preferences and predictions, compensatory behavior and co-players' value. The players' experience of the development of team member knowledge indicates primarily implicit learning trajectories.
\end{abstract}

*Korresponderende forfatter: Rune Giske, Universitetet i Stavanger, 4036 Stavanger, Rune.giske@uis.no

Sitering av denne artikkelen: Giske, R., Gaard, H.S. \& Gjerde, J. (2018). Felles mentale modeller i elitelagballspill: En kvalitativ analyse av spilleres opplevelse av medspillerkunnskap i fotball og håndball. I T. Haugen \& R. Høigaard (red). Trender i idrettspsykologisk forskning i Skandinavia (Kap. 8, s. 163-185). Oslo: Cappelen Damm Akademisk. DOI: https://doi.org/10.23865/noasp.39.ch8

Lisens CC-BY 4.0 
The findings from the present study support the idea that team member knowledge is an important feature in handball and soccer elite teams. Coaches and players should therefore reflect on how this knowledge should be promoted.

Keywords: group dynamics, team cognition, coordination, elite performance

\section{Introduksjon}

Enkle generaliseringer, som for eksempel «folk er ikke til å stole på», er forestillinger som kan prege vår atferd i møte med nye mennesker. De kalles gjerne mentale modeller, og når de er aktive, påvirker de hvordan vi oppfatter, tolker og handler. Eksperter innenfor ulike områder har som regel hensiktsmessige mentale modeller å arbeide ut ifra, og vi kan forstå dem som relativt spesifikke mentale systemrepresentasjoner av virkeligheten - slik den fortoner seg for personen. Når det gjelder elitelag i ballspill, handler det ikke bare om den enkelte spillers modeller for hvordan laget skal spille, men også om spillerne i laget har utviklet en felles oppfatning av samhandlingen på banen. Å utvikle økt grad av felles forståelse blant medlemmene står sentralt $i$ alle nyere teorier om utvikling av teamprestasjoner (Salas et al., 2015), og i faglitteraturen brukes gjerne begrepet felles mentale modeller om denne delte teamforståelsen (ibid.). Cannon-Bowers, Salas og Converse (1993) definerer felles mentale modeller som:

«knowledge structures held by members of a team which enable them to form accurate explanations and expectations for the task, and, in turn, to coordinate their actions and adapt their behavior to the demands of the task and other team members» (ibid., s. 229).

Ifølge Fiore, Salas og Cannon-Bowers (2001) er grunnlaget i teorien om felles mentale modeller at effektive team sømløst integrerer individuell atferd, slik at den fasiliterer samhandlingen i laget. Slike felles mentale modeller, som all hovedsak er undersøkt i militære team, akuttavdelinger på sykehus og i luftfart (cockpit crew), har vist seg å være betydningsfulle for teamprestasjon (DeChurch \& Mesmer-Magnus, 2010). Det handler om at medlemmene har lik forståelse av det systemet de arbeider innenfor, rammebetingelsene, oppgavene som skal løses, samt styrke og svakheter hos de andre medlemmene. I et lagballspill hjelper en felles mental modell den enkelte spiller til å forstå situasjoner som oppstår, 
slik at vedkommende kan velge et hensiktsmessig handlingsforløp ut fra sin persepsjon av omgivelsene (Reimer, Park, \& Hinsz, 2006; Rouse \& Morris, 1986; Salmon et al., 2008). Slike mentale modeller åpner for visuelle bilder som lar individet forstå, forklare og forutsi lagets tilstand og formål i nåtid og fremtid (Langan-Fox, Wirth, Code, Langfield-Smith, \& Wirth, 2001; Langan-Fox, Anglim, \& Wilson, 2004). Nyere undersøkelser har vist at ballspillgrupper på elitenivå har utviklet hensiktsmessige felles modeller for hvordan både forsvars- og angrepsspillet skal utføres (Giske, Rodahl, \& Høigaard, 2015). Overtallsspill i håndball i angrep er for eksempel ofte basert på kollektive samhandlingsmønster hvor bevegelser og ballbaner er innarbeidet. Slike mønster er et uttrykk for at spillet styres etter felles modeller, der det handler om hvordan laget koordinerer og synkroniserer individuelle handlinger for å løse oppgaver som laget som helhet står overfor. Denne samhandlingskunnskapen gir spilleren mulighet til å forutse spillerhandlingene til de andre i teamet. En veldig enkel del av en felles modell for herrelandslaget i fotball under Egil «Drillo» Olsens første periode som trener var at det skulle slås en lang pasning etter en støttepasning ${ }^{1}$. En slik modell gir en klar instruks eller et handlingsimperativ - om hva du skal gjøre når du mottar en støttepasning, og i tillegg gir den informasjon til medspillerne om hva de kan forvente hvis det blir slått en støttepasning. Denne kunnskapen vil med andre ord gi hele laget et fortrinn overfor en motstander, fordi man vet hva som mest sannsynlig kommer til å skje når det blir slått en støttepasning.

Det er verdt å merke seg at manglende samhandling, med påfølgende mangelfull eller negativ kommunikasjon, kjennetegner lag som opplever en kollektiv kollaps (Apitzsch, 2009).

I både håndball og ishockey har elitelagene felles angrepsmønster som innarbeides under trening, og treneren gir spillerne feedback i lys av synkroniserte handlingsmønster eller felles modeller for samhandling (Giske et al., 2015). Intervjuundersøkelser av elitetrenere i håndball og fotball tyder også på at trening organiseres med tanke på hyppige repetisjoner

1 En støttepasning kan slås bakover eller skrått mot siden, og pasningen slås for å unngå at motstanderen takler og vinner ballen når du er feilvendt, dvs. at spilleren som slår pasningen, har ryggen mot motstanderens mål. 
av samhandlingsmønster (Giske, Gjerde, Gaard, Høigaard, \& Johansen, 2018). En slik praksis beror på en antakelse om at trenere opplever at det er hensiktsmessig at individuelle handlingsvalg automatiseres i et felles, koordinert handlingsmønster.

Et felles samhandlingsmønster skaper en indre ${ }^{2}$ forutsigbarhet i laget med tydelige forventninger til hva som skal skje. Læringen av felles modeller er trolig delvis eksplisitt - fordi det blant annet handler om å forstå egen og andres rolle i spillet. I tillegg foreslår Endsley (1995) at gjentatte erfaringer i et miljø (dvs. spillet på trening og kamp) gjør det mulig å utvikle forventninger om fremtidige hendelser. Endsley (1995) introduserer en umiddelbar mønstergjenkjennende mekanisme som fundamental for å utvikle det han betegner som «situational awareness», eller situasjonsoppfatning. Ifølge Klein (2009) handler dette om at umiddelbart etter at situasjonen er bedømt (situational assessment), vil den mest hensiktsmessige handlingen fremtre uten bevisste overveielser. Dette betyr at å bedømme situasjonen og hente informasjon om hva du skal gjøre, er en del av denne samme prosessen, og utgjør et fenomen som Klein (2009) betegner som «recognition-primed decision-making». Salas med kolleger (1994) argumenterer for at felles mentale modeller gjør det mulig for medspillere å bedømme situasjonen relativt likt, og at dette beror på en felles forståelse av holdepunkter, handlingssekvenser, lagressurser og lik oppfatning av hva som er passende fremgangsmåte for å løse oppgaven. I et eliteteam vil en felles fortolkning av situasjonen, eller en overlapp mellom den enkelte spillers situasjonsoppfatning, bli en nødvendig forutsetning for koordinert samhandling (Endsley, 1995; Salas et al., 1994). Wilson og kolleger (2007) hevder at et effektivt teamsamarbeid er vesentlig når man skal koordinere sine handlinger med andres, og når teammedlemmer er gjensidig avhengige av hverandre. Dette gjelder spesielt når medlemmer av teamet befinner seg i situasjoner som kan betraktes som kaotiske eller tvetydige. Slike situasjoner inntreffer ofte i håndball- og fotballkamper.

2 Det understrekes at felles mentale modeller eller felles koordinerte handlingsmønster i eget lag også kan skape en ytre forutsigbarhet som motstandere kan utnytte. Ofte ønsker elitelag å fremstå som uforutsigbare for motstanderen og mest mulig forutsigbare for egne spillere. 
Cannon-Bowers og Salas (2001) kategoriserer innholdet i det som utgjør teamets felles mentale modeller, i oppgavespesifikk kunnskap, oppgaverelatert kunnskap og medspillerkunnskap (team member knowledge). Delt oppgavespesifikk og oppgaverelatert kunnskap handler om teammedlemmenes kompatible forventninger til oppgaven(e) som skal løses, og skilles fra hverandre med utgangspunkt i hvor generiske (strekker seg over flere oppgaver) eller bestemte forventningene er med tanke på hvordan én kollektiv oppgave skal løses. Deakin og Cobleys (2003) case-studie av volleyballag viste at trenere vektla motstanderspesifikk taktisk instruksjon. Reimer og kolleger (2006) argumenterer for at analyser av motstanderes spill kan skape grunnlaget for en felles oppgavespesifikk modell som kan brukes til å forberede kollektive handlingsmønster mot én spesifikk motstander. Oppgaverelatert kunnskap handler om hvordan laget vanligvis spiller, uavhengig av motstander. Oppstår det f.eks. et numerisk overtall $\mathrm{i}$ angrep (tre angripere mot to forsvarere) løses dette på en bestemt måte, og hvilken motstander man møter, spiller mindre rolle. I hvilken grad trenere tilpasser det kollektive spillet til spesifikke motstandere eller baserer seg mer på generell oppgaverelatert kunnskap, vil variere. Det vil i stor grad bero på trenerens grunnleggende antakelse om hva som er mest effektivt for laget.

Både de oppgavespesifikke og de oppgaverelatert utfordringene som spillerne skal løse underveis i spillet, klargjøres ved å tildele spillerne roller. Skal man oppnå koordinerte og synkroniserte kollektive handlingsmønster, må man etablere gjensidige rolleforventninger knyttet til hvordan oppgavene i spillet skal løses i gitte situasjoner.

Imidlertid er ikke denne oppgavekunnskapen tilstrekkelig for å prestere optimalt, fordi forventningene til medspillernes handlinger også vil bero på kvalitetene til spilleren som fyller rollen. Kunnskap om «team members» - eller medspillerkunnskap - handler om at spillerne også må forstå hverandre, dvs. ha kunnskap om hverandres preferanser, styrker, svakheter og tendenser for å maksimere prestasjonen (Cannon-Bowers \& Salas, 2001). Å etablere en slik felles kunnskap om hverandre fremmer oppgaveutførelsen og hjelper spillerne til å kompensere for hverandre og predikere hverandres handlinger. Med andre ord betyr dette at spillerne blir bedre kjent med hverandre og dermed bedre i stand til å kunne 
tilpasse sin atferd i samsvar med hva de forventer fra medspillere. Det kan for eksempel være at innleggene til spissen må legges høyt fordi hun er sterk i hodedueller, og i håndball vil kunnskapen til en midtback (playmaker) om en skytters behov for høy fart for å kunne skape gode målsjanser være vesentlig for et effektivt samspill. For å forstå samhandling er det derfor vesentlig å ha kunnskap om hvordan spillere tilpasser sine handlinger med utgangspunkt i både kravene i oppgaven(e) og kunnskap om f.eks. medspilleres styrker og svakheter.

Denne medspillerkunnskapen er teamspesifikk, og er ikke noe spilleren umiddelbart kan transportere med seg fra lag til lag. Mer oppgaverelatert kunnskap knyttet til bestemte spillerroller kan spilleren trolig kan ta med seg fra lag til lag, og den handler om at spillere har en mer generell forståelse av hva de skal gjøre i gitte roller (Reimer et al., 2006). Betydningen av kunnskap om medspillere fremheves av den legendariske Manchester United-manageren sir Alex Ferguson: «The essence of a good team is recognising the qualities of each other, and the weaknesses of each other too» (Carson, 2013, s. 115). Medspillerkunnskap har ifølge fotballtreneren (også tidligere Manchester United-manager) Louis van Gaal også en verdi med tanke på utvikling av felles mentale modeller, og han argumenterer for at dette er et viktig grunnlag for resultatutvikling:

In soccer, everything depends on the team aspect. It is therefore important that each player knows what the others can and can't do. You have to discover each other's skills, and this automatically leads to a good mutual understanding, which is the basis for the result (Kormelink \& Seeverens, 1997, s. 3).

Giske med kolleger har i tidligere arbeider fokusert på sammenhengen mellom felles mentale modeller og rolleforventninger (Giske et al., 2015; Giske, Rodahl, Haugen, \& Høigaard, 2017), deriblant i et upublisert arbeid som viser hvordan elitetrenere forsøker å etablere og videreutvikle slike felles mentale modeller i treningsarbeidet (Giske et al., 2018). Den foreliggende forskningslitteraturen forteller imidlertid svært lite om spilleres kjennskap til medspillere og den opplevde betydningen av denne kunnskapen.

Denne artikkelen har derfor til hensikt å utforske medspillerkunnskap på elitenivå i lagballspill, forankret teoretisk i begrepet felles mentale modeller. Følgende forskningsspørsmål skal belyses: 
Hvordan beskriver elitespillere sin kjennskap til medspillere?

Hvordan opplever elitespillere at kunnskap om medspillere utvikles?

\section{Metode}

Elitelag og toppidrett kan studeres som ekstreme caser, og en slik metodisk innfallsvinkel følger vanligvis en ideografisk tilnærming (Robson, 1993). Innenfor idrettspsykologien er dette et anbefalt forskningsperspektiv for å samle unik kunnskap om eliteidrett (Martens, 1987; Vealey, 1994). Vanligvis benytter et ideografisk forskningsdesign kvalitative innfallsvinkler. Ifølge Holloway og Todres (2003) er imidlertid kvalitative tilnærminger svært mangfoldige, komplekse og nyanserte. Braun og Clarke (2006) argumenterer for at kvalitative undersøkelser kan grupperes mer induktivt «bottom up» eller mer teoretisk «top down» - basert på tema eller mønster i datamaterialet. En mer teoribasert tilnærming ble vurdert som mer formålstjenlig, og datamaterialet er tolket utover det semantiske innholdet.

Datakorpus består av intervjuer med fire elitespillere i fotball og håndball, og analysen fokuserer på medspillerkunnskap som er teoretisk forankret i felles mentale modeller. Undersøkelsen er godkjent av NSD, og prosedyrene er i tråd med de etiske standardene til Universitet i Stavanger.

\section{Deltakere}

To fotballspillere fra en eliteklubb ble valgt ut - én eldre og mer erfaren spiller og én yngre spiller. En av spillerne har erfaring fra yngre landslag, og samlet har de i sesongen 2016 og 2017 spilt totalt 81 kamper for laget.

To håndballspillere med lang erfaring ble valgt ut - én kvinnelig og én mannlig spiller. Begge er bakspillere og kan spille både back og midtback. Én av dem har landslagserfaring. Alle de fire spillerne er profilerte på de respektive klubbenes nettsider, og ved å gi flere opplysninger vil identiteten deres kunne avsløres. Av forskningsetiske grunner gis det derfor ikke flere opplysninger om intervjuobjektene. 


\section{Framgangsmåte}

En innledende telefonsamtale ble gjennomført for å avklare om spillerne var villige til å delta. Etter avklaringen ble det avtalt møtetid og møtested med utgangspunkt i respondentenes ønsker. Intervjuene ble gjennomført i komfortable og uforstyrrede omgivelser, og startet med en presentasjon av undersøkelsen, der spillerne ble opplyst om at den handlet om medspillerkunnskap i lagspill på elitenivå. Det ble spurt om tillatelse til å bruke lydbåndopptaker og transkribere intervjuene, noe alle deltakerne stilte seg positive til. De ble også informert om at de som intervjuobjekter ville anonymiseres, og at de kunne få tilgang til å lese den transkriberte versjonen av intervjuet (eventuelt kommentere og justere utsagn) når de måtte ønske det. Videre ble utforskende spørsmål brukt for å studere all ny informasjon knyttet til medspillerkunnskap (Patton, 2002).

\section{Instrument}

Intervjuplanene er forankret i tidligere litteratur som har undersøkt felles mentale modeller knyttet opp mot teamprestasjoner (CannonBowers et al., 1993; Cannon-Bowers \& Bowers, 2006; Eccles \& Tenenbaum, 2004; Giske et al., 2015; Reimer et al., 2006; Ward \& Eccles, 2006). Til tross for denne teoretiske forankringen har undersøkelsen en eksplorerende karakter og inneholder tre overordnede tema: 1) rolleforståelse, 2) medspillerkunnskap og 3) utvikling av medspillerkunnskap. Basert på intervjuplanen ble spillerne eksponert for generelle «prober» eller mer vurderende spørsmål underveis i intervjusamtalene, som for eksempel: «Tenker du styrke og svakheter hos medspiller i rollene, eller mer generelt?»

Tracy (2010) fremhever at god kvalitativ forskning dveler under overflaten for å kunne bringe frem kunnskap som er antatt eller implisitt. For å ivareta dette ble de foreslåtte retningslinjene av Rubin og Rubin (1995) fulgt, dvs. at det ble stilt utforskende spørsmål knyttet til temaene, som for eksempel dette: «Spiller X og spiller Y har samme rolle i laget hvordan opplever du å spille sammen med forskjellige spillere i samme rolle?» Spørsmålene ble stilt for å identifisere, nyansere og beskrive ulike 
aspekter ved medspillerkunnskap som ble løftet frem av respondentene under intervjuet.

\section{Analyse}

I lys av det konseptuelle begrepsapparatet i felles mentale modeller, eller det som Miles, Huberman og Saldana (2014) betegner som «kartet», er «terrenget» medspillerkunnskap utforsket i lys av fire overordnede temaer: sterke og svake sider, preferanser og prediksjon, medspillers valør samt utvikling av medspillerkunnskap. I hvilken grad et tema er betraktet som «keyness», er ifølge Braun og Clark (2006) relatert til om de dekker noe vesentlig ut fra forskningsspørsmålene. Temautvelgelsen er basert på forskergruppens beslutninger knyttet til opplevd relevans overfor de to problemstillingene. En slik praksis synes å være i overensstemmelse med Braun og Clarke (2006), som vektlegger den aktive rollen forskeren spiller med tanke på å identifisere mønster/tema, og selektere hvilke som er mest relevante å rapportere. I første ledd ble en kvalitativ innholdsanalyse (Morgan, 1993) gjennomført ved at materialet ble hørt flere ganger og sentrale utsagn transkribert.

Et mer teoretisk eller analytisk forskningsfokus vil som oftest ikke gi så omfangsrike beskrivelser, og analysen vil gjerne være mer detaljert på noen aspekter ved dataene (Braun \& Clark, 2006). Dette er et forhold som forklarer lengden på de fire intervjuene, som varte mellom 35 og 60 minutter.

\section{Resultater og diskusjon}

Hensikten med denne undersøkelsen var å utforske medspillerkunnskap i lys av begrepet felles mentale modeller. Ifølge Cannon-Bowers og Salas (2001) er den type kunnskap teamspesifikk og omhandler kjennskap til sterke sider, svakheter, preferanser og tendenser. Dette er kontekstuell kunnskap som spilleren ikke kan flytte med seg til andre lag, og når den deles, fremmes lagets ytelse ved at spillerne er bedre i stand til å forutsi hverandres handlinger, og den gir også spillerne mulighet til å kompensere for hverandre (Cannon-Bowers \& Salas, 2001). 


\section{Medspilleres sterke og svake sider}

I litteraturen fremheves rolleklarhet som en viktig forutsetning for effektiv samhandling i lagballspill på elitenivå (Giske et al., 2015). Vanligvis tenker vi oss at det er treneren som relativt uavhengig bestemmer hvilken spiller som skal bekle rollen, klargjør de grunnleggende bevegelsene i angitte rom og prioriterte handlingsvalg med ball, eller det som Collins og Collins (2011) refererer til som coachens masterplan. Det handler om å etablere tydelige forventninger til spesifikke handlinger i gitte spillesituasjoner, og forutsetter at både spilleren selv og medspillerne vet hva som mest sannsynlig kommer til å skje, eller hvordan laget ønsker å løse en gitt oppgave. Utsagn fra spillerne tyder imidlertid på at disse forventningene ikke bare er knyttet til oppgaven og rollen, men også til en unik spesifikk kunnskap om medspilleres svakheter og styrker.

Du vet at spiller X (spiss) er fantastisk god med ball i beina, så til han kan du spille harde pasninger, så kan han holde på han (ballen), så kan jeg stikke igjen, men hvis du spiller Y (spiss), så er ikke han så komfortabel med det, så da må du hele veien sørge for å voere tilgjengelig for han, så du gjør det enkelt for deg.

Utsagnet under viser kompleksiteten i et lagballspill, fordi motspillere har mulighet til å påvirke konteksten eller spillesituasjonen. I praksis betyr dette at det ikke bare er medspillere som forholder seg til sterke og svake sider, men at også motstanderen ofte vil gjøre det. Den tilpasningen som motstanderen gjør, vil ifølge spilleren i neste ledd få betydning for hvilke samspillsavtaler som gjøres. Fra et mer overordnet perspektiv illustrerer dette utsagnet også hvor integrert konteksten er i vurderingen av medspilleres sterke og svake sider.

Hvis X, som er en skytter som forsvaret er litt redd for, går opp på et kryss, så kan han plutselig spille meg fordi han har trukket på seg to, slik at jeg er ledig, mens en annen kanskje som er mindre og fintesterk, møter forsvaret annerledes. Da kan du ikke kjøre samme avtale med han.

Ifølge Cannon-Bowers og Salas (2001) fremmer medspillerkunnskap oppgaveutførelsen, og utsagnet under viser at intervjuobjektet relaterer styrke og svakheter i medspillernes kompetanse til konsekvenser for egne handlinger. I praksis betyr dette at spilleren tilpasser eget spill ut fra 
medspilleres styrker og svakheter. En av håndballspillerne uttrykker at det er store forskjeller på ulike spillere i like roller når han svarer:

Det er store forskjeller på hvem som spiller, og det er store forskjeller på hva de tenker, og hvilken teknikk de har, og om det passer for den personen.

Rolleklarhet er en viktig forutsetning for effektiv samhandling i lagspill (Giske et al., 2015; Carron, Hausenblas, \& Eyes, 2005), men intervjudataene tyder på at denne rollekunnskapen ikke er tilstrekkelig dekkende. Spilleren forteller nemlig at ulike spillere i samme spillerrolle leder til svært forskjellig prioriteringer og tilpasninger i spillet. Dette uttrykkes også tydelig av en av fotballspillerne:

Det er veldigforskjellig å spille med de to (de spiller begge spiss). Når jeg spilte med $X$, kunne jeg som kant stikke mye mer, som er min styrke, fordi han likte å møte, han var ikke så god å gå på bakrom. Spiller du med $Y$, så er han veldig sugen på å gå i bakrom; da må jeg voere veldig obs på å fylle rommet han stikker fra.

For øvrig er det verdt å merke seg at utsagnet ovenfor også viser at spilleren relaterer medspillerkunnskap til innsikt i egne sterke sider, noe som trolig er en viktig forutsetning for en effektiv gjensidig tilpasning av atferden i spillet. Betydningen av å forstå egne sterke sider og svakheter som en del av utviklingen som spiller blir ytterligere fremhevet noe senere $\mathrm{i}$ intervjuet med denne fotballspilleren:

Mange har spurt om hva som er den største forskjellen mellom lavere og høyere nivå [Her refererer respondenten til prestasjonsnivå - forfatternes kommentar]. Folk på høyere nivå er klar på hva de er god på og hva de ikke er god på. Det er tydeligere i Premier League [Her refererer respondenten til PL i England - forfatternes kommentar], så ser du han vet at det er det han kan, og da gjør han ikke det han ikke kan.

Å avklare genuint sterke og svake sider hos medspillere kan forstås som en teamspesifikk kunnskap som spilleren ikke kan nyttiggjøre seg i andre lag. Derimot kan kompetansen til å avdekke sterke og svake sider hos medspillere betraktes som en mer generisk kunnskap. På oppfølgende spørsmål om spillere leser medspilleres styrker og svakheter raskt, svarer en av fotballspillerne: 
Ja det vil jeg si. Jeg får et ganske kjapt inntrykk av hva de er gode på, og ikke gode på, og hvordan de tenker.

I realiteten betyr dette at den allmenne kunnskapen som trengs for å bedømme medspillernes styrker og svakheter, kan forstås som en kompetanse som gjør det mulig å utvikle spesifikk kunnskap om dette. Denne kompetansen kan spilleren transportere med seg fra lag til lag, og trolig vil den utvikles gjennom å eksponeres for spillere med forskjellige kvaliteter.

\section{Preferanser og prediksjon}

Ifølge Cannon-Bowers et al. (1993) er felles mentale modeller kunnskapsstrukturer hos spillerne som gjør det mulig å etablere en felles oppfatning av spillesituasjonen(e) og tydelige forventninger til medspilleres handlinger. Dette betyr at spilleren har kjennskap til medspillernes preferanser, og at vedkommende vil kunne predikere hva spilleren mest sannsynlig kommer til å gjøre i gitte situasjoner - eller at man er mer sikker på hva spilleren ikke kommer til å gjøre. En av fotballspillerne uttrykker eksplisitt betydningen av medspillerpreferanser:

Hvis jeg spiller med sentrale midtbanespillere som jeg vet er glad $i$ a ha ballen $i$ beina, så passer det meg veldig bra, fordi jeg liker å stikke - å linke opp på den måten.

Det er også her verdt å merke seg at spilleren nærmest automatisk og uten oppfordring relaterer det til at det passer ham - eller hans preferanser - i spillet. I litteraturen om felles mentale modeller foreligger det ikke, så langt vi har klart å bringe på det rene, en klargjøring av begrepene styrker og preferanser, men ut fra spillerens beretninger virker det som om disse nærmest er sammenfallende. Dette kan være et uttrykk for at det i lagballspill på elitenivå forventes at dine styrker som spiller kommuniseres og utnyttes som en preferanse av medspillerne.

Heller ikke forholdet mellom uttrykkene preferanse og prediksjon tematiseres i teorien om felles mentale modeller. Begge uttrykkene handler imidlertid om å etablere forventninger til medspillere i gitte situasjoner. En kan tenke seg at å oppfatte medspilleres preferanser eller handlingstendenser handler om å avdekke hva medspilleren helst ønsker 
å gjøre for eksempel med ball. Preferanse handler altså om hva som gis prioritet, mens prediksjon dreier seg mer om å angi ett av flere mulige utfall. Å ha god kunnskap om en medspilleres preferanse vil kunne bidra til større sannsynlighet for en nøyaktig prediksjon.

Følgende utsagn fra to av spillerne tyder på at en viktig del av kunnskapen om medspillere handler om å predikere eller lokalisere hvor spilleren er, nærmest uavhengig av faktisk observasjon i spillesituasjonen.

Spiller B vet jo at hver gang jeg spiller, så kan han ta et touch og pinge [slå en lang ball]. Han vet ... [hvor jeg er]

Den andre fotballspilleren uttrykker også at han kjenner medspilleren så godt at han ikke trenger å se på vedkommende for å vite hvor han er.

Jeg er vant til å spille med spillere som jeg kjenner veldig godt og som jeg vet akkurat hva gjør. Fra ung alder, så jeg ikke trenger å se på, en gang. Jeg vet hvor de er og kan forholde meg til det.

En av håndballspillerne uttrykker at små tegn eller kroppsspråk (blikk) benyttes for å fremme forutsigbarheten og koordineringen i spillet.

$X$ for eksempel, som spilte på venstrekanten. Der kunne vi bare se på hverandre, og kom det et blunk, så visste han at det kom en «flyger» hvis jeg går på mellom 2 er og 3er - eller at nå kommer det en «flyger» hvis jeg går mellom 1 og 2. Så da ser han gjennom det spillet jeg setter opp, og så vet han at den pasningen kommer.

Det er også verdt å merke seg at intervjuobjektet forsøker å sette opp spillet eller skape en spillesituasjon - eller nærmere bestemt skape en situasjonsutvikling som gjør det enklere for medspiller å vite hva han/hun skal gjøre. Spillernes mulighet til å skape en situasjonsutvikling som gir mønstergjenkjenning, er imidlertid lite påaktet i den foreliggende litteraturen, noe som trolig skyldes at undersøkelsene knyttet til felles mentale modeller primært er gjennomført i andre sammenhenger (militært eller flybesetninger) enn lagballspill. Mens man i tidligere undersøkelser har lagt vekt på en felles oppfatning av situasjonen (situational awareness), indikerer utsagnet at en vesentlig del av fellesforståelsen handler om å skape situasjonsbetingelser i kampen som gjør mønstergjenkjenning mulig, men uten at det avsløres for motstanderen. 
De fleste undersøkelser som er knyttet opp mot spillernes evne til prediksjon, er forbundet med laboratorieeksperimenter hvor spillernes evne til antesipasjon av ballbaner og spillerhandlinger basert på videoeksponeringer av ukjente spillere i ulike spillesituasjoner (Abernethy, 1991). Sitatene over tyder imidlertid på at vi også burde undersøke om spiller er bedre til å predikere medspillernes handlinger sammenliknet med en tilfeldig spiller. Dette ville kunne avklare hvor spesifikk eller generisk denne kunnskapen er.

\section{Kompenserende atferd}

Ifølge Cannon-Bowers og Salas (2001) gir medspillerkunnskap mulighet til kompenserende handlinger. På spørsmål fra intervjuer om fotballspilleren kompenserer defensivt hvis han spiller sammen med en offensiv indreløper svarer han:

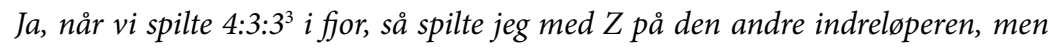
han var jo en «slakking», og det ble mer jobb på meg.

Dette utsagnet tyder på at spilleren tilpasser atferden med tanke på å kompensere, men det er mer uklart om det er tolkningen av spillesituasjonen mer enn medspillerkunnskapen som utgjør grunnlaget for disse handlingene. Dette kan bety at det er situasjonsoppfatningen som i større grad enn medspillerkunnskap bestemmer kompenserende handlinger. Utsagnet under fra den kvinnelige håndballspilleren, og som er knyttet til samhandling i forsvar, er spesielt illustrerende med tanke på hvor sammenvevd medspillerkunnskap, situasjonsoppfatning og kompenserende vurderinger er:

Har man en duellsvak treer ${ }^{4}$ ved siden av seg som ikke er så kjapp i beina og som ikke kan takle fintesterke spillere, så må jo man stå tettere og hjelpe hvis den spilleren blir passert. Har man en medspiller som er rask og god i mann-til-mann-situasjoner, behøver man ikke å flytte så mye over for å hjelpe til. Det vil jeg nesten si vi gjør hele veien.

3 For mer informasjon om 4:3:3 i fotball, se for eksempel Bergo med kolleger (2002).

4 De to treerne utgjør midtforsvaret i håndball. 
En nøkkelfaktor for effektiv samhandling innad i teamet er tilpasningsdyktighet (Cannon-Bowers \& Salas, 1998; Cannon-Bowers \& Bowers, 2006), og kompenserende atferd vil bero på spillerens oppfatning av oppgaven i spillesituasjonen og medspillerkunnskap. Følgende utsagn illustrerer dette:

Mye av min styrke som fotballspiller er at jeg legger fort merke til hva de rundt meg trenger, hvilke typer de er, og det bygger jeg mye av mitt spill rundt.

Cannon-Bowers og Salas (1998) fremhever at å kompensere for andres svakheter eller problemer gjennom å tilpasse seg situasjonen er en nøkkelkompetanse i effektivt teamarbeid. I både håndball og fotball er dette innarbeidet i for eksempel forsvar, hvor sikringsspill (to og tre forsvarere i fotball) ofte vil være en del av rolleforventningen. I dette tilfellet vil tilpasningsdyktigheten fremmes fordi rollene i teamet er overlappende. I praksis betyr dette at kompenserende atferd vil være et resultat av både situasjonsoppfatning, rolleforventning og medspillerkunnskap.

\section{Medspilleres valør}

I teorien om felles mentale modeller behandles medspillerkunnskap som et dekontekstualisert begrep hvor man kan få inntrykk av at alle medspillere er like betydningsfulle. Bourbousson med kolleger (2010) gjennomførte imidlertid en undersøkelse av koordinasjonen i et ungdomslag i basketball på høyt ferdighetsnivå. Analysene av spillerutsagnene etter videoeksponeringen viste at teammedlemmene tok hensyn til kun én medspiller i $49 \%$ av de offensive handlingsforløpene. Dette tyder på at ikke alle har lik valør hele tiden. En av fotballspillerne uttrykker dette på følgende måte:

$D u$ vil aldri «klikke» godt med alle, men hvis jeg spiller med spillere som har visse foretrukne bevegelser som gjør at jeg kan gjøre mine foretrukne bevegelser, så får du synergieffekten, men hvis jeg hele tiden må tilpasse litt fordi det passer ham, så blir det litt ujevnt - greit, så får vi ikke at $1+1=3$ lenger.»

Sitatet over er komplekst. Spilleren uttrykker eksplisitt at han ikke har like gode relasjoner til alle medspillerne. Deretter setter han ord på hva 
som karakteriserer relasjoner som gir synergier. Det handler om kunnskap om hverandres preferanser - eller om å utnytte og tilpasse spillet, slik at begge eksponerer sine styrker. I tillegg dreier utsagnet seg om en symmetri i relasjonen, og at synergieffekten ikke vil bli like fremtredende hvis det kun er den ene spillerens preferanser det trekkes veksler på. Det er med andre ord en opplevd gjensidig klar forestilling om hverandres styrker og svakheter når spilleren beretter om spesielt gode relasjoner på banen.

Den andre fotballspilleren trekker også frem at rollen til medspilleren kan ha betydning for valøren til medspillerkunnskap. Han sier:

Jeg kan forstå meg på han også, men han er midtstopper, det er veldig tydelig. Det er ikke mye kombinasjoner, det er ganske enkelt, det han foretar seg, så det er ganske greit å forholde seg til. Det er ikke slik at vi står og kombinerer og kombinerer. Det er litt forutbestemt hva han kommer til å gjøre, så det ganske greit å forholde seg til.

I praksis betyr dette trolig at betydningen av medspillerkunnskap er avhengig av sammenhengen mellom rollene i laget. Den kvinnelige håndballspilleren uttrykker dette på følgende måte:

Det er viktigst for meg å ha en bedre relasjon til de spillerne som jeg er mest ved siden av, som jeg spiller mest i noerheten av, men selvfølgelig er det viktig at man har en god relasjon til alle medspillere.

Utsagnet indikerer at dess mer samhandling rollene krever, dess større krav stilles det til medspillerkunnskap. Fysisk nærhet mellom rollene gjør at de er sterkere atferdsmessig avhengig av hverandre, og ifølge Malone og Crowston (1994) stiller dette skjerpede krav til koordinasjon.

Til tross for at flere forskere har vært opptatt av felles kunnskap i ballspillgrupper på elitenivå (Eccles \& Tenenbaum, 2004; Cannon-Bowers \& Bowers, 2006), har vi ikke funnet annen idrettspsykologisk litteratur som behandler dette temaet empirisk. Midtbanespilleren Ray Parlours fortelling om Arsenals «uovervinnelige» som gikk ubeseiret gjennom den engelske eliteserien i 2003/2004-sesongen, underbygger imidlertid at nærheten mellom rollene har betydning for å utvikle medspillerkunnskap:

If you play a section of the field, you've got to have a good understanding with the people around you. I wouldn't have a lot to do with whoever played left-back or 
left-winger, but I'd know to get in the box, to the back post if they get to the line. You have pockets in the team and you all know where you're going. (Bergkamp \& Winner, 2013, s. 227)

\section{Utvikling av medspillerkunnskap}

Cannon-Bowers med kolleger (1993) argumenterer for at det er tilnærmet umulig å trene lag slik at spillerne utvikler spesifikke forventninger til alle handlinger for enhver spillesituasjon. Målet med treningsopplegget bør derfor være at spillerne utvikler en kompetanse som gjør dem i stand til å ekstrapolere sin kunnskap om hvordan laget som helhet skal spille, noe som neste ledd gir spillerne mulighet til å etablere presise og raske forventninger til medspilleres handlinger (ibid.). De første praktiske forslagene til effektiv lagtrening for å fremme felles mentale modeller inneholder tiltak som informasjonsbaserte forelesninger, videobaserte demonstrasjoner og øving (Salas \& Cannon-Bowers, 1997). Så langt vi har klart å bringe på det rene, er det få vitenskapelige arbeider som omhandler utviklingen av teamspesifikk kunnskap og eventuelt didaktiske opplegg med eksplisitte mål om å påvirke dette. På spørsmål om treneren for eksempel tar opp styrker og svakheter til medspillere, svarer en av spillerne:

Dette er bare en følelse som du får. Det er ikke noe som blir tematisert. Selvfølgelig, hvis du ser tydelig at han og han gjør fantastiske ting sammen, så kan det bli tatt opp. Og det bør bli lagt merke til, mener jeg, fordi jeg mener at noe av det viktigste ute på en fotballbane er gode relasjoner - folk som fungerer sammen - folk som vet hvor folk er.

Utsagnet tyder på at dette er et forhold som trenerne i liten grad retter oppmerksomheten mot, og intervjuobjektet uttrykker at det i sterkere grad burde ha vært markert. Det er interessant å merke seg at spilleren svarer at styrker og svakheter hos medspillere er «bare en følelse som du får». Utsagnet kan tyde på at medspillerkunnskap i all hovedsak tilegnes via implisitte læringsprosesser (Reber, 1993), og sjelden læres intensjonalt. Imidlertid vil enhver samhandlingsaktivitet (øvelser og spill) i et lag gi spillerne mulighet til å lære hvordan vi sammen bør løse oppgavene på best mulig måte (generisk kunnskap om spillet), samtidig som det gir anledning til å analysere 
medspilleres kompetanse i samme øvelse eller spill. Eccles og Tenenbaum (2004) argumenterer for at spillerne tilegner seg og raffinerer sin felles kunnskap gjennom erfaring og øving. Kampaktiviteten, hvor både kampplaner og kampevalueringer inngår, vil være forhold som vil kunne fremme spillernes felles kunnskap. Ifølge Eccles og Tenenbaum (2004) muliggjør denne omfattende påirkningen en implisitt koordinering av spillernes handlinger. Det kan også virke som om det ikke bare er koordineringen mellom spillerne som er implisitt, men også mye av læringsprosessen i et elitelag i ballspill. En av spillerne svarer på spørsmål om relasjonen mellom spillerne på banen tematiseres i forbindelse med arbeidet etter kamp:

Det diskuteres veldig lite, men det er så ekstremt implisitt. [I: Initieres dette fra trenerne, eller er dette noe som dere igangsetter selv?] Nei, nei det har ingenting med det å gjøre [trenere]. Vi som er litt eldre og har voert i gamet lenge, vi vet hva som skal til, og alt handler om å vinne og om hvordan vi skal få det beste ut av hverandre.

Utsagnet støtter en antakelse om at mye av medspillerkunnskapen etableres som et resultat av implisitte læringsprosesser. Siden dette i liten grad synes å være et forhold som eksplisitt er tematisert av trener, er det nærliggende å tenke at det diskuteres mellom spillerne. En av dem svarer:

Nei, jeg kunne gi litt tips av og til hvis jeg skulle spille kant, til for eksempel en nummer 10. Jeg liker jo veldig å gå inn, skjore inn rundt spissens bakrom. Da har jeg alltid gitt beskjed til tieren om at jeg blir fulgt av en back. Tieren sin oppgave er jo å finne rom, så hvis du detter litt ned inn i mitt rom, så vil det alltid vore masse rom for deg.

Utsagnet overfor tyder på at medspillerkunnskap i liten grad tematiseres eksplisitt i diskusjoner mellom spillerne, og det forsterker antakelsen om at utviklingen av denne kunnskapen primært følger implisitte læringsbaner.

Utsagnet under forteller at spilleren opplever at ballen er et kommunikasjonsverktøy som brukes til å formidle til medspillerne at han er en spiller en kan stole på. I praksis betyr dette at utviklingen av medspillerkunnskap også dreier seg om at «én ball» og «én pasning» er noe langt mer enn det. 
Jeg er mye mer bevegelig, så jeg søker hele veien å gi dem mye mer ball, fordi da sender jeg et signal til vedkommende om at du stoler på han, og da får han en god kjemi til meg.

Slik spilleren velger å uttrykke seg om ballen, kan den forstås som et medierende redskap, dvs. et kulturelt redskap som spilleren bruker for å forstå og reagere på omverden på (Vygotsky, 1978). Spilleren mener at ved å gi ballen fra seg til medspillere bygger han opp tillit - og dessuten en god kjemi eller en sterkere følelsesmessig relasjon til medspillerne. Det å forstå ballen som et implisitt kommunikasjonsmedium, slik spilleren gjør, er et perspektiv som i liten grad har vært tematisert i faglitteraturen.

Basert på intervjumaterialet er det grunn til å tro at medspillerkunnskap etableres gjennom samhandling, og at denne kunnskapen er en del av konteksten og dermed ikke kan forstås løsrevet fra denne sammenhengen. Utviklingen av medspillerkunnskap kan trolig best forstås som situert læring, dvs. at læringen finner sted i samme sammenheng som en skal bruke det lærte (Lave \& Wenger, 1991).

\section{Oppsummering}

Hensikten med denne undersøkelsen var å utforske medspillerkunnskap på elitenivå i ballspill - teoretisk forankret i felles mentale modeller. Ifølge Cannon-Bowers og kolleger (1993) kan teamkunnskap kategoriseres som generisk eller spesifikk. Medspillerkunnskap er teamspesifikk og kontekstuell, og kan derfor ikke transporteres over til andre kontekster og team.

Medspillerkunnskap handler om kjennskap til medspilleres sterke og svake sider, preferanser og prediksjon samt kompenserende atferd. Intervjumaterialet avdekker at medspillere har ulik valør, og fra et mer overordnet perspektiv viser resultatene hvor viktig denne kunnskapen er for samhandlingen i både fotball og håndball på elitenivå. Cannon-Bowers og Salas (2001) argumenterer for at medspillerkunnskap vil fremme oppgaveutførelsen fordi spillerne blir bedre kjent med hverandre og kan tilpasse sin atferd i samsvar med hva de kan forvente. Disse forventningene kan etableres gjennom rolleavklaringer og utvikling av medspillerkunnskap. I praksis handler det totalt sett om å kunne predikere hverandres 
handlinger, slik at spillet innad i laget blir mer forutsigbart. Kjennskap til styrker, svakheter og preferanser hos medspillere i gitte spillerroller vil tydeliggjøre forventninger og bidra til økt forutsigbarhet, noe som i neste ledd vil fremme koordineringen eller samhandlingen (Cannon-Bowers et al., 1993).

Resultatene tyder på at betydningen av medspillerkunnskap beror på sammenhengen mellom rollene i laget, dvs. dess mer samhandling rollene krever, dess større krav stilles det til medspillerkunnskap. Når det gjelder svaret på spørsmålet om hvordan respondentene opplever at kunnskap om medspillere dannes, tyder resultatene på at kunnskapsutviklingen primært følger implisitte læringsbaner.

Basert på foreliggende forskning foreslår Salas, Cannon-Bowers og Johnston (1997) flere retningslinjer for hvordan et team av eksperter kan utvikles til et ekspertteam. Noen av tiltakene de foreslår, er utvikling av felles kompatible mentale modeller av oppgaven - koblet til nøkkelelementer for hvordan løsningen av den skal være. Dette handler om å etablere holdepunkter for samspillet mellom rollene i ulike spillesituasjoner (det er spillesituasjonene som definerer oppgaven). De fremhever imidlertid at tiltakene ikke bare skal rettes mot oppgavene, men også knyttes opp mot medspillerkunnskap. Resultatene fra den foreliggende undersøkelsen understøtter betydningen av medspillerkunnskap i håndball og fotball på elitenivå. Trenere og spillere bør derfor reflektere over hvordan denne kunnskapen skal fremmes.

\section{Undersøkelsens sterke og svake sider}

Denne undersøkelsen er ikke uten begrensninger, og det må man være bevisst på i tolkningen av det empiriske materialet. Det er et relativt lite antall deltakere i undersøkelsen, og dette bør tas hensyn til. Etter vår mening dekker imidlertid det innsamlede empiriske materialet fenomenet i den forstand at det avdekker sentrale karakteristika ved medspillerkunnskap i håndball og fotball. Flere intervjuer ville trolig ikke avsløre noe fullstendig nytt eller forskjellig. Lincoln og Guba (1999) argumenterer for at «tykke beskrivelser» og «langvarig involvering» $\mathrm{i}$ feltet er viktige forutsetninger for å etablere troverdighet. Særlig det siste er 
godt ivaretatt, da flere av forfatterne har lang erfaring både som spillere og trenere på høyt ferdighetsnivå i de aktuelle lagballspillene. Braun og Clark (2006) fremhever at en svakhet med tematisk analyse er begrenset tolkningskraft utover beskrivelsene ved fravær av et teoretisk rammeverk som forankrer analysen. I den forliggende undersøkelsen har felles mentale modeller vært et teoretisk utgangspunkt som vi mener har gitt forankringen og analysen den nødvendige dybden.

\section{Referanser}

Apitzsch, E. (2009). Coaches' and elite players' perception and experiencing of collective collapse. Athletic Insight. The Online Journal of Sport Psychology, 11(2). Retrieved from http://www.athleticinsight.com/Vol11Iss2/Collapse.html

Bergkamp, D. \& Winner, D. (2013). Stillnes and speed - my story. London, UK: Simon \& Schuster.

Bergo, A., Johansen, P.A., Larsen, Ø., \& Morisbak, A. (2002). Ferdighetsutvikling $i$ fotball: Handlingsvalg og handling. Oslo, Norge: Akilles.

Bourbousson, J., Poizat, G., Saury, J., \& Seve, C. (2010). Team coordination in basketball: Description of the cognitive connections among teammates. Journal of Applied Sport Psychology, 22, 150-166.

Braun, V. \& Clarke, V. (2006). Using thematic analysis in psychology. Qualitative Research in Psychology, 3, 77-101.

Cannon-Bowers, J.A. \& Bowers, C.A. (2006). Applying work team results to sports teams: Opportunities and cautions. International Journal of Sport and Exercise Psychology, 4, 447-462.

Cannon-Bowers, J.A. \& Salas, E. (2001). Reflections on shared cognition. Journal of Organizational Behavior, 22, 195-202.

Cannon-Bowers, J.A., Salas, E., \& Converse, S. (1993). Shared mental models in expert team decision-making. I N.J. Castellan, Jr. (red.), Individual and group decision making (s. 221-246). Hillsdale, NJ: Lawrence Erlbaum Associates.

Carron, A.V., Hausenblas, H.A., \& Eyes, M.A. (2005). Group Dynamics in Sport. Morgantown, WV: Fitness Information Technology.

Carson, M. (2013). The manager: Inside the minds of football's leaders: Bloomsbury Publishing.

Collins, D. \& Collins, J. (2011). Putting them together: skill packages to optimize team/group performance. I D. Collins. A. Button \& H. Richards (red.), Performance Psychology. A Practitioner's Guide (s. 361-391). Churchill Livingstone: Elsevier. 
DeChurch, L.A. \& Mesmer-Magnus, J.R. (2010). The cognitive underpinnings of effective teamwork: A meta-analysis. Journal of Applied Psychology, 95, 32-53. Eccles, D.W. \& Tenenbaum, G. (2004). Why an expert team is more than a team of experts: A social-cognitive conceptualization of team coordination and communication in sport. Journal of Sport and Exercise Psychology, 26, 542-560.

Endsley, M.R. (1995). Toward a theory of situation awareness in dynamic systems. Human Factors, 37, 32-64.

Fiore, S.M., Salas, E., \& Cannon-Bowers, J.A. (2001). Group dynamics and shared mental model development. I M. London (red.), How people evaluate others in organizations: Person perception and interpersonal judgment in industrial/ organizational psychology (s. 309-336). Mahwah, NJ: Erlbaum.

Giske, R., Rodahl, S.E., \& Høigaard, R. (2015). Shared mental task models in elite ice hockey and handball teams: Does it exist and how does the coach intervene to make an impact? Journal of Applied Sport Psychology, 27, 20-34.

Giske, R., Rodahl, S.E., Haugen, T., \& Høigaard, R. (2017). Shared mental models, role ambiguity, team identification and social loafing in elite sports groups: A mediation analysis. Sport \& Exercise Psychology Review, 13, 2-12.

Giske, R., Gjerde, J., Gaard, H.S., Høigaard, R., \& Johansen, B.T. (2018). Shared Mental Models in Elite Interaction Ball-Game Teams: A thematic analysis of soccer and handball coaches' thinking on importance, characteristics, and development. (Under utarbeidelse)

Klein, G. (2009). Streetlights and shadows: Searching for the keys to adaptive decision making. Cambridge, MA: MIT Press.

Langan-Fox, J., Wirth, A., Code, S., Langfield-Smith, K., \& Wirth, A. (2001). Analyzing shared and team mental models. International Journal of Industrial Ergonomics, 28(2), 99-112.

Langan-Fox, J., Anglim, J., \& Wilson, J.R. (2004). Mental models, team mental models, and performance: Process, development, and future directions. Human Factors and Ergonomics in Manufacturing \& Service Industries, 14(4), 331-352.

Lave, J. \& Wenger, E. (1991). Situated learning: Legitimate peripheral participation. New York, NY: Cambridge University Press.

Lincoln, Y. \& Guba, E. (1999). Establishing trustworthiness. I A. Bryman \& R.G. Burgess (red.), Qualitative Research Volum III (s. 397-444). London: Sage Publications.

Malone, T.W. \& Crowston, K. (1994). The interdisciplinary study of coordination. ACM Computing Surveys, 26, 87-119.

Martens, R. (1987). Science, knowledge and sport psychology. The Sport Psychologist, 1, 29-55. 
Miles, M.B., Huberman, A.M., \& Saldana, J. (2014) Qualitative data analysis. Los Angeles, CA: Sage.

Patton, M.Q. (2002). Qualitative interviewing. Qualitative Research and Evaluation Methods, 3, 344-347.

Reber, A.S. (1993). Implicit learning and tacit knowledge: An essay on the cognitive unconscious. New York, NY: Oxford University Press.

Reimer, T., Park, E.S., \& Hinsz, V.B. (2006). Shared and coordinated cognition in competitive and dynamic task environments: An information-processing perspective for team sports. International Journal of Sport and Exercise Psychology, 4, 376-400.

Rouse, W.B. \& Morris, N.M. (1986). On looking into the black box: Prospects and limits in the search for mental models. Psychological Bulletin, 10o(3), 349-363.

Rubin, H.J. \& Rubin, I.S. (1995). Qualitative interviewing: The art of hearing data. Thousand Oaks, CA: Sage.

Salas, E., Cannon-Bowers, J.A., \& Johnston, J.H. (1997). How can you turn a team of experts into an expert team? Emerging training strategies. I C.E. Zsambok \& G. Klein (red.), Naturalistic Decision Making (s. 359-370). Mahwah, NJ, USA: Erlbaum Associates.

Salas, E., Benishenk, L., Coultas, C., Dietz, A., Grossman, R., Lazzara, E., \& Oglesby, J. (2015) Team training essentials. A research-based guide. New York, NY: Routledge.

Salmon, P.M., Stanton, N.A., Walker, G.H., Baber, C., Jenkins, D.P., McMaster, R., \& Young, M.S. (2008). What really is going on? Review of situation awareness models for individuals and teams. Theoretical Issues in Ergonomics Science, 9(4), 297-323. Silverman, D. (2011). Interpreting qualitative data: a guide to the principles of qualitative research (4. utg.). Los Angeles: Sage.

Tracy, S.J. (2010). Qualitative quality: Eight “big-tent" criteria for excellent qualitative research. Qualitative Inquiry, 16, 837-851.

Vealey, R.S. (1994). Knowledge development and implementation in sport psychology: A review of the sport psychologist, 1987-1992. The Sport Psychologist, 8, 331-348.

Vygotsky, L.S. (1978). Mind and society. Cambridge, MA: Harvard University Press.

Ward, P. \& Eccles, D.W. (2006). A commentary on 'Team cognition and expert teams: Emerging insights into performance for exceptional teams'. International Journal of Sport and Exercise Psychology, 4, 463-483. 



\title{
Sammenhengen mellom mindfulness og eksekutiv funksjon hos profesjonelle fotballspillere
}

\author{
Anders Meland ${ }^{1 \star}$, Per-Mathias Høgmo ${ }^{2}$, Kazuma Ishimatsu ${ }^{3}$, \\ Anthony Wagstaff', \& Anne Marte Pensgaard ${ }^{4}$ \\ ${ }^{1}$ Flymedisinsk institutt, Oslo; ${ }^{2}$ Universitetet i Tromsø; ${ }^{3}$ Graduate School of Health \\ Care Sciences, Jikei Institute, Osaka, Japan; ${ }^{4}$ Norges idrettshøgskole, Oslo
}

\begin{abstract}
Sammendrag: En høy grad av mindfulness anses for å være fordelaktig for idrettsutøvere, og mindfulness-trening har derfor blitt en populær metode innenfor prestasjonsutvikling. Dette til tross for at kunnskapen om sammenhengen mellom å være mindful og viktige prestasjonsvariabler er mangelfull. Dette er særlig et problem for trenere og idrettsutøvere som konkurrerer på det høyeste nivået, der eventuelle ulemper ved mindfulness lett kan utkonkurrere fordelene. I denne studien undersøkte vi sammenhengen mellom selvopplevd grad av fem ulike fasetter av mindfulness og prestasjon på to ulike PC-baserte tester på inhibitorisk kontroll hos 42 profesjonelle fotballspillere. Resultatene viste at observasjonsfasetten av mindfulness var assosiert med bedre prestasjon på én av testene, og at fasetten som måler grad av ikke-dømming, var assosiert med svakere prestasjon på begge PC-testene på grunn av mer impulsiv respons. Disse funnene tyder på at mindfulness og eksekutiv funksjon henger sammen, men at sammenhengen kanskje ikke bare er fordelaktig.
\end{abstract}

Nøkkelord: mindfulness, lagspill, eksekutiv funksjon, inhibisjon

\begin{abstract}
Mindfulness has become a popular tool for athletes, but the knowledge about the exact associations between trait mindfulness and key performance variables are lacking. This is especially problematic for athletes competing at a higher level where minor costs of a trait or an intervention could easily outweigh the benefits. In this study we investigated the association between self-reported level of mindfulness and performance on two PC based tests of inhibitory control on forty-two professional soccer players. The results showed that the observation facet of mindfulness was associated with better performance on one of the tests, while the non-judgement facet was associated with lower performance on both tests due to more impulsive responding. These findings suggest that trait mindfulness and inhibitory control is related, but that the relationship may not only be beneficial.
\end{abstract}

Keywords: mindfulness, team sports, executive function, inhibition

\footnotetext{
*Korresponderende forfatter: Anders Meland, Flymedisinsk institutt, Oslo. E-post: anders.meland@flymed.uio.no, Tlf.: +47 229303 44, Mobil: +47 95227 021, Sem Sælandsvei 2B, o371 Oslo

Sitering av denne artikkelen: Meland, A., Høgmo, P.M., Ishimatsu, K., Wagstaff, A. \& Pensgaard, A.M. (2018). I T. Haugen \& R. Høigaard (red.). Trender i idrettspsykologisk forskning i Skandinavia (Kap. 9, s. 187-204). Oslo: Cappelen Damm Akademisk. DOI: https://doi.org/10.23865/noasp.39.ch9

Lisens CC-BY 4.0
} 


\section{Introduksjon}

På generelt plan omtales individer med høy grad av mindfulness som årvåkne, til stede og i kontakt med livet «her-og-nå». De beskrives som mennesker med høy bevissthet omkring alle stimuli, men opplever samtidig færre distraksjoner og reagerer mindre reaktivt i møte med følelser (Bishop et al., 2004; Brown, Ryan, \& Creswell, 2007). Siden dette også er ønskelige egenskaper i idrettssammenheng for å bedre prestasjonene og redusere de negative konsekvensene av stress, har det å være mindful blitt sett på som et fordelaktig trekk (Birrer, Rôthlin, \& Morgan, 2012). Studier på normalbefolkningen viser at å være mindful innebærer økt sensitivitet til relevant informasjon, mindre sårbarhet for distraksjoner og mer effektiv oppgaveløsning (Tang, Holzel, \& Posner, 2015). Denne sammenhengen er ikke like godt dokumentert hos idrettsutøvere. Riktignok finnes det studier på utøvere som viser en gunstig sammenheng mellom det å være mindful og prestasjonsrelaterte variabler som for eksempel oppgavefokus, flow, velvære og stressmestring (Birrer et al., 2012; Röthlin, Horvath, Birrer, \& Grosse Holtforth, 2016; Sappington \& Longshore, 2015). For øvrig er bare én av disse studiene utført på idrettsutøvere på høyt nivå (Röthlin et al., 2016). Ingen av dem har inkludert objektive mål på kognitiv funksjon eller sett på forskjeller mellom de ulike fasettene $\mathrm{i}$ mindfulness. For å bedre beslutningsgrunnlaget for å ta i bruk mindfulness-trening i toppidrettsmiljøer var målet med denne studien å undersøke sammenhengen mellom grad av mindfulness og eksekutiv funksjon hos toppidrettsutøvere.

\section{Mindfulness-fasettene}

Bishop et al. (2004) hevder at å være mindful innebærer økt grad av selvregulerings- og monitoreringsevne. Selvregulering refererer til evnen til å undertrykke eller vende tilbake fra distraksjoner. Monitorering innebærer å forholde seg åpen overfor erfaringer, uavhengig av innhold eller ønskelighet. Baer, Smith, Hopkins, Krietemeyer, and Toney (2006) fant, ved hjelp av faktoranalyse av resultatene fra fem ulike spørreskjema som måler mindfulness, at å bli mer mindful innebærer en økning på fem overlappende, men ulike fasetter eller ferdigheter: 
- Observere - legge merke til indre og ytre hendelser og erfaringer

- Beskrive - sette ord på erfaringer i og utenfor kroppen

- Handle bevisst - legge merke til det en sier og gjør

- Ikke-dømme - en ikke-evaluerende innstilling til indre erfaringer

- Ikke-reagere - la tanker og følelser komme og gå uten å overreagere eller å bli fanget av dem

\section{Inhibisjon}

Våre eksekutive funksjoner spiller en sentral rolle i menneskelig kognisjon og atferd, og vår evne til inhibisjon regnes som den mest sentrale av våre eksekutive funksjoner (Miyake \& Friedman, 2012). Inhibisjon innebærer evnen til å stoppe og hemme igangsatte responser, og har derfor en sentral rolle i vår evne til å styre oppmerksomheten og de motoriske handlingene. Det finnes flere underkategorier av inhibisjon, og i denne studien undersøkte vi to ulike former: 1) Evnen til å stoppe en automatisert motorisk handling, såkalt responsinhibisjon (Verbruggen \& Logan, 2008). 2) Evnen til å stoppe prosessering av en plutselig oppdukkende og irrelevant stimulus som tiltrekker seg oppmerksomheten (Theeuwes, 2014). Manglende evne til respons-inhibisjon kan føre til uhensiktsmessig og vanemessig respons i situasjoner som krever noe mer enn kun automatisert handling (Helton, 2009). Manglende inhibisjon i forbindelse med plutselig oppdukkende stimuli kan forstyrre hensiktsmessig søkestrategi og involvere unødvendig prosessering av irrelevante stimuli (Theeuwes, 2014).

I de fleste situasjoner kan vi kompensere for behovet for inhibisjon ved å ta oss tid til å observere hele situasjonen og/eller saktne farten, slik at vi kan unngå å gjøre feil. Dette er ikke mulig i uforutsigbare situasjoner med tidspress. Evnen til å inhibere er derfor spesielt viktig i komplekse idretter med hurtige skifter og situasjoner som krever overstyring av reflekser og automatiske responser (Voss, Kramer, Basak, Prakash, \& Roberts, 2010). Studier har vist at unge elitespillere i fotball presterer bedre enn ikke-elitespillere på tester som måler generell eksekutiv funksjon (Vestberg, Gustafson, Maurex, Ingvar, \& Petrovic, 2012), og responsinhibisjon (Huijgen et al., 2015; Verburgh, Scherder, van Lange, \& Oosterlaan, 2014). 


\section{Sammenhengen mellom mindfulness og inhibisjon}

Graden av mindfulness er funnet å ha positiv sammenheng med evnen til inhibisjon i normalbefolkningen (Gallant, 2016). Forklaringer på denne positive sammenhengen kan være at mindfulness fører til mindre tankevandring og økt bevissthet på egne responser - og dermed bedre rekruttering av vår eksekutive funksjon (Cheyne, Carriere, \& Smilek, 2006; Teper, Segal, \& Inzlicht, 2013). Imidlertid er det ingen studier som har undersøkt sammenhengen mellom mindfulness og inhibisjon hos idrettsutøvere, og forskningen på andre grupper peker i ulik retning. Enkelte studier har funnet en positiv sammenheng mellom mindfulness og prestasjon på responsinhibisjon (Cheyne et al., 2006; Jha et al., 2015; Jha, Morrison, Parker, \& Stanley, 2017; Josefsson \& Broberg, 2010; Sahdra et al., 2011; Schmertz, Anderson, \& Robins, 2009). Andre studier viser en negativ sammenheng (Larson, Steffen, \& Primosch, 2013; Saunders, Rodrigo, \& Inzlicht, 2015), eller ingen sammenheng (MacCoon, MacLean, Davidson, Saron, \& Lutz, 2014). En mulig forklaring på de motstridene funnene kan være at disse studiene har benyttet en samlet mindfulness-score, og ikke skilt mellom de ulike fasettene. Vi fant ingen tidligere studier som har undersøkt sammenhengen mellom mindfulness og inhibisjon ved oppdukkende irrelevante stimuli, såkalte oppmerksomhetsfangere.

Hensikten med denne studien var å undersøke sammenhengen mellom de fem fasettene av mindfulness som er beskrevet av Baer et al. (2006), og objektive markører for inhibisjon hos profesjonelle fotballspillere. Vi valgte fotballspillere fordi de effektivt må kunne monitorere situasjoner for relevant informasjon, overse distraksjoner og reagere hensiktsmessig uten mulighet til å redusere farten for å unngå feil (Coutts, 2016). Basert på teori og studier av normalbefolkningen var hypotesen å finne en positiv sammenheng mellom prestasjon på inhibisjonstestene og alle mindfulness-fasettene.

\section{Metode}

\section{Deltakere og prosedyre}

Vi testet 42 mannlige fotballspillere fra eliteserien $(n=21)$ og Adecco-ligaen $(n=21)$ i Norge (gjennomsnittlig alder $=26,5$, standardavvik $=5,1$ ). 
Spillerne ble rekruttert gjennom å kontakte hovedtrener på to lag. Datainnsamlingen foregikk på de respektive lagenes hjemmearena før en ordinær treningsøkt. For å unngå utilsiktet støyforstyrrelse og sikre mest mulig like forhold for alle, ble PC-testene gjennomført i et rom der spillerne kunne sitte uforstyrret. Spillerne brukte i tillegg høretelefoner med støyreduksjon under testene (Bose QC15, Bose Corporation, Massachusetts, U.S.). De fikk to minutters pause mellom de to PC-testene. Ingen av spillerne drev med eller hadde tidligere drevet med mindfulness-trening. Studien var godkjent av REK sør-øst, og deltakelsen var frivillig.

\section{Måleinstrumenter}

\section{Mindfulness}

Graden av mindfulness ble målt med den norske versjonen av The Five Facet Mindfulness Questionnaire (FFMQ; Dundas, Vøllestad, Binder \& Sivertsen, 2013). Den består av 39 spørsmål som scores på en fempunkts Likert-skala, fra (1) (aldri, eller veldig sjelden sant) til (5) (Veldig ofte eller alltid sant). Eksempel på spørsmål som måler de ulike fasettene: Observere: «Jeg legger merke til sanseopplevelser, som vinden $\mathrm{i}$ håret mitt eller solen mot ansiktet.» Beskrive: «Jeg er flink til å finne ord for å beskrive følelsene mine.» Handle bevisst: «Jeg oppdager at jeg gjør ting uten å være oppmerksom.»Ikke-dømme: «Jeg kritiserer meg selv for å ha ufornuftige eller upassende følelser.» Ikke-reagere: «Jeg legger merke til følelsene mine uten at jeg trenger å reagere på dem.»

Chronbach alpha på .70 regnes som gode verdier på intern konsistens mellom spørsmålene, men verdier ned til o.6o kan vurderes som akseptable (Nunnally \& Bernstein, 1994). Alle fem fasettene, bortsett fra beskrive, hadde god intern konsistens: observere: $\alpha=.82$, beskrive: $\alpha=.60$, handle bevisst: $\alpha=.86$, ikke-dømme: $\alpha=.87$, ikke-reagere: $\alpha=.78$.

The sustained attention to response task (SART; Robertson, Manly, Andrade, Baddeley, \& Yiend, 1997) tester responsinhibisjon og tar ca. 4 minutter og 20 sekunder å gjennomføre. Deltakeren får presentert ett og ett tall i tilfeldig rekkefølge på en skjerm, der oppgaven er å respondere med et trykk på «space»-knappen på PC-en på alle tall, bortsett fra tallet 3. Andelen 3-ere er kun $11 \%$ av tallene, noe som gjør at deltakerne 
skal komme inn i en vanemessig trykking på «space»-knappen, og dermed blir testen ekstra utfordrende. SART har tidligere vist seg å være sensitiv overfor svikt i konsentrasjon og responsinhibisjon hos idrettsutøvere (Ishimatsu, Meland, Hansen, Kåsin, \& Wagstaff, 2016). Prestasjon måles ved 1) antall feiltrykk på tallet 3;2) manglende trykk på de andre tallene; 3 ) tiden det tar å respondere på tallene, foruten tallet 3 (Wilson, Russell, \& Helton, 2015). Feiltrykk på tallet 3 indikerer manglende inhibisjon, imens manglende trykk på de andre tallene indikerer svikt i konsentrasjon. En rask eller treg reaksjonstid kan være en indikasjon på svikt i konsentrasjon, men også en bevisst strategi om å respondere raskt eller en strategi for å unngå å trykke på tallet 3 .

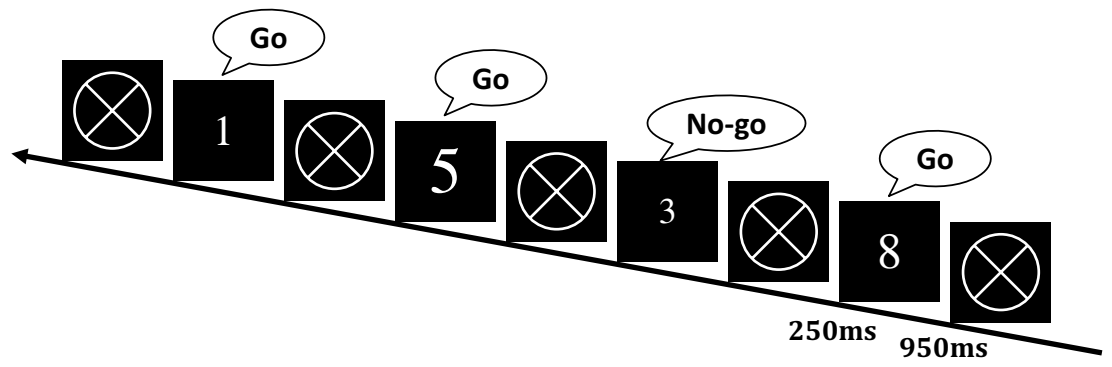

Figur 1. Illustrasjon på rekkefølge, tiden stimulus vises og tiden mellom stimuli i hver omgang på Sustained Attention to Response Test (SART).

The attentional capture task (ACT; Theeuwes \& Chen, 2005) tester inhibisjon i forbindelse med oppdukkende irrelevante stimuli, såkalte oppmerksomhetsfangere. På grunn av at fotballspillerne har begrenset med tid til rådighet, gjennomfører vi en forkortet versjon ( $15 \mathrm{~min}$ ) av den opprinnelige testen. Deltakerne får presentert et skjermbilde der oppgaven er å bestemme om en linje som dukker opp på innsiden av en diamant, er vertikal eller horisontal. Diamanten dukker tilfeldig opp på seks ulike steder på skjermen. I 83\% av omgangene blinker det en irrelevant rød sirkel i $60 \mathrm{~ms}$ (oppfattes som et «blink») på en av de seks posisjonene rett før diamanten vises (Fig. 2). Det er dette røde blinket som automatisk fanger oppmerksomheten, og som kalles «attentional capture»-effekten. Testen krever inhibering av den oppdukkende irrelevante røde sirkelen. Prestasjon måles ved tiden det tar å bestemme om det er en horisontal eller vertikal linje inni diamanten i fem ulike settinger: 
Setting 1: Ingen distraksjon: ingen rød sirkel.

Setting 2: 0: Rødt blink på samme posisjon som målet.

Setting 3: 1: Rødt blink på posisjon ved siden av målet.

Setting 4: 2: Rødt blink på posisjon nest nærmest målet.

Setting 5: 3: Rødt blink på posisjon lengst unna målet.

Sensitiviteten $(d$ ') til den horisontale/vertikale linjen ble beregnet som et mål på inhibisjon av «attentional capture»-effekten i de fem settingene. Dette er basert på reaksjonstid, antall riktige/feil responser (for kalkulasjon se Stanislaw \& Todorov, 1999).

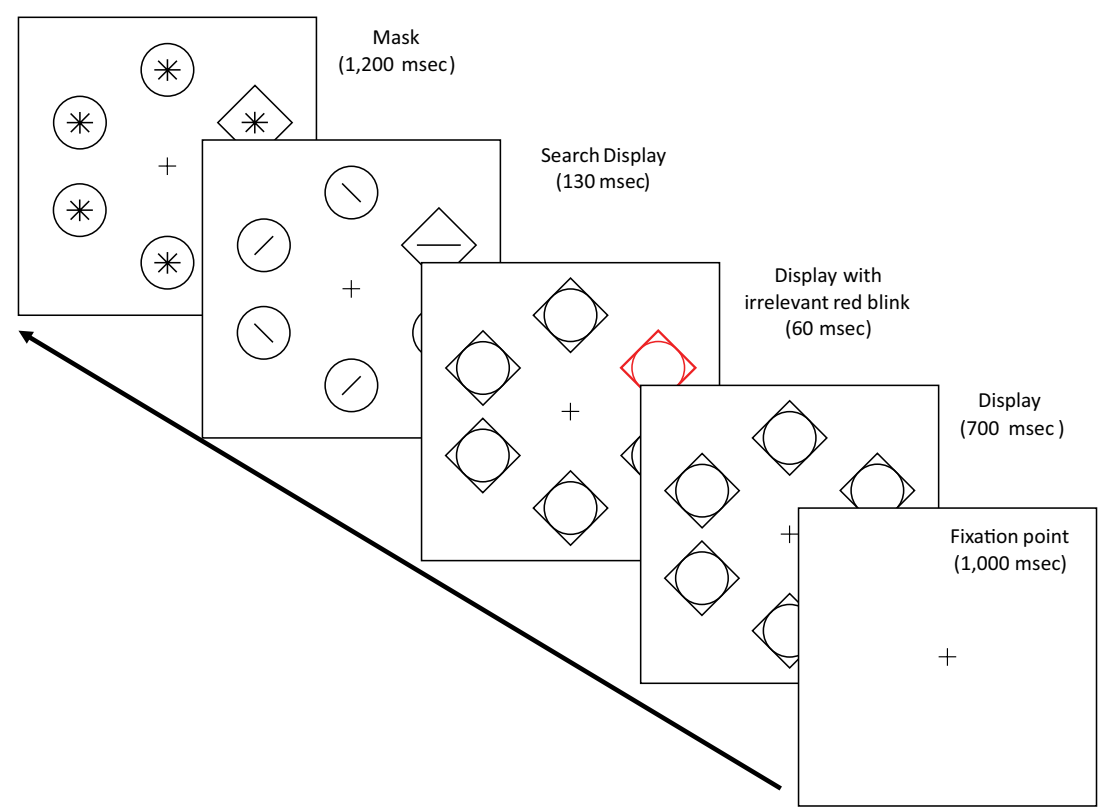

Figur 2. Illustrasjon på sekvens, tiden stimulus vises og tiden mellom stimuli i hver omgang på Attentional Capture Test (ACT).

\section{Statistikk}

Gjennomsnitt og Pearson's product-moment-korrelasjon ble beregnet for de ulike mindfulness-fasettene og mellom fasettene og prestasjon på de to PC-testene. Signifikansnivået ble satt til $p<.05$ for alle analyser. Analysene baserer seg på data fra 42 spillere på FFMQ og SART, men 
kun 40 spillere på ACT, da to spillere ikke fikk tid til å gjennomføre hele testen.

\section{Resultater}

Korrelasjonsanalysen mellom de ulike mindfulness-fasettene viser (tabell 1) signifikant sammenheng kun mellom observere- og ikkereagere-fasettene. Analysene av SART viser (tabell 3) at observere var negativt korrelert med antall feiltrykk på tallet 3 og positivt korrelert med gjennomsnittlig reaksjonstid på de øvrige tallene. Vi fant videre at ikke-dømme var positivt korrelert med antall feiltrykk på tallet 3. Handle bevisst var negativt korrelert med antall manglende trykk, og ikke-reagere var positivt korrelert med reaksjonstid. Beskrive-fasetten viste ingen signifikant sammenheng med prestasjonsmålene på noen av testene. Etter at vi kontrollerte for reaksjonstid i en partiell korrelasjonsanalyse (tabell 4), var observere fortsatt negativt korrelert med antall feiltrykk på tallet 3 , og handle bevisst var også negativt korrelert med antall manglende trykk. Det var ikke lenger signifikant korrelasjon mellom ikkedømme og prestasjonsvariablene på SART.

Analysene av ACT (tabell 2) viste at ikke-dømme-fasetten var negativt korrelert med sensitivitet $\left(d^{\prime}\right)$ og gjennomsnittlig reaksjonstid i alle settinger, bortsett fra på distanse 3 (rød sirkel dukket opp lengst vekk fra målet) og i setting o (ingen rød sirkel som distraherte). Videre fant vi at når den røde sirkelen var til hjelp (på samme posisjon som målet), var observere og ikke-reagere positivt korrelert med sensitivitet ( $\left.d^{\prime}\right)$.

Tabell 1. Gjennomsnittlige scorer og korrelasjoner ( $r$ ) mellom de fem mindfulness-fasettene.

\begin{tabular}{|l|c|c|c|c|c|c|}
\hline & $\begin{array}{c}\text { Gjennomsnitt } \\
\text { score }\end{array}$ & Standardavvik & Beskrive & $\begin{array}{c}\text { Handle } \\
\text { bevisst }\end{array}$ & $\begin{array}{c}\text { Ikke- } \\
\text { dømme }\end{array}$ & $\begin{array}{c}\text { Ikke- } \\
\text { reagere }\end{array}$ \\
\hline Score (1-5): & & & & & & \\
\hline Observere & 3.08 & 0.68 & .203 & .147 & -.266 & $.317^{\star}$ \\
\hline Beskrive & 3.52 & 0.63 & & .146 & .120 & .126 \\
\hline Handle bevisst & 3.60 & 0.67 & & & .209 & -.085 \\
\hline Ikke-dømme & 3.59 & 0.71 & & & & -.247 \\
\hline Ikke-reagere & 3.12 & 0.59 & & & & - \\
\hline
\end{tabular}

Note: ${ }^{\star} p<.05$ 
Tabell 2. Gjennomsnittlige scorer og korrelasjoner ( $r$ ) mellom de fem mindfulness-fasettene og prestasjon på ACT.

\begin{tabular}{|l|c|c|c|c|c|c|c|}
\hline & $\begin{array}{l}\text { Gjennom- } \\
\text { snitt score }\end{array}$ & $\begin{array}{c}\text { Standard } \\
\text { avvik }\end{array}$ & Observere & Beskrive & $\begin{array}{c}\text { Handle } \\
\text { bevisst }\end{array}$ & $\begin{array}{c}\text { Ikke- } \\
\text { dømme }\end{array}$ & $\begin{array}{c}\text { Ikke- } \\
\text { reagere }\end{array}$ \\
\hline $\begin{array}{l}d^{\prime} \text { rød sirkel } \\
\text { på målet }\end{array}$ & 2.53 & 1.00 & $.405^{*}$ & .064 & .125 & $-.395^{*}$ & $.430^{* *}$ \\
\hline $\begin{array}{l}d^{\prime} \text { rød sirkel } \\
\text { på distanse 1 }\end{array}$ & 1.83 & 1.00 & .119 & -.010 & .162 & $-.355^{*}$ & .260 \\
\hline $\begin{array}{l}d^{\prime} \text { rød sirkel } \\
\text { på distanse 2 }\end{array}$ & 2.11 & 1.19 & .160 & -.020 & .139 & $-.434^{* *}$ & .136 \\
\hline $\begin{array}{l}d^{\prime} \text { rød sirkel } \\
\text { på distanse 3 }\end{array}$ & 1.93 & 0.89 & .276 & .041 & .118 & $-.398^{*}$ & .264 \\
\hline$d^{\prime}$ baseline & 2.23 & 0.94 & .214 & -.147 & .250 & -.279 & .193 \\
\hline $\begin{array}{l}\text { RT rød sirkel } \\
\text { på målet }\end{array}$ & 710.59 & 117.55 & .201 & .067 & .034 & $-.359^{*}$ & -.151 \\
\hline $\begin{array}{l}\text { RT rød sirkel } \\
\text { på distanse 1 }\end{array}$ & 784.84 & 141.67 & .290 & .068 & .067 & $-.392^{*}$ & .075 \\
\hline $\begin{array}{l}\text { RT rød sirkel } \\
\text { på distanse 2 }\end{array}$ & 782.40 & 153.87 & .269 & .080 & .045 & $-.372^{*}$ & .055 \\
\hline $\begin{array}{l}\text { RT rød sirkel } \\
\text { på distanse 3 }\end{array}$ & 788.12 & 153.36 & .239 & .030 & .036 & -.287 & .086 \\
\hline RT baseline & 748.47 & 141.72 & .222 & .013 & .042 & $-.401^{*}$ & .002 \\
\hline
\end{tabular}

Note: ${ }^{\star} p<.05,{ }^{\star \star} p<.01$.

Tabell 3. Gjennomsnittlige scorer og korrelasjoner ( $r$ ) mellom de fem mindfulness-fasettene og prestasjon på SART.

\begin{tabular}{|l|c|c|c|c|c|c|c|c|c|}
\hline & $\begin{array}{c}\text { Gjen- } \\
\text { nomsnitt } \\
\text { score }\end{array}$ & $\begin{array}{c}\text { Standard } \\
\text { avvik }\end{array}$ & $\begin{array}{c}\text { Manglen- } \\
\text { de trykk } \\
\text { på 1,2 og } \\
\mathbf{4 - 9}\end{array}$ & $\begin{array}{c}\text { RT } \\
\text { Obser- } \\
\text { vere }\end{array}$ & $\begin{array}{c}\text { Be- } \\
\text { skrive }\end{array}$ & $\begin{array}{c}\text { Handle } \\
\text { bevisst }\end{array}$ & $\begin{array}{c}\text { Ikke- } \\
\text { dømme }\end{array}$ & $\begin{array}{c}\text { Ikke- } \\
\text { reagere }\end{array}$ \\
\hline $\begin{array}{l}\text { Antall trykk } \\
\text { på «3» }\end{array}$ & 18.67 & 5.00 & .282 & $-.801^{* *}$ & $-.454^{* *}$ & -.265 & -.280 & $.346^{*}$ & -.243 \\
\hline $\begin{array}{l}\text { Manglende } \\
\text { trykk (unntatt } \\
\ll 3 »)\end{array}$ & 8.81 & 10.32 & - & -.121 & .124 & -.141 & $-.358^{*}$ & .009 & .033 \\
\hline $\begin{array}{l}\text { Reaksjonstid } \\
\text { (unntatt «3») }\end{array}$ & 302.26 & 44.00 & & - & $.324^{*}$ & .281 & .298 & $-.326^{*}$ & $.362^{*}$ \\
\hline
\end{tabular}

Note: ${ }^{\star} p<.05,{ }^{\star \star} p<.01$.

Tabell 4. Partiell korrelasjon mellom de fem mindfulness-fasettene og prestasjon på SART.

\begin{tabular}{|l|c|c|c|c|c|c|}
\hline & $\begin{array}{c}\text { Errors of } \\
\text { omission }\end{array}$ & Observere & Beskrive & $\begin{array}{c}\text { Handle } \\
\text { bevisst }\end{array}$ & $\begin{array}{c}\text { Ikke- } \\
\text { dømme }\end{array}$ & $\begin{array}{c}\text { Ikke- } \\
\text { reagere }\end{array}$ \\
\hline Antall trykk på «3» & .198 & $-.346^{\star}$ & -.063 & -.065 & .146 & .100 \\
\hline $\begin{array}{l}\text { Manglende trykk på } \\
\ll 1,2 \text { og 4-9» }\end{array}$ & - & .204 & -.090 & $-.319^{\star}$ & -.061 & .117 \\
\hline
\end{tabular}

Note: ${ }^{\star} p<.05$ 


\section{Diskusjon}

Hensikten med denne studien var å undersøke sammenhengen mellom mindfulness og objektive markører for inhibisjon hos profesjonelle fotballspillere i Norge. Vi fant delvis støtte for at det å være mindful kan innebære bedret evne til responsinhibisjon, men kun for observerefasetten av mindfulness. Resultatene viste videre at ikke-dømme-fasetten av mindfulness var assosiert med flere feiltrykk på tallet 3, noe de kortere reaksjonstidene knyttet til denne fasetten kan indikere å være forårsaket av en mer impulsiv måte å respondere på (Ishimatsu et al., 2016).

Observere-fasetten av mindfulness innebærer en økt grad av åpenhet til både indre og ytre stimuli (Baer et al., 2006). En mulig forklaring på den positive sammenhengen mellom responsinhibisjon og denne fasetten er derfor at denne åpenheten også innebærer en økt mottagelighet for de korte emosjonelle triggerne som er påvist å rekruttere våre eksekutive funksjoner (Weinberg, Riesel, \& Hajcak, 2012). Om dette henger sammen med bedre proaktiv eller reaktiv kontroll, er usikkert. Proaktiv kontroll fungerer som en «brems» for å sikre riktige responser i usikre situasjoner (Aron, 2011; Sakai, Uchiyama, Shin, Hayashi, \& Sadato, 2013). Reaktiv kontroll innebærer redusert reaksjon på feilhandlinger (Helton, Kern, \& Walker, 2009; Sakai et al., 2013).

Etter at vi kontrollerte for reaksjonstid, var det ikke lenger en negativ sammenheng mellom ikke-dømme og prestasjon på SART, noe som indikerer at denne fasetten er assosiert med en raskere og mer impulsiv respons og ikke responsinhibisjon per se. Dette støttes av at ikke-dømming også var assosiert med kortere reaksjonstider på ACT-testen. Dette var et overraskende funn, siden kortere reaksjonstid på inhibisjonstester har vist seg å henge sammen med impulsivitet (Ishimatsu et al., 2016) og mangel på bevisst tilstedeværelse (Cheyne, Solman, Carriere, \& Smilek, 2009). Det er heller ikke i tråd med mindfulness-teori (Bishop et al., 2004), selv om enkelte har hevdet at det å innta en ikke-dømmende holdning kan komme i veien for tilstedeværelse (Rapgay \& Bystrisky, 2009). Én mulighet er at motivasjonsmessige faktorer har ført til at respondenter ofrer nøyaktigheten for å respondere raskere på inhibisjonstester (Saunders et al., 2015), for eksempel ved at de som scorer høyt på 
ikke-dømme, unnlater å gjøre sitt beste, eller at de ikke tar oppgaven på alvor. Det er verdt å nevne at ikke-dømme-fasetten er et element i mindfulness som oppfattes som noe problematisk å forstå verdien av i idrettsmiljøer (Birrer et al., 2012) og andre høyprestasjonsmiljøer (Meland, Fonne, Wagstaff, \& Pensgaard, 2015). Det er trolig på grunn av en erkjennelse av at en ikke-dømmende holdning ikke alltid er bra. Idrettsutøvere vil nok enkelt kunne se verdien av å forholde seg til virkeligheten og ikke dømme seg selv unødvendig hardt etter en dårlig prestasjon. Samtidig kan de samme utøverne oppleve at en kritisk og dømmende selv-evaluering av egen prestasjon og eget tankesett også kan føre til utvikling (Birrer et al., 2012). Skal man dra nytte av fordelene og unngå ulempene ved å være høy eller lav på en av mindfulness-fasettene, fordrer det åpenbart en fleksibilitet i situasjonen en befinner seg i. Det er derfor viktig å fortsette å kartlegge fordeler og ulemper ved å være høy eller lav på de ulike mindfulness-fasettene i prestasjonsmiljøer.

Vi fant ingen sammenheng mellom mindfulness og prestasjon på ACT der det var en oppmerksomhetsfanger (rød sirkel) involvert. Dette står i motsetning til tidligere studier som har funnet en positiv assosiasjon mellom mindfulness og robusthet overfor visuelle stimuli (Fan, Tang, Tang, \& Posner, 2015; Jha, Krompinger, \& Baime, 2007; Tang et al., 2007). Dette kan skyldes forskjeller i testmetodikk. Tidligere studier har benyttet tester som i stor grad er sensitive for prosesser sent i persepsjonsprosessen. ACT-testen vi benyttet, er spesifikk for den tidlige seleksjonsprosessen av stimuli, som er kjent for å være stabil og vanskeligere å påvirke enn den seleksjonen som foregår senere i persepsjonsprosessen (Theeuwes, 2014). Resultatene av ACT-testen tyder på at mindfulness ikke er assosiert med de tidligere stadiene i persepsjonsprosessen, eller at mindfulness-nivået hos fotballspillerne i denne studien ikke var høyt nok til å påvirke tidlige persepsjonsprosesser. Det siste er i tråd med studier som kun fant sammenheng mellom graden av mindfulness og tidlig persepsjon på mennesker som har drevet målrettet mindfulness-trening i mange år (Chiesa, Serretti, \& Jakobsen, 2013).

Et overraskende funn var den positive sammenhengen mellom mindfulness og sensitiveten til den horisontale/vertikale linjen i ACTtesten i settingen der det røde blinket fungerte som hjelp (samme sted 
som målbildet). Denne sammenhengen omfattet observere- og ikke-reagere-fasettene av mindfulness. Det indikerer at spillere som scorer høyt på disse to fasettene, klarer å utnytte det røde blinket som en hjelp for å respondere fortere og mer presist, uten å bli mer distrahert av det når det opptrer som en distraktor. Det finnes studier som viser at mindfulness-trening kan gi økt perseptuell fleksibilitet (Hodgins \& Adair, 2010). En mulig forklaring på funnet i denne studien er at spillere som scorer høyt på observere og ikke-reagere, oppfatter den røde sirkelen tidligere, noe som gir dem bedre tid til å velge riktig respons. Det er fastslått at mindfulness-trening kan redusere terskelverdien for når en oppfatter stimuli (Jensen, Hansen, Abrahamsson, \& Nørgaard, 2011). Perseptuell fleksibilitet og tidlig oppfattelse av stimuli vil være svært fordelaktig i fotball, der spillere og hendelser endrer seg raskt og skifter mellom å være relevante og irrelevante.

Når det gjelder sammenhengen mellom fasettene observere og ikkereagere i denne studien, kan én forklaring være at en direkte og åpen eksponering (observasjon) for ubehagelige stimuli og indre forstyrrelser av emosjonell karakter over tid fører til redusert aktivering (ikkereaksjon) gjennom tilvenning (Hôlzel et al., 2011). Det er blitt hevdet at denne sammenhengen kan være særlig sterk hos toppidrettsutøvere som rutinemessig utsettes for indre og ytre ubehag (Haase et al., 2015). Dette bør likevel undersøkes nærmere, siden andre studier har funnet en klar distinksjon mellom disse to fasettene i normalbefolkningen (Anicha, Ode, Moeller, \& Robinson, 2012).

Det var også en del ikke-signifikante sammenhenger i denne studien. Vi fant for eksempel ingen forbindelse mellom beskrive-fasetten og prestasjon på PC-testene. En sannsynlig forklaring kan være at evnen til å beskrive egne følelser reflekterer langvarige emosjonelle tilstander, og ikke de korte og kraftige affektive responsene som trigger våre eksekutive funksjoner (Weinberg et al., 2012). Når det gjelder handle bevisst-fasetten, fant vi kun sammenheng med antall manglende trykk på SART. Dette er tidligere blitt assosiert med svikt i konsentrasjon og ikke inhibisjon (Cheyne et al., 2009). En alternativ forklaring kan være at beskrive- og handle bevisst-fasettene av mindfulness måler relativt grove tendenser til å monitorere følelser og det å være på «autopilot» i hverdagen. Dermed vil 
heller ikke dette samsvare med de korte og intense signalene som skal til for å trigge våre eksekutive funksjoner.

En annen mulighet er at testene vi benyttet i studien, mangler den sensitiviteten som skal til for å plukke opp forskjeller i inhibisjon hos spillerne. Dette gjelder særlig SART-testen, som krever en relativt høy grad av inhibisjon for at man skal unngå å trykke på tallet 3. En studie som undersøkte effekter av mindfulness-trening, fant ingen endringer i prestasjon på en inhibisjonstest, men kunne påvise aktivitetsendringer i de områdene av hjernen som er involvert i inhibisjon (Fan et al., 2015). I senere studier kan man derfor vurdere mer sensitive nevropsykologiske mål på inhibisjon enn SART.

\section{Styrker og svakheter}

Bruken av standardiserte tester gjør studien lett å replisere, og gir reliable resultater som er enkle å sammenligne med andre idrettspopulasjoner. Når det er sagt, må en huske at utvalget er lite, og at testene som ble benyttet i denne studien, er designet for å måle inhibisjon - og ikke andre kognitive ferdigheter som også er viktig for prestasjoner innen fotball. SART-testen har vist seg å ha høy validitet utenfor laboratoriet (Verburgh et al., 2014), men en må huske på at PC-tester er annerledes enn fotballspill. De er basert på øye-hånd-koordinasjon og finmotorikk, $\mathrm{i}$ motsetning til på fotballbanen der mye handler om øye-fot koordinasjon og grovmotorikk. Studien følger også et tverrsnittdesign som gjør at vi ikke kan si noe sikkert om årsak og virkning.

\section{Oppsummering og praktiske implikasjoner}

Fotball er full av distraksjoner - der manglende inhibisjon, impulsive handlinger og feil fokusering på banen kan føre til feilpasninger, som igjen fører til forsvarstabber og tapte målsjanser. Denne studien markerer et første trinn i å kartlegge mulige fordeler og ulemper av mindfulness hos profesjonelle fotballspillere på eksekutiv funksjon ved bruk av PCbaserte tester av inhibisjon. Vi fant at høyere nivåer på observere-fasetten av mindfulness var forbundet med bedre responsinhibisjon. Høyere nivåer 
på ikke-dømme-faktoren var forbundet med mer impulsive responser på begge testene. I tillegg fant vi indikasjoner på at observere- og ikke-reagere-fasettene var forbundet med økt perseptuell fleksibilitet. Dette tyder på at når det gjelder ferdigheter som innebærer inhibitorisk kontroll, kan det være både en fordel og en ulempe å være mindful, avhengig av hvilke fasetter av mindfulness som er mest fremtredende. Disse funnene kan være med å utvikle mer målrettede mindfulness-intervensjoner for profesjonelle fotballspillere og idrettsutøvere, der en søker å maksimere fordeler og minimere ulemper. Om fotballspillere har noe å hente på å utvikle sin grad av mindfulness, er fortsatt et åpent spørsmål. Mindfulness-scorene i denne studien var imidlertid på samme nivå som man fant hos norsk militært helikopterpersonell (Meland, Ishimatsu, et al., 2015), men lavere enn hos jagerflypersonell som har deltatt i mindfulness-trening (Meland, Fonne, et al., 2015). Dette tyder på at fotballspillerne fortsatt har mulighet til å øke sin grad av mindfulness. Neste steg vil derfor være å undersøke om resultatene lar seg replisere i andre idrettspopulasjoner, og om deltakelse i mindfulness-trening har effekt på fotballprestasjoner.

\section{Referanser}

Anicha, C.L., Ode, S., Moeller, S.K., og Robinson, M.D. (2012). Toward a cognitive view of trait mindfulness: Distinct cognitive skills predict Its observing and nonreactivity facets. Journal of Personality, 8o(2), 255-285.

Aron, A.R. (2011). From reactive to proactive and selective control: Developing a richer model for stopping inappropriate responses. Biological Psychiatry, 69(12), e55-e68.

Baer, R.A., Smith, G.T., Hopkins, J., Krietemeyer, J., \& Toney, L. (2006). Using SelfReport Assessment Methods to Explore Facets of Mindfulness. Assessment, 13(1), 27-45.

Birrer, D., Rôthlin, P., \& Morgan, G. (2012). Mindfulness to enhance athletic performance: Theoretical considerations and possible impact mechanisms. Mindfulness, 3(3), 235-246.

Bishop, S.R., Lau, M., Shapiro, S., Carlson, L., Anderson, N.D., Carmody, J., ... Velting, D. (2004). Mindfulness: A proposed operational definition. Clinical psychology: Science and practice, 11(3), 230-241.

Brown, K.W., Ryan, R.M. \& Creswell, J.D. (2007). Mindfulness: Theoretical foundations and evidence for its salutary effects. Psychological Inquiry, 18(4), 211-237. 
Cheyne, J.A., Carriere, J.S.A., \& Smilek, D. (2006). Absent-mindedness: Lapses of conscious awareness and everyday cognitive failures. Consciousness and Cognition, 15(3), 578-592.

Cheyne, J.A., Solman, G.J.F., Carriere, J.S.A., \& Smilek, D. (2009). Anatomy of an error: A bidirectional state model of task engagement/disengagement and attention-related errors. Cognition, 111(1), 98-113.

Chiesa, A., Serretti, A., \& Jakobsen, J.C. (2013). Mindfulness: Top-down or bottomup emotion regulation strategy? Clinical Psychology Review, 33(1), 82-96.

Coutts, A.J. (2016). Fatigue in football: It's not a brainless task! Journal of sports sciences, 1-1.

Dundas, I., Vøllestad, J., Binder, P.E., \& Sivertsen, B. (2013). The five factor mindfulness questionnaire in Norway. Scandinavian Journal of Psychology, 54(3), 250-260.

Fan, Y., Tang, Y.Y., Tang, R., \& Posner, M. (2015). Time course of conflict processing modulated by brief meditation training. Frontiers in Psychology, 6, 1-6.

Gallant, S.N. (2016). Mindfulness meditation practice and executive functioning: Breaking down the benefit. Consciousness and Cognition, 40, 116-130.

Haase, L., May, A.C., Falahpour, M., Isakovic, S., Simmons, A.N., Hickman, S., ... Paulus, M.P. (2015). A pilot study investigating changes in neural processing after mindfulness training in elite athletes. Frontiers in Behavioral Neuroscience, 9, 229.

Helton, W.S. (2009). Impulsive responding and the sustained attention to response task. Journal of Clinical and Experimental Neuropsychology, 31(1), 39-47.

Helton, W.S., Kern, R.P., \& Walker, D.R. (2009). Conscious thought and the sustained attention to response task. Consciousness and Cognition, 18(3), 600-607.

Hodgins, H.S. \& Adair, K.C. (2010). Attentional processes and meditation. Consciousness and Cognition, 19(4), 872-878.

Hölzel, B.K., Lazar, S.W., Gard, T., Schuman-Olivier, Z., Vago, D.R., \& Ott, U. (2011). How Does Mindfulness Meditation Work? Proposing Mechanisms of Action From a Conceptual and Neural Perspective. Perspectives on Psychological Science, 6(6), 537-559.

Huijgen, B.C.H., Leemhuis, S., Kok, N.M., Verburgh, L., Oosterlaan, J., ElferinkGemser, M.T., \& Visscher, C. (2015). Cognitive Functions in Elite and Sub-Elite Youth Soccer Players Aged 13 to 17 Years. PLoS ONE, 10(12), eo14458o.

Ishimatsu, K., Meland, A., Hansen, T.A., Kåsin, J.I., \& Wagstaff, A.S. (2016). Action slips during whole-body vibration. Applied ergonomics, 55, 241-247.

Jensen, M.A., Hansen, A.M., Abrahamsson, P., \& Nørgaard, A.W. (2011).

Development and evaluation of a liquid chromatography tandem mass spectrometry method for simultaneous determination of salivary melatonin, cortisol and testosterone. Journal of Chromatography B, 879(25), 2527-2532. 
Jha, A.P., Krompinger, J., \& Baime, M. (2007). Mindfulness training modifies subsystems of attention. Cognitive, Affective, \& Behavioral Neuroscience, 7(2), 109-119.

Jha, A.P., Morrison, A.B., Dainer-Best, J., Parker, S., Rostrup, N., \& Stanley, E.A. (2015). Minds At Attention: Mindfulness Training Curbs Attentional Lapses in Military Cohorts. PLOS ONE, 10(2), eo116889.

Jha, A.P., Morrison, A.B., Parker, S.C., \& Stanley, E.A. (2017). Practice is protective: mindfulness training promotes cognitive resilience in high-stress cohorts. Mindfulness, 8(1), 46-58.

Josefsson, T. \& Broberg, A. (2010). Meditators and non-meditators on sustained and executive attentional performance. Mental Health, Religion \& Culture, 14(3), 291-309.

Larson, M.J., Steffen, P.R., \& Primosch, M. (2013). The impact of a brief mindfulness meditation intervention on cognitive control and error-related performance monitoring. Frontiers in Human Neuroscience, 7, 308.

MacCoon, D.G., MacLean, K.A., Davidson, R.J., Saron, C.D., \& Lutz, A. (2014). No Sustained Attention Differences in a Longitudinal Randomized Trial Comparing Mindfulness Based Stress Reduction versus Active Control. PLoS ONE, 9(6), e97551.

Meland, A., Fonne, V., Wagstaff, A., \& Pensgaard, A.M. (2015). Mindfulness-based mental training in a high-performance combat aviation population: A one-year intervention study and two-year follow-up. The International Journal of Aviation Psychology, 25(1), 48-61.

Meland, A., Ishimatsu, K., Pensgaard, A.M., Wagstaff, A., Fonne, V., Garde, A.H., \& Harris, A. (2015). Impact of Mindfulness Training on Physiological Measures of Stress and Objective Measures of Attention Control in a Military Helicopter Unit. The International Journal of Aviation Psychology, 25(3-4), 191-208.

Miyake, A., \& Friedman, N.P. (2012). The nature and organization of individual differences in executive functions four general conclusions. Current Directions in Psychological Science, 21(1), 8-14.

Nunnally, J.C. \& Bernstein, I.H. (1994). The theory of measurement error. Psychometric theory, 209-247.

Rapgay, L. \& Bystrisky, A. (2009). Classical mindfulness. Annals of the New York Academy of Sciences, 1172(1), 148-162.

Robertson, I.H., Manly, T., Andrade, J., Baddeley, B.T., \& Yiend, J. (1997). 'Oops!': Performance correlates of everyday attentional failures in traumatic brain injured and normal subjects. Neuropsychologia, 35(6), 747-758.

Röthlin, P., Horvath, S., Birrer, D., \& Grosse Holtforth, M. (2016). Mindfulness promotes the ability to deliver performance in highly demanding situations. Mindfulness, 7(3), 727-733. 
Sahdra, B.K., MacLean, K.A., Ferrer, E., Shaver, P.R., Rosenberg, E.L., Jacobs, T.L., ... Bridwell, D.A. (2011). Enhanced response inhibition during intensive meditation training predicts improvements in self-reported adaptive socioemotional functioning. Emotion, 11(2), 299.

Sakai, H., Uchiyama, Y., Shin, D., Hayashi, M.J., \& Sadato, N. (2013). Neural Activity Changes Associated with Impulsive Responding in the Sustained Attention to Response Task. PLoS ONE, 8(6), e67391.

Sappington, R., \& Longshore, K. (2015). Systematically Reviewing the Efficacy of Mindfulness-Based Interventions for Enhanced Athletic Performance. Journal of Clinical Sport Psychology, 9(3).

Saunders, B., Rodrigo, A.H., \& Inzlicht, M. (2015). Mindful awareness of feelings increases neural performance monitoring. Cognitive, Affective, \& Behavioral Neuroscience, 1-13.

Schmertz, S., Anderson, P., \& Robins, D. (2009). The Relation Between Self-Report Mindfulness and Performance on Tasks of Sustained Attention. Journal of Psychopathology and Behavioral Assessment, 31(1), 60-66.

Stanislaw, H. \& Todorov, N. (1999). Calculation of signal detection theory measures. Behavior Research Methods, Instruments, \& Computers, 31(1), 137-149.

Tang, Y.Y., Holzel, B.K., \& Posner, M.I. (2015). The neuroscience of mindfulness meditation. Nat Rev Neurosci, 16(4), 213-225.

Tang, Y.Y., Ma, Y., Wang, J., Fan, Y., Feng, S., Lu, Q., .. Posner, M.I. (2007). Shortterm meditation training improves attention and self-regulation. Proceedings of the National Academy of Sciences, 104(43), 17152-17156.

Teper, R., Segal, Z.V., \& Inzlicht, M. (2013). Inside the Mindful Mind: How Mindfulness Enhances Emotion Regulation Through Improvements in Executive Control. Current Directions in Psychological Science, 22(6), 449-454.

Theeuwes, J. (2014). Spatial Orienting and Attentional Capture. I A.C. Nobre \& S. Kastner (red.), (s. 231-252). Oxford: Oxford University Press.

Theeuwes, J. \& Chen, C. (2005). Attentional capture and inhibition (of return): The effect on perceptual sensitivity. Attention, Perception, \& Psychophysics, 67(8), 1305-1312.

Verbruggen, F. \& Logan, G.D. (2008). Response inhibition in the stop-signal paradigm. Trends in Cognitive Sciences, 12(11), 418-424.

Verburgh, L., Scherder, E.J., van Lange, P.A. \& Oosterlaan, J. (2014). Executive functioning in highly talented soccer players. PLoS ONE, 9(3), e91254.

Vestberg, T., Gustafson, R., Maurex, L., Ingvar, M. \& Petrovic, P. (2012). Executive functions predict the success of top-soccer players. PLoS ONE, 7(4), e34731.

Voss, M.W., Kramer, A.F., Basak, C., Prakash, R.S., \& Roberts, B. (2010). Are expert athletes 'Expert' in the cognitive laboratory? A meta-analytic review of cognition and sport expertise. Applied Cognitive Psychology, 24(6), 812-826. 
Weinberg, A., Riesel, A., \& Hajcak, G. (2012). Integrating multiple perspectives on error-related brain activity: The ERN as a neural indicator of trait defensive reactivity. Motivation and Emotion, 36(1), 84-100.

Wilson, K.M., Russell, P.N., \& Helton, W.S. (2015). Spider stimuli improve response inhibition. Consciousness and Cognition, 33, 406-413. 


\title{
Når dommeren i fotball dømmer feil ...
}

\section{En videobasert analyse av straffesparksituasjoner i Tippeligaen der norske toppdommere og toppspillere har vurdert at dommerens avgjørelse er feil}

\author{
Bjørn Tore Johansen ${ }^{\star}$ \& Martin K. Erikstad \\ Universitetet i Agder, Fakultet for helse- og idrettsvitenskap
}

\begin{abstract}
Sammendrag: Målet med denne studien var å undersøke hva som kjennetegner situasjoner hvor toppdommere i fotball dømmer feil. To ekspertpanel, bestående av henholdsvis fire toppdommere og fire toppspillere, vurderte 98 potensielle straffesparksituasjoner i Tippeligaen. Situasjonene der samtlige i ekspertpanelene vurderte at kampdommeren tok en feil avgjørelse $(N=14)$, ble deretter analysert med bakgrunn i anbefalte dommertekniske kriterier og retningslinjer - som dommerens avstand, vinkel og innsikt til disse straffesparksituasjonene. Resultatene viste at i 11 av disse 14 situasjonene hadde dommeren større avstand enn det som er anbefalt. Videre var både vinkel og innsikt kun av middels eller dårlig karakter. Dette kan indikere at en riktig utgangsposisjon kan bidra til å forklare hvorfor dommeren tar en feil avgjørelse. Funn viste også at dommerfeil var mer sannsynlig å gå i favør av lag med høy status, og blir i artikkelen diskutert i lys av teori om håndtering av feil og sosialt press.
\end{abstract}

Nøkkelord: fotballdommer, straffespark, ekspertpanel, feildømming

\begin{abstract}
The aim of this study was to investigate characteristics of situations when top referees in soccer make an incorrect decision. Two expert panels, consisting of four top referees and four top players respectively, assessed 98 potential penalty shootout situations in Tippeligaen (Norwegian Premier League). The situations in which all the expert panels considered that the match referee made an incorrect decision $(N=14)$ were then analyzed based on recommended technical refereeing criteria and guidelines, as the referee's distance to, angle to and insight into these penalty situations. The results revealed that in 11 of these 14 situations the referee had a greater distance than recommended. Furthermore, both the angle and insight were only of medium or poor nature. This may indicate that the referee had limited basis when assessing these situations, and subsequently landed on a wrong decision. Findings also showed that referees were more likely to go in favor of high status teams. This will be a topic for discussion in this article, based on the theory of dealing with mistakes and social pressure.
\end{abstract}

Keywords: soccer referee, penalty kick, expert panel, incorrect refereeing

\footnotetext{
${ }^{\star}$ Korresponderende forfatter: Bjørn Tore Johansen, ph.d., Fakultet for helse- og idrettsvitenskap, Universitetet i Agder, Postboks 422, 4604 Kristiansand. E-post: bjorn.t.johansen@uia.no, telefon: +47 38141295

Sitering av denne artikkelen: Johansen, B.T. \& Erikstad, M.K. (2018). Når dommeren i fotball dømmer feil ... En videobasert analyse av straffesparksituasjoner i Tippeligaen der norske toppdommere og toppspillere har vurdert at dommerens avgjørelse er feil. I T. Haugen \& R. Høigaard (red). Trender $i$ idrettspsykologisk forskning i Skandinavia (Kap. 10, s. 205-224). Oslo: Cappelen Damm Akademisk. DOI: https://doi. org/10.23865/noasp.39.ch1o

Lisens CC-BY 4.0
} 


\section{Innledning}

Hvor vanskelig kan det egentlig være for en dommer å dømme et korrekt straffespark i fotball? Reglene og retningslinjene er klare når det gjelder å måtte ta en slik avgjørelse. I spillereglene til Norges Fotballforbund (NFF) heter det (regel 14) blant annet: «Straffespark dømmes mot et lag som innenfor eget straffesparkfelt begår en forseelse som medfører at et direkte frispark tildeles motstanderlaget» (NFF, 2016, s. 93). Alle autoriserte dommere i fotball må dokumentere kjennskap til regelverket, og at de oppfyller kravene som stilles til hurtighet og utholdenhet (NFF, 2017; UEFA, 2017). A mestre de fysiske kravene er en forutsetning for at en dommer er riktig plassert i ulike situasjoner som han eller hun må vurdere for videre å kunne fatte en mest mulig korrekt avgjørelse (Helsen \& Bultynck, 2004; Johansen \& Haugen, 2013). I de senere årene har kravene som stilles til toppdommere i fotball, økt betydelig (se Mascarenhas, Button, O'Hare, \& Dicks, 2009; Mascarenhas, O’Hare, \& Plessner, 2006; Samuel, 2015; Voight, 2009). De aller fleste aktørene i toppfotballen krever at en dommer skal gjøre en topp prestasjon uten feildømming (Slack, Maynard, Butt, \& Olusoga, 2013), og toppdommere i dag er helt avhengig å mestre ulike kilder til press og stress for å lykkes i dommerrollen (Samuel, 2015; Wolfson \& Neave, 2007).

Voight (2009) fant blant fotballdommere i USA at de to mest oppgitte kildene til stress forbundet med en avgjørelse var 1) å ta en kontroversiell avgjørelse og 2) å ta en feil avgjørelse. Ifølge Voight (2009) var feildømt straffespark og en gal avgjørelse i forbindelse med å gi rødt kort noe av det vanskeligste i dommerrollen - og kanskje de største kildene til økt stressnivå. I tillegg identifiserte han en annen viktig kilde til utvikling av stress blant dommere, nemlig det å være feilplassert når en viktig avgjørelse skulle fattes. Skal en dommer kunne dømme mest mulig korrekt, må han eller hun til enhver tid søke å ha riktig avstand, vinkel og innsikt til de ulike spillsituasjonene (FA, 2017; NFF, 2017; UEFA, 2017). Når det gjelder avstand, benyttes det en standard som sier at en dommer aldri bør være mer enn tjue meter fra spillet (FA, 2017). En større avstand vil nemlig øke faren for å gå glipp av viktig informasjon som grunnlag for å ta en avgjørelse. En annen viktig faktor for dommeren er at han eller 
hun skaffer seg best mulig vinkel til spillet, og en dommer skal derfor i hovedsak bevege seg i en tenkt diagonal linje på banen (NFF, 2017). En slik bevegelse vil i større grad sikre at en dommer oftere kommer mer vinkelrett på spillet og dermed skaffer seg bedre innsikt i en situasjon. Mallo, Gonzales Frutos, Juárez og Navarro (2012) undersøkte dommeres plassering på banen og fant at avstanden fra dommeren til selve hendelsen påvirket kvaliteten på avgjørelsen: For stor avstand økte faren for å gå glipp av viktig informasjon, mens det å være for nær hendelsen økte faren for å miste oversikten i situasjonen. Mallo et al. (2012) påpeker derfor at en kort, men hensiktsmessig avstand hos dommere vil sørge for at de får mer innsikt til en situasjon, og sannsynligheten for å ta en mest mulig korrekt avgjørelse vil øke.

I profesjonell fotball scores det vanligvis i snitt 2,5 mål fordelt på begge lag, og når sannsynligheten for å score på et straffespark er cirka 80\% (Bar-Eli, Azar, Ritov, Keidar-Levin, \& Schein, 2007), er det rimelig å anta at dommerens avgjørelse i forbindelse med et potensielt straffespark faktisk kan være med å avgjøre kamper. Det er ofte små marginer som avgjør tabellposisjonen, og Baldwin (2008) understreker at dommerens beslutninger vil kunne være helt avgjørende for et lags muligheter til å vinne kampen, ta seriemesterskapet, eller unngå nedrykk. I toppfotballen kreves det at en dommer skal gjøre en topp prestasjon uten feildømming (Samuel, 2015). Det har imidlertid lenge vært anerkjent at dommeren kan gjøre feil, og dette er blitt ansett som en del av fotballens sjarm (Poolton, Siu, \& Masters, 2011). I en kampsituasjon må dommeren fatte en umiddelbar beslutning, og det er hans eller hennes subjektive fortolkning av situasjonen som ligger til grunn for avgjørelsen (Plessner, Schweizer, Brand, \& O'Hare, 2009). I motsetning til spillerne, som er styrt av blant annet lagets taktikk, forklarer Plessner og Betsch (2001) at dommerne tar sine beslutninger basert på intuisjon - da tiden blir for knapp til å gjennomføre en krevende beslutningsprosess.

Når dommerens grunnleggende oppgave er å være den nøytrale part, skal feil som eventuelt begås, ha like stor sannsynlighet for å gagne det ene laget som det andre. Det foreligger imidlertid dokumentasjon på at dommeren ikke alltid klarer å holde seg upartisk (Dohmen, 20o8; Nevill, Balmer \& Williams, 2002; Sutter og Kocher, 2004; Wolfson, Wakelin, 
\& Lewis, 2005). For eksempel så Sutter og Kocher (2004) på fordelingen av straffespark mellom hjemme- og bortelag i den tyske Bundesligaen i 2000/2001. Resultatet viser at hjemmelagene fikk $81 \%$ av straffene de hadde krav på etter kampobservatørens (nøytral og forbundsoppnevnt) rapport, mens andelen for bortelagene kun var på 51\%. At dommeren dømmer i favør av hjemmelagene, og at ytre press fra spillere, publikum og trenere er faktorer som kan være med på å forklare avgjørelsene, er dokumentert i ulike studier (Boyko, Boyko, \& Boyko, 2007; Goumas, 2014; Jamieson, 2010; Johnston, 2008; Wolfson et al., 2005). Wolfson og Neave (2007) hevder at fotballdommere kan forvente seg verbalt angrep eller uenighet fra publikum, trenere og spillere. Det er dermed grunnlag for å tro at disse aktørene har en overbevisning om at de ved å reagere og protestere vil kunne klare å påvirke at fremtidige avgjørelser hos dommeren skal gå i favør av dem eller deres lag.

Haselton og Buss (2000) viser til teorien om feilhåndtering (Error Management Theory, EMT) og hevder at for avgjørelser som tas under usikkerhet, og der konsekvensene av en feil er ujevne, vil avgjørelsen bli tatt ut fra det alternativet som skaper minst negative konsekvenser (Haselton \& Nettle, 2006). Poolton et al. (2011) kunne vise til at dommere som har en høy tendens til å dvele ved sine avgjørelser, ofte tar dem i favør av hjemmelaget, mens dommere som virker bestemte og presise, ikke viser en slik favorisering. De foreslår at funnene kan bli forklart ved at responsen fra tilskuerne gjør at avgjørelsen oppleves som mindre skadelig. Om det er en dommers usikkerhet og tvil som ligger til grunn når en vedkommende dømmer feil, enten ved å tildele et lag straffespark eller å la være i henhold til gjeldende regelverk i en straffesparksituasjon, er etter det vi kjenner til - ennå ikke dokumentert og bør derfor undersøkes nærmere. Denne studien tar sikte på å kartlegge kjennetegn ved straffesparksituasjoner der dommere har tatt en feil avgjørelse.

Når en dommer vurderer en situasjon feil, kan dette skyldes at han eller hun blir påvirket eller føler et sosialt press i forbindelse med det å måtte ta en avgjørelse (Weinberg \& Gould, 2007). Di Corrado, Pellarin og Agostini (2011) definerer sosialt press som et fenomen der både individers og gruppers mentale prosesser, følelser, avgjørelser og oppførsel modifiseres i nærvær av andre betydningsfulle individer og grupper. Mucchi Faina 
(1996) hevder at den viktigste formen for sosial påvirkning er konformitet til flertallet. Denne påvirkningen blir bestemt av faktorer som sosial status, profesjonell suksess, renommé, utdanning, intelligens og kunnskap. Den effekten andre personer har på et individ, er spesifisert i Latanés' (1981) Social Impact Theory (SIT). Teorien til Latané (1981) fremhever at når andre mennesker er kilden til innflytelse, og når individet er målet, vil innflytelsen være en multiplikativ funksjon av styrke, umiddelbarhet og antall andre personer. På bakgrunn av dette kan fotballspillere ha et potensial for å utgjøre en signifikant kilde til innflytelse på dommeren, og da særlig spillere med høy status på lag med høy status. Erikstad (2013) fant i sin studie at lag med høy status hadde en tendens til å bli favorisert av dommeren i tildeling av straffespark i Tippeligaen (kalt Eliteserien fra og med sesongen 2017) da han lot et ekspertpanel bestående av fire toppdommere vurdere straffesparksituasjoner og hva som faktisk ble dømt i de ulike kampene. Han fant at det var lag med høy status som dro mest nytte av dommerfeil i straffesituasjoner, ved at disse lagene fikk flere straffer tildelt, og færre straffer mot seg, enn det et ekspertpanel mente de skulle hatt gjennom en hel sesong.

Formålet med denne studien er å undersøke hva som kjennetegner straffesparksituasjoner der toppdommere i fotball dømmer feil. Det vil bli undersøkt om plasseringen dommeren har hatt i de ulike situasjonene, har sikret en hensiktsmessig avstand og en god vinkel - og dermed en god innsikt til hendelsen. Dette er viktige kriterier for å kunne fatte en mest mulig korrekt avgjørelse (FA, 2017; NFF, 2017; UEFA, 2017). Da det er rimelig å anta at dommeren har opplevd disse situasjonene som tvetydige, og følgelig måtte ta en avgjørelse under tvil og usikkerhet, vil det i lys av EMT og teori på sosialt press bli undersøkt hvilke lag som dro nytte av dommerfeilene.

\section{Metode}

I denne studien ble 98 potensielle straffesparksituasjoner fra Tippeligaen sesongen 2012 undersøkt for å sammenligne kampdommers avgjørelse med hvordan to uavhengige ekspertpanel vurderte situasjonene. Disse straffesparksituasjonene er tidligere blitt vurdert av et ekspertpanel 
bestående av fire toppdommere fra Tippeligaen i en studie utført av Erikstad (2013). Fire Tippeliga-spillere ble kontaktet via e-post og samtykket i å delta (gjennomsnittsalder $=27,25$ år; gjennomsnittserfaring i $\mathrm{TL}=8$ år). Spillerne kommer fra to ulike klubber og bekler ulike posisjoner på banen. For å få en oversikt over og et grunnlag for hovedanalysen ble dataene fra spillernes vurderinger av de 98 straffesparksituasjonene organisert ved å bruke IBM SPSS Statistics 23. Den foreliggende studien er godkjent av Norsk senter for forskningsdata (NSD).

\section{Prosedyre og gjennomføring}

For å identifisere potensielle straffesituasjoner brukte Erikstad (2013) objektive rapporter fra kampene (240) i Tippeligaen sesongen 2012. Disse ble hentet fra TV2 Sumo, VG Live og Nettavisen Live. Dette er tjenester som leverer kamprapporter til en nasjonal populasjon, og har dermed som føring å være objektiv. Dersom kamprapportene beskrev en situasjon der dommeren måtte ta en avgjørelse om å tildele / ikke tildele et straffespark, ble situasjonen inkludert. På bakgrunn av disse kamprapportene forelå det 103 potensielle straffesparksituasjoner i alle kampene for sesongen 2012, men på grunn av manglende billedkvalitet og tilgjengelighet valgte man å bruke 98 av disse. Prosedyren for ekspertpanelet med spillerne i denne studien var lik prosedyren for ekspertpanelet med dommere i studien til Erikstad (2013).

Tilgjengelige videoklipp fra de potensielle straffesituasjonene som var inkludert, ble samlet og redigert ved hjelp av programvaren Camtasia Studio (Tech Smith). For å redusere mulighetene for at spillerne i ekspertpanelet skulle bli påvirket, var klippene, i likhet med Plessner \& Betsch (2001), stoppet før det var mulig å identifisere avgjørelsen som faktisk ble tatt. Lyd ble dempet, tid og resultatet ble skjult, og de ulike situasjonene ble vist fra forskjellige vinkler i både rask og sakte film, samt med zoom. Klippene ble randomisert og nummerert fra 1 til 98. Respondentene hadde mulighet til å spole frem og tilbake så mange ganger som de ønsket, for å sikre at de skulle kunne bedømme klippet så korrekt som mulig. Videoen hadde en total lengde på 37 minutter og 22 sekunder, og den består av 98 straffesituasjoner. 


\section{Distribusjon og evaluering}

En USB-penn og en DVD (back-up) med de 98 situasjonene ble sendt ut til de aktuelle spillerne i tidsrommet august-september 2014. Sammen med videofilene fikk spillerne et infoskriv og et spørreskjema der de registrerte sin vurdering av de ulike situasjonene, samt en instruksjon om hvordan de skulle fylle ut skjemaet. Den første siden av infoskrivet informerte spillerne om studiens formål, at det var frivillig å delta, og at de hadde mulighet til å trekke seg om det var ønskelig, uten å måtte oppgi grunn. Spørreskjemaet bestod av 98 like figurer (se figur 1), nummerert 1-98.

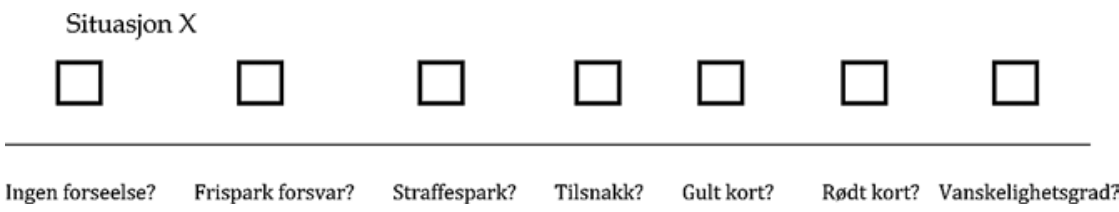

Figur 1. Svarkategorier som ekspertpanelet skulle benytte til hvert enkelt klipp.

Deltakerne i panelet kunne etter eget ønske pause, spole frem og tilbake og se situasjonene så mange ganger de ville. Deretter skulle de krysse av i den eller de boksene de mente var korrekte. I tillegg til å bedømme selve forseelsen måtte spillerne kategorisere hvor komplisert klippet var å bedømme, med tallene 1 (lett), 2 (middels) eller 3 (vanskelig).

Om de derimot følte at et klipp ikke ga tilstrekkelig med informasjon til å ta en avgjørelse, ble de bedt om å krysse ut den aktuelle situasjonen fra arket. Dersom noen av spillerne selv var involvert i noen av situasjonene, ble de bedt om å evaluere dem på samme måte som de resterende klippene. De fire spillerne som ble kontaktet, returnerte alle sine spørreskjemaer i god tid før årsskiftet 2014/2015.

\section{Utvelgelse av situasjoner}

For å kunne karakterisere hva som kjennetegner straffesparksituasjoner der dommer mest sannsynlig dømmer feil, ble situasjoner der samtlige deltakere i de to ekspertpanelene var uenige med det som faktisk ble dømt, undersøkt nærmere. Et utvalg på 14 videoklipp som representerte 
situasjoner der dommeren sannsynligvis burde tatt en annen avgjørelse, ble da det endelige datagrunnlaget.

\section{Analyse av data}

En videobasert analyse av de 14 utvalgte straffesparksituasjonene ble gjennomført med bakgrunn i nasjonale og internasjonale dommertekniske variabler knyttet til dommerens plassering og bevegelse (NFF, 2017; UEFA, 2017; FA, 2017). Det ble registrert om situasjonene oppstod i etablert spill, i kontring eller i faste situasjoner (f.eks. frispark, hjørnespark, innkast). Avstanden dommeren hadde til straffesparksituasjonen, ble estimert ut ifra hva videobildene viser av dommerens plassering $\mathrm{i}$ forhold til ulike markeringer på fotballbanen. Den ble videre kategorisert som kort (o-10 meter), middels (10-20 meter) eller stor (over 20 meter). Avstanden til situasjonen ble tematisk delt inn i kategoriene liten, middels eller stor, mens innsikt og vinkel i de ulike situasjonene ble tematisk delt inn i kategoriene god, middels eller dårlig. Videre ble antall spillere som var involvert i situasjonen, registrert, og situasjonens lokalisering i straffefeltet ble kodet som grønn, gul eller rød (se figur 2).

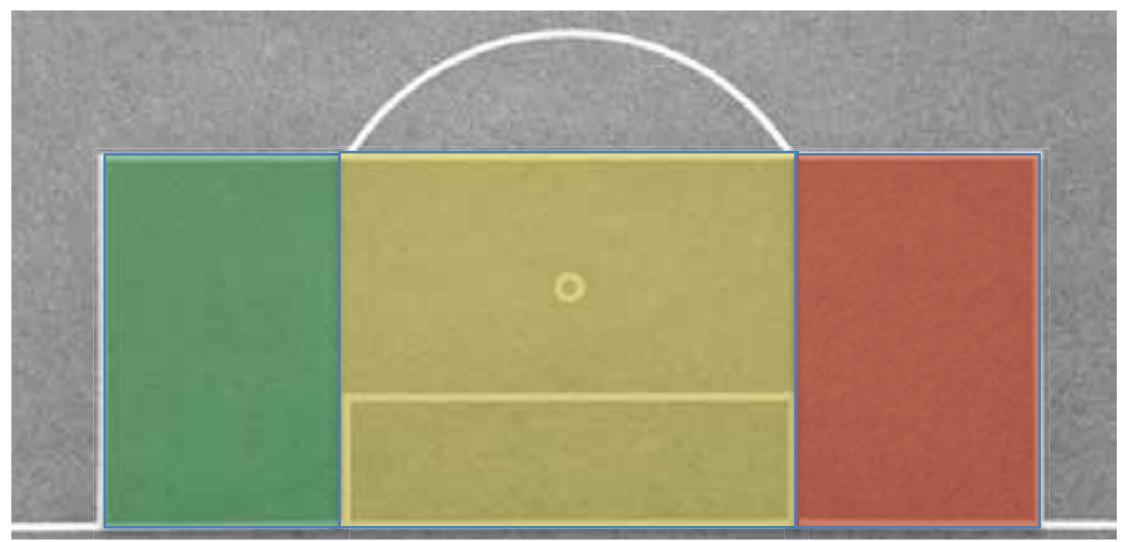

Figur 2. Straffesparkfeltet i fotball med dommerteknisk inndeling i grønn, gul og rød sone, der grønn sone er nærmest assistentdommer. 
Organiseringen og kategoriseringen $i$ analysen av de ulike videoklippene ble utført i samsvar med retningslinjene for en tematisk analyse (Braun \& Clarke, 2006). Et overordnet mål i en tematisk analyse er at temaene som er operasjonalisert i de ulike kategoriene, er sterkt tilknyttet datamaterialet (Braun, Clarke, \& Weate, 2016), i dette tilfellet de ulike videoklippene. Analysen av videoklippene ble utført av to uavhengige personer, hvorav den ene har forskerkompetanse på fagfeltet, mens den andre har dommerfaglig kompetanse (aktiv på nest høyeste nivå i Norge). Dette var anbefalt for å oppnå best mulig validitet i studien (Thomas, Nelson, \& Silverman, 2015). Samsvaret mellom de to ekspertene i den tematiske analysen av de ulike situasjonene var på 98\%, noe som anses å være svært høyt (Pearce, Arnold, Phillips, \& Dwan, 2010).

Videre inkluderte analysen hvilken vanskelighetsgrad ( 1 = lett, 2 = middels, 3 = vanskelig) de to panelene hadde vurdert disse 14 situasjonene til. Analysen tok også for seg hvilken type forseelse som var involvert i straffesparksituasjon (dytt, felling, hands). Ut fra sportslige resultater de to siste sesongene, tilskuerantall og budsjett ble lagene delt inn i tre statuskategorier (høy, middels, lav), i tråd med Erikstad (2013). Det ble så undersøkt hvilken status lag som dro fordel av dommerfeilene, hadde.

\section{Resultater}

\section{Kjennetegn ved straffesparksituasjoner der dommeren dømmer feil}

Tabell 1 viser at 11 av 14 straffesparksituasjoner inntreffer etter etablert spill, mens bare to og én inntreffer etter henholdsvis overgang/kontring eller en fast situasjon, i dette tilfellet et frispark. I åtte av de 14 analyserte situasjonene vurderes dommeren til å ha middels avstand (10-20 meter), mens avstanden vurderes til stor i fire tilfeller og kort i to tilfeller. Når det gjelder dommerens vinkel til straffesparksituasjonene, var fordelingen tre med god vinkel, fem med middels vinkel og seks med dårlig vinkel til situasjonen. Fordelingen i kategorien sikt/innsikt til straffesparksituasjonen var god i tre tilfeller, middels i tre og dårlig i hele åtte tilfeller. Antall spillere som var involvert i selve straffesparkforseelsen, var to i 11 situasjoner og 
Tabell 1. Kjennetegn ved straffesparksituasjoner der alle i ekspertpanelet har ment at kampdommeren har dømt feil.

\begin{tabular}{|c|c|c|c|c|c|c|c|c|c|c|}
\hline \multirow[b]{2}{*}{ Klipnr } & \multicolumn{3}{|c|}{ Spillets syntaks } & \multicolumn{5}{|c|}{ Dommerens forutsetninger } & \multirow{2}{*}{$\begin{array}{l}\text { Vans. } \\
\text { grad }\end{array}$} & \multirow[b]{2}{*}{$\begin{array}{c}\text { Forse- } \\
\text { else }\end{array}$} \\
\hline & $\begin{array}{l}\text { Eta } \\
\text { spil }\end{array}$ & Overgang & $\begin{array}{l}\text { Fast } \\
\text { situ }\end{array}$ & Avstand & Vinkel & $\begin{array}{l}\text { Sikt/ } \\
\text { Innsi }\end{array}$ & $\begin{array}{c}\text { Spi } \\
\text { invol }\end{array}$ & Sone & & \\
\hline 8 & $x$ & & & Middels & Dårlig & Middels & 2 & Grønn & 1,25 & Dytt \\
\hline 13 & $x$ & & & Middels & Middels & Middels & 2 & Gul & 2,75 & Dytt \\
\hline 14 & & & $x$ & Kort & Middels & Middels & 2 & Gul & 2,00 & Felling \\
\hline 18 & $\mathbf{x}$ & & & Stor & Dårlig & Dårlig & 2 & Rød & 1,75 & Felling \\
\hline 21 & & $x$ & & Stor & Dårlig & Dårlig & 2 & Gul & 2,00 & Felling \\
\hline 24 & $x$ & & & Middels & God & God & 2 & Grønn & 1,50 & Felling \\
\hline 27 & $\mathbf{x}$ & & & Stor & Dårlig & Dårlig & 3 & Rød & 2,00 & Felling \\
\hline 68 & $x$ & & & Kort & God & Dårlig & 2 & Gul & 1,75 & Felling \\
\hline 84 & $x$ & & & Middels & Middels & Dårlig & 2 & Grønn & 2,00 & Felling \\
\hline 86 & $x$ & & & Stor & Dårlig & Dårlig & 2 & Rød & 1,75 & Felling \\
\hline 90 & $\mathbf{x}$ & & & Middels & Middels & God & 3 & Grønn & 2,00 & Felling \\
\hline 12 & & $x$ & & Middels & Dårlig & Dårlig & 3 & Rød & 1,50 & Felling \\
\hline 47 & $x$ & & & Middels & God & God & 2 & Gul & 1,50 & Hands \\
\hline 88 & $x$ & & & Middels & Middels & Dårlig & 2 & Rød & 1,25 & Dytt \\
\hline
\end{tabular}

Note. I de 11 øverste situasjonene er det ikke blitt dømt straffespark, men i de tre nederste er det blitt dømt straffespark. Fargekodene som er benyttet på kategorisering av avstand, vinkel og sikt/innsikt, følger trafikklysprinsippet, altså grønt = klart/god, gult = avvent/middels, mens rødt = stans (fare)/dårlig.

tre i tre situasjoner. Med tanke på hvor i straffesparkfeltet selve forseelsen inntraff, var fordelingen fem i rød sone, fem i gul sone og fire i grønn sone (nærmest assistentdommer). Gjennomsnittet i vurderingen av vanskelighetsgraden i de ulike situasjonene var helt likt i de to ekspertpanelene, og kun én situasjon ble vurdert å være opp imot vanskelig, noe som indikerer at disse situasjonene oppfattes som lite kompliserte med tanke på hva som burde være en korrekt dommeravgjørelse. De 13 andre situasjonene ble kategorisert som middels eller lette å vurdere. Fordelingen av type forseelse i straffesparksituasjonen var 11 fellinger, tre dytt og én hands.

I 11 av de 14 videoanalyserte straffesparksituasjonene lot dommeren være å dømme straffespark, mens han dømte straffespark i tre av tilfellene. I de tre situasjonene der dommeren feilaktig tildelte straffespark, var det lag med høy status - basert på resultat/plassering i Tippeligaen de to 
siste sesongene, tilskuerantall på hjemmebane, størrelse på budsjett (se Erikstad, 2013) - som spilte på hjemmebane og angrep mot lag med lav status. Når vi ser nærmere på de situasjonene der den faktiske dommeren lot være å tildele et lag straffespark, inntreffer dette i syv av elleve tilfeller der lag med lav status angrep mot lag med høy status.

I denne studien er enighetsgraden mellom spillerpanelet og dommerpanelet på $78,9 \%$.

\section{Diskusjon}

Målet med denne studien var å undersøke hva som kjennetegner straffesparksituasjoner i toppfotball der spillere og dommere har vurdert dommeravgjørelsen til å være feil. Vi stod igjen med 14 situasjoner som ble videoanalysert (Pearce et al., 2010) og organisert i samsvar med en tematisk analyse (Braun \& Clarke, 2006; Braun et al., 2016) med bakgrunn i dommertekniske faktorer som avstand, vinkel og innsikt til straffesparksituasjonene.

\section{Dommerens avstand, vinkel og innsikt i straffesparksituasjonen}

Da dommerens avstand til straffesparksituasjonene ble analysert, viste det seg at det var kun i to tilfeller at dommer hadde kort avstand til selve hendelsen, operasjonalisert i denne studien til å være mellom o og 10 meter. I åtte tilfeller hadde dommeren middels avstand (10-20 meter), mens det i fire av tilfellene var stor avstand (20 meter eller mer). For toppdommere er det viktig å ha en kort og hensiktsmessig avstand (Mallo et al., 2012) til spillsituasjonene ute på banen, og det er et kriterium at den gjennomsnittlig bør være under 20 meter (NFF, 2017; FA 2017). Når betydningen av og konsekvensene av riktig eller gal avgjørelse i straffefeltet kan være betydelige (Bar-Eli et al., 2007; Baldwin, 2008), er dommerens avstand i 12 av 14 situasjoner enten middels eller stor. Dette kan være lite hensiktsmessig og utgjøre et grunnlag for eventuell feildømming. Når 11 av disse 14 situasjonene oppstod etter etablert spill, der dommeren lett skal kunne holde følge med spillet fordi ballen ikke forflyttes over store avstander på kort tid, kunne avstanden sannsynligvis ha vært kortere. 
Analysen av vinkelen til spillet viste at dommeren i tre tilfeller hadde god og hensiktsmessig vinkel til straffesituasjonen, mens vinkelen var middels eller dårlig i henholdsvis fem og seks tilfeller. Det virker dermed rimelig å anta at dårlig vinkel til en situasjon kan bidra til en gal avgjørelse. Like fullt er mangel på god vinkel overraskende med tanke på at dommeren har en helt klar arbeidsoppgave (NFF, 2017), nemlig å bevege seg etter diagonalen (tenkt linje på skrå av fotballbanen) slik at han eller hun mest mulig kommer vinkelrett på spillet. Med bakgrunn i funn fra tidligere studier (se Mallo et al., 2012; Voight, 2009) er det en utfordring for en dommer å kunne oppnå dette i toppfotballen. Årsakene er at spillet går så hurtig, og at spillerne normalt sett er raskere enn dommeren. I de fleste tilfeller er nok dette tilfelle (Helsen \& Bultynck, 2004), men for å bli rangert dommer i toppfotballen må du i dag bestå fysiske løpstester (UEFA, 2017; NFF, 2017) som er i tråd med utviklingen i moderne fotball, og som gjør at en toppdommer i utgangspunktet skal være i stand til å bevege seg hurtig nok til å få en hensiktsmessig vinkel til spillsituasjoner.

Resultatene fra analysen om innsikt eller dommerens synslinje («line of vision»; UEFA, 2017) viste at i kun tre tilfeller var denne god, mens den var middels i tre tilfeller og dårlig i hele åtte tilfeller. Analysen i denne studien baserer seg på antall spillere som er i synslinjen til dommeren inn mot straffesituasjonen, og som dermed potensielt kan skjerme for viktig informasjon (Mallo et al., 2012; Voight, 2009). Enhver dommer, og spesielt en toppdommer, bør hele tiden ha som overordnet mål å skaffe seg god innsikt - altså unngå å få én eller flere spillere i synslinjen - til en spillsituasjon, og kanskje spesielt i straffesparkfeltet, uavhengig vinkel til situasjonen eller eventuelt til hvor han eller hun befinner seg på diagonalen, for å kunne ta en mest mulig korrekt avgjørelse (Mallo et al., 2012; Voight, 2009).

Karakteristisk for de 14 straffesparksituasjonene som er studert, er at 11 av dem inntreffer etter etablert spill. Med tanke på de fysiske og mentale kravene som stilles til toppdommere (Giske, Haugen, \& Johansen, 2016), er det i utgangspunktet naturlig å hevde at dommeren i etablert spill 1 bør være på riktig sted til riktig tid fordi spillet foregår uten at ballen forflyttes over store avstander på kort tid. Bare to av disse straffesparksituasjonene inntraff etter en overgang eller kontring, der spillet vanligvis går svært raskt fremover, og det er mer naturlig at dommeren kommer 
på etterskudd. Kun én situasjon oppstod etter en såkalt fast situasjon (frispark, hjørnespark eller innkast). I slike tilfeller har dommeren klare retningslinjer for hvor han eller hun bør være plassert med tanke på best mulig avstand, vinkel og innsikt til spillet (NFF, 2017). Det at det kun var én fast situasjon der det var uoverensstemmelse mellom avgjørelsen og paneldeltakernes vurdering, kan tyde på at dommere posisjonerer seg på en måte som gjør at de får god innsikt i disse situasjonene.

Andre kjennetegn ved disse 14 straffesparksituasjonene er at det i 11 av disse kun er to spillere involvert i selve forseelsen, mens det $\mathrm{i}$ tre tilfeller er tre spillere involvert. Dette lave antall spillere burde medføre at dommeren lettere skulle kunne avgjøre om det er begått en straffbar forseelse eller ei. Når det gjaldt type forseelse, viste resultatene at felling av motstander inntraff i 11 av 14 situasjoner, mens dytting inntraff i tre tilfeller og hands i kun ett tilfelle. Dette er alle klassiske forseelser som må være til stede når man skal tildele et lag direkte frispark (jf. regel 12 i spillereglene til NFF), og er kriterier en toppdommer må redegjøre for på teoretiske tester flere ganger i løpet av en sesong (NFF, 2017). Dette - sammen med praktisk trening (å dømme fotballkamper) - skal gjøre ham i stand til å fatte en riktig beslutning, det vil si tildele et lag straffespark når en slik forseelse skjer inne i straffesparkfeltet (jf. regel 14 i spillereglene til NFF).

Vanskelighetsgraden i de ulike straffesparksituasjonene ble i 13 tilfeller vurdert av ekspertpanelene til å være lett eller middels, og kun én situasjon ble vurdert til å være vanskelig, noe som indikerer at disse situasjonene oppfattes som lite kompliserte med tanke på hva som burde være en korrekt dommeravgjørelse. Dette kan indikere at kampdommeren ikke vurderer disse 13 situasjonene feil (tildelt straffespark eller ikke) fordi situasjonene er vanskelige, men fordi dommeren er feilplassert og ikke har tilstrekkelig innsikt til situasjonen (se Mallo et al., 2012; Voight, 2009).

\section{Er dommeren usikker og i tvil i straffesparksituasjonen?}

Med utgangspunkt i at dommeren i de analyserte straffesparksparksituasjonene har hatt stor avstand, dårlig vinkel og/eller dårlig innsikt og dermed også kan ha vært feilplassert i et flertall av situasjonene, er det 
kanskje forståelig at de etter ekspertpanelenes samstemmige vurdering har landet på en gal avgjørelse. I 11 av de 14 videoanalyserte situasjonene lot dommeren være å dømme straffespark. Dette kan tolkes dit hen at dommeren har vært i tvil i disse tilfellene og derfor latt være å dømme et straffespark. Når en dommer i fotball er sterkt i tvil om en avgjørelse, er det en uskreven regel at avgjørelsen skal gå i favør av det forsvarende laget (NFF, 2017). En annen mulig forklaring på denne feildømmingen kan være at dommeren - som følge av en feilposisjonering - er blitt usikker og i tvil og dermed har tatt den avgjørelsen som skaper minst mulig kontroverser for ham selv, en slags «better safe than sorry»-avgjørelse. Haselton og Buss (2000) har lansert teorien om feilhåndtering, der avgjørelser som er tatt ved usikkerhet, og der kostnadene av positive og negative feil har vært asymmetriske over tid, skal få en reaksjon som gir minst mulig skade (Haselton \& Nettle, 2006). En gjennomgang av stilling og tidspunkt i kampene viste ingen klare tendenser til at disse momentene var av betydning.

I situasjonene der kampdommeren dømte straffespark og ingen av deltakerne i de to ekspertpanelene ville ha gjort det, var det var lag med høy status, basert på resultat/plassering i Tippeligaen de to siste sesongene, tilskuerantall på hjemmebane, størrelse på budsjett (se Erikstad, 2013) som spilte på hjemmebane og angrep mot lag med lav status. Det er da nærliggende å hevde at dommeren i disse tilfellene kan ha vært utsatt for sosialt press, noe som er blitt dokumentert i tidligere studier (Erikstad, 2013; Latané, 1981; Nevill, Balmer, \& Williams, 2002; Sutter og Kocher, 2004; Wolfson et al., 2005). Når det gjaldt situasjonene der kampdommeren lot være å tildele et lag straffespark, inntraff dette i syv av 11 tilfeller der lag med lav status angrep mot lag med høy status. Dette indikerer at dommeren kan ha vært påvirket av eksterne kilder.

Det er imidlertid viktig å understreke at dommeren er menneskelig og tar raske beslutninger basert på en subjektiv vurdering av ulike spillsituasjoner (Poolton et al., 2011). Og selv om han eller hun har mulighet til å kunne bevege seg fritt på banen for å skaffe seg best mulig avstand, vinkel og innsyn for å kunne ta en mest mulig korrekt avgjørelse, har ikke dommeren alltid optimal innsikt i en situasjon og må ta en avgjørelse basert på rutine og intuisjon (Plessner et al., 2009). I tillegg har forskning 
(Johansen \& Haugen, 2013) vist at norske toppdommere (Tippeligaen) scorer høyere på før-konkurranseangst enn det dommere på nest høyeste nivå (OBOS-ligaen) gjør. Dette kan forklares med at det ytre presset $\mathrm{i}$ form av flere tilskuere, større medietrykk og oppmerksomhet innen fotballen er betydelig høyere på det øverste nivået enn på nivå to i Norge. Dohmen (2008) støtter opp om dette og viser til at dommere ikke bare må levere som dommer i en kamp, men også takle alt oppstyret rundt den profesjonelle fotballen. Når det i tillegg er dokumentert at en toppdommer må fatte tre til fire beslutninger per minutt jevnt fordelt over en fotballkamp (Helsen \& Bultynck, 2004), er det kanskje urimelig å anta at hver gang dommeren gjør en feil, skal denne avgjørelsen skyldes påvirkning av sosialt press.

Resultatene fra denne studien har avdekket at dommerne har hatt lang avstand til situasjonen, for dårlig vinkel til den og for dårlig innsikt til den når de har dømt eller latt være å dømme straffespark. Det er grunn til å anta at dommerne i disse situasjonene har vært usikre og i tvil om hvilken avgjørelse de skulle ta. De som har en høy tendens til å dvele ved hva de skal gjøre, tar oftere en feil avgjørelse eller dømmer i favør av hjemmelaget (Poolton et al., 2011). Resultatene fra denne studien indikerer at feildømming forekommer oftere når dommerne er feilplassert og har mangelfull informasjon om hendelsesforløpet. Videre ser vi en asymmetri i fordelingen av utfallet av feildømming. Det skjer ved at dommeren i de fleste tilfeller unngår å dømme straffe (11 av 14), og at det er lag med høy status som favoriseres ved feildømming (10 av 14 situasjoner). Sett i lys av EMT, kan det tenkes at det å ikke dømme straffe eller det å ikke dømme mot lag av høy status vil være den avgjørelsen som dommere opplever vil gjøre minst skade (Haselton \& Nettle, 2006).

\section{Styrker og svakheter}

En av styrkene ved denne studien er at de 14 straffesparksituasjonene som er analysert og beskrevet, er plukket ut på bakgrunn av vurderingene til to ekspertpanel, der alle deltakerne mener at kampdommeren har tatt en gal avgjørelse. Derfor er det grunnlag for å hevde at disse situasjonene representerer hendelser der dommeren mest sannsynlig har dømt 
feil. Selv om ekspertpanelet hadde mulighet til å identifisere hvilke lag som var involvert, ble de fleste og potensielt sterkeste kildene til påvirkning fjernet (lyden var av, stillingen i kamp ble sensurert, og noen direkte relasjon med spillerne eksisterer ikke). Weston (2015) hevder at dette er en av grunnene til at bruk av ekspertpanel er en egnet metode når grad av riktighet ved en dommeravgjørelse skal undersøkes. I denne studien ble også enighetsgraden mellom de to ekspertpanelene undersøkt, og den var på $78,9 \%$. En så høy enighetsgrad er med på å styrke grunnlaget for å plukke ut de straffesparksituasjonene som er undersøkt, og derigjennom styrke validiteten i studien. Videre kan det nevnes at panelenes enighet med kampdommernes avgjørelser var 66,3\% for spillerpanelet og $69,4 \%$ for dommerpanelet. Disse resultatene er i tråd med tidligere studier (Schweizer, Plessner, Kahlert, \& Brand, 2011) som viser at man finner en enighetsgrad på 60-79\% når man sammenligner et ekspertpanels vurderinger mot kampdommerens avgjørelser.

Like fullt kan graden av nøyaktighet (antall meter) basert på videoklipp diskuteres, da avstanden er estimert ut ifra hva videobildene viser av dommerens plassering i forhold til ulike markeringer på fotballbanen. I denne studien er alle situasjonene belyst fra tre ulike vinkler, og ulike målinger og vurderinger er blitt foretatt av to eksperter på fagfeltet uavhengig av hverandre (Pearce et al., 2010). En annen klar svakhet ved studien er uthentingen av kamper, mangel på komplett innsikt i videoklippene og muligheten til å vurdere hva kampdommeren faktisk har sett. Dessuten er eventuell kommunikasjon mellom dommer og assistentdommere ukjent. Det kan ha blitt gitt beskjeder på det interne kommunikasjonsnettet som kan ha hatt innflytelse på de avgjørelsene som er blitt fattet. Kjennskap til innholdet i internkommunikasjonen mellom dommerne vil også ha kunnet gitt verdifull informasjon om dommerens eventuelle usikkerhet og tvil i straffesparksituasjonene. Utvalget av situasjoner er for lite som grunnlag for å kunne generaliserer resultatene, noe som da heller ikke var et mål i seg selv. Men et ønske om å oppnå troverdighet (Morrow, 2005) i beskrivelsen av de ulike kjennetegnene ved disse straffesparksituasjonene er å foretrekke, og dette har vært et mål med undersøkelsen. For å styrke troverdigheten (validiteten) i studien ble den videobaserte analysen utført av en person med dommerfaglig bakgrunn. 
Samsvaret mellom de to uavhengige ekspertene i deres karakteristikker av avstand, vinkel og innsikt i de ulike situasjonene var på 98\%, noe som anses å være svært høyt (Pearce et al., 2010).

\section{Perspektiver}

Å svare på spørsmålet om hvor vanskelig det egentlig kan være å dømme et korrekt straffespark i fotball, er - med bakgrunn i resultatene fra denne studien - kanskje noe mer komplisert enn først antatt. Analysen av de ulike straffesparksituasjonene indikerer at dersom dommeren ikke er riktig plassert med en hensiktsmessig avstand, vinkel og innsikt til hendelsesforløpet, blir det vanskelig å fatte en korrekt avgjørelse. En optimal plassering vil mest sannsynlig gjøre dommere i stand til å skaffe seg både relevant og nok informasjon for å dømme eller la være å dømme et straffespark. Fremtidig forskning bør da eksempelvis undersøke kjennetegn ved straffesparksituasjoner der alle i et ekspertpanel er enige i den avgjørelsen kampdommeren har tatt, og å undersøke dommerens plassering. I tillegg ville det vært interessant å eksponere kampdommerne for disse situasjonene for å undersøke hva de så og tenkte, og hvordan de vurderer situasjonene i ettertid.

Dommerens feilplassering - og dermed mest sannsynlig feildømming - i ulike straffesituasjoner som er blitt avdekket i denne studien, underbygger også betydningen av at dommere må være fysisk og mentalt godt forberedt. Kravene til dagens toppdommere gjør at påkrevd hurtighet og tilstrekkelig fotballforståelse blir mer og mer avgjørende for å kunne utføre en optimal prestasjon på banen. Med stadig større vektlegging av dommernes prestasjoner blir det også spesielt viktig å mestre stress og press i toppdommerrollen. Ulike sosiale påvirkningskilder som spillere, trenere, publikum og media gjør at en toppdommer ikke kan fremstå usikker og i tvil om hendelser som inntreffer. Med andre ord - en dommer må bokstavelig talt være fysisk i den rette sonen ute på fotballbanen og ikke minst være i den riktige mentale sonen.

Å unngå all feildømming vil være en nærmest umulig oppgave. FIFA har besluttet å innføre videodømming i VM-sluttspillet i Russland sommeren 2018 for å minimere sjansene for feildømming (FIFA, 2017). Det 
gjøres ved å ha egne videodommere (Video Assistent Referees; VAR) under kampene. Dette er et nytt tiltak som synes å ha en viss verdi (UEFA, 2017), da funn i denne og tidligere studier (f.eks. Sutter \& Kocher, 2004) indikerer at resultatet av dommerens feilaktige avgjørelser ikke er tilfeldig fordelt mellom lagene. Like fullt er VAR en ordning som kan umyndiggjøre fotballdommerne på sikt og potensielt fjerne det fascinerende elementet av dommerens subjektive tolkning av ulike hendelser ute på banen, og dermed gjøre fotballdømming mindre interessant.

\section{Referanser}

Baldwin, C. (2008). The ref cost us the game: The role of sports commentators and journalists in creating stresses on sports referees. In Power and Place: Refereed Proceedings of the Australian and New Zealand Communication Association Conference. Wellington, July 9-11.

Bar-Eli, M., Azar, O.H., Ritov, I., Keidar-Levin, Y. \& Schein, G. (2007). Action bias among elite soccer goalkeepers: The case of penalty kicks. Journal of Economic Psychology, 28, 606-621.

Braun, V. \& Clarke, V. (2006). Using thematic analysis in psychology. Qualitative Research in Psychology, 3, 77-101.

Braun, V., Clarke, V. \& Weate, P. (2016). Using thematic analysis in sport and exercise research (s. 191-205). London: Routledge.

Boyko, R.H., Boyko, A.R. \& Boyko, M.G. (2007). Referee bias contributes to home advantage in English premiership football. Journal of Sports Sciences, 25, 1185-1194.

Di Corrado, D., Pellarin, E. \& Agostini, T.A. (2011). The phenomenon of social influence on the football pitch: Social pressure from the crowd on referees' decisions. Review of Psychology, 18, 33-36.

Dohmen, T.J. (2008). The influence of social forces: Evidence from the behaviour of football referees. Economic inquiry, 46, 411-424.

Erikstad, M.K. (2013). Awarding penalties in soccer. Are referees influenced by the strength of a team when making important decisions? Mastergradsavhandling, Universitetet i Agder, Kristiansand.

FA (Det engelske fotballforbundet) (2017, 08.11) Laws of the Game \& FA Rules. Hentet fra: http://www.thefa.com/football-rules-governance/lawsandrules.

FIFA (2017, 07.04). Referees' road to Russia continues. FIFA. Hentet fra: http:// www.fifa.com/development $/$ news $/ \mathrm{y}=2017 / \mathrm{m}=4 /$ news=referees-road-to-russiacontinues-2878939.html. 
Giske, R., Haugen, T. \& Johansen, B.T. (2016). Training, mental preparation and unmediated practice among soccer referees: An analysis of elite and sub-elite referees' reported practice. International Journal of Applied Sports Sciences, 28, 31-41.

Goumas, C. (2014). Home advantage and referee bias in European football. European Journal of Sport Science, 14, 243-249.

Haselton, M.G. \& Buss, D. (2000). Error management theory: A new perspective on biases in cross-sex mind reading. Journal of Personality and Social Psychology, 78 , 81-91.

Haselton, M.G. \& Nettle, D. (2006). The paranoid optimist: An integrative evolutionary model of cognitive biases. Personality and Social Psychology Review, $10,47-66$.

Helsen, W. \& Bultynck, J.-B. (2004). Physical and perceptual-cognitive demands of top-class refereeing in association football. Journal of Sports Sciences, 22, 179-189.

Jamieson, J.P. (2010). The home field advantage in athletics: A meta-analysis. Journal of Applied Social Psychology, 40, 1819-1848.

Johansen, B.T. \& Haugen, T. (2013). Anxiety level and decision-making among Norwegian top-class soccer referees. International Journal of Sport and Exercise Psychology, 11, 215-226.

Johnston, R. (2008). On referee bias, crowd size, and home advantage in the English soccer premiership. Journal of Sports Sciences, 26, 563-568.

Latané, B. (1981). The psychology of social impact. American Psychologist, 36, 343-356.

Mallo, J., Gonzalez Frutos, P., Juarez, D. \& Navarro, E. (2012). Effect of positioning on the accuracy of decision-making of association football top-class referees and assistant referees during competitive matches. Journal of Sports Sciences, 30 , 1437-1445.

Mascarenhas, D.R.D., Button, C., O’Hare, D. \& Dicks, M. (2009). Physical performance and decision-making in association football referees: A naturalistic study. The Open Sport Sciences Journal, 2, 1-9.

Mascarenhas, D.R.D., O’Hare, D. \& Plessner, H. (2006). The psychological and performance demands of association football refereeing. International Journal of Sport Psychology, 37, 99-120.

Morrow, S.L. (2005). Quality and trustworthiness in qualitative research in counseling psychology. Journal of Counseling Psychology, 52, 250-260.

Mucchi Faina, A. (1996). L'influenza sociale [Social influence]. Bologna: Il Mulino.

Nevill, A., Balmer, N. \& Williams, A. (2002). The influence of crowd noise and experience upon refereeing decisions in football. Psychology of Sport and Exercise, 3, 261-272.

Norges Fotballforbund (2016). Spillereglene 2016/17. Oslo: Norges Fotballforbund.

Norges Fotballforbund (2017). Retningslinjer for 2017. Oslo: Norges Fotballforbund. 
Pearce, C., Arnold, M., Phillips, C. \& Dwan, K. (2010). Methodological considerations of digital video observation: beyond conversation analysis. International Journal of Multiple Research Approaches, 4, 90-99.

Plessner, H. \& Betsch, T. (2001). Sequential effects in important referee decisions: The case of penalties in soccer. Journal of Sport and Exercise Psychology, 23, 254-259.

Plessner, H., Schweizer, G., Brand, R. \& O’Hare, D. (2009). A multiple-cue learning approach as the basis for understanding and improving soccer referees' decision making. Progress in Brain Research, 171, 151-158.

Poolton, J., Siu, C.M. \& Masters, R. (2011). The home team advantage gives football referees something to ruminate about. International Journal of Sports Science \& Coaching, 6, 545-552.

Samuel, R.D. (2015). A Psychological Preparation Framework for Elite Soccer Referees: A Practitioner's Perspective. Journal of Sport Psychology in Action, 6, $170-187$.

Schweizer, G., Plessner, H., Kahlert, D. \& Brand, R. (2011). A video-based training method for improving soccer referees' intuitive decision-making skills. Journal of Applied Sport Psychology, 23, 429-442.

Slack, L.A., Maynard, I.W., Butt, J. \& Olusoga, P. (2013). Factors underpinning football officiating excellence: perceptions of English Premier League referees. Journal of Applied Sport Psychology, 25, 298-315.

Sutter, M. \& Kocher, M.G. (2004). Favouritism of agents - The case of referees' home bias. Journal of Economic Psychology, 25, 461-469.

Thomas, J.R., Silverman, S. \& Nelson, J. (2015). Research methods in physical activity, 7 E. Human kinetics: Champaign, IL.

UEFA (2017, 06.11). Refereeing. Hentet fra: http://www.uefa.com/insideuefa/ protecting-the-game/refereeing/index.html.

Voight, M. (2009). Sources of stress and coping strategies of US soccer officials. Stress and Health, 25, 91-101.

Weinberg, R.S. \& Gould, D. (2007). Foundations of sport and exercise psychology, ( $\left.4^{\text {th }} e d\right)$. Human Kinetics: Champaign, IL.

Weston, M. (2015). Match performances of soccer referees: the role of sports science.

Movement \& Sport Sciences, 1, 113-117.

Wolfson, S. \& Neave, N. (2007). Coping under pressure: Cognitive strategies for maintaining confidence among soccer referees. Journal of Sport Behaviour, 3o, 232-247.

Wolfson, S., Wakelin, D. \& Lewis, M. (2005). Football supporters' perceptions of their role in the home advantage. Journal of Sports Sciences, 23, 365-374. 


\title{
KAPITTEL 11
}

\section{Prinsipper ved test-retest-reliabilitet}

\section{Test av protokoll for maksimal innsats på sykkelrulle med ett minutts varighet}

\author{
Tommy Haugen ${ }^{*}$, Kjetil Marius Ulland Salvesen \& Rune Høigaard \\ Universitetet i Agder, Fakultet for helse- og idrettsvitenskap
}

\begin{abstract}
Sammendrag: Formålet med studien var todelt: 1) Gjennomgå sentrale prinsipper for testretest-reliabilitet, og 2) reliabilitetsteste en protokoll for maksimal innsats på sykkelrulle med ett minutts varighet hos relativt godt trente unge voksne. Forsøkspersonene $(\mathrm{N}=12)$ gjennomførte tre forsøk på sykkelrulle hvor gjennomsnittwatt ble registrert. Resultatene viste ingen signifikant forskjell mellom forsøkene, høy ICC (.996), lav CV og lav TE og SEM. Resultatene indikerte at sykkeltesten har evne til å produsere nøyaktige og stabile målinger. De indikerte også at det ikke ser ut til å forkomme større systematiske feilmålinger som påvirker resultatene i betydelig grad.
\end{abstract}

Nøkkelord: reliabilitetstest, sykkelergometer, innsats, prestasjon

\begin{abstract}
The study aim was twofold: 1) Review basic principles of test-retest reliability, and 2) investigate the reliability of a test procedure of a one-minute time trial on an ergometer bicycle in relatively well-trained young adults. The subjects $(\mathrm{N}=12)$ completed three "all-out" intervals on the bicycle ergometers where average watt produced was recorded. The results of the experiments showed no significant mean differences across tests, high ICC (.996), low $\mathrm{CV}$, TE, and SEM. The findings suggested that the ergometer test had the ability to produce accurate and stable measurements. It also indicated that measurement biases that affected the results did not seem to occur.
\end{abstract}

Keywords: reliability test, bicycle ergometer, effort, performance

\footnotetext{
"Korresponderende forfatter: Tommy Haugen, Fakultet for helse- og idrettsvitenskap, Universitetet i Agder, Postboks 422, 4604 Kristiansand, tlf: +47 3814 23 27, e-post: tommy.haugen@uia.no

Sitering av denne artikkelen: Haugen, T., Salvesen, K.M.U. \& Høigaard, R. (2018). Prinsipper ved testretest-reliabilitet: Test av protokoll for maksimal innsats på sykkelrulle med ett minutts varighet. I T. Haugen \& R. Høigaard (red). Trender i idrettspsykologisk forskning i Skandinavia (Kap. 11, s. 225-238). Oslo: Cappelen Damm Akademisk. DOI: https://doi.org/10.23865/noasp.39.ch11 Lisens CC-BY 4.0
} 


\section{Introduksjon}

Ifølge Murphy og Murphy (2012) legges det betydelig vekt på prestasjon og prestasjonsutvikling innenfor idrettspsykologisk forskning. Ønsket om å avdekke sosiale/psykologiske faktorer som kan påvirke idrettslige prestasjoner (kausalitet), får konsekvenser for valg av studiedesign. Dersom målet for forskningen er å etablere og demonstrere kausale effekter (årsak-virkning) mellom to eller flere variabler, er eksperimentelle studier å foretrekke (Gravetter \& Forzano, 2016).

Idrettspsykologiske eksperimenter medfører behov for kontroll, og av den grunn foregår de ofte under strengt kontrollerte betingelser, som for eksempel i en laboratorium-kontekst. Haugen, Reinboth, Hetlelid, Peters \& Høigaard (2016) og Nilsen, Haugen, Reinboth, Peters \& Høigaard (2014) har for eksempel benyttet seg av repeterte målinger av prestasjon (innsats) på sykkelrulle i et fysiologisk testlaboratorium, hvor en rekke potensielt konfunderende variabler kan kontrolleres (f.eks. vær, temperatur og belastning). Likevel mangler de nevnte studiene en eksplisitt redegjørelse for reproduserbarheten for den benyttede protokollen. I et forskningsdesign som tar i bruk repeterte målinger, vil det alltid være en mulighet for at resultatene blir påvirket av tidligere forsøk (Hassmén \& Hassmén, 2008). Grunner til dette kan være at gjennomføring av tester skaper en læringseffekt, eller at de bidrar til fysisk eller mental utmattelse. Det er derfor avgjørende at målemetodene har høy stabilitet, i tillegg til å kunne registrere naturlige variasjoner (sensitivitet) over tid (Portney \& Watkins, 200o) eller endringer i betingelser. Det vil være avgjørende for studiens evne til å etablere kausale slutninger at eventuelle endringer i målte variabler kan relateres direkte til studiens manipulasjon. Innenfor metodisk litteratur kalles gjerne denne stabiliteten i målinger for reliabilitet. Et måleinstruments reliabilitet kan forklares som stabiliteten og konsistensen til målingene under like betingelser (Field, 2016).

Formålet med denne artikkelen er todelt: Å presentere en gjennomgang av sentrale prinsipper ved test-retest-reliabilitet, samt å reliabilitetsteste en protokoll for repetert maksimal innsats på sykkelrulle med ett minutts varighet, tidligere brukt i Haugen et al. (2016) og Nilsen et al. (2014). 


\section{Testing av reliabilitet}

Reliabilitet refererer til nøyaktigheten og konsistensen til de dataene som samles inn ved en undersøkelse (Polit \& Beck, 2010). Samme måling utført på samme person flere ganger og under samme betingelser skal i utgangspunktet gi samme verdi. Imidlertid er det uvanlig (om ikke umulig) å finne instrumenter som er feilfrie. Alle testmetoder er feilbarlige, og personer responderer med en eller annen grad av inkonsekvens (Field, 2016). Reliabilitet som begrep benyttes gjerne for å reflektere graden av feil (error) som enhver måling innehar (Streiner, Norman, \& Cairney, 2014).

For å oppnå høy reliabilitet er en avhengig av at målingene er nøyaktige, og at målefeilene blir eliminert så langt det er mulig. Klassisk reliabilitetsteori tar utgangspunkt i at alle målinger, eller observert score, består av en sann score og en feilkomponent (error), der den sanne scorens verdi er uavhengig av målemetoden (Thomas, Nelson, \& Silverman, 2005). Differansen mellom den sanne og den observerte scoren blir ofte betraktet som summen av tilfeldige og systematiske feilmålinger. Ved å identifisere graden av målefeil bedres forutsetningen for å forutse variasjon som forekommer ved målinger (Portney \& Watkins, 200o). Tilfeldige feilmålinger (random error) påvirker resultatet av en test på en uforutsigbar måte. Disse målefeilene kan føre til tilfeldige resultater, og de kan påvirke ulikt fra måling til måling, og fra individ til individ (Weir, 2005). Årsaken til tilfeldige feilmålinger kan være biologiske og/eller mekaniske, eller de kan skyldes en ikke-standardisert testprotokoll. Ofte er komponentene av tilfeldige feil større enn komponentene av systematisk målefeil (Atkinson \& Nevill, 1998).

Systematiske feil (bias/systematic error) har på sin side en tendens til å påvirke resultatet (kollektivt) i en bestemt retning. Det kan for eksempel forekomme ved tillæring av en bestemt oppgave som måles, ved utilstrekkelig restitusjon ved utmattende fysiske tester eller ved feil kalibrering av måleinstrument (Portney \&Watkins, 200o). For å sikre at målingene ikke blir påvirket av tretthet, hukommelses- eller læringseffekt, er det avgjørende at tidsrommet mellom målingene blir tilpasset studien og metoden som benyttes (Robertson, Burnett, \& Cochrane, 2014). Dersom intervallet mellom målingene blir for langt, kan det skje naturlige endringer $\mathrm{i}$ den målevariabelen man har til hensikt å påvirke (Hassmén \& Hassmén, 2008; Robertson et al., 2014). 
I denne sammenhengen er test-retest-reliabilitet av spesiell interesse (Rousson, Gasser, \& Seifert, 2002). Dette kan gi et mål på instrumentets tidsmessige stabilitet (Hassmén \& Hassmén, 2008). Ved en slik reliabilitetstesting blir ofte en gruppe individer utsatt for samme test/måling ved to eller flere anledninger, hvor en så sammenligner resultatene (Portney \& Watkins, 2000). For å undersøke om det forekommer indikasjoner på systematiske feil (f.eks. læringseffekt, tretthet eller motivasjonssvikt) i en gruppe som måles ved flere anledninger, brukes gjerne paired sample t-test (to tester) eller repeated measures ANOVA (tre eller flere tester; Polit \& Beck, 2010). Undersøkelse av eventuelle forskjeller mellom gjennomsnitt fra test til test gir svar på hvorvidt gruppens testresultater som helhet reduseres eller økes (Polit \& Beck, 2010). En reliabel test uten betydelig systematisk feilmåling vil produsere lik sentraltendens for gruppen på tvers av tester.

Begrepet reliabilitet omfatter gjerne både relativ og absolutt reliabilitet (Baumgartner, 2003; Weir, 2005). Relativ reliabilitet er knyttet til graden av stabilitet i rank-posisjon i et utvalg, på tvers av gjentatte tester. Absolutt reliabilitet er på sin side knyttet til graden av individuell variasjon fra måling til måling (Domholdt, 2005).

Relativ reliabilitet kan kvantifiseres ved en korrelasjonskoeffisient (Atkinson \& Nevill, 1998). Pearsons produkt-moment korrelasjonskoeffisient er en av de mest brukte estimeringene (ved to tester) av reproduserbarheten av målinger (Polit \& Beck, 2010). En høy koeffisient viser at to ulike målinger gir relativt like resultater for de fleste individer. Dette vil indikere at testen gir stabile målinger over en viss tid (Polit \& Beck, 2010). Ved en ustabil test, der målingene er tatt med kort tidsintervall (eller uten at noen forventede forandringer skal ha forekommet), vil korrelasjonskoeffisienten være lav. Korrelasjonskoeffisienten kan anses som et uttrykk for presisjonen av målingene, men kan påvirkes av homogenitet i utvalget (Hopkins, 200o). Ved tre eller flere gjentatte målinger på samme variabel benyttes gjerne en multivariat reliabilitetskoeffisient, for eksempel Intraclass correlation (ICC). Hva som kan anses som en akseptabel koeffisient, må vurderes på bakgrunn av hva som måles, måleinstrumentets nøyaktighet og hva resultatene skal benyttes til (Hassmén \& Hassmén, 2008). Det vil si at hva som kan betraktes som tilfredsstillende 
korrelasjon, vil variere. For tekniske måleinstrumenter forventes høyere koeffisient enn det som kreves ved måling av fenomener som i mindre grad lar seg påvirke av forsøkspersonene eller testleder (Hassmén \& Hassmén, 2008). Ved kliniske forsøk er en ICC/r-verdi .90 foreslått som en indikasjon på «høy» relativ reliabilitet (Hassmén \& Hassmén, 2008). Gjennomføring av fysiske prestasjonstester på friske voksne i alderen 18 til 30 år hvor testen innehar veldefinerte prestasjonsscorer, tenderer til å gi reliabilitetsmålinger som ligger rundt øvre del av .70 til nedre del av .9o (Baumgartner, 2003).

Korrelasjon mellom to eller flere målinger sier noe om samvariasjonen mellom dem: Dersom den relative rangeringen i et utvalg er stabil, vil dette gi seg utslag i høy korrelasjon. Men høy korrelasjon kan ikke gi oss informasjon om systematiske feil, og det er anbefalt at relativ reliabilitet suppleres med mål på absolutt reliabilitet (Chinn, 1990; Domholdt, 2005). Lav grad av individuell variasjon vil tilsi høy grad av absolutt reliabilitet. For å måle den absolutte reliabiliteten kan eksempelvis Typical Error (TE; $\mathrm{SD}_{\text {diff }} / \sqrt{2}$ ), Standard Error of Measurement (SEM; SDpooled $\left.\sqrt{ }^{(1-r)}\right)$, variasjonskoeffisienten (CV; SD $\left.{ }_{\text {diff }} / M_{\text {pooled }}{ }^{*} 100\right)$ samt Bland-Altmans $95 \%$ limits of agreement (Bland \& Altman, 1986) benyttes. TE og SEM kvantifiserer «typisk» målefeil i samme enhet som instrumentets måleenhet (Stratford \& Goldsmith, 1997). Lavere verdier indikerer at målingsmetoden innehar høyere absolutt reliabilitet (Burton, Conway, \& Holgate, 200o). Små individuelle endringer muliggjør oppdagelsen av små, men avgjørende endringer i målingsvariabelen (Batterham \& George, 2003). CV oppgis i prosent og er en variasjonskoeffisient som er uavhengig av måleenhet (dimensjonsløs). Høyere reliabilitet vises ved lavere CV (Hopkins, 200o). Heterogenitet i utvalget har mindre påvirkning på TE, SEM og CV enn hva tilfellet er ved Pearsons korrelasjonskoeffisient (Burton et al., 20oo).

Bland-Altmans 95\% limits of agreement er et annet mål på absolutt reliabilitet, og innebærer som regel presentasjon av et såkalt Bland-Altmanplott, som visuelt illustrerer sammenhengen mellom to målinger. $95 \%$ limits of agreement indikerer et intervall for feilmålinger som lar seg evaluere med bakgrunn i praktisk relevans. Bland-Altman-plottet illustrerer gjennomsnittsverdien (x-akse) og differansen mellom to målinger (y-akse). Eventuelle uteliggere (outliers) og feil kan derfor observeres visuelt. 


\section{Reliabilitetstest av protokoll for repetert maksimal innsats på sykkelrulle med ett minutts varighet}

Tidligere studier (Haugen et al., 2016; Nilsen et al., 2014) har i idrettspsykologiske eksperimenter som nevnt benyttet en protokoll for (repeterende) innsats/prestasjon på sykkelrulle under ulike sosiale/psykologiske betingelser, men protokollen er - så langt vi kjenner til - ikke tidligere reliabilitetstestet. Videre i denne studien ønsker vi av den grunn å reliabilitetsteste en protokoll for repetert maksimal innsats på sykkelrulle med ett minutts varighet.

\section{Metode}

Utvalg. Deltakerne i studien er et bekvemmelighetsutvalg bestående av bachelorstudenter i idrettsvitenskap ved Universitetet i Agder. Inklusjonskriteriene var 1) (selvvurdert) god fysisk form og 2) skade- og sykdomsfrihet. Åtte menn og fire kvinner med gjennomsnittlig alder $23.3(s d=1.4)$ år samtykket til deltakelse. Seks av deltakerne var aktive konkurranseidrettsutøvere (fotball eller håndball), de resterende var tidligere aktive idrettsutøvere. Gjennomsnittlig trente de $4.9(s d=0.40)$ økter per uke med en gjennomsnittlig varighet på $1.4(s d=0.5)$ timer per økt. Deltakerne ble i forkant av studien informert om studiens hensikt, risiko og dens frivillige karakter. Studien ble godkjent av Etisk komité ved Universitetet i Agder.

\section{Prosedyrer}

Forsøkspersonene gjennomgikk tre tester på sykkelrulle (ett minutt med maksimal innsats) under identiske betingelser: familiseringstest (Fam), test 1 (T1) og test 2 (T2). Testene ble gjennomført på samme dag med en total gjennomføringstid på omtrent fire timer. Deltakerne ble i forkant av sykkeltestene bedt om å fylle ut et spørreskjema slik at vi kunne innhente bakgrunnsinformasjon. De fikk en innføring i bruk av sykkelen og prosedyren som skulle gjennomføres. Syklene ble innstilt etter deltakernes kroppsbygning og preferanser, og de fikk ca. ti minutter til å bli fortrolige med syklene samt utføre finjustering av sete og gir. Forsøkspersonene måtte også angi det giret (utvekslingen) de ville benytte gjennom alle testene. 
I forkant av testene gjennomgikk forsøkspersonene en selvstyrt oppvarming på ti minutter. Hver test hadde en varighet på ett (1) minutt. Forsøkspersonene ble informert om å holde en selvregulert maksimal innsats i hver test, og at gjennomsnittlig wattproduksjon i hver test ville bli registrert. Ved oppstart var pedalene i horisontal posisjon. Testleder startet testene med en nedtelling fra tre før startsignal ble gitt. Verbal tilbakemelding om gjenværende tid ble gitt hvert 15 . sekund. Restitusjonstiden mellom hver test var 45 minutter, inkludert ny oppvarming.

Alle tester ble gjennomført på CompuTrainer Lab-ruller (RacerMate, 2016) med Nakamura 3.0 sykkelmodeller. Ergometerrullene er datastyrt gjennom programvaren RaceMate One, som automatisk regulerer motstanden ved hjelp av en elektronisk brems. Det er påvist at CompuTrainer Lab-rullene har en konstant belastning over et bredt belastningsspekter med en nøyaktighet på $\pm 2.5 \%$ (Racer Mate, Seattle, WA, USA). Før hver test ble det gjennomført en 15 minutters progressiv oppvarming (av utstyret; gjennomført av testledere) hvor belastningen gradvis ble $ø \mathrm{kt}$ fra 50 til 150 watt. Den progressive oppvarmingen klargjorde sykkelrullene gjennom å varme opp sykkeldekkene og ergometerrullen slik at en oppnådde den påkrevde driftstemperaturen for korrekte målinger. Deretter ble rullemotstanden kalibrert ved en roll-down resistanceprosedyre, hvor hjulmotstanden ble kalibrert til mellom 3.50 og 4.00 pund. Kalibreringsverdien ble lagret for den enkelte sykkel og benyttet av programvaren til RaceMate One for å beregne gjennomsnittswatt gjennom hver test.

\section{Statistiske analyser}

Statistiske analyser er gjennomført i SPSS, versjon 24.0, og GraphPad Prism, versjon 6.07. Preliminære analyser av normalfordeling ble gjennomført på alle testtidspunkter. D’Agostino \& Pearsons omnibus normality test og visuell vurdering av Q-Q-plott, histogram og boxplott ble benyttet. For å undersøke systematiske målefeil mellom familiseringstest, test 1 og test 2 ble det gjennomført repeated measures ANOVA. Parvise test-retest-korrelasjoner av målingene ble undersøkt og vurdert ved bruk av Pearson produkt-moment korrelasjonskoeffisent $(r)$, samt Intraclass 
correlation (ICC) koeffisient (two-way mixed) for alle tre gjennomføringene. En $p$-verdi $<.05$ ble ansett som statistisk signifikant. Absolute agreement for målingene ble undersøkt ved bruk av variasjonskoeffisent (CV\%), Standard Error of Measurement (SEM) og Typical Error (TE). Bland-Altman 95\% limits of agreement og tilhørende plott ble gjennomført for å illustrere test-retest-stabilitet.

\section{Resultater}

D'Agostino \& Pearsons omnibus normality test viste tilfredsstillende normalfordeling på alle tre målepunkter $\left(\mathrm{K}_{2}(p)\right.$ : Fam $=0.74(0.69)$; $\left.\mathrm{T}_{1}=1.74(\mathrm{o} .42) ; \mathrm{T}_{2}=1.88(\mathrm{o} .39)\right)$. Tabell 1 viser rådata for de tolv testpersonene for alle tre tester. Figur 1 presenter gjennomsnittwatt og standardavvik $(s d)$ for de tre testene, samt individuelle mål som illustrasjon på spredning.

Tabell 1. Prestasjon (watt) på ett minutts maksimal innsats på sykkelrulle for hver testperson i alle testforsøk.

\begin{tabular}{|l|l|l|l|l|l|l|}
\hline Person & Fam & Fam vs. T1 & T1 & T1 vs T2 & T2 & Fam vs. T2 \\
\hline $1^{\mathrm{a}, \mathrm{d}}$ & 538 & & 536 & & 533 & \\
\hline $2^{\mathrm{a}, \mathrm{c}}$ & 524 & & 527 & & 524 & \\
\hline $3^{\mathrm{b}, \mathrm{c}}$ & 329 & & 315 & & 324 & \\
\hline $4^{\mathrm{b}, \mathrm{d}}$ & 380 & & 368 & & 384 & \\
\hline $5^{\mathrm{b}, \mathrm{d}}$ & 416 & & 392 & & 398 & \\
\hline $6^{\mathrm{b}, \mathrm{c}}$ & 353 & & 350 & & 334 & \\
\hline $7^{\mathrm{a}, \mathrm{d}}$ & 501 & & 492 & & 517 & \\
\hline $8^{\mathrm{a}, \mathrm{d}}$ & 590 & & 570 & & 570 & \\
\hline $9^{\mathrm{a}, \mathrm{c}}$ & 531 & & 553 & & 556 & \\
\hline $10^{\mathrm{a}, \mathrm{d}}$ & 435 & & 432 & & 442 & \\
\hline $11^{\mathrm{a}, \mathrm{c}}$ & 433 & & 425 & & 423 & \\
\hline $12^{\mathrm{a}, \mathrm{c}}$ & 475 & & 465 & & 471 & \\
\hline Pearson's r & & $0.991^{\star \star}$ & & $0.992^{\star \star}$ & & $0.987^{\star \star}$ \\
\hline TE (watt) & & 8.37 & & 7.40 & & 9.83 \\
\hline CV (\%) & & 2.60 & & 2.30 & & 3.04 \\
\hline SEM (watt) & & 7.73 & & 7.24 & & 9.21 \\
\hline
\end{tabular}

Note. Verdiene oppgitt som gjennomsnittswatt produsert. $\mathrm{N}=12$. ${ }^{\mathrm{a}} \mathrm{mann},{ }^{\mathrm{b}} \mathrm{kvinne},{ }^{\mathrm{c}}$ aktiv idrettsutøver, dikke aktiv idrettsutøver. TE = Typical Error; CV = Coefficient of Variation; SEM $=$ Standard Error of Measurement; ${ }^{\star \star}=$ statistisk signifikant $(p<.01)$. 
Som vist i figur 1 var det ingen signifikant forskjell i wattproduksjon mellom de ulike testforsøkene $(F(d f)=2.17(2), p=.16)$. Konsistensen på målingene over tid var høy: Gjennomsnittlig ICC var .996 for de tre testene (Fam, $\mathrm{T}_{1}$ og $\mathrm{T}_{2}$ ), og Pearson-korrelasjon mellom testene var for alle parvise sammenhenger .99 $(p<.01)$. I tillegg viste SEM, TE og CV til relativt lav grad av variasjon (se tabell 1 ).

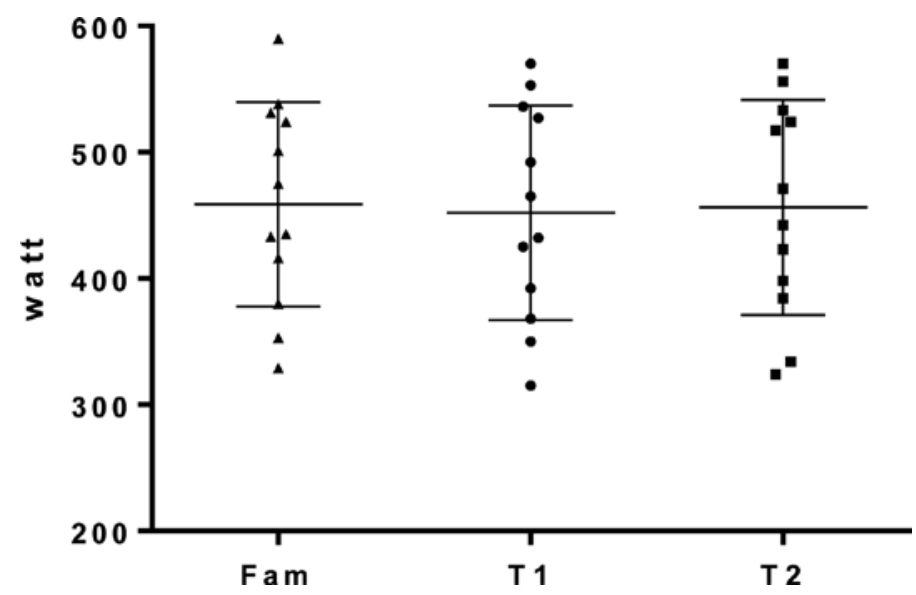

Figur 1. Gjennomsnittswatt og standardavvik for familisering, test 1 og test 2.

Note. Fam = familiseringstest; $\mathrm{T} 1=$ test $1 ; \mathrm{T} 2$ = test 2 . Ingen statistisk signifikant forskjell mellom noen av testene (repeated measures ANOVA: $(F(d f)=2.17(2), p=.16)$.

Figur 2-4 viser Bland-Altman-plott for målingene. Gjennomsnittlig bias for de tre parvise sammenhengene var -3.3.

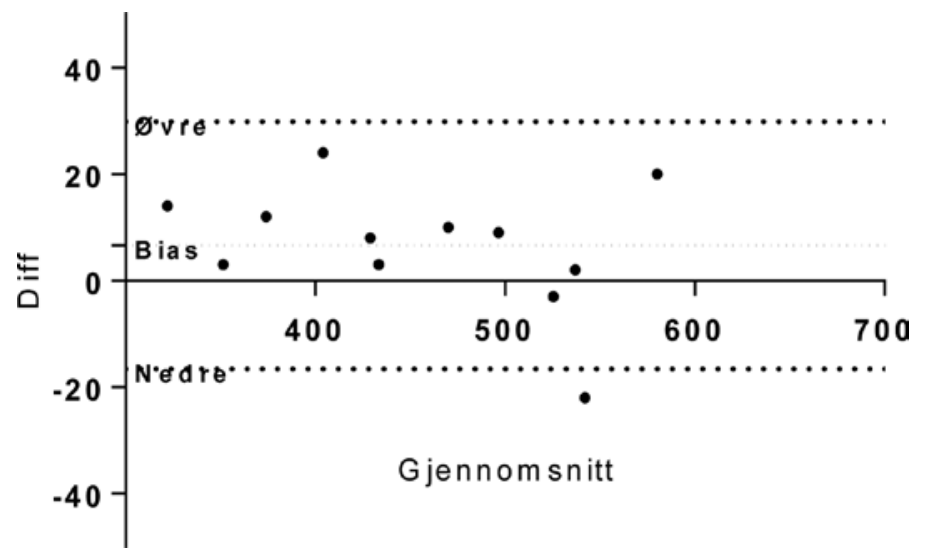

Figur 2. Bland-Altman-plott for familisering vs. T1 test.

Note. Øvre = Upper 95\% limit of agreement; Nedre = Lower 95\% limit of agreement; Bias = Mean difference (6.67). Diff = differanse $($ T1-Fam). 


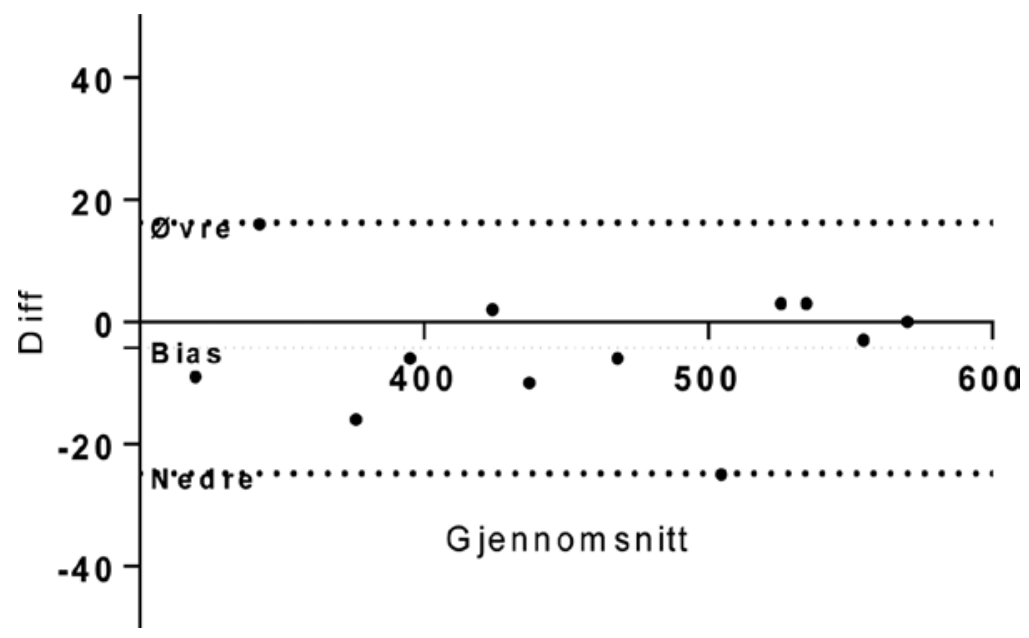

Figur 3. Bland-Altman-plott for $\mathrm{T} 1 \mathrm{vs.} \mathrm{T} 2$.

Note. Øvre = Upper 95\% limit of agreement; Nedre = Lower 95\% limit of agreement; Bias $=$ Mean difference $(-4.25)$. Diff $=$ differanse $($ T2-T1).

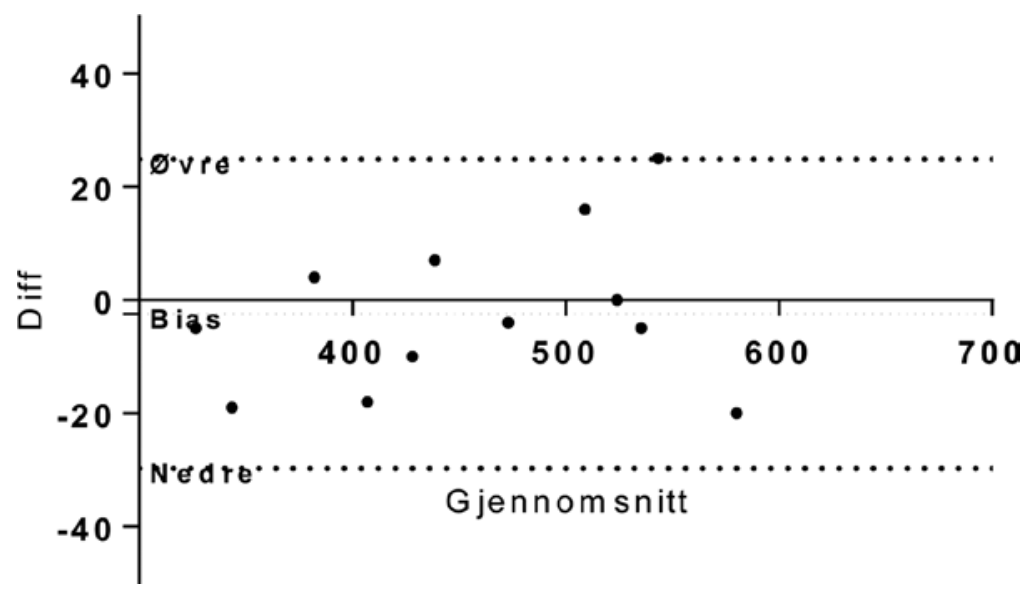

Figur 4. Bland-Altman-plott for familisering vs. T2.

Note. Øvre = Upper 95\% limit of agreement; Nedre = Lower 95\% limit of agreement; Bias $=$ Mean difference $(-2.42)$. Diff $=$ differanse $($ T2-Fam $)$.

\section{Diskusjon}

Formålet med studien var å gjennomgå prinsipper for test-retest-reliabilitet, samt å reliabilitetsteste en protokoll for maksimal innsats på sykkelrulle med ett minutts varighet. Testprotokollen har blitt benyttet for å registrere (repeterende) innsats/prestasjon under ulike sosiale/ 
psykologiske betingelser (Haugen et al., 2016; Nilsen et al., 2014). Laboratorietester på innsats/prestasjon blir ofte brukt i idrettspsykologiske eksperimenter, hvor en empirisk forsøker å etterprøve kausale teoretiske mekanismer (se for eksempel Haugen et al., 2016; Høigaard, et al., 2006; Williams, et al., 1989). Det vil da være avgjørende at eventuell variasjon fra én test til en annen kan relateres til de manipulerte betingelsene, og ikke læringseffekt, tretthet eller tilfeldig målingsstøy. Reliabilitet er et komplekst begrep, og hvorvidt et måleinstrument er reliabelt eller ikke, er i stor grad åpent for fortolking.

Resultatene fra denne studien viser at den testede protokollen ser ut til å ha en tilfredsstillende evne til å produsere nøyaktige og stabile målinger. Det ser ikke ut til å forkomme systematiske feilmålinger som påvirker resultatene i betydelig grad. Funn viser med andre ord ingen tegn til markert læringseffekt (systematisk forbedret prestasjon fra én test til en annen) eller markert tretthet (systematisk reduksjon i prestasjon fra én test til en annen). Resultatene fra denne studien er i samsvar med lignende forsøk (for metastudie, se Hopkins, Schabert, \& Hawley, 2001).

Imidlertid er det noen forhold rundt den aktuelle reliabilitetstestingen som kan være relevant å belyse. For det første var alle forsøkspersonene aktive utøvere eller tidligere aktive personer som anså seg selv å være i relativt god fysisk form. Hopkins et al. (2001) hevder at når en benytter godt trente deltakere, blir det gjerne høyere reliabilitet på powerbaserte tester enn når en benytter ikke-aktive personer. Trente individer har gjerne mer erfaring med høyintensivt arbeid gjennom trening og/eller konkurranse, og har dermed større evne til å opprettholde maksimal innsats. Innsatsperiodens lengde kan også påvirke individuell variasjon. Tester med en varighet på mindre enn 30 sekunder og på over 60 minutter er mindre stabile enn tester innenfor dette tidsspennet (Hopkins et al., 2001). Det forklares med at enkelte bevegelser blir mindre avgjørende for den totale prestasjonen dersom det er et høyt antall gjentakende bevegelser. Samtidig, med økende innsatsperiode vil intensitetsreguleringen og motivasjonen til å presse seg maksimalt kunne påvirkes og negativt påvirke reliabiliteten (Hopkins et al., 2001).

Restitusjonstiden mellom tester kan være avgjørende for resultatene. Ved et kort tidsrom mellom test og retest vil resultatene kunne variere på 
grunn av tretthet, utmattelse eller utilstrekkelig næringsinntak (Hopkins et al., 2001). Derfor er det viktig å tilpasse restitusjonstiden mellom tester slik at forsøkspersonene er restituert og har mulighet til å prestere maksimalt ved repeterende forsøk. Rent fysiologisk kan en anta at 30 minutter eller mer er tilstrekkelig for fullstendig restitusjon etter 6o sekunders maksimal innsats (McArdle, Katch, \& Katch, 2015). Resultatene fra reliabilitetsstudien indikerer relativt små forskjeller mellom testene, og 45 minutters restitusjon/pause mellom testene ser ut til å være tilfredsstillende for gjeldende prosedyre. En såpass lang restitusjonstid vil samtidig muliggjøre eksperimentell manipulasjon (i intervensjonsgruppe) i fremtidige studier, noe som kan være avgjørende for psykologiske eksperimenter (se for eksempel Nilsen et al., 2014).

Denne studien hadde som mål å undersøke relativ og absolutt reliabilitet i en protokoll med gjentatte prestasjonsmål i en kontrollert laboratoriekontekst. Hensikten var å etablere en trygghet om at fremtidige psykologiske eksperimenter kan gjennomføres, hvorpå eventuelle endringer kan tilskrives den aktuelle manipulasjonen. Imidlertid bør det legges til at studien ikke forholder seg til protokollens validitet. Validitet kan beskrives som en metodes evne til å måle det som det er til hensikt å måle (Polit \& Beck, 2010; Portney \& Watkins, 200o). Validiteten i en studie er blant annet avhengig av hvor relevante de empiriske dataene er for problemstillingen. På samme måte som reliabilitet er validitet avhengig av en kritisk evaluering av det metodiske grunnarbeidet (Polit \& Beck, 2010). Høy grad av reliabilitet er en forutsetning for å oppnå høy validitet, men det er ikke en garanti for validiteten (Portney \& Watkins, 200o).

\section{Konklusjon}

Resultatene i denne studien viser at en testprotokoll med selvstyrt maksimal innsats i ett minutt (på CompuTrainer Lab-ruller) produserer målinger med akseptabel nøyaktighet og stabilitet blant individer i relativt god fysisk form. Det kan derfor anses som en tilfredsstillende protokoll for bruk i eksperimentelle idrettspsykologiske studier som har til hensikt å manipulere på betingelser som kan påvirke individuell innsats. Imidlertid bør det presiseres at størrelsen på og homogeniteten (bachelorstudenter 
i idrettsvitenskap) i utvalget medfører at resultatene ikke nødvendigvis kan generaliseres til en mer heterogen populasjon (utrente, eldre, barn), men først og fremst generaliseres til et lignende utvalg.

\section{Referanser}

Anshel, M.H. (1995). Examining social loafing among elite female rowers as a function of task duration and mood. Journal of Sport Behavior, 18, 39-50.

Atkinson, G. \& Nevill, A.M. (1998). Statistical methods for assessing measurement error (reliability) in variable relevant to sports medicine. Sports Medicine, 26, 217-238.

Batterham, A.M. \& George, K.P. (2003). Reliability in evidence-based clinical practice: A primer for allied health professionals. Physical Therapy in Sport, 4, 122-128.

Baumgartner, T.A. (2003). Measurement for Evaluation in Physical Education and Exercise Science ( $7^{\text {th }}$ ed). Boston, MA: McGraw-Hill.

Bland, J.M. \& Altman, D.G. (1986). Statistical methods for assessing agreement between two methods of clinical measurement. The Lancet, 8, 307-310.

Burton, A., Conway, J.H., \& Holgate, S.T. (2000) Reliability: What is it, and how is it measured? Physiotherapy, 86, 94-99.

Chinn, S. (1990). The assessment of methods of measurement. Statistics in Medicine, 9, 351-362.

Domholdt, E. (2005). Rehabilitation research: principles and applications ( $3^{\text {rd }}$ ed.). St. Louis, MI: Elsevier Saunders.

Field, A. (2016). An adventure in statistics: The reality enigma. Thousand Oaks, CA: Sage Publications Inc.

Gravetter, F.J. \& Forzano, L.-A.B. (2016). Research Methods for the Behavioral Sciences $\left(5^{\text {th }}\right.$ ed.). Stamford, CT: Cengage Learning.

Hassmén, N. \& Hassmén, P. (2008). Idrottsvetenskapliga forskningsmetoder. Stockholm: SISU Idrottsböcker.

Haugen, T., Reinboth, M., Hetlelid, K.J., Peters, D.M., \& Høigaard, R. (2016). Mental toughness moderates social loafing in cycle time-trial performance. Research Quarterly for Exercise and Sport, 87, 305-310.

Hopkins, W.G. (2000). Measures of reliability in sports medicine and science. Sports Medicine, 3o(1), 1-15.

Hopkins, W.G., Schabort, E.J., \& Hawley, J.A. (2001). Reliability of power in physical performance tests. Sports Medicine, 31(3), 211-234.

Høigaard, R. (2010). Social loafing in sport: From theory to practice. Saarbrücken, Germany: VDM Verlag Dr. Müller Aktiengesellschaft \& Co. 
Høigaard, R., Tofteland, I., \& Ommundsen, Y. (2006). The effect of team cohesion on social loafing in relay teams. International Journal on Applied Sports Sciences, 18 , $59-73$.

Karau, S.J. \& Williams, K.D. (1993). Social loafing: A meta-analytic review and theoretical intergration. Journal of Personality and Social Psychology, 65, 681-706.

Latané, B. (1986). Responsibility and effort in organizations. I P. Goodman (red.), Groups and organizations (s. 277-303). San Francisco, CA: Jossey-Bass.

McArdle, W.D., Katch, F.I., \& Katch, V.L. (2015). Exercise Physiology: Nutrition, Energy, and Human Performance ( $8^{\text {th }} e d$.). Baltimore, MD: Wolters Kluwer, Lippincott Williams \& Wilkins.

Polit, D.F. \& Beck, C.T. (2010). Essentials of Nursing Research: Appraising Evidence for Nursing Practice. Philadelphia, PA: Wolters Kluwer, Lippincott Williams \& Wilkins.

Portney, L.G. \& Watkins, M.P. (200o). Foundations of Clinical Research: Applications to Practice ( $2^{\text {nd }} e d$.). New Jersey, NJ: Prentice Hall.

RacerMate. (2016). Compu Lab. Available from: http://www.racermateinc.com/ computrainer/ hentet 7. mai 2016.

Robertson, S.J., Burnett, A.F., \& Cochrane, J. (2014). Tests Examining Skill Outcomes in Sport: A Systematic Review of Measurement Properties and Feasibility. Sports Medicine, 44(4), 501-518.

Rousson, V., Gasser, T., \& Seifert, B. (2002). Assessing intrarater, interrater and test-retest reliability of continuous measurements. Statistics in Medicine, 21(22), 3431-3446.

Stratford, P.W. \& Goldsmith, C.H. (1997). Use of the standard error as a reliability index of interest: an applied example using elbow flexor strength data. Physical Therapy, 77(7), 745-750.

Streiner, D.L., Norman, G.R., \& Cairney, J. (2014). Health measurement scales: a practical guide to their development and use $\left(5^{\text {th }} \mathrm{ed}\right)$. St.Ives, UK: Oxford University Press.

Swain, A. (1996). Social loafing and identifiability: The mediating role of achievement goal orientations. Research Quarterly for Exercise and Sport, 67, 337-344.

Thomas, J.R., Nelson, J., \& Silverman, S. (2005). Research Methods in Physical Activity, $\left(5^{\text {th }}\right.$ ed $)$. Champaign, IL: Human Kinetics.

Weir, J.P. (2005). Quantifying test-retest reliability using the intraclass correlation coefficient and the SEM. Journal of Strength \& Conditioning Research, 19(1), 231-240.

Williams, K.D., Nida, S.A., Baca, L.D., \& Latané, B. (1989). Social loafing and swimming: Effects of identifiability on individual and relay performance of intercollegiate swimmers. Basic and Applied Social Psychology, 10, 73-81. 


\title{
Effekt av feedback på kollektiv mestringstro og sosial loffing i et sykkeleksperiment
}

\author{
Tommy Haugen $¥$, Kjetil Marius Ulland Salvesen \& Rune Høigaard \\ Universitetet i Agder, Fakultet for helse- og idrettsvitenskap
}

\begin{abstract}
Sammendrag: Formålet med studien var å undersøke i hvilken grad verbal tilbakemelding (positiv og negativ) påvirket deltakernes kollektive mestringstro, samt i hvilken grad en økning i mestringsforventning ville påvirke tilbøyeligheten til sosial loffing i en idrettslig gruppekontekst hvor individuell innsats ikke blir opplevd som identifiserbar. 66 idrettsstudenter gjennomførte et intervall med ett minutts maksimal innsats på sykkelergometer under individuelle betingelser. Randomisert i lag der halvparten mottok positiv tilbakemelding og resten negativ tilbakemelding, gjennomførte de tre fors $ø \mathrm{k}$ under kollektive betingelser. Deltakernes tro på lagets seiersmulighet ble rapportert i forkant av andre og tredje forsøk. Resultatene viste at tilbakemelding påvirket deltakernes kollektive mestringsforventning, men det ble ikke registrert noen signifikant forskjell i prestasjon mellom gruppene.
\end{abstract}

Nøkkelord: innsats, prestasjon, feedback, kollektiv mestringstro, sosial loffing, mediasjon

\begin{abstract}
The aim of the study was to examine the extent in which verbal feedback (positive and negative) affected the collective efficacy, and to what extent an increase in collective efficacy would affect the propensity to social loafing in a sport group context where individual effort is not perceived as identifiable. 66 sports students conducted an interval of one-minute maximum effort on the bike ergometer under individual conditions. Participants were then randomized into teams in which half of them received positive feedback, while the others received negative feedback, before they then carried out three trials under collective conditions. The participants' belief in the team's victory chance was reported ahead of the second and third attempt. The results show that feedback affected the collective efficacy, but there was a non-significant difference in performance between the groups.
\end{abstract}

Keywords: effort, performance, feedback, collective efficacy, social loafing, mediation

\footnotetext{
${ }^{\text {Y}}$ Korresponderende forfatter: Tommy Haugen, Fakultet for helse- og idrettsvitenskap, Universitetet i Agder, Postboks 422, 4604 Kristiansand, tlf: +47 381423 27, e-post: tommy.haugen@uia.no

Sitering av denne artikkelen: Haugen, T., Salvesen, K.M.U. \& Høigaard, R. (2018). Effekt av feedback på kollektiv mestringstro og sosial loffing i et sykkeleksperiment. I T. Haugen \& R. Høigaard (red). Trender i idrettspsykologisk forskning i Skandinavia (Kap. 12, s. 239-255). Oslo: Cappelen Damm Akademisk. DOI: https://doi.org/10.23865/noasp.39.ch12

Lisens CC-BY 4.0
} 


\section{Introduksjon}

Studier har vist at teamarbeid kan bidra til økt innsats og bedre prestasjon, det kan gi mindre fravær og mer trivsel (Cohen, Ledford, \& Spreitzer, 1996; Prapavessis \& Carron, 1997; Wellins, Byham, \& Dixon, 1994). Samtidig viser forskning også at det å jobbe i en gruppe ikke alltid er like motiverende og bidrar til god innsats. Allerede for over hundre år siden undersøkte Maximilien Ringelmann (1913) forholdet mellom individuell prestasjon og gruppeprestasjon, og resultatene fra hans studier viste en reduksjon i innsats/prestasjon ved økt gruppestørrelse. En nedgang i motivasjon og innsats ved gruppearbeid blir ofte omtalt som sosial loffing, og defineres av Karau og Williams (1993, s. 681) som «the reduction in motivation and effort when individuals work collectively compared with when they work individually or coactively». Forskning på sosial loffing viser at det er et robust fenomen som forekommer blant både menn og kvinner, i ulike kontekster og i tilknytning til ulike arbeidsoppgaver (Karau \& Williams, 1993). Innenfor idrett har forskning vist at det forekommer både innfor koaktive idretter (f.eks. løping (stafett), cheerleading, svømming (stafett), roing, sykling; Anshel, 1995; Hardy \& Latané, 1988; Huddleston, Doody, \& Ruder, 1985; Høigaard, 2010; Høigaard, Boen, De Cuyper, \& Peters, 2013; Williams, Nida, Baca, \& Latané, 1989) og interaktive idretter (f.eks. håndball, fotball, ishockey; Høigaard, 2010; Høigaard et al., 2010; Høigaard \& Ommundsen, 2007).

Det er flere faktorer som kan bidra til sosial loffing, som blant annet manglende identifisering og evaluering av individuelle bidrag (Hardy \& Latané, 1988; Høigaard \& Ommundsen, 2007), gruppestørrelse (Ingham, Levinger, Graves, \& Peckham, 1974; Weinberg \& Gould, 2011), oppgavens verdi eller betydning for gruppemedlemmene (Karau \& Williams, 1993; Hardy \& Latané, 1988; Harkins \& Petty, 1982), forventing til andres innsats (Høigaard \& Ommundsen, 2007; Karau \& Williams, 1993) og verdsetting av gruppen (Høigaard et al., 2013; Høigaard, Tofteland, \& Ommundsen, 2006; Karau \& Hart, 1998; Karau \& Williams, 1995).

En faktor som både teoretisk og empirisk er relatert til sosial loffing, er kollektiv mestringstro (Bandura, 1997; Feltz, Short, \& Sullivan, 2008; Lichacz \& Partington, 1996). Dette defineres av Bandura (1997, s. 477) som 
"a group's shared belief in its conjoint capabilities to organize and execute the courses of action required to produce given levels of attainment». En rekke studier har dokumentert at det er en positiv sammenheng mellom kollektiv mestringstro og prestasjon (Feltz \& Lirgg, 1998; Gully, Incalcaterra, Joshi, \& Beaubien, 2002; Watson, Chemers, \& Preiser, 2001). I idrett har en også funnet tilsvarende positive relasjon i blant annet ishockey (Feltz \& Lirgg, 1998; Myers, Payment, \& Feltz, 2004), amerikansk fotball (Myers, Feltz, \& Short, 2004) og basketball (Watson et al., 2001). Samtidig viser disse studiene at sammenhengen er sirkulær, det vil si at teamprestasjon predikerer kollektiv mestringstro, som igjen predikerer teamprestasjon.

I eksperimentelle studier hvor deltakerne utfører fysisk krevende oppgaver, er det også dokumentert at kollektiv mestringstro påvirker prestasjonen. For eksempel viser studiene til Hodges og Carron (1992) og Bray (2004), hvor oppgaven var å holde en medisinball på strak arm så lenge som mulig, at deltakerne som var i grupper med høy kollektiv mestringstro, viste større utholdenhet (holdt medisinballen oppe lenger) enn de som var i grupper med lav mestringstro. I studien til Greenlees, Graydon og Mayard (1999) gjennomførte deltakerne tre sykkelforsøk i grupper. Før andre forsøk fikk gruppene falsk tilbakemelding på forutgående prestasjon for å påvirke deres kollektive mestringstro (høy kollektiv mestringstro: «Dere ligger svært nær den beste prestasjonen» - og lav kollektiv mestringstro: «Dere er blant de dårligste, og avstanden til teten er relativt stor»). Forut for siste sykkelforsøk fikk deltakerne en ny (falsk) tilbakemelding på at plasseringen ikke hadde endret seg. Resultatene viste at tilbakemeldingen påvirket mestringstroen signifikant, og at prestasjonen i gruppene med høy kollektiv mestringstro var signifikant bedre. Samtidig var det ikke signifikante prestasjonsforbedringer mellom de ulike forsøkene i gruppen med høy kollektiv mestringstro, mens det i gruppen med lav kollektiv mestringstro var en signifikant prestasjonsreduksjon mellom forsøk 1 og 3 . Selv om denne studien gir viktig informasjon om effekten av kollektiv mestringstro på prestasjon, kan en ikke avgjøre hvorvidt kollektiv mestringstro har effekt på innslaget av sosial loffing. Dette fordi studien ikke inkluderte noen individuell maksimal prestasjon som baseline (utgangspunkt). Basert på prestasjonsreduksjonen mellom forsøk 1 og 3 blant gruppen med lav kollektiv mestringstro kan man imidlertid foreslå 
at det har funnet sted sosial loffing. En studie som eksplisitt og eksperimentelt har undersøkt effekten av kollektiv mestringstro på innslaget av sosial loffing, er Lichacz og Partington (1996). I deres studie var oppgaven tautrekking, og graden av kollektiv mestringstro ble manipulert gjennom falsk feedback. Halvparten av lagene fikk høre at de lå under en «gitt prestasjonsstandard», og de andre fikk høre at de lå over denne standarden. Den falske feedbacken påvirket kollektiv mestringstro i tråd med antakelsene, og resultatene fra studien viste at grupper med høy kollektiv mestringstro hadde mindre innslag av sosial loffing enn gruppene med lavere grad av kollektiv mestringstro. Selv om det finnes eksperimentelle studier med relativt fysisk krevende oppgaver (holde en vekt/medisinball på strak arm samt tautrekking) som har undersøkt forholdet mellom kollektiv mestringstro og sosial loffing, har forskningen til nå i svært liten grad vært idrettsrelatert. Idrettsspesifikke oppgaver vil i større grad kunne oppleves som meningsfulle og motiverende for idrettsaktive deltakere, og det vil også kunne bidra en mer nyansert forståelse og anvendelse av fenomenene innenfor en idrettskontekst. Denne studien bygger derfor på arbeidene til Bray (2004), Greenlees et al. (1999) og Lichacz og Partington (1996), hvor det fokuseres på en idrettsrelevant oppgave (dvs. sykling).

På bakgrunn av det overnevnte er formålet med denne studien å undersøke i hvilken grad ulike typer falsk feedback (positiv feedback: informasjon om at de er blant de beste lagene i konkurransen, vs. negativ feedback: informasjon om at de er blant de dårligste lagene i konkurransen) påvirker lagenes kollektive mestringstro under en sykkelkonkurranse. Videre ønsker vi å undersøke i hvilken grad en eventuell endring i kollektiv mestringstro påvirker deltakernes innsats (dvs. sosial loffing). Følgende hypoteser for studien er utarbeidet:

1. Deltakerne vil redusere egen innsats (dvs. sosialt loffe) i en gruppekontekst hvor eget bidrag ikke blir identifisert, sammenlignet med innsatsen i en individuell identifisert konkurransekontekst.

2. Falsk positiv feedback (dvs. lagets prestasjon er blant de beste) vil bidra til økt kollektiv mestringstro, mens falsk negativ feedback (dvs. lagets prestasjon er blant de dårligste) vil bidra til redusert kollektiv mestringstro. 
3. Feedback (eksperimentell betingelse) vil indirekte påvirke innsatsen i en gruppekontekst hvor eget bidrag ikke blir identifisert, mediert av endring i grad av mestringstro.

\section{Metode}

\section{Utvalg}

Et bekvemmelighetsutvalg bestående av 66 idrettsstudenter (44 menn, 22 kvinner, gjennomsnittsalder $=21.2$ år, $s d=0.4)$ deltok i studien. Deltakerne trente i gjennomsnitt 5,3 økter per uke $(s d=2.8)$, og hver økt hadde en gjennomsnittlig varighet på 80 minutter $(s d=20)$. Åtte deltakere gjennomførte ikke hele eksperimentet som følge av sykdom, fravær og/eller skade (ikke relatert til eksperimentet). Disse ble ikke inkludert i de statistiske analysene (listwise deletion). Deltakelse i eksperimentet var frivillig, og alle deltakerne fylte ut en samtykkeerklæring før oppstart. Etter endt eksperiment ble alle informert om studiens hensikt og gitt mulighet for å trekke sitt bidrag. Ingen trakk seg fra studien. Studien er godkjent av Etisk komité ved Universitetet i Agder.

\section{Prosedyre}

Deltakerne gjennomførte en ett minutts sykkeltest fire ganger under ulike eksperimentelle betingelser (ITT - individuelt forsøk, TT1 - lagforsøk 1, TT2 - lagforsøk 2, TT3 - lagforsøk 3). Første forsøk ble gjennomført i grupper på fire, hvor individuell innsats ble identifisert og offentliggjort til hver enkelt (se Familisering). I lagforsøkene ble deltakerne informert om at kun lagprestasjon ble registrert (individuell prestasjon ble likevel registrert). Forut for lagforsøkene ble deltakerne randomisert inn i lag (tre-seks deltakere per lag) og i to feedback-kategorier (positiv eller negativ). For de lagene som fikk positiv feedback, ble følgende beskjed gitt i forkant av andre lagforsøk: «Dere ligger nå blant de to beste lagene», og i forkant av siste lagforsøk: «Dere ligger fortsatt blant de to beste lagene, og avstanden til de andre er uforandret». For de lagene som fikk negativ feedback, ble følgende beskjed gitt før andre lagforsøk: «Dere ligger nå blant 
de to dårligste lagene», og i forkant av siste lagforsøk: «Dere ligger fortsatt blant de to dårligste lagene, og avstanden til de andre er uforandret».

Deltakerne gjennomførte en ti minutters selvstyrt oppvarming før hver sykkeltest, og det var 45 minutters restitusjonstid mellom hvert lagforsøk, inkludert ny oppvarming. Forsøkspersonene ble bedt om å holde en selvregulert maksimal innsats i hver test, og ble informert om at gjennomsnittlig wattproduksjon i hver test ville bli registrert. Testene ble startet med pedalene i horisontal posisjon. Testleder begynte en nedtelling fra tre før startsignal ble gitt. Verbal tilbakemelding om gjenværende tid ble gitt hvert 15. sekund.

\section{Familisering}

I forkant av studien ble det gjennomført en familiseringsdag, hvor deltakerne først fikk informasjon om hvordan forsøkene skulle gjennomføres. I tillegg ble det gitt en dekkhistorie omkring studien for ikke å avsløre hva som var intensjonen med den. Dekkhistorien gav inntrykk av at studien skulle avdekke fysiologiske forskjeller ved maksimalt arbeid. Det ble presisert at resultatene skulle brukes i undervisning samt forskningsarbeid. Videre valgte deltakerne en sykkel ut fra kroppshøyde og justerte setehøyden etter egne preferanser, for deretter å prøve å sykle og finne et gir som gav riktig/passende motstand. Deltakernes individuelle innstillinger av sykler og valg av gir ble registrert for videre bruk i de påfølgende forsøkene. Familiseringsdagen ble avsluttet med en individuell ti minutters oppvarming og en individuell ett minutts test (ITT), hvor deltakerne ble informert om at den enkeltes prestasjon ville bli registrert og offentliggjort etter prosjektslutt.

\section{Sykkeltest}

Alle forsøkene ble gjennomført på CompuTrainer Lab-ruller (Racer Mate, Seattle, WA, USA) med Nakamura 3.o sykkelmodeller. Ergometerrullene var datastyrt gjennom programvaren RaceMate One, som styrte motstanden i rullene gjennom elektronisk brems. Det er vist at CompuTrainer Lab-rullene har en konstant belastning over et bredt belastningsspekter med en nøyaktighet på $\pm 2.5 \%$ med en repeterbarhet innenfor $1 \%$ (Racer 
Mate, Seattle, WA, USA). I forkant av hvert forsøk ble rullemotstanden kalibrert ved en roll down resistance-prosedyre, hvor hjulmotstanden ble kalibrert til mellom 3.50 og 4.00 pund. Kalibreringsverdien ble lagret for den enkelte sykkel og brukt til å beregne gjennomsnittswatt gjennom maksimaltesten.

Gjennomsnittswatt ble benyttet som mål på innsats; det vil si at høyere watt produsert indikerer bedre innsats. Forsøkene ble gjennomført ved en romtemperatur på mellom $20^{\circ}$ og $22^{\circ} \mathrm{C}$. En reliabilitetsstudie (Haugen, Salvesen, \& Høigaard, 2018) har vist at protokollen innehar en tilfredsstillende test-retest-reliabilitet og god evne til å produsere nøyaktige og stabile målinger over tid.

\section{Målinger \\ Mestingstro}

Før første lagforsøk (TT1) og etter at feedback ble gitt i forsøk 2 (TT2) og 3 (TT3), vurderte hver deltaker hvor stor tro (sannsynlighet) de hadde på at laget kunne vinne (bli best) i neste forsøk. Spørsmålet ble besvart på en skala fra o\% (ingen tro på å vore best / vinne) til 100\% (sikker på å vore best / vinne).

\section{Sosial loffing}

I denne studien ble sosial loffing definert som en signifikant reduksjon i gjennomsnittswatt oppnådd på lagtest sammenlignet med individuell test. Denne operasjonaliseringen har blitt brukt i flere tidligere idrettspsykologiske eksperimenter (f.eks. Haugen, Reinboth, Hetlelid, Peters, \& Høigaard, 2016; Høigaard, Tofteland, \& Ommundsen, 2006; Nilsen, Haugen, Reinboth, Peters, \& Høigaard, 2014).

\section{Innstilling til deltakelse}

Etter at alle forsøkene var gjennomført, skulle deltakerne ta stilling til henholdsvis 1: «Hvor seriøs har din deltakelse i prosjektet vort?» på en skala fra 1 (Svort useriøs) til 5 (Svoert seriøs), og 2: «Hvor mye innsats har du lagt ned sykkelforsøkene?» på en skala fra 1 (Svoert lite innsats) til 5 (Svoert stor innsats). 


\section{Statistiske analyser}

De statistiske analysene ble utført i SPSS versjon 24.0 (SPSS, Chicago, IL, USA). Kontinuerlige data ble på bakgrunn av histogram, Q-Q-plot, kurtosis- og skewnessverdier samt differanse mellom gjennomsnitt og median ansett som tilfredsstillende normalfordelt, og derfor presentert i tekst- og figurform ved gjennomsnitt $(m)$ og standardavvik $(s d)$ og analysert ved hjelp av parametriske analyser. Endring i wattproduksjon over fire forsøk ble analysert ved hjelp av repeated measures ANOVA. To-faktor ANOVA med gruppe (positiv feedback vs. negativ feedback) som eksperimentell betingelse og forsøk (repeterte sykkeltester) som repetert måling ble brukt for å undersøke gruppeforskjeller i innsats. Partial eta squared blir oppgitt for ANOVA-tester som mål på effektstørrelse. Tradisjonelt vil verdier fortolkes som $\sim .01=$ liten, $\sim .06=$ middels, og .14 = stor (Cohen, 1988). For å teste hypotese 3, potensiell indirekte effekt (mediasjonsmodellen), ble Preacher og Hayes' (og kolleger; Preacher \& Hayes, 2004, 2008; Preacher, Rucker, \& Hayes, 2007) makro INDIRECT for IBM SPSS brukt. I tillegg til «normale» regresjonsprosedyrer gir makroen bootstrap-genererte punktestimater, standardavvik for estimatene og bias-korrigerte konfidensintervaller av den indirekte effekten. Et konfidensintervall som ikke inneholder null, vil indikere statistisk signifikant indirekte effekt. Alpha-verdien ble satt til .05 for alle analyser.

\section{Resultater}

Innstillingen til deltakelse i studien ble rapportert som relativt seriøs: På spørsmål 1, «Hvor seriøst har din deltakelse i prosjektet vært?», svarte over $80 \%$ av deltakerne «seriøst» (4) eller «svært seriøst» (5). Ingen av deltakerne svarte «svært useriøst» (1). På selvrapportert innsats under de ulike testene svarte $96 \%$ av deltakerne «stor innsats» (4) eller «svært stor innsats» (5). De resterende 4\% svarte «verken stor eller liten innsats» (3). For utvalget som helhet identifiserte en repeated measures ANOVA at det forekom sosial loffing; en signifikant reduksjon i innsats $(F(3,55)=10.68$, $p<.01$, partial eta ${ }^{2}=.37$ ) fra individuell test (ITT; $m(s d)=445.9(92.88)$ ) til 
gruppetestene (TT1; 424.9(87.26), TT2; (415.6(90.92) og TT3; 417.9(100.61)). Det var i tillegg en signifikant reduksjon fra TT1 til TT2. Det var ingen reduksjon i innsats fra $\mathrm{TT}_{2}$ til $\mathrm{TT}_{3}$.

For å undersøke eventuell endring i mestringstro på bakgrunn av positiv og negativ feedback ble en 2 (gruppe: positiv tilbakemelding vs. negativ tilbakemelding) x 3 (repeterte sykkelforsøk) faktor ANOVA gjennomført. Resultatet viste en signifikant interaksjonseffekt mellom tilbakemelding og repeterte målinger på individenes tro på gruppens seiersmuligheter $\left(F_{(\mathrm{df})}=7.76_{(2)}, p<.001\right.$, partial eta $\left.{ }^{2}=.22\right)$. Som illustrert i figur 1 hadde deltakerne som mottok positiv feedback en økning i mestringstro (1. forsøk: $62.8 \%, 2$. forsøk: $66.2 \%, 3$. forsøk: $70.3 \%)$, mens deltakerne som mottok negativ feedback reduserte sin mestringstro (1. forsøk: 59.3\%, 2. forsøk: 48.7\%, 3. forsøk: 39.0\%).

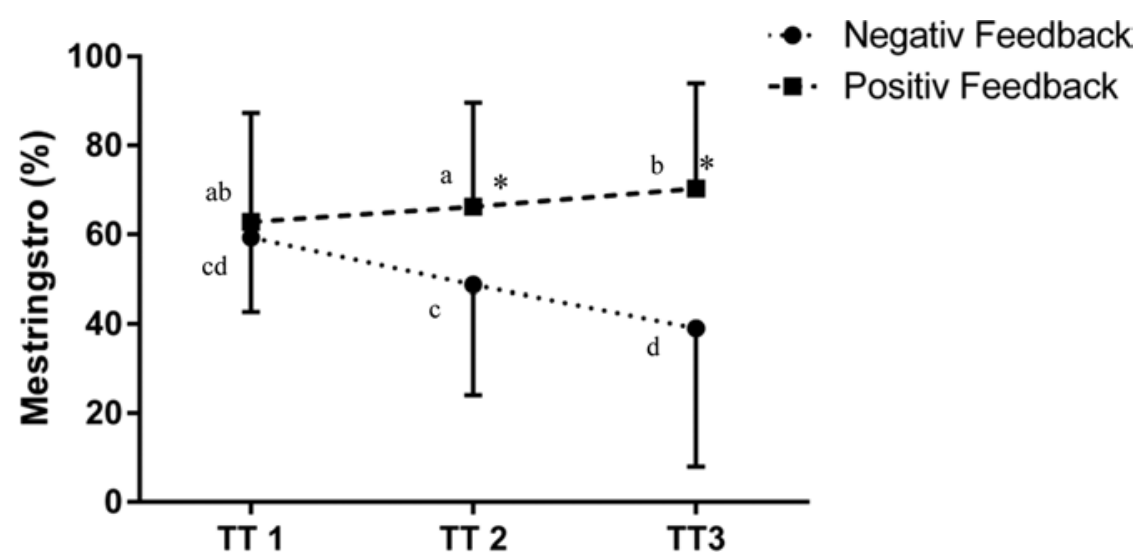

Figur 1. Score på mestringstro i forkant av teamtester, på bakgrunn av feedback. Note. *Signifikant forskjell mellom gruppene $(p<.01)$ på TT 2 og TT 3. Signifikant interaksjonseffekt $\left(F(d f)=7.76_{(2)}, p<.001\right.$, partial eta $\left.{ }^{2}=.22\right) .{ }^{\text {a-d }}$ Lik bokstav indikerer signifikant $(p<.01)$ forskjell mellom tester.

En 2 (gruppe: positiv tilbakemelding vs. negativ tilbakemelding) x 4 (repeterte sykkelforsøk) faktor ANOVA ble utført for gjennomsnittswatt ved forsøkene på ett minutt. Det ble ikke funnet noen signifikant interaksjonseffekt mellom tilbakemelding og forsøk på deltakernes gjennomsnittswatt $\left(\left(F_{(d f)}=0.38_{(1)}, p=.38\right)\right.$. Videre var det ingen signifikante forskjeller mellom gruppene på noe tidspunkt (se figur 2). 


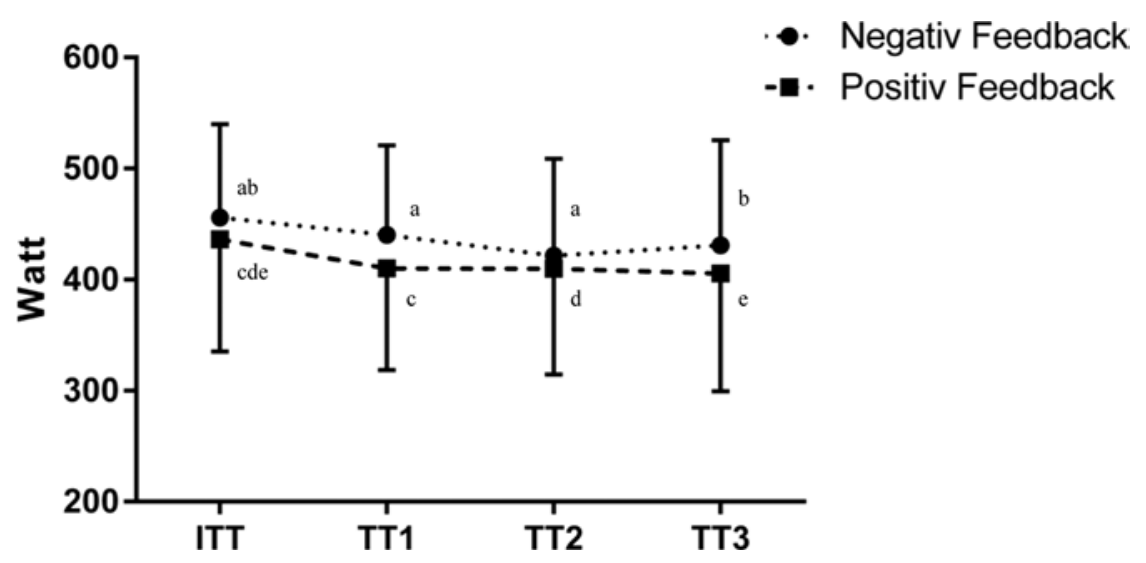

Figur 2. Prestasjon (i watt) for individuell test og lagtester på bakgrunn av feedback.

Note. ${ }^{a-e}$ Lik bokstav indikerer signifikant forskjell fra test til test (innad i grupper). Ingen signifikant forskjell mellom gruppene på noe tidspunkt, og ingen interaksjonseffekt $\left(F(d f)=0.38_{(1)^{\prime}} p=.38\right)$.

Som vist i figur 3 var det ingen effekt av feedback på endring i innsats på bakgrunn av endring i mestringstro. Det var ingen signifikant total effekt av feedback på innsats (verken ved TT2 eller $\mathrm{TT}_{3}$ ) og heller ingen signifikant effekt av mestringstro på innsats. Hypotese 3 (dvs. feedback (eksperimentell betingelse) vil indirekte påvirke innsats i en gruppekontekst hvor eget bidrag ikke blir identifisert, mediert av endring i grad av mestringstro) ble med andre ord ikke bekreftet $i$ analysene.

\section{Diskusjon}

Formålet med studien var tredelt. For det første ønsket vi å undersøke om manglende identifisering av individuell innsats i et team bidro til økt sosial loffing. For det andre ville vi undersøke om kollektiv mestringstro ble påvirket av ulike typer feedback (positiv og negativ), og for det tredje i hvilken grad feedback indirekte påvirket deltakernes innsats (sosial loffing) gjennom kollektiv mestringstro i en lagkonkurranse på sykkel.

Resultatene viste at deltakerne reduserte sin innsats da individuelt bidrag ikke ble identifisert, sammenlignet med identifisert individuell innsats (dvs. sosial loffing). Dette resultatet bekrefter hypotese 1, og resultatet er også i tråd med tidligere forskning (Høigaard, 2008; 2010; 
Indirekte effekt

P.E. $=1.44^{\mathrm{ns}}$

a

(BC 95\% CI: [-12.67, 11.44])

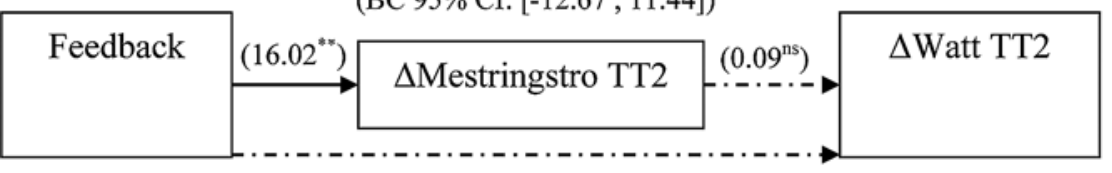

Total effekt $\left(-4.26^{\mathrm{ns}}\right)$

Direkte effekt $\left(-5.07^{\mathrm{ns}}\right)$

Total effekt $\left(8.00^{\text {ns }}\right)$

b Direkte effekt $\left(13.88^{\text {ns }}\right)$

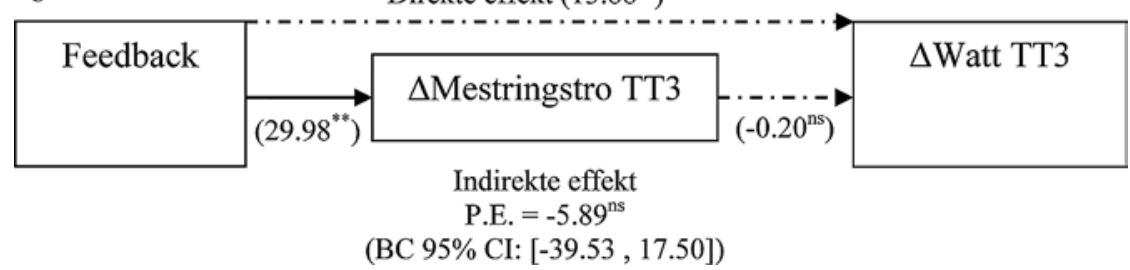

Figur 3. Testing av indirekte effekt av feedback på endring i innsats (watt) gjennom endring i mestringstro, for henholdsvis TT2 (a) og TT3 (b).

Note. Feedback = dikotom gruppering, på bakgrunn av feedback ( $0=$ negativ, $1=$ positiv $)$; TT2 = lagforsøk 2; TT3 = lagfors øk 3; $\Delta$ Mestringstro TT2 = endring i mestringstro fra lagfors øk 1 til lagfors $ø \mathrm{k} 2(\mathrm{TT} 2-\mathrm{TT} 1) ; \Delta$ Mestringstro TT3 = endring $\mathrm{i}$ mestringstro fra lagfors $ø \mathrm{k} 1$ til lagfors $ø \mathrm{k}$ 3 (TT3-TT1); $\Delta$ Watt TT2 = endring i wattproduksjon fra individuelt fors $ø \mathrm{k}$ til lagfors $ø \mathrm{k}$ $2($ TT2 - ITT); $\Delta$ Watt TT3 = endring $\mathrm{i}$ wattproduksjon fra individuelt fors $ø \mathrm{k}$ til lagfors $ø \mathrm{k}$ 3 (TT3-ITT). Heltrukne linjer indikerer signifikante regresjonskoeffisienter; ns = ikke signifikant; ${ }^{\star \star}=$ statistisk signifikant $(p<.01)$.

Karau \& Williams, 1993; 1995; Williams et al., 1989). Dette innebærer at eksperimentet lyktes i å skape en betingelse hvor sosial loffing oppstod.

Resultatene viste videre at positiv feedback (informasjon om at laget er blant de beste i konkurransen) bidro til økt kollektiv mestringstro, og at negativ feedback (informasjon om at laget er blant de dårligste i konkurransen) bidro til redusert kollektiv mestringstro, noe som støtter hypotese 2. Samtidig viste resultatene ingen dokumentasjon på forskjell i graden av sosial loffing på bakgrunn av feedback (figur 2). Mediasjonsanalysen (figur 3) viste heller ingen indirekte effekt (gjennom mestringstro) av feedback på innsats. Disse funnene innebærer at hypotese $3 \mathrm{i}$ denne studien ikke ble bekreftet.

At feedback direkte knyttet til tidligere prestasjon(er) påvirker deltakernes kollektive mestringstro, er godt teoretisk og empirisk underbygget 
(Bandura, 1997; Bray, 2004; Feltz et al., 2008; Myers et al., 2004; Høigaard, 2008; Watson et al., 2001). Forskning har også vist at feedback som verbal overtalelse og peptalk kan ha en positiv effekt på kollektiv mestringstro. For eksempel har Vargas-Tonsing og Bartholomew (2006) undersøkt hvordan ulikt innhold i peptalk i forkant av en konkurranse påvirket utøverens kollektive mestringstro. Deltakerne ble i denne studien delt i tre grupper som ble eksponert for følgende type peptalk: 1) Informasjon og kontroll (dvs. hvordan drakten skal være, og hvordan en skal marsjere inn på banen, samt informasjon om hvordan opprettholde væskebalansen); 2) Strategisk/taktisk (dvs. informasjon om mostanderlagets styrker og svakheter samt hva en bør gjøre for å «slå» motstanderne); og 3) Overbevisende appell (dvs. en emosjonell appell for å skape tro på at laget skal lykkes). Resultatene viste at det kun var deltakerne i gruppe 3 som rapporterte høyere mestringsforventning etter peptalken (Vargas-Tonsing \& Bartholomew, 2006).

Mer overraskende og mindre i tråd med teorien (Bandura 1997; Feltz et al., 2008; Høigaard, 2008) er det at kollektiv mestringstro ikke innvirket på innsats og (derav) heller ikke på innslaget av sosial loffing. Feltz og kolleger (2008) fremhever at kollektiv mestringstro påvirker hva personer gjør i en gruppe, hvor mye innsats den enkelte vil bidra med for å utføre oppgaven, og hvor utholdende de er når gruppen møter motstand eller presterer dårlig. Denne effekten av kollektiv mestringstro er tidligere dokumentert i både feltstudier og eksperimenter/laboratoriestudier (for en oversikt, se Feltz et al., 2008). Det at mestringstro i denne studien ikke innvirket på innsats og prestasjon (det vil si reduserte innslaget av sosial loffing), kan kanskje knyttes til selve feedbacken som ble gitt. Den bestod av kort informasjon om plassering (blant de beste/dårligste) i konkurransen. Selv om tilsvarende feedback er benyttet i andre studier (f.eks. Greenlees et al., 1999), hevder Bandura (1997) at en tidligere prestasjon i seg selv kanskje ikke er en pålitelig indikator for fremtidige prestasjoner. Til tross for at deltakernes vurdering av mestringstro ble påvirket av feedback, kan det antas at en trenger flere mestringserfaringer over tid før for den bidrar betydelig til atferdsendring. Kanskje er også en form for kognitiv bearbeiding og refleksjon en nødvendig forutsetning for at motivasjon og 
teamprosesser knyttet til mestringstro skal bidra til økt innsats og prestasjon (Bandura, 1997; Bray, 2004; Høigaard, 2008).

Et annet forhold er at selv om «tidligere prestasjoner» ofte knyttes til innsats i konkurranse (som i denne studien), fremhever Bandura (1997) at mestringsopplevelser er mer komplekse, og at suksess og mestring som en opplever under trening, er mer selvbestemt og invariant enn det en opplever i en konkurranse. Dette understøttes av Feltz og Lirgg (1998) i en studie av ishockeyspillere som oftere refererte til tidligere prestasjoner under trening enn til prestasjoner i kampene som kilde til kollektiv mestringstro.

Ethvert vitenskapelig eksperiment inneholder sterke og svake sider, så også denne studien. Ett aspekt er at det strengt kontrollerte studiedesignet kan redusere overførbarheten til praksisfeltet. Feltz et al. (2008) viser til at det kan være flere avgjørende forskjeller mellom eksperimentelle studier under kontrollerte forhold og feltundersøkelser. Den ene er at gruppene som dannes ved eksperimentelle laboratorieundersøkelser, ofte er mer eller mindre fremmede overfor hverandre og kun har studienes oppgave som felles mål. Dette står i kontrast til etablerte idrettsgrupper, hvor deltakerne ofte har innarbeidet et samhold, en kommunikasjon og en rollefordeling over lengre tid, og dermed vil føle større ansvar for lagets prestasjoner (Carron, Hausenblas, \& Eys, 2005). I tillegg til en annen gruppesammensetning er oppgavetypene ulike ved laboratorie- og feltstudier.

Videre kan det hevdes at studier gjennomført i laboratorium, hvor de fleste oppgavene er koaktive, står i kontrast til studier gjennomført i felt (hovedsakelig basert på interaktive oppgaver). Ved interaktive oppgaver får hver deltaker et mer synlig ansvar for prestasjonen, og da økes eller opprettholdes den gjerne i større grad enn ved koaktive oppgaver (Feltz et al., 2008). På bakgrunn av dette bør generaliserbarheten av studiens funn vurderes i lys av aspekter som oppgavetype, ferdighetsnivå, gruppekarakteristika og idrettskontekst.

\section{Avslutning}

Resultatene fra denne studien følger opp tidligere forskning, men baner også vei for videre forskning på kollektiv mestringsforventning. Selv om 
deltakernes kollektive mestringsforventning ble påvirket av positiv og negativ feedback, kan en avslutningsvis stille seg spørsmålet om hvorvidt tilbakemelding på bakgrunn av lagets plassering er en stor nok påvirkning til å kunne ha effekt på deltakernes atferd - i form av innsats i en fysisk krevende oppgave. Basert på at deltakerne presterte likt, til tross for at det ble rapportert om ulik kollektiv mestringsforventning, kan det ikke bekreftes at kollektiv mestringsforventning påvirker graden av sosial loffing. Det kan hende at kollektiv mestringsforventning er en mer underliggende faktor for gruppeprestasjon, og at det krever tid og refleksjon for å oppnå en prestasjonsforandring. I den videre forskningen vil det være interessant å se hvorvidt ulik type feedback (for eksempel verbal tilbakemelding med mål om å påvirke deltakernes psykologiske og affektive tilstand, eller en visuell tilbakemelding gjennom resultattavle med prestasjonsverdier) kan påvirke innsatsen i større grad. Tidsaspektet ved denne tilbakemeldingen kan også være avgjørende for en mulig atferdsforandring, der refleksjon eller grundigere overveielser av mestringsforventning spiller en større rolle.

\section{Referanser}

Anshel, M.H. (1995). Examining social loafing among elite female rowers as a function of task duration and mood. Journal of Sport Behavior, 18, 39-49.

Bandura, A. (1997). Self-efficacy: The exercise of control. New York, NY: Freeman.

Bray, S.R. (2004). Collective efficacy, group goals, and group performance of a muscular endurance task. Small Group Research, 35, 230-238.

Carron, A.V., Hausenblas, H.A., \& Eys, M.A. (2005). Group dynamics in sport. Morgantown, WV: Fitness Information Technology.

Cohen, J. (1988). Statistical power analysis for the behavioral sciences (2nd ed.). Hillsdale, NJ: Erlbaum.

Cohen, S.G., Ledford, G.E., \& Spreitzer, G.M. (1996). A predictive model of selfmanaging work team effectiveness. Human Relations, 49, 643-676.

Feltz, D.L. \& Lirgg, C.D. (1998) Perceived team and player efficacy in hockey. Journal of Applied Psychology, 83, 557-564.

Feltz, D.L., Short, S.E., \& Sullivan, P.J. (2008). Self-efficacy in sport. Research and strategies for working with athletes, teams, and coaches. Champaign, IL: Human Kinetics. 
Gully, S.M., Incalcaterra, K.A., Joshi, A., \& Beaubien, J. (2002). A meta-analysis of the team-efficacy, potency, and performance: Interdependence and level of analysis as moderators of observed relationships. Journal of Applied Psychology, 87, 819-832.

Greenlees, I.A., Graydon, J.K., \& Maynard, I.W. (1999). The impact of collective efficacy beliefs on effort and persistence in a group task. Journal of Sports Sciences, $17,151-158$.

Hardy, C.J. \& Latané, B. (1988). Social loafing in cheerleaders: Effects of team membership and competition. Journal of Sport and Exercise Psychology, 10, 109-114.

Harkins, S.J. \& Petty, R.E. (1982). Effects of task difficulty and task uniqueness on social loafing. Journal of Personality and Social Psychology, 43, 1214-1229.

Hodges, L. \& Carron, A.V. (1992). Collective efficacy and group performance. International Journal of Sport Psychology, 23, 48-59.

Huddleston, S., Doody, S.G., \& Ruder, M.K. (1985). The effect of prior knowledge of the social loafing phenomenon on performance in a group. International Journal of Sport Psychology, 16, 176-182.

Haugen, T., Reinboth, M., Hetlelid, K.J., Peters, D.M., \& Høigaard, R. (2016). Mental toughness moderates social loafing in cycle time-trial performance. Research Quarterly for Exercise and Sport, 87, 305-310.

Haugen, T., Salvesen, K.M.U., \& Høigaard, R. (2018). Reliabilitetstest av maksimal prestasjon på sykkelrulle med ett minutts varighet. I T. Haugen \& R. Høigaard (red). Trender i idrettspsykologisk forskning i Skandinavia (Kap. 11, s. 225-238). Kristiansand: Cappelen Damm Akademisk.

Høigaard, R. (2008). Gruppedynamikk i idrett. Kristiansand: Høyskoleforlaget.

Høigaard, R. (2010). Social loafing in sport: From theory to practice. Saarbrücken, Germany: VDM Verlag Dr. Müller Aktiengesellschaft \& Co.

Høigaard, R., Boen, F., De Cuyper, B., \& Peters, D.M. (2013). Team Identification Reduces Social Loafing and Promotes Social Laboring in Cycling. International Journal of Applied Sports Sciences, 25, 33-40.

Høigaard, R., Fuglestad, S., Peters, D.M., De Cuyper, B., De Backer, M., \& Boen, F. (2010). Role satisfaction mediates the relation between role ambiguity and social loafing among elite woman handball players. Journal of Applied Sport Psychology, 22, 408-419.

Høigaard, R. \& Ommundsen, Y. (2007). Perceived social loafing and anticipated effort reduction among young football (soccer) players: an achievement goal perspective. Psychological Report, 100, 857-875.

Høigaard, R., Tofteland, I., \& Ommundsen, Y. (2006). The Effect of Team Cohesion on Social Loafing in Relay Teams. International Journal of Applied Sports Sciences, 18, 59-73. 
Ingham, A.G., Levinger, G., Graves, J., \& Peckham, V. (1974). The Ringelmann effect: Studies of group size and group performance. Journal of Experimental Social Psychology, 10, 371-384.

Karau, S.J. \& Williams K.D. (1993). Social loafing: A meta-analytic review and theoretical integration. Journal of Personality and Social Psychology, 65, 681-706.

Karau, S.J. \& Williams K.D. (1995). Social Loafing: Research findings, implication and future directions Current Directions in Psychological Science, 41, 34-149.

Karau, S.J. \& Hart, J.W. (1998). Group cohesiveness and social loafing: Effects of a social interaction manipulation on individual motivation within group. Group Dynamics: Theory, Research, and Practice, 2, 185-191.

Lichacz, F.M. \& Partington, J.T. (1996). Collective efficacy and true group performance. International Journal of Sport Psychology, 27, 146-158.

Myers, N.D., Feltz, D.L., \& Short, S.E. (2004). Collective Efficacy and Team Performance: A Longitudinal Study of Collegiate Football Teams. Group Dynamics: Theory, Research, and Practice, 8(2), 126-138.

Myers, N.D., Payment, C.A., \& Feltz, D.L. (2004). Reciprocal relationships between collective efficacy and team performance in women's ice hockey. Group Dynamics: Theory, Research, and Practice, 8, 182-195.

Nilsen, T., Haugen, T., Reinboth, M., Derek, P.M., \& Høigaard, R. (2014). Explicit prior knowledge of social loafing in subsequent team cycle trail performance. Kinesiologia Slovenica, 20, 17-25.

Prapavessis, H., \& Carron, A.V. (1997). Cohesion and Group output. Small Group Research, 28, 294-301.

Preacher, K.J. \& Hayes, A.F. (2004). SPSS and SAS procedures for estimating indirect effects in simple mediation models. Behavior Research Methods, Instruments, \& Computers, 36(4), 717-731.

Preacher, K.J. \& Hayes, A.F. (2008). Asymptotic and resampling strategies for assessing and comparing indirect effects in multiple mediator models. Behavior Research Methods, 40(3), 879-891.

Preacher, K.J., Rucker, D.D., \& Hayes, A.F. (2007). Addressing moderated mediation hypotheses: Theory, methods, and prescriptions. Multivariate Behavioral Research, 42(1), 185-227.

Ringelmann, M. (1913). Research on animate sources of power: The work of man. Annales de l'Instuit National Agronomique, 12, 1-40.

Vargas-Tonsing, T.M. \& Bartholomew, J.B. (2006). An exploratory study of the effects of pregame speeches on team efficacy beliefs. Journal of Applied Social Psychology, 36, 918-933.

Watson, C.B., Chemers, M.M., \& Preiser, N. (2001). Collective efficacy: A multilevel analysis. Personality and Social Psychology Bulletin, 27, 1057-1068. 
Weinberg, R.S. \& Gould, D. (2011). Foundations of sport and exercise psychology. Fifth edition Champaign: Human Kinetics.

Wellins, R.S., Byham, W.C., \& Dixon, G.R. (1994). Inside teams: How 20 world-class organizations are winning through teamwork. San Francisco, CA: Jossey-Bass.

Williams, K.D., Nida, S.A., Baca, L.D., \& Latané, B. (1989). Social loafing and swimming: Effects of identifiability on individual and relay performance of intercollegiate swimmers. Basic and Applied Social Psychology, 10, 73-81. 



\section{Om bidragsyterne}

Frank E. Abrahamsen (f.e.abrahamsen@nih.no) har en ph.d. i idrettspsykologi fra Norges idrettshøgskole (2007), der han jobber i dag. Han har tidligere jobbet over ti år for Olympiatoppen og har jobbet med over femti landslag i idrett, samt andre prestasjonsgrupper som kokkelandslagene og Forsvaret. Han er derfor svært interessert i psykologiske emner rundt topprestasjoner og forsker på både utøvere og trenere. Tema for publiseringer de siste årene har typisk vært motivasjon, stress og lederskap.

Astrid Becker-Larsen (abecker-larsen@health.sdu.dk) er uddannet cand. scient. i Idræt og Sundhed fra Syddansk Universitet (2016). Hun er ansat som videnskabelig assistent i forskningsenheden LET'S - Learning and Talent in Sport, hvor hun underviser og forsker indenfor emnerne talentudvikling, sportspsykologi, teamudvikling, mental stress og genopladning. Hun er tilknyttet Team Danmarks eksterne netværk af sportspsykologiske konsulenter samt næstformand i DIFO - Dansk Idrætspsykologisk Forum, der har til formål at udbrede og udvikle sportspsykologi i Danmark.

Martin Kjeøen Erikstad (martin.erikstad@uia.no) er ansatt som doktorgradsstipendiat ved Institutt for folkehelse, idrett og ernæring ved Universitetet i Agder. Han har i tillegg undervisningsplikt innen fagene idrettspsykologi, statistikk og metodelære samt praktiske aktiviteter. Han er medlem av forskningsgruppa SEP-HEP (Sport and Exercise Psychology: Health, Education and Performance) og gjennomfører sitt ph.d.-arbeid på Assist-prosjektet, som er et forskningsprosjekt på spillerutvikling i fotball.

Harald S. Gaard (sylfesten@me.com) har pedagogisk utdanning og mastergrad i idrettsvitenskap fra Universitet i Agder (2016). Han har UEFA-B lisens (NFF), er hovedtrener for Kongsberg IF (a-lag, fotball) og jobber som lektor ved Tislegård ungdomsskole. 
Rune Giske (rune.giske@uis.no) er dr.scient. i idrettsvitenskap. Han jobber for tiden som førsteamanuensis ved Universitetet i Stavanger og underviser i idrettspsykologi, ballspill, motorisk læring og coaching på ulike studienivåer. Han har lang erfaring som håndballtrener og ungdomstrener i fotball. I tillegg er Rune tilknyttet Olympiatoppen Sørvest som idrettspsykologisk rådgiver.

Joar Gjerde (joargjerde@gmail.com) har pedagogisk utdanning og mastergrad i idrettsvitenskap fra Universitetet i Stavanger (2015). Han er tidligere elitespiller i håndball og har mastercoach-utdanning fra NHF/EHF, er hovedtrener for Viking HK (A-lag håndball), og er trener for juniorlandslaget LM98. Jobber også som lektor ved St. Svithun VGS.

Tommy Haugen (tommy.haugen@uia.no) er utdannet allmennlærer fra Høgskolen i Sogn og Fjordane (2002), og med mastergrad i idrettsvitenskap (2005) fra Høgskolen i Agder. Han har en ph.d.-grad i idrettsvitenskap (2013) fra Norges idrettshøgskole. Jobber for tiden som førsteamanuensis ved Universitetet i Agder, med undervisning, forskning og veiledning innen tema som barn og unges utvikling, helseatferd, idrettsdeltakelse og mental helse, motivasjonspsykologi og idrettslig prestasjon.

Kristoffer Henriksen (khenriksen@health.sdu.dk) er uddannet psykolog fra Århus Universitet (2001). Han er ansat som lektor i talentudvikling og ph.d i sportspsykologi ved Syddansk Universitet og forskningsleder for forskningsenheden LETS - Learning and Talent in Sport. I tillæg er han ansat som sportspsykologisk konsulent i Team Danmark. Her hjælper han danske atleter og trænere med at trives, opbygge mental styrke og præstere under pres. Han har fulgt danske atleter til adskillige mesterskaber, herunder to gange de Olympiske Lege.

Jørgen Holmemo (holmemo@gmail.com) har en mastergrad i idrettsvitenskap fra Seksjon for coaching og psykologi ved Norges idrettshøgskole. Han skrev masteroppgave om norske elitetreneres forhold til sine overordnede og underordnede i 2015. Han jobber i dag som personlig trener og mental trener. 
Carsten Hvid Larsen (chlarsen@health.sdu.dk) er cand.scient. i idræt, European Master i Sport and Exercise Psychology og Ph.D indenfor talentudvikling og sportspsykologi. Han er ansat halvtid som studielektor i talentudvikling og sportspsykologi ved Syddansk Universitet i forskningsenheden LETS - Learning and Talent in Sport. I resten af tiden arbejder han som sportspsykologisk konsulent i Team Danmark, hvor han hjælper trænere og atleter med at håndtere pres, udvikle mental sundhed og støtter udviklingen af højtydende teams. Han arbejder med atleter der har deltaget i EM, VM og OL.

Per-Mathias Høgmo (per-mathias.hogmo@uit.no) er utdannet adjunkt fra Lærerhøgskolen i Tromsø. Han har i tillegg mellom- og hovedfag fra Norges idrettshøgskole (NIH). Hans pågående doktorgradprosjekt ved UIT omhandler prestasjonskultur i organisasjoner. Han har jobbet som topptrener og leder på øverste nivå både nasjonalt og internasjonalt. Høgmo jobber for tiden som manager i Fredrikstad Fotballklubb.

Rune Høigaard (rune.hoigaard@uia.no) er professor ved Institutt for folkehelse, idrett og ernæring, Fakultet for helse- og idrettsvitenskap, Universitetet i Agder (UiA) og professor II ved Seksjon for idrett ved Nord Universitet, Bodø. Han har en doktorgrad i idrettsvitenskap fra NTNU, der hovedtema var prestasjoner i idrettsgrupper. I tillegg er han leder av forskningsgruppen Sport and Exercise Psychology (SEP-HEP) ved UiA og fagansvarlig for idrettspsykologi ved Olympiatoppen Sør. Han har publisert en rekke vitenskapelige artikler og bøker innfor idrettspsykologi, gruppedynamikk, veiledning og coaching.

Kazuma Ishimatsu (k-ishimatsu@ghsj.ac.jp) er professor i nevropsykologi, og jobber som veileder og forsker på endringer i oppmerksomhet, eksekutiv funksjon og atferd ved økt alder. Han tok sin ph.d.-grad i Human Sciences ved Osaka University i 2004 (Tittel: "Visual Attention and Ageing”). Hans pågående forskning omhandler metakognisjon, post-error-kontroll og menneskelige faktorer i helseforetak. Ishimatsu har hatt et forskningssamarbeid med Flymedisinsk institutt de siste seks årene. 
Andreas Ivarsson (andreas.ivarsson@hh.se) arbetar som universitetslektor i psykologi inriktning idrott, hälsa, och motion vid Högskolan i Halmstad. Andreas disputerade vid Linnéuniversitetet med en avhandling som handlar om idrottsskadans psykologi. Han arbetar även som idrottspsykologisk rådgivare där han framförallt har arbetat med klienter från fotboll och handboll.

Bjørn Tore Johansen (bjorn.t.johansen@uia.no) er dr.scient. i idrettspsykologi fra Norges idrettshøgskole og ansatt som førsteamanuensis ved Institutt for folkehelse, idrett og ernæring ved Universitetet i Agder. Han har lang erfaring med undervisning og veiledning på høgskole- og universitetsnivå innen idrettspsykologi, idrettspedagogikk og metodelære. Han er medlem av forskningsgruppa SEP-HEP (Sport and Exercise Psychology: Health, Education and Performance) og leder forskningsprosjektene Toppdommerrollen i fotball og Mestringstro hos toppdommere i håndball og fotball.

Urban Johnson (urban.johnson@hh.se) arbetar som professor i psykologi inriktning idrott vid Högskolan i Halmstad (HH). Han har en Fil. Dr. examen i tillämpad psykologi från 1997 vid Lunds Universitet och är en internationellt aktiv forskare inom området "idrottsskadans psykologi". Förutom forskningsledarroll på HH har han idag flera nationella uppdrag, t ex medlem i Svenska Fotbollsförbundets medicinska kommitte samt Centrum för Idrottsforskning.

Anders Meland (anders.meland@flymed.uio.no) er forsker og spesialist på mindfulness og menneskelige faktorer ved Flymedisinsk institutt, der han er rådgiver for militært flyoperativt personell i sikkerhetsarbeid og prestasjonsutvikling. Meland har en ph.d.-grad fra Norges idrettshøgskole (Tittel: Mindfulness in high performance environments), og har skrevet boken «Stillhetens råskap - mindfulness for å prestere på topp» (Cappelen Damm). Han er norsk medlem i NATO Science \& Technology, Panel for Human Factors and Medicine, og jobber deltid ved avdeling for idrettspsykologi ved Olympiatoppen. 
Yngvar Ommundsen (yngvar.ommundsen@nih.no) er utdannet allmennlærer fra Kristiansand lærerhøgskole 1975, med faglærerutdanning i kroppsøving 1977 og hovedfag 1979 i idrettsvitenskap ved Norges idrettshøgskole. Han har en ph.d.-grad i idrettsvitenskap fra samme sted 1992. Han er professor i idretts- og helsepsykologi ved Norges idrettshøgskole og professor II ved Universitetet i Agder - med vekt på undervisning, forskning og veiledning innen motivasjonspsykologi, atferdsendring samt barn og unges kognitive og psykologiske utbytte av deltakelse i idrett og fysisk aktivitet.

Anne Marte Pensgaard (anne.marte.pensgaard@nih.no) er professor i idrettspsykologi og forsker spesielt på temaene motivasjon, stress, mental helse og skader i toppidretten. Hun har skrevet flere bøker om relaterte tema samt produsert filmer og lydspor. Pensgaard har vært en sentral aktør i utviklingen av idrettspsykologiavdelingen ved Olympiatoppen, og er i dag ansvarlig for FoU og idrettspsykologi, i tillegg til at hun jobber med utvalgte forbund.

Michael S. Reinboth (michael.reinboth@usn.no) har en ph.d.-grad innen idretts-/helsepsykologi fra Universitetet i Birmingham i England. Han er ansatt som førsteamanuensis innen idrettsvitenskap som underviser, forsker og veileder ved Universitetet i Sørøst-Norge, Campus Bø. Hans forskningsinteresser ligger innenfor temaene motivasjon, prestasjonspsykologi, læringsmiljø og psykisk helse.

Knud Ryom (knudryom@ph.au.dk) er uddannet cand scient idræt fra Københavns Universitet (2011) og har en ph.d. også fra Københavns Universitet i 2017. Han er ansat som postdoc ved Institut for Folkesundhed, Aarhus Universitet. Han er formand for DIFO (Dansk Idrætspsykologisk Forum) og bestyrelsesmedlem i EMCC (European Mentoring and Coaching Counsil). Han arbejder også som sportspsykologisk konsulent og fungerer som ekspert for DGI i relation til idrætspsykologi.

Kjetil M.U. Salvesen (salvesen.kjetil@gmail.com) er utdannet idrettspedagog med bachelor- og mastergrad fra Universitetet i Agder (2016). Han 
har i flere år jobbet som underviser fra barneskolenivå opp til og med universitetsnivå. Nå jobber han som idrettspedagog ved Frisklivssentralen i Kristiansand kommune, som er et helsefremmende lavterskeltilbud med vekt på livsstilsendring gjennom gruppedeltakelse.

Sondre Risdal Solheim (sondre.solheim@hotmail.com) er utdannet idrettsviter, med en bachelorgrad fra Høgskolen i Telemark avd. Bø og en mastergrad fra Universitetet i Agder. Han har også praktisk-pedagogisk utdanning fra Norges idrettshøgskole. For tiden jobber han fulltid som personlig trener ved Studio Jobbsprek i Oslo, samtidig som han arbeider for Norges Triatlonforbund med trenerutvikling rundt unge utøvere. Ved siden av dette driver han også aktivt med triatlon.

Bård Erlend Solstad (b.e.solstad@nih.no) har en doktorgrad (ph.d.) i idrettsvitenskap, med spesialisering i idrettspsykologi fra Norges idrettshøgskole. Formålet med doktorgraden var å undersøke ulike aspekter ved trenerrollen i barne- og ungdomsfotball. Solstad er ansatt som postdoktor ved Forskningssenter for barne- og ungdomsidrett. I løpet av postdoktor-perioden arbeider Solstad med læringsklima, motivasjon og psykososialt utbytte av deltakelse i barne- og ungdomshåndball.

Reinhard Stelter (rstelter@nexs.ku.dk) er professor i idræts- og coachingpsykologi på Institut for Idræt og Ernæring, Københavns Universitet. Efteruddannelse i idrætspsykologi fra den Tyske Psykolog Akademi og akkred. coachingpsykolog i International Society for Coaching Psychology. Tidligere formand for Dansk Idrætspsykologisk Forum (1994-2004) og medlem i FEPSAC bestyrelsen (1999-2007). De sidste to årtier har Reinhard særligt arbejdet med udvikling af tredje generations coaching ${ }^{\oplus}$, som har ført til flere danske og udenlandske bogpublikationer og forskningsartikler.

Louise Kamuk Storm (lkstorm@health.sdu.dk) er cand.scient i idræt, Ph.D indenfor talentudvikling og sportspsykologi. Hun forsker og underviser i talentudvikling og sportspsykologi ved Syddansk Universitet i forskningsenheden LETS - Learning and Talent in Sport. Hendes forskning fokuserer på, hvordan kultur former karriereveje og 
talentudviklingsmiljøer. Hendes forskning er anvendelsesorienteret og derfor indgår hun i tæt samspil med trænere og ledere i praksis.

Anthony Wagstaff (Anthony.wagstaff@flymed.uio.no) er flylege og spesialist $\mathrm{i}$ arbeidsmedisin samt førsteamanuensis ved Institutt for helse og samfunn ved Universitetet i Oslo. Han har vært sentral i utviklingen av helse-, miljø- og sikkerhetsarbeid for flygende personell i Luftforsvaret og har en bred interesse innenfor flysikkerhet, flyoperativt arbeidsmiljø og optimalisering av funksjoner innenfor luftfarten. Han er president for European Society of Aerospace Medicine og styremedlem i International Academy of Aviation and Space Medicine.

Bente Wold (bente.wold@uib.no) er utdannet psykolog fra Universitetet i Bergen, med ph.d. fra samme sted i 1989. Hun arbeider med tverr- og flerfaglig forskning om helsefremmende arbeid blant barn og unge basert på teorier og metoder innen helse-, sosial- og utviklingspsykologi, atferdsepidemiologi og pedagogikk. 
